FERNANDO CÖRNER DA COSTA

\title{
GASES COMBUSTÍVEIS COMO ALTERNATIVAS À ELETROTERMIA EM AQUECIMENTO DIRETO E CALOR DE PROCESSO NO SETOR INDUSTRIAL BRASILEIRO
}

Tese apresentada ao Programa de Pós-Graduação em Energia da Universidade de São Paulo (Escola Politécnica / Faculdade de Economia e Administração / Instituto de Eletrotécnica e Energia / Instituto de Física) para obtenção do título de Doutor em Ciências em Energia.

Orientador: Prof. Dr. Murilo Tadeu Werneck Fagá

Versão corrigida

(versão original disponível na Biblioteca da Unidade que aloja o Programa e a Biblioteca Digital de Teses e Dissertações da USP)

SÃO PAULO

2013 
AUTORIZO A REPRODUÇÃO E DIVULGAÇÃO TOTAL OU PARCIAL DESTE TRABALHO, POR QUALQUER MEIO CONVENCIONAL OU ELETRÔNICO, PARA FINS DE ESTUDO E PESQUISA, DESDE QUE CITADA A FONTE.

FICHA CATALOGRÁFICA

Costa, Fernando Cörner da.

Gases combustíveis como alternativas à eletrotermia em aquecimento direto e calor de processo no setor industrial brasileiro./ Fernando Cörner da Costa; orientador : Murilo Tadeu Werneck Fagá. - São Paulo, 2013.

211 f.: il.; $30 \mathrm{~cm}$.

Tese (Doutorado - Programa de Pós-Graduação em Energia ) EP/FEA/IEE/IF da Universidade de São Paulo

1. Energia térmica. 2. Gases combustíveis . 3. Transferência de calor. Título 


\section{UNIVERSIDADE DE SÃO PAULO \\ PROGRAMA DE PÓS-GRADUAÇÃO EM ENERGIA \\ EP - FEA - IEE - IF}

\section{FERNANDO CÖRNER DA COSTA}

"Gases combustíveis como alternativas à eletrotermia em aquecimento direto e calor de processo no setor industrial brasileiro"

Tese defendida e aprovada pela Comissão Julgadora:

Prof. Dr. Murilo Tadeu Werneck Fagá - PPGE/USP

Orientador e Presidente da Comissão Julgadora

Prof. Dr. Edmilson Moutinho dos Santos - PPGE/USP

Prof. Dr. Antonio Gonçalves Mello Junior - MACKENZIE

Dr. Alberto José Fossa - MDJ/Consultoria

Prof. Dr. Eduardo Antonio Licco - SENAC 


\section{DEDICATÓRIA}

Em primeiro lugar dedico este trabalho a Deus, criador do universo e único detentor da verdade, aos meus pais, grandes incentivadores dos meus estudos, à minha querida esposa que sempre me apoia com carinho nas lutas por todos os objetivos, aos meus filhos e, agora, ao meu neto nascido há poucos dias, para que lhes sirva de exemplo a ser seguido. Este exemplo não se reduz à titulação obtida, mas sim à determinação em atingir objetivos positivos, honestos e saudáveis na vida, não importando a situação, as condições, nem a idade. 


\section{AGRADECIMENTOS}

Meu primeiro agradecimento não poderia deixar de ser ao Prof. Dr. Edmilson Moutinho dos Santos, quem me incentivou a fazer a pós-graduação e desenvolver esta pesquisa, quando ainda nem havia concluído meu mestrado.

Em continuação, agradeço intensamente ao incansável, competente e dedicado orientador, o Prof. Dr. Murilo Tadeu Werneck Fagá, pelo acompanhamento do desenvolvimento desta tese, conselhos e sugestões.

Aos professores e funcionários do IEE - Instituto de Eletrotécnica e Energia da USP, agora em transição para IEA - Instituto de Energia e Ambiente, pelos ensinamentos ministrados, atenção e respeito demonstrado para seus alunos.

À Cia. Ultragaz S.A., através das pessoas que representam a diretoria e as gerências, pelo pioneirismo que sempre norteou o rumo da empresa desde a sua fundação, possibilitando minha participação como funcionário e, posteriormente, como consultor no desenvolvimento de novas aplicações de GLP no mercado industrial, algumas delas citadas nesta tese.

Aos inúmeros ex-colegas e amigos da AGA S.A. - Brasil, da AGA-FANO colombiana e da matriz sueca AGA Aktiebolag, atualmente todas incorporadas à Linde, pelas inúmeras oportunidades de treinamento e desenvolvimento tanto no Brasil como no exterior, que também contribuíram para minha formação e proporcionaram a realização de experiências e concretizações, entre as quais existem algumas citações neste trabalho.

Aos engenheiros Denis Pinto Monteiro, Marcelo Cesar Palmieri, M.Sc., Gustavo Portas e William Carlos Becker Jr. pelas colaborações nesta pesquisa.

E, finalmente, às empresas que colaboraram com informações e ilustrações para esta tese, a saber: ATM Indústria e Comércio de Queimadores; ECAL Caldeiras e Aquecedores; PRB Combustão Industrial; e TEC - Tecnologia em Calor. 
"Fire is the best of servants; but what a master!"

Thomas Carlyle, 1843. 


\section{RESUMO}

COSTA, F. C. Gases combustíveis como alternativas à eletrotermia em aquecimento direto e calor de processo no setor industrial brasileiro, 2013, $211 \mathrm{f}$. Tese (Doutorado em Ciências) - Programa de Pós-Graduação em Energia da Universidade de São Paulo, São Paulo, 2013.

Este trabalho tem por objetivo analisar as perspectivas dos gases combustíveis como energia final para a obtenção de energia útil, em aquecimento direto (AD) e calor de processo (CP), identificando e quantificando potenciais como alternativa da eletrotermia. São comparados dois panoramas na avaliação das economias de energia primária pela substituição da eletrotermia: o primeiro considerando que a energia substituída oriunda de energéticos do parque gerador; e o segundo levando em conta que a redução se refletiu nas termelétricas. Para atingir este objetivo, o trabalho se inicia com uma revisão bibliográfica, onde são tratados os aspectos necessários para um melhor entendimento do texto, com os conceitos de eletrotermia, calor e termodinâmica, seguindo-se um capítulo destinado aos gases combustíveis, suas características e disponibilidade futura para a conversão. As informações básicas para a análise dos potenciais nos setores foram tomadas a partir do último Balanço de Energia Útil, além de trabalhos desenvolvidos no mercado industrial pelo autor. O trabalho discorre também sobre configurações tecnológicas usadas nas conversões, incluindo os custos envolvidos. $\mathrm{Na}$ conclusão, os cálculos mostraram que significativas economias de energia primária podem ser obtidas com a conversão da eletrotermia para gases combustíveis no setor industrial brasileiro, considerando a eletricidade produzida a partir de plantas termelétricas.

Palavras-chave: eletrotermia, gases combustíveis, energia térmica, aquecimento direto e calor de processo. 


\begin{abstract}
COSTA, F. C. Fuel gases as alternatives to electrothermy in direct heating and process heat in the Brazilian industrial sector, 2013. $211 \mathrm{f}$. Doctor's Thesis - Graduate Program on Energy, Universidade de São Paulo, São Paulo, 2013.
\end{abstract}

This paper aims to analyze the prospects of fuel gases as final energy in order to get useful energy in direct heating and process heat, identifying and qualifying potentials as the alternative of electrothermy. Two panoramas are compared in the evaluation of primary energy displacement: the first one considering the replaced energy coming from energy generating facilities and the second taking into account that the reduction was reflected in thermoelectric power plants. To achieve this goal, the work begins with a literature review which covers the aspects needed for a better understanding of the text, with the concepts of electrothermy, heat and thermodynamics, followed by a chapter intended for fuel gases, their characteristics and future readiness for conversion. The basic information for the analysis of potential sectors were taken for the last Useful Energy Balance, and work undertaken by the author in the industrial market. The paper also discourses about technological configurations used in conversions, including also the costs involved. In conclusion, the calculations showed that significant primary energy savings can be obtained through the conversion of electrothermy by fuel gases in the Brazilian industrial sector, taking into account the electricity produced from thermoelectric power plants.

Keywords: electrothermy, fuel gases, thermal energy, direct heating and process heat. 


\section{LISTA DE FIGURAS}

Figura 1 - Valores para o barril de petróleo de 1940 a 2012 ........................................ 22

Figura 2 - Produção e consumo de petróleo de 1970 a 2011 ......................................... 23

Figura 3 - Geração térmica anual-média dos 2000 cenários simulados ...................... 24

Figura 4 - Perfis de consumo eletrotérmico em situações extremas ............................. 31

Figura 5 - Perfil de consumo eletrotérmico conservador ......................................... 32

Figura 6 - Exemplo de sistema termodinâmico fechado .............................................. 44

Figura 7 - Exemplo de sistema aberto - forno de calcinação ..................................... 44

Figura 8 - Geradora de vapor saturado a gás natural ............................................... 46

Figura 9 - Exemplo de diagrama de Sankey para geradoras de vapor .......................... 47

Figura 10 - Fluxo de massa e energia em sistema aberto e volume de controle .............. 52

Figura 11 - Eficiências da combustão do GN em função da temperatura ......................... 55

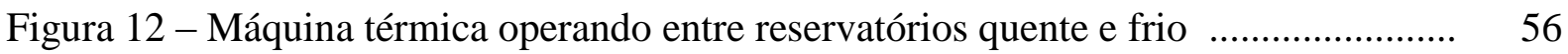

Figura 13 - Balanço de gás natural no Brasil - malha integrada .................................. 62

Figura 14 - Projeção do balanço de gás natural para a região norte ............................... 63

Figura 15 - Importações de GLP, de 2000 a 2012 ....................................................... 66

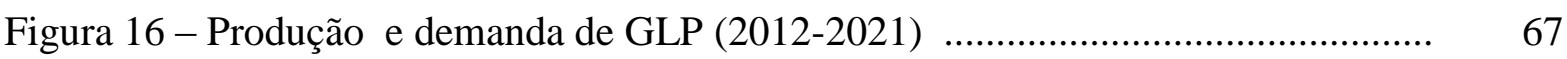

Figura 17 - Market share do mercado de GLP em janeiro de 2013 ............................... 69

Figura 18 - Queimador monobloco a gás ................................................................. 85

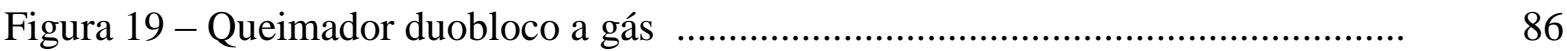

Figura 20 - Instalações de queimadores de duto ......................................................... 88

Figura 21 - Queimadores de duto ........................................................................... 88

Figura 22 - Queimador infravermelho ............................................................... 89

Figura 23 - Queimador oxigênio-gás natural ……...................................................... 92

Figura 24 - Algoritmo para determinação da energia equivalente na conversão para gás. 96

Figura 25 - Consumo de energéticos na indústria de cimento ....................................... 100

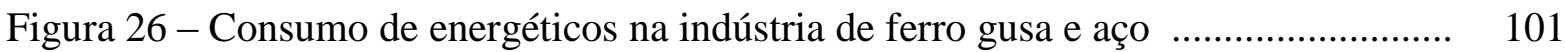

Figura 27 - Tempos de fusão em FEA com e sem queimadores auxiliares ................... 104

Figura 28 - Calor contido na sucata de aço em função da temperatura ......................... 106

Figura 29 - Esquema do queimador oxi-gás em forno de indução ................................ 109

Figura 30 - Queimador móvel operando em FEA ...................................................... 110 
Figura 31 - Consumo de energéticos na indústria de química

Figura 32 - Aquecedor instantâneo de óleo térmico a GLP

Figura 33 - Eficiência dos ciclos termodinâmicos 150

Figura 34 - Equivalência GN - energia elétrica 162

Figura 35 - Equivalência GLP - energia elétrica 162

Figura 36 - Curva de preços para queimadores monobloco para GN 166

Figura 37 - Curva de preços para queimadores monobloco para GLP 167

Figura 38 - Curva de preços para queimadores duobloco para GN 168

Figura 39 - Curva de preços para queimadores duobloco para GLP 169

Figura 40 - Preços de caldeiras flamotubulares a vapor saturado 170

Figura 41 - Tipo de chama convencional 183

Figura 42 - Tipo de chama headpin 183

Figura 43 - Tipo de chama esférica 184

Figura 44 - Tipo de chama cônica 184

Figura 45 - Tipo de chama plana 185

Figura 46 - Chama longa, luminosa e flácida 185

Figura 47 - Chama longa, luminosa e firme 185

Figura 48 - Chama de alta velocidade 186 


\section{LISTA DE TABELAS}

Tabela 1 - Relação entre PCI e PCS dos gases combustíveis .................................... 37

Tabela 2 - Especificações do gás natural no Brasil ....................................................... 61

Tabela 3 - Comparação das características do GN, GLP e GNS ................................. 70

Tabela 4 - Composição do gás de coqueria ............................................................... 72

Tabela 5 - Composição do gás de alto forno .............................................................. 72

Tabela 6 - Composição do GR disponível para ampliação da PQU ............................ 74

Tabela 7 - Números de cetano dos óleos diesel e do DME ...................................... 75

Tabela 8 - Temperaturas mínimas de autoignição ……............................................ 84

Tabela 9 - Temperaturas adiabáticas de chama ............................................................. 90

Tabela 10 - Volumes específicos de produtos da combustão .......................................... 90

Tabela 11 - Rendimentos de fornos elétricos .............................................................. 97

Tabela 12 - Rendimentos de fornos a combustíveis gasosos ....................................... 98

Tabela 13 - Produção anual das fundições de ferro e aço ............................................ 108

Tabela 14 - Substituição de eletrotermia em AD na indústria de ferro-ligas .................. 113

Tabela 15 - Substituição de eletrotermia em AD na indústria de mineração .................. 114

Tabela 16 - Substituição de eletrotermia em AD na indústria de pelotização ................. 116

Tabela 17 - Substituição de eletrotermia em AD na indústria de alumínio .................... 117

Tabela 18 - Substituição de eletrotermia em AD na indústria de outros produtos

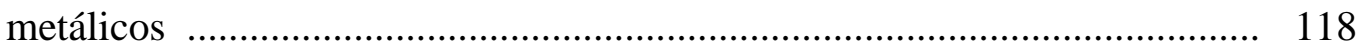

Tabela 19 - Substituição de eletrotermia em AD na indústria química $\quad$........................... 120

Tabela 20 - Substituição de eletrotermia em AD na indústria de alimentos e bebidas excluindo açúcar ........................................................................... 122

Tabela 21 - Substituição de eletrotermia em AD na indústria de cerâmica .................... 126

Tabela 22 - Substituição de eletrotermia em AD em outros setores da indústria ........... 128

Tabela 23 - Potencial de substituição da eletrotermia em aquecimento direto ............... 129

Tabela 24 - Potencial para gases combustíveis substitutos em aquecimento direto ........ 130

Tabela 25 - Rendimento por setores de aplicação em calor de processo ....................... 136

Tabela 26 - Substituição de eletrotermia em CP na indústria de ferro gusa e aço .......... 137

Tabela 27 - Substituição de eletrotermia em CP na indústria de mineração .................. 138

Tabela 28 - Substituição de eletrotermia em CP na indústria de alumínio .................... 138 
Tabela 29 - Substituição de eletrotermia em CP na indústria química

Tabela 30 - Substituição de eletrotermia em CP na indústria de alimentos e bebidas excluindo açúcar

Tabela 31 - Substituição de eletrotermia em CP na indústria de papel e celulose 142

Tabela 32 - Substituição de eletrotermia em CP em outros setores da indústria 145

Tabela 33 - Potencial de substituição da eletrotermia em calor de processo 146

Tabela 34 - Potencial para gases combustíveis substitutos em calor de processo 147

Tabela 35 - Potencial para as energias finais 148

Tabela 36 - Centrais termelétricas de serviço público - 2008 / 2012 151

Tabela 37 - Centrais termelétricas autoprodutoras - 2008 / 2012 151

Tabela 38 - Conversão de combustíveis consumidos em energia primária nas termelétricas de serviço público

Tabela 39 - Conversão de combustíveis consumidos em energia primária nas termelétricas autoprodutoras

Tabela 40 - Comparação das conversões de energia final em energia primária 157

Tabela 41 - Equivalência GN - energia elétrica 187

Tabela 42 - Equivalência GLP - energia elétrica 188 


\section{LISTA DE ABREVIATURAS E SIGLAS}

ABB Asea Brown Boveri (denominação antiga)

ABIFA Associação Brasileira de Fundição

ABIQUIM Associação Brasileira da Indústria Química

ABNT Associação Brasileira de Normas Técnicas

ABTCP Associação Brasileira Técnica de Celulose e Papel

ANEEL Agência Nacional de Energia Elétrica

ANP Agência Nacional do Petróleo, Gás Natural e Biocombustíveis

ASU Air Separation Unit

BEN Balanço Energético Nacional

BEU Balanço de Energia Útil

BFG Blast Furnace Gas

BOF Basic Oxygen Furnace

BP British Petroleum

BPF $\quad$ Baixo ponto de fluidez

BTU British Thermal Unit

$\mathrm{C5}^{+} \quad$ Hidrocarbonetos com 5 ou mais átomos de carbono

CB-09 Comitê Brasileiro de Gases Combustíveis

CERNE Centro de Excelência em Recursos Naturais e Energia

CFC Clorofluorcarbono

CGTEE Companhia de Geração Térmica de Energia Elétrica

CHP Combined Heat and Power

CNAE Classificação Nacional de Atividades Econômicas

CNP Conselho Nacional do Petróleo

COG Coke Oven Gas

COV Componente Orgânico Volátil

CRM Conjunto de Regulagem e Medição

CST Companhia Siderúrgica de Tubarão

DME Dimetil Éter

E\&P Exploração \& Produção (Exploration \& Production)

EGTD Energia Garantida por Tempo Determinado 
EPE Empresa de Pesquisa Energética

FDTE Fundação para o Desenvolvimento Tecnológico da Engenharia

FEA Forno Elétrico a Arco

FEC Fuel and Energy Consultants Ltd.

FISPQ Ficha de Informação de Segurança de Produto Químico

GAF Gás de Alto Forno

GASBOL Gasoduto Brasil-Bolívia

GEE Gases de Efeito Estufa

GHG Greenhouse Gases

GLP Gás Liquefeito de Petróleo

GN Gás Natural

GNB Gás Natural da Bolívia

GNC Gás Natural Comprimido

GNL Gás Natural Liquefeito

GNS Gás Natural Sintético

GR Gás de Refinaria

GWP Global Warming Potential

IDA International DME Association

IEA International Energy Agency

IFRF Internacional Flame Research Foundation

INCA Indústria Cerâmica da Amazônia

INMETRO Instituto Nacional de Metrologia, Qualidade e Tecnologia

INT Instituto Nacional de Tecnologia

LFG Landfill Gas

LNG Líquidos do Gás Natural

MCTI Ministério da Ciência, Tecnologia e Inovação

MMBTU Milhão de BTUs

MME Ministério de Minas e Energia

MP Material Particulado

NBR Norma Brasileira

OC Óleo Combustível

OECD Organisation for Economic Co-operation and Development

ONS Operador Nacional do Sistema Elétrico 
PCI Poder Calorífico Inferior

PCS Poder Calorífico Superior

PDE Plano Decenal de Expansão de Energia

PLC Programmable Logic Controller

PNE Plano Nacional de Energia

PQU Petroquímica União, posteriormente Quattor e Braskem

PSA Pressure Swing Adsorption

PROCEL Programa Nacional de Conservação de Energia Elétrica

REVAP Refinaria do Vale do Paraíba ou Refinaria Henrique Lage (atual)

SGM Secretaria de Geologia, Mineração e Transformação Mineral

SIGEA Sistema de Gestão de Emissões Atmosféricas

SINDIGÁS Sindicato Nacional da Empresas Distribuidoras de GLP

tep Toneladas equivalentes de petróleo

UPGN Unidade de Processamento de Gás Natural

US\$ Dólar norte-americano

VOC Volatile Organic Compound

VPSA Vacuum pressure swing adsorption

WLPGA World LP Gas Association

WTI West Texas Intermediate 


\section{SUMÁRIO}

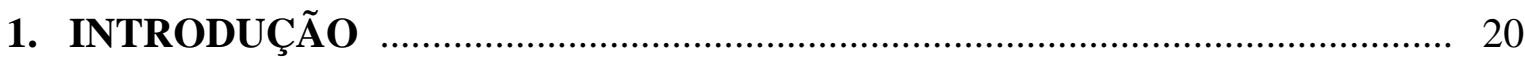

1.1 Panorama energético brasileiro ......................................................................... 21

1.2 Relevância da pesquisa ……………………………………………………... 25

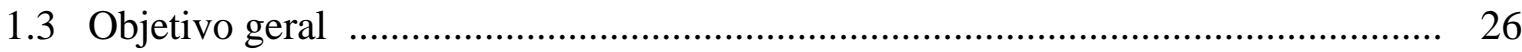

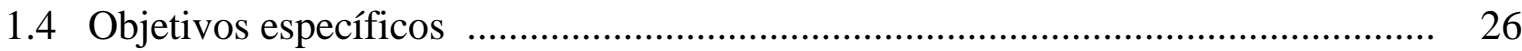

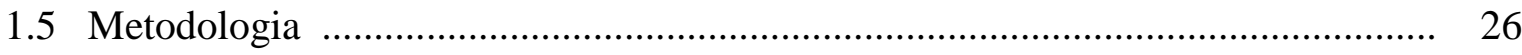

1.6 Estrutura do trabalho ................................................................................... 27

2. CONCEITOS FUNDAMENTAIS _............................................................. 29

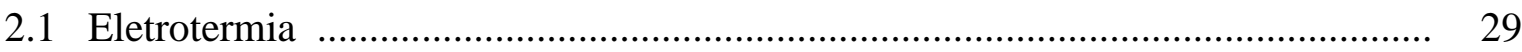

2.1.1 Ambiente tarifário ………………………………............................... 30

2.1.2 Potência dos equipamentos eletrotérmicos ………………………………..... 31

2.1.3 Potência e produtividade ……………………………………………….... 32

2.1.4 Modalidades de conversão …………………………………………………... 33

2.1.4.1 Substituição total da eletrotermia ................................................................. 33

2.1.4.2 Substituição parcial da eletrotermia ………………………………………... 34

2.2 Geração de calor com gases combustíveis ……………………………………... 35

2.3 Calor como energia útil ……………………………………………….... 39

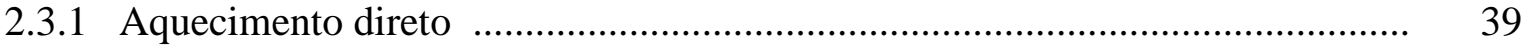

2.3.2 Calor de processo ........................................................................................ 42

2.4 Termodinâmica ………………………………………………………...... 43

2.4.1 Sistemas termodinâmicos e volume de controle ................................................ 43

2.4.2 Lei zero da termodinâmica ……………………………………………... 45

2.4.3 Primeira lei da termodinâmica ……………………………………………... 45

2.4.3.1 Aspectos da conservação da energia ........................................................... 45

2.4.3.2 Balanço de massa e energia ………………………………………….... 48

2.4.3.3 Aspectos de calor e trabalho .................................................................... 50

2.4.3.4 Energia e eficiência energética ……………………………………….... 51

2.4.4 Segunda lei da termodinâmica …………………………………………….. 55

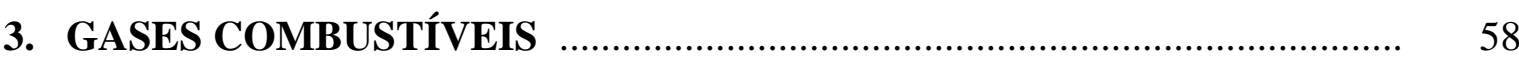

3.1 Famílias de gases combustíveis ..................................................................... 58 


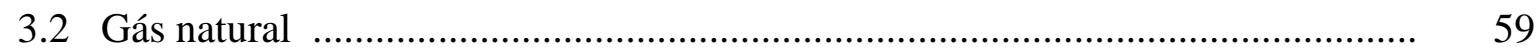

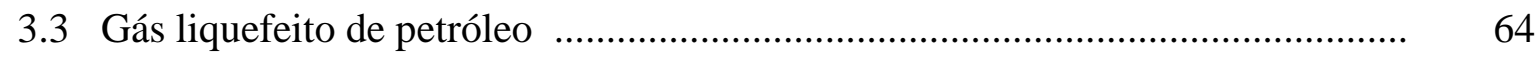

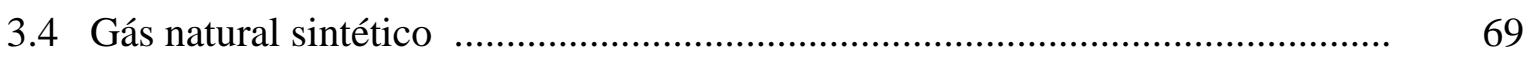

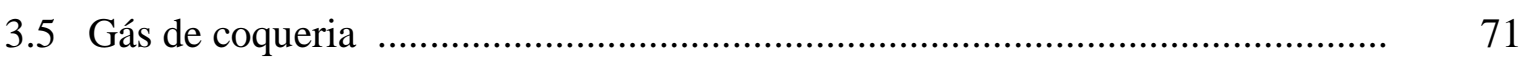

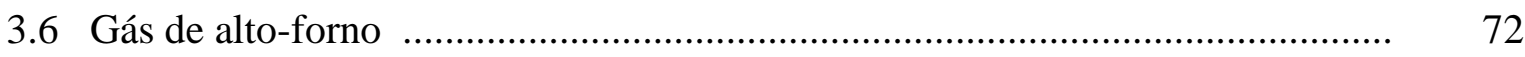

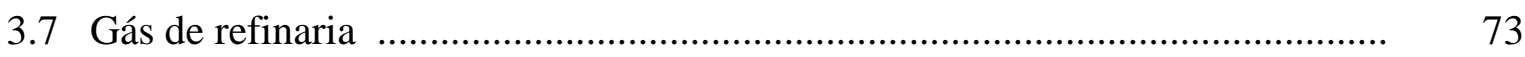

3.8 Gás de biodigestão anaeróbica …………………………………………......

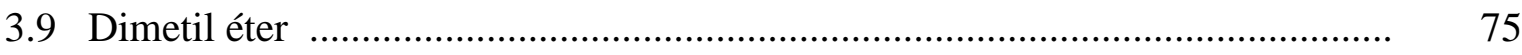

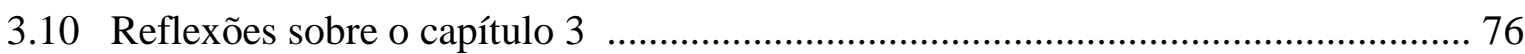

4. ASPECTOS TECNOLÓGICOS NA TRANSFORMAÇÃO DE GASES COMBUSTÍVEIS EM CALOR .....................................................................

4.1 Aplicações da chama direta ……………………………………………........ $\quad$.. $\quad 79$

4.2 Aplicações da chama parcialmente confinada ……………………………......

4.3 Aplicações da chama indireta ou confinada ………………………………........

4.4 Tipos de queimadores a gás …………………………………………….....

4.4.1 Classificação dos queimadores ……………………………………....... $\quad$... 81

4.4.2 Adequação dos queimadores às temperaturas de processo ............................. 83

4.4.2.1 Queimadores monobloco ......................................................................... $\quad$.. 83

4.4.2.2 Queimadores duobloco …………………………………………..... $\quad \ldots \quad 86$

4.4.2.3 Queimadores de duto .......................................................................... $\quad$... 87

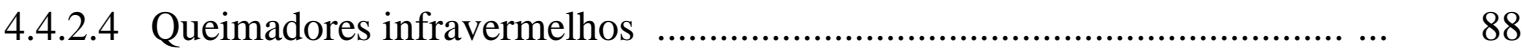

4.4.2.5 Queimadores oxigênio-gás …………………………………………....... $\quad 89$

4.4.3 Modalidades operacionais dos queimadores …………………………..... 92

4.4.3.1 Queimadores de único estágio …………………………………………..... 92

4.4.3.2 Queimadores de dois estágios …………………………………………....... 93

4.4.3.3 Queimadores modulantes …………………………………………….... 93

4.4.4 Configurações de chama ………………………………………………..... $\quad$.. 94

4.5 Reflexões sobre o capítulo 4 ...................................................................... $\quad \ldots$

5. ALTERNATIVAS PARA A SUBSTITUIÇÃO DA ELETROTERMIA NO AQUECIMENTO DIRETO _........................................................................ 96

5.1 Rendimentos energéticos em AD ………………………………………....... 97

5.2 Potenciais de substituição da eletrotermia em AD por setor industrial …….... 98

5.2.1 Indústria de cimento ..................................................................................... 99 


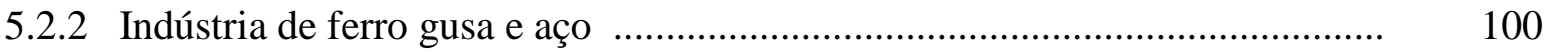

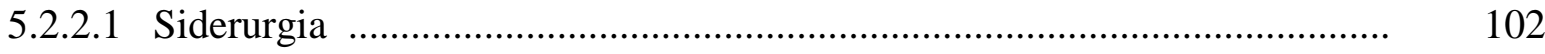

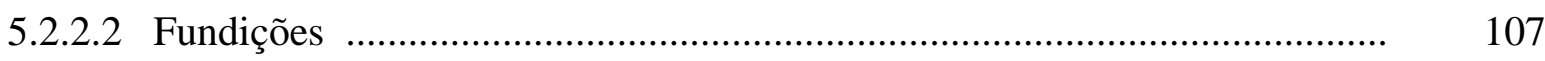

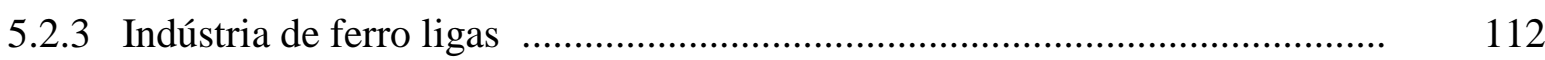

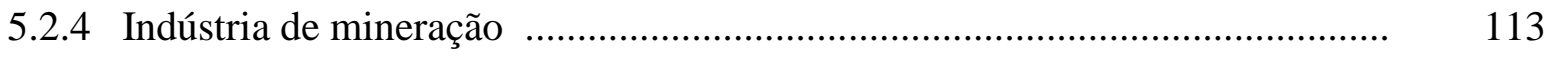

5.2.5 Indústria de pelotização .......................................................................... 115

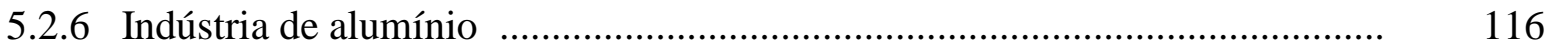

5.2.7 Indústria de outros produtos metálicos ....................................................... 117

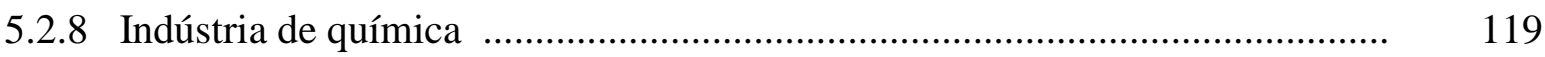

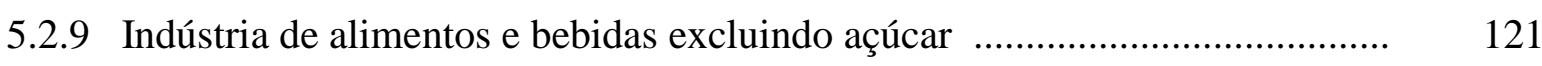

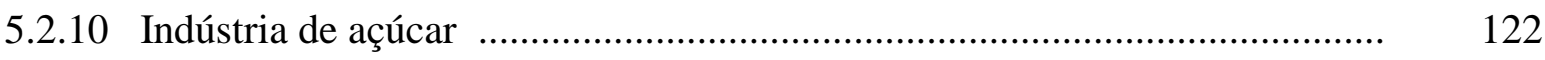

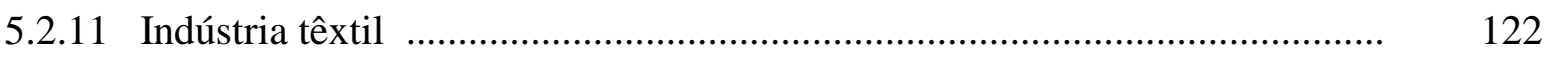

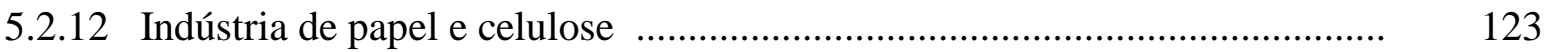

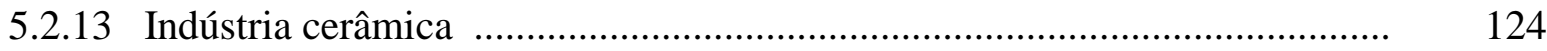

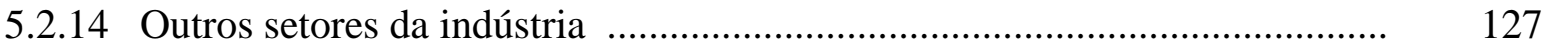

5.3 Potencial total para substituição de eletrotermia em aquecimento direto .......... 128

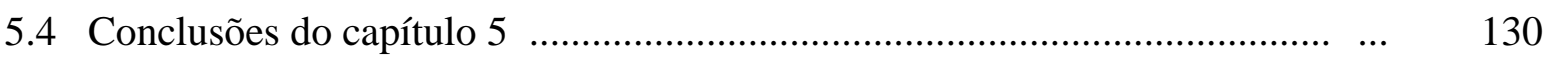

6. ALTERNATIVAS PARA A SUBSTITUIÇÃO DA ELETROTERMIA NO CALOR DE PROCESSO …................................................................. 131

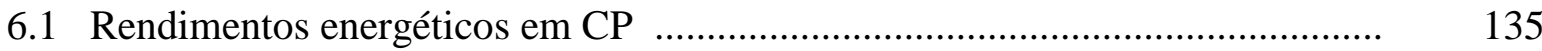

6.2 Potenciais de substituição da eletrotermia em CP por setor industrial ............. 136

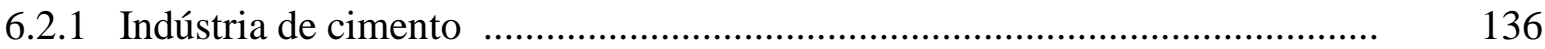

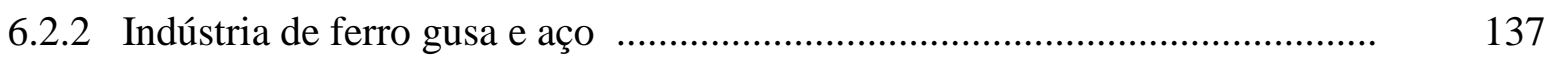

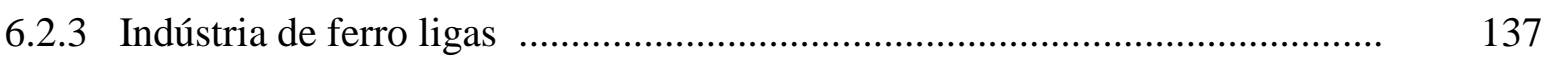

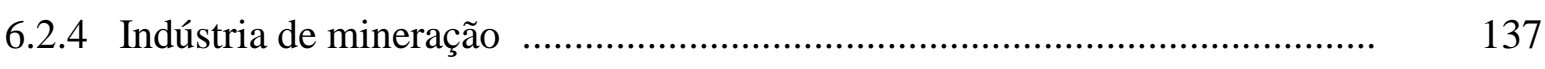

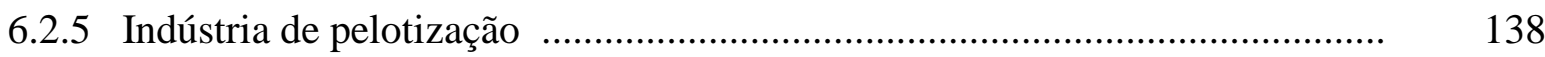

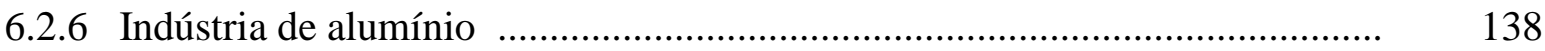

6.2.7 Indústria de outros produtos metálicos ........................................................ 138

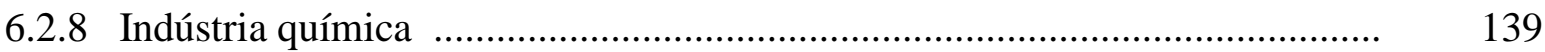

6.2.9 Indústria de alimentos e bebidas excluindo açúcar ..................................... 140

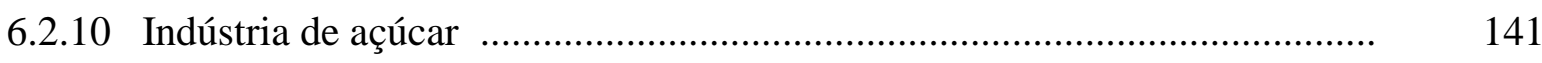

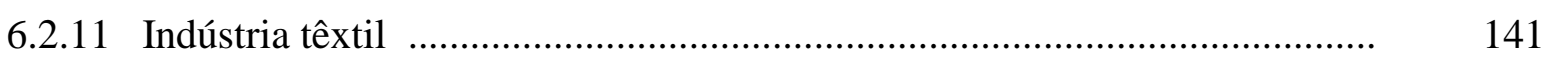

6.2.12 Indústria de papel e celulose ................................................................ 142 


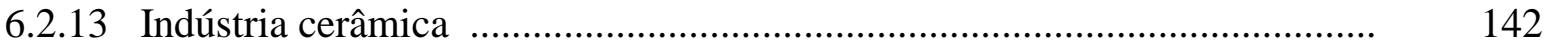

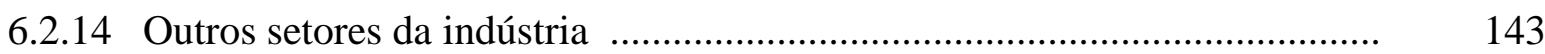

6.3 Potencial total para substituição de eletrotermia em calor de processo ........... 146

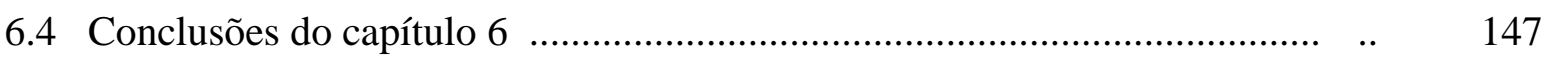

7. REDUÇÃO NO CONSUMO DE ENERGIA PRIMÁRIA PELA SUBSTITUIÇÃO DE ELETROTERMIA …............................................ 148

7.1 Consolidação dos potenciais estimados …….................................................. 148

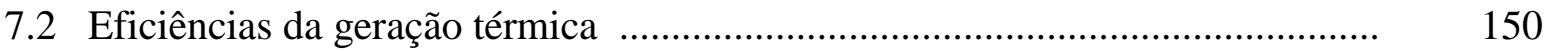

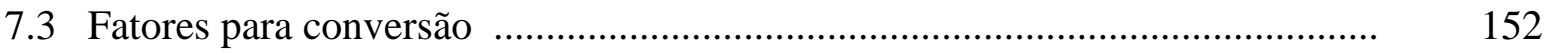

7.3.1 Fator da extração, processamento e transporte de combustíveis .................. 152

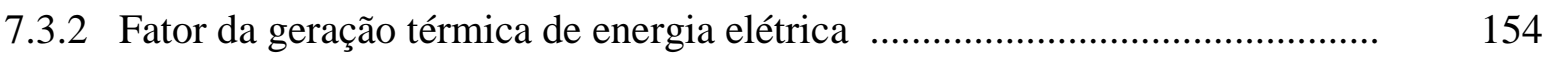

7.3.3 Fator da transmissão e distribuição de energia elétrica ................................. 155

7.4 Comparação da substituição da eletrotermia por GN e GLP .............................. 156

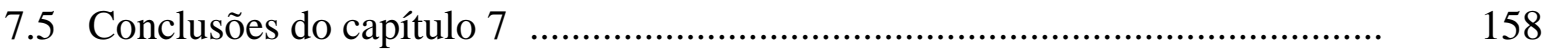

8. ASPECTOS ECONÔMICOS NA SUBSTITUIÇÃO DA ELETROTERMIA 159

8.1 Equivalência econômica gás $\mathrm{x}$ eletricidade ........................................................ 159

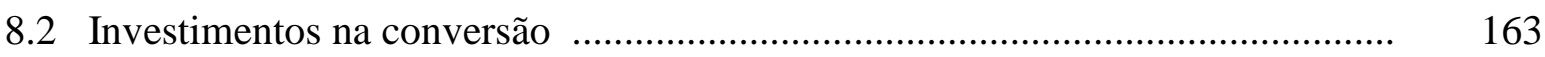

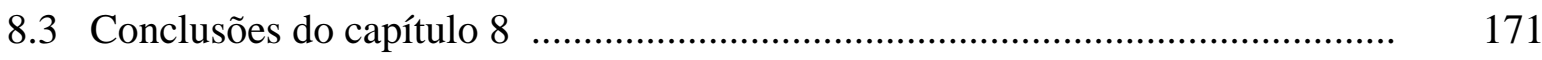

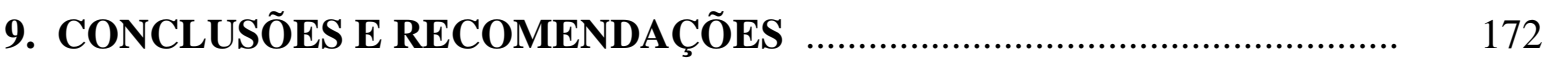

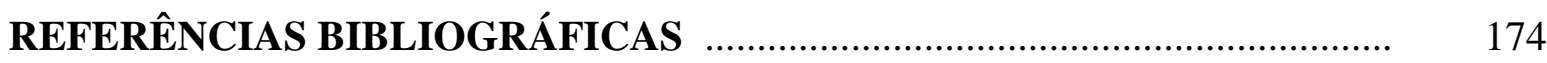

APÊNDICE A - Consumos específicos de eletricidade na produção de oxigênio .. 181

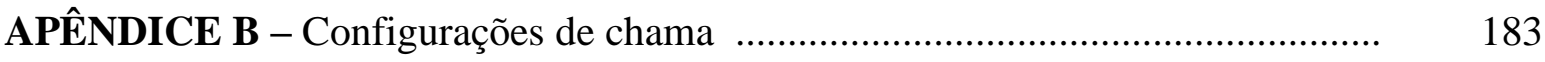

APÊNDICE C - Equivalência GN - energia elétrica ........................................... 187

APÊNDICE D - Equivalência GLP - energia elétrica ........................................ 188

ANEXO A - Instrução Normativa CNP / DIPLAN No 01/84 - Pesquisa de

Consumo de Energia .................................................................... 189 


\section{INTRODUÇÃO}

Energia é uma palavra que pode representar uma ampla gama de conceitos, sendo sua principal forma de expressão a capacidade de um sistema para gerar calor e trabalho.

Desde os primórdios da evolução do nosso planeta, a energia ofertada pela natureza teve um papel fundamental na criação de todas as formas de vida e desenvolvimento das espécies, dos mais elementares organismos até o estágio atual da raça humana. A principal fonte de calor, durante todo esse processo, tem sido a energia solar associada às suas formas de absorção, mecanismos de transmissão e de armazenagem de calor na biosfera. Todos os seres vivos, animais e vegetais, dependem em maior ou menor escala, da manutenção da sua cadeia alimentar e da temperatura do seu habitat, resultado de um complexo sistema interrelacionando fenômenos físicos, químicos e biológicos.

A partir do momento que o homem primitivo começou a utilizar o fogo para aquecimento e cocção e, posteriormente, a tração animal durante milhares de anos, a demanda energética sob a forma de biomassa era sustentável e o impacto ambiental global de sua utilização poderia ser considerado desprezível.

Desde a antiguidade, os povos vêm desmatando as florestas para utilizar a madeira como energia e matéria-prima. Conforme citado por Goldemberg e Villanueva (2003), o filósofo grego Platão, quatro séculos antes do início da era cristã, já lamentava a destruição das florestas que haviam coberto as montanhas da Grécia séculos antes, deixando-as estéreis. $\mathrm{Na}$ narrativa de Fagan (2008), a devastação das florestas na Europa talvez tenha sido superior a $50 \%$ entre os anos 1100 e 1350 D.C.

No final do Século XX da era cristã, o planeta Terra começa a apresentar fortes indícios do esgotamento de seus recursos naturais e de sua capacidade de absorver a enorme quantidade de resíduos gerados pelas atividades humanas, causando impactos ambientais com abrangências local, regional e global.

A crescente demanda de energia primária, necessária para abastecer um planeta com mais de sete bilhões de habitantes, duplicou no período de 1973 a 2010 e é responsável pela incessante busca de fontes energéticas. Considerando o suprimento mundial de 12.717 milhões de toneladas equivalentes de petróleo (tep), apenas 8.677 milhões de tep são utilizadas pelos usuários finais, segundo a IEA (2012), sendo a diferença utilizada principalmente nos processos de conversão da energia primária em vetores energéticos, como refino do petróleo, processamento do gás natural, geração de energia elétrica, transporte, distribuição etc. 
Consequentemente, as emissões de dióxido de carbono $\left(\mathrm{CO}_{2}\right)$ se elevaram no citado período quase na mesma proporção do suprimento total de energia primária. Embora contestado por alguns pesquisadores, o aquecimento global e as mudanças climáticas apresentam uma inequívoca relação com a emissão de gases de efeito estufa (GEE).

Neste panorama, onde se torna difícil traçar o caminho para a raça humana em contínuo crescimento, se enquadra este trabalho que tem por objetivo apresentar algumas perspectivas para minorar, ainda que modestamente, as emissões dos gases de efeito estufa através da redução da demanda específica de energia primária.

\subsection{Panorama energético brasileiro}

A partir da década dos anos 70, os preços mundiais do petróleo afetaram significativamente o panorama energético brasileiro.

A primeira crise mundial do petróleo devido ao embargo árabe, em 1973, foi a primeira advertência de que o petróleo quebraria o paradigma de tratar-se de uma fonte primária de energia barata e inesgotável no curto prazo. Após décadas de estabilidade com os preços abaixo do patamar de 20 dólares americanos por barril, os preços se elevaram para 50 dólares americanos (ambos os valores corrigidos monetariamente para o dólar de 2012), conforme Figura 1.

Após a segunda crise do petróleo devido à Revolução Iraniana, em 1979, e a Guerra IrãIraque, em 1980, o Brasil se encontrava em uma situação muito desfavorável, com o preço do barril de petróleo atingindo valores próximos a 100 dólares (Figura 1). A importação de petróleo significava cerca de $80 \%$ das necessidades do país (Figura 2) e a balança de pagamentos era deficitária, aumentando a dívida externa.

Ambas as crises aceleraram a busca por fontes de energia primária de origem nacional, como a prospecção de petróleo, o Programa Nacional do Álcool e a construção de hidrelétricas de grande porte. Enquanto havia a imperiosa necessidade da redução do uso dos derivados do petróleo importado, passou a existir oferta da energia elétrica que, naquela ocasião, suplantava a demanda.

Consequentemente, estabeleceu-se um programa para incentivar a eletrotermia, ou seja, a utilização de energia elétrica para fins de geração de calor, conhecido por EGTD - Energia Garantida por Tempo Determinado. 


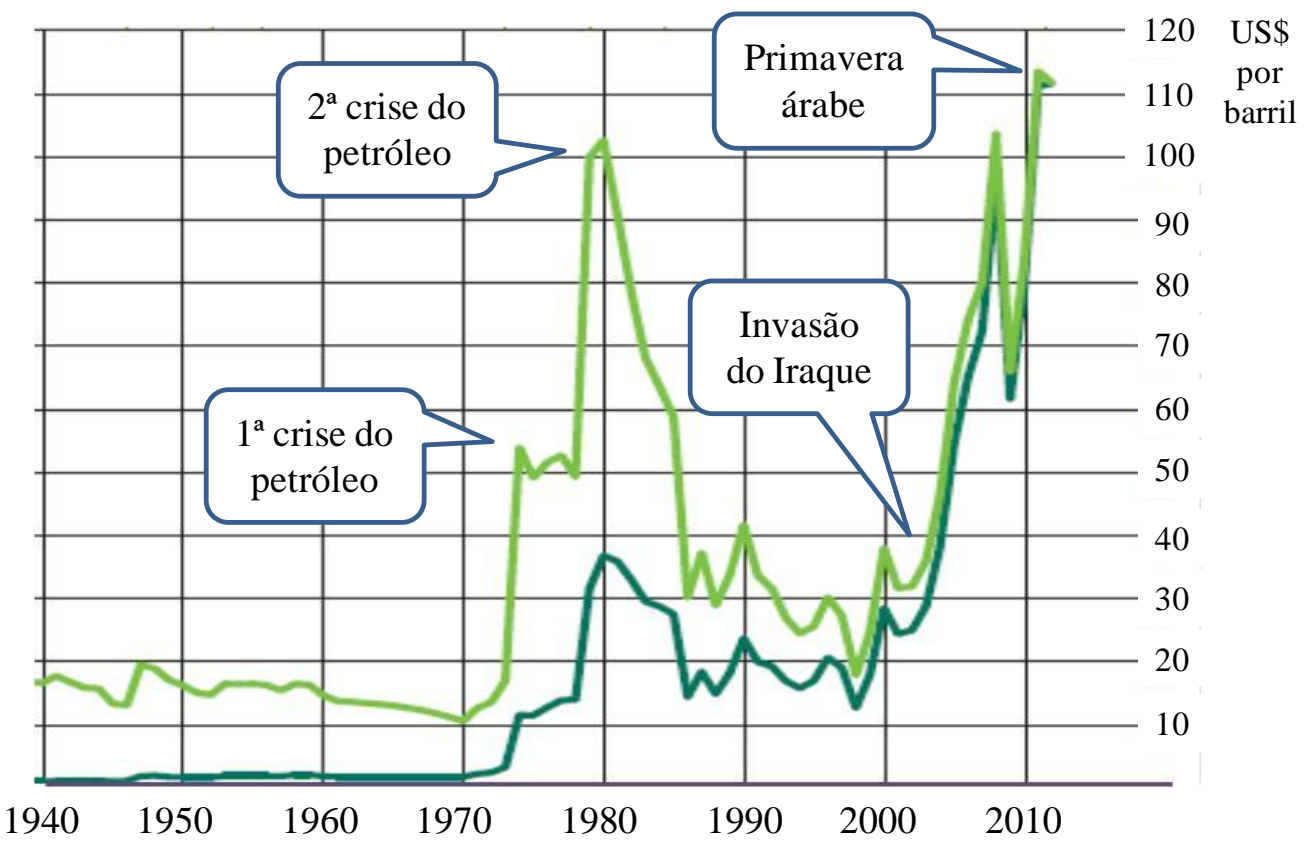

US\$ corrigido para 2012

US\$ nominal nas referidas datas

Figura 1 - Valores para o barril de petróleo de 1940 a $2012^{1}$

Fonte: elaboração própria a partir de British Petroleum (2013)

Este programa instituía uma tarifa da energia elétrica inferior em $30 \%$ ao equivalente energético do óleo combustível, de forma a viabilizar sua utilização e os investimentos na compra de equipamentos eletrotérmicos como fornos, secadores, estufas e caldeiras. Embora justificável no panorama da época, onde era prioritária a economia de divisas, o estabelecimento de uma cultura eletrotérmica no país não pode ser considerado como um fato positivo no médio e longo prazo. Assim, em meados da década dos anos 80, conforme citado por Nogueira (ELETROBRÁS/PROCEL, 2001, p. 98), “[...] a denominada crise do petróleo transmutou-se paulatinamente em crise do setor elétrico e desde então dificuldades de suprimento vêm ocorrendo de forma mais ou menos recorrente, impondo o exercício quase permanente da conservação de energia". Esta imposição culminou, em 1985, na instituição do PROCEL - Programa Nacional de Conservação de Energia Elétrica.

\footnotetext{
1 A metodologia utilizada para os preços do petróleo levou em conta as cotações do Brent, do West Texas Intermediate (WTI), Nigerian Focados e Dubai em dólares norte-americanos.
} 
E também, conforme citado por Santos (2002), “o avanço da termeletricidade a gás no Brasil conduzirá, em muitas situações, a um grau de irracionalidade energética, sem que os princípios de conservação e melhor utilização sejam atendidos".

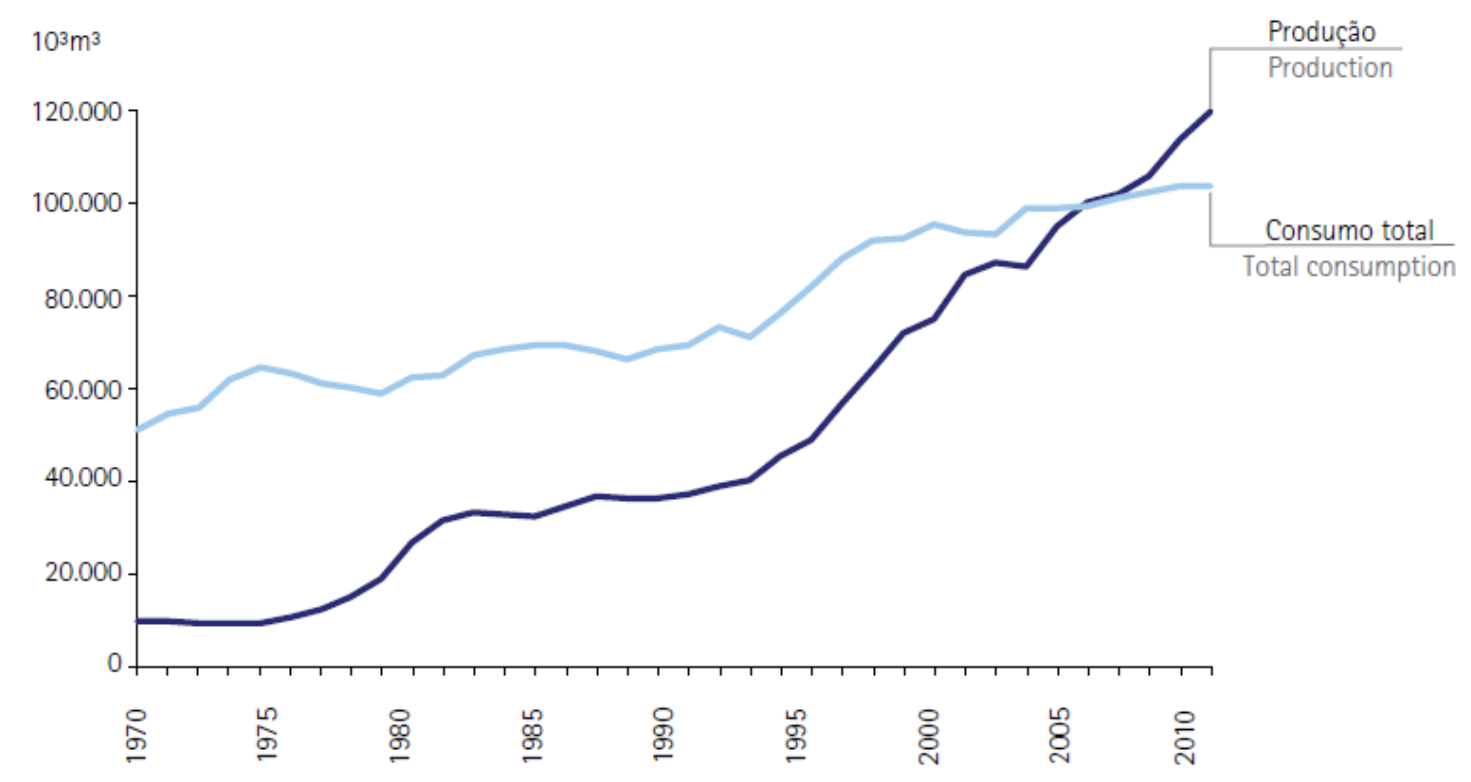

FIGURA 2 - Produção e consumo de petróleo de 1970 a 2011

Fonte: MME, BEN 2012

Posteriormente, outros eventos também afetaram os preços do petróleo como a Guerra do Golfo Pérsico em 1990, a invasão do Iraque e a crise internacional de 2008, com o preço do petróleo flutuando na faixa acima de 60 e abaixo de 120 dólares.

O contexto onde se insere esta tese é o panorama do sistema elétrico brasileiro, considerando a participação de usinas termelétricas como uma realidade atual e futura. O Plano Nacional de Energia 2030 (EPE/MME, 2007) previa um aumento na participação da geração térmica convencional de 7\% (2005) para 15\% em 2030, mesmo considerando um aumento expressivo na participação das fontes renováveis e da redução das perdas totais.

E o Plano Decenal de Expansão de Energia 2021 (EPE/MME, 2013), continua prevendo o uso de termelétricas, cuja expectativa dos despachos para atendimento energético por solicitação do Operador Nacional do Sistema Elétrico (ONS) é apresentada na Figura 3, onde se destaca a entrada em operação da usina nuclear Angra 3 e a significante participação do gás natural em contraposição com a insignificante expectativa para o óleo combustível e o óleo diesel. 


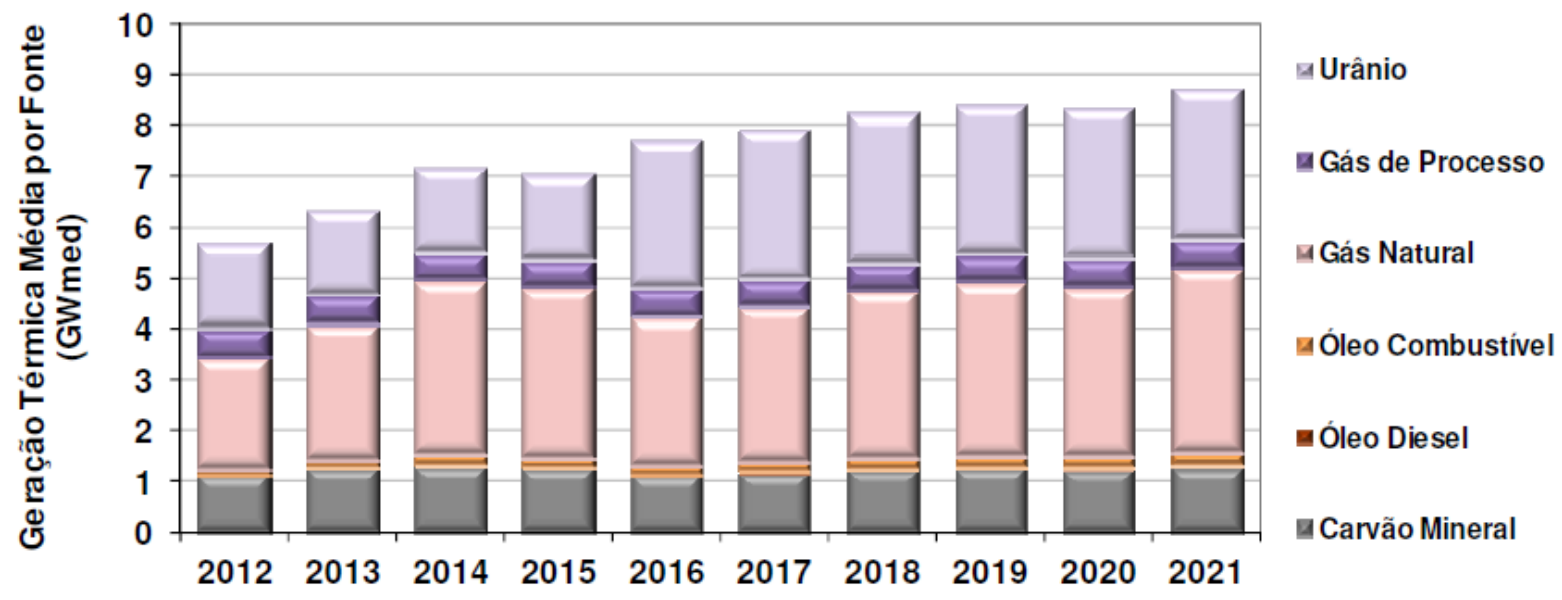

FIGURA 3 - Geração térmica anual - média dos 2000 cenários simulados

Fonte: EPE/MME, 2013

As usinas termelétricas no Brasil apresentam uma eficiência média estimada da ordem de 40\% segundo Strapasson e Fagá (2007), ou seja, 60\% da energia (gás natural, óleo combustível e carvão mineral) é perdida nos ciclos termodinâmicos dos processos de geração. Mesmo considerando que as termelétricas sejam instaladas próximas aos centros de demanda, não necessitando trafegar significativamente pelas extensas linhas de transmissão que cortam o país, apenas pouco mais de um terço da energia primária gerada chega efetivamente na porta dos consumidores. O custo da ineficiência energética deste processo de geração é elevado, devido à sua natureza dos fenômenos termodinâmicos envolvidos: quase dois terços da energia primária são perdidos para a atmosfera, colaborando para o aumento dos gases de efeito estufa e outros poluentes como material particulado, monóxido de carbono, hidrocarbonetos não queimados, óxidos de enxofre e óxidos de nitrogênio.

Sob este aspecto e como energéticos de transição entram em cena os gases combustíveis, principalmente gás natural (GN) e GLP, os quais apresentam inúmeras vantagens em relação aos óleos combustíveis e ao carvão mineral, como a menor emissão de gases de efeito estufa e outros poluentes, características estas que os permitem de serem chamados "ecologicamente amigáveis".

Portanto esta tese se justifica na medida em que as eficiências da cadeia dos gases combustíveis para produção de calor sejam superiores às eficiências da cadeia da energia elétrica para produção de calor (eletrotermia) com base na geração térmica, ambas relacionadas com os usos finais em processos térmicos industriais. O fato do enfoque nos gases combustíveis para substituição da eletrotermia, além do fato de serem considerados 
ambientalmente amigáveis, é a perspectiva de ampla oferta de gás natural e GLP no futuro próximo, devido à entrada em operação de novos sistemas de petróleo e gás natural com suas novas refinarias e UPGNs - Unidades de Processamento de Gás Natural, onde a exploração das jazidas do pré-sal se somarão às reservas do pós-sal.

\subsection{Relevância da pesquisa}

A eletricidade é um vetor energético muito nobre, devendo ser destinada a aplicações de igual nobreza como processamento de dados, telefonia, iluminação, acionamento e força motriz. Utilizá-la para fins térmicos é filosoficamente desordenar energia, transformando um fluxo ordenado de cargas elétricas em calor. Outra incoerência conceitual é que a geração termelétrica, como o próprio nome indica, passa por um processo de geração de calor necessário à produção de trabalho mecânico, com baixa eficiência, para no final da cadeia ser novamente transformado em calor.

A relevância desta pesquisa parte da possibilidade da redução do consumo da energia primária utilizada na geração termelétrica, tendo em vista a perspectiva da sua participação crescente. Além disso, a baixa eficiência deste processo de geração de energia elétrica é uma má aplicação dos derivados de petróleo e representa significativas emissões de carbono e outros poluentes atmosféricos como materiais particulados, óxidos de nitrogênio, óxidos de enxofre e hidrocarbonetos não queimados.

Portanto, a aplicação de gases combustíveis nos processos industriais em substituição à eletrotermia, onde viável, é uma alternativa interessante tanto em seus aspectos social e governamental como para as indústrias em particular. Analisando conjunturalmente, os benefícios seriam a redução do consumo dos combustíveis nas termelétricas e das respectivas emissões, além da redução dos picos de demanda nas redes de transmissão e distribuição. Para as indústrias em particular existem diversas oportunidades como a redução da demanda contratada ou transferência do consumo de energia elétrica para outras aplicações sem acréscimo de demanda. $\mathrm{O}$ aumento de produtividade dos processos térmicos industriais pode também contribuir para a redução ou eliminação dos elevados custos da energia elétrica nos horários de ponta e multas por ultrapassagem.

E para o poder público, esta pesquisa pode colaborar para o planejamento, possibilitando até postergar investimentos em geração e distribuição, além das sugestões para um melhor detalhamento, compreensão e aplicação do Balanço de Energia Útil - BEU. 


\subsection{Objetivo geral}

Esta tese tem por objetivo apresentar as possibilidades da substituição da eletrotermia na indústria, nos usos finais em aquecimento direto e calor de processo, por gases combustíveis ${ }^{2}$ sob os aspectos energéticos, produtivos e estratégicos, principalmente num panorama onde a energia elétrica substituída viesse a reduzir a geração termelétrica.

Além das citadas possibilidades, a tese objetiva a elaboração de estimativas quanto aos potenciais de substituição da eletrotermia por gases combustíveis e seus impactos na energia primária.

Outro objetivo importante do estudo é apresentar alguns aspectos econômicos da conversão, considerando-se as eficiências dos energéticos, apresentando inclusive elementos de custo envolvidos nos investimentos.

E o objetivo final é apresentar as conclusões e conduzir este tema às reflexões necessárias no que diz respeito ao planejamento da matriz energética nacional.

\subsection{Objetivos específicos}

Esta pesquisa objetiva também alguns temas específicos como a análise das características e disponibilidade dos gases combustíveis sob o ponto de vista da substituição da eletrotermia, a quantificação do potencial tecnológico para conversão e a apresentação de sugestões para enriquecer o Balanço de Energia Útil a partir das informações exigidas no passado pelo documento Pesquisa de Consumo de Energia ${ }^{3}$.

E, como auxílio coadjuvante, a tese aborda alguns temas técnicos como gases combustíveis e seus sistemas de queima, com a finalidade de proporcionar uma orientação básica no tema.

\subsection{Metodologia}

Trata-se de estudo exploratório, de caráter analítico, fundamentado em pesquisas

\footnotetext{
${ }^{2}$ Como gases combustíveis considera-se principalmente gás natural e GLP, embora outros gases possam eventualmente ser empregados, conforme indicado no capítulo 3.

3 Documento editado em 1984 pelo Ministério das Minas e Energia - Conselho Nacional do Petróleo, o qual segue no Anexo 1.
} 
bibliográficas e complementado por trabalhos práticos desenvolvidos pelo autor convertendo, total ou parcialmente, aplicações da eletrotermia por gases combustíveis na indústria.

As estimativas para os potenciais de substituição da eletrotermia, em cada setor de atividade industrial, basearam-se em literatura específica, trabalhos acadêmicos, informações de profissionais da área e em estimativas do autor.

\subsection{Estrutura do trabalho}

O trabalho está estruturado em nove capítulos.

O capítulo 1 "Introdução" faz uma breve apresentação sobre energia, seguindo-se com a situação histórica do desenvolvimento da eletrotermia no panorama energético brasileiro, a inserção do tema e a relevância da pesquisa, culminando com os objetivos geral e específicos. O capítulo 2 "Conceitos Fundamentais" se inicia com uma revisão dos conceitos de eletrotermia, o ambiente tarifário da energia elétrica, e alguns aspectos referentes à potência e à produtividade dos equipamentos térmicos considerados na pesquisa. Estão também abordadas neste capítulo as modalidades de conversão da eletrotermia a partir da geração de calor com gases combustíveis, os aspectos do calor como energia útil e as leis da termodinâmica.

No capítulo 3 "Gases Combustíveis" são apresentados os gases combustíveis disponíveis, suas principais características, preços e disponibilidades para substituição da eletrotermia no âmbito desta pesquisa.

Em sequência, o capítulo 4 "Aspectos Tecnológicos na Transformação de Gases Combustíveis em Calor" tem por objetivo a apresentação sistematizada dos referidos aspectos de forma a possibilitar a orientação do leitor neste rico universo de opções quanto ao método de transferência de calor e sistema de combustão mais adequado.

O capítulo 5 "Alternativas para a Substituição da Eletrotermia no Aquecimento Direto" analisa cada setor industrial independentemente, estimando os potenciais para conversão da eletrotermia e os respectivos consumos de gás natural e GLP.

O capítulo 6 "Alternativas para a Substituição da Eletrotermia no Calor de Processo" dá sequência ao trabalho do capítulo anterior, agora com respeito ao calor de processo.

O capítulo 7 "Redução no Consumo de Energia Primária pela Substituição de Eletrotermia" consolida os potenciais estimados nos capítulos 5 e 6 , calcula as eficiências da geração 
termelétrica brasileira e estabelece os fatores de conversão de energia final em energia primária, permitindo comparar as economias de energia primária sob várias alternativas.

O capítulo 8 "Aspectos Econômicos na Substituição da Eletrotermia" apresenta as equivalências econômicas comparando o gás natural e o GLP com a eletricidade, além de fornecer subsídios quanto aos investimentos necessários para a conversão para gás.

E, finalmente, no capítulo 9 "Conclusões e Recomendações" são apresentadas as principais conclusões atendendo aos objetivos propostos na tese e feitas algumas recomendações. 


\section{CONCEITOS FUNDAMENTAIS}

Este capítulo tem por objetivo destacar os conceitos fundamentais necessários ao desenvolvimento e compreensão da tese, tendo sido elaborado a partir da revisão bibliográfica e do conhecimento próprio desenvolvido pelo autor ${ }^{4}$.

\subsection{Eletrotermia}

O Dicionário Petit Larousse (DUBOIS, 1960, p.359) define eletrotermia como "etude des effets caloriques dans leurs rapports avec l'électricité", ou seja, "estudo dos efeitos calóricos nas suas relações com a eletricidade" (tradução nossa). No Dicionário Aurélio (FERREIRA, 1988, p. 237), eletrotermia está definida sucintamente como "produção de calor pela eletricidade". Assim, a eletrotermia pode ser definida como a ciência da aplicação da energia elétrica em dispositivos que utilizam suas características para a geração de calor. Os dispositivos mais comumente encontrados são as resistências elétricas, as quais liberam calor por efeito Joule. Outros dispositivos de transformação de energia elétrica em calor se utilizam dos processos do arco elétrico como os eletrodos a arco direto (arco descoberto), eletrodos a arco resistência (arco submerso), eletrodos a arco indireto (arco radiante), das correntes de indução através de bobinas (correntes de Foucault), de micro-ondas, do laser, do plasma e das bombas termodinâmicas de calor.

A eletrotermia é amplamente utilizada em todos os ramos de atividades devido à praticidade proporcionada por este nobre vetor energético que é a eletricidade. Nas residências do Brasil, suas aplicações englobam o aquecimento de água em chuveiros elétricos, aquecedores de acumulação e máquinas de lavar roupas, o aquecimento de ar em secadoras de roupas, o aquecimento e a cocção em fogões e fornos elétricos a resistência e nos fornos de microondas, além do aquecimento de ambientes em regiões frias. Outros usos podem ainda ser citados como secadores de cabelos e ferros para passagem de roupas.

Nas atividades comerciais, as aplicações da eletrotermia são praticamente as mesmas já citadas nas residências, porém com equipamentos de maior porte e englobando também a geração de vapor.

\footnotetext{
${ }^{4} \mathrm{O}$ autor deste trabalho vem desenvolvendo trabalhos na área de processos térmicos no setor industrial ao longo de 38 anos de experiência profissional.
} 
Enquanto as aplicações residenciais e comerciais utilizam basicamente resistências elétricas e micro-ondas, abre-se um grande leque nas atividades industriais pela enorme diversidade de processos e equipamentos que utilizam a eletrotermia tanto para aquecimento direto como para calor de processo, cuja substituição é o tema central desta tese. Além dos equipamentos a resistência elétrica são também encontradas fontes de aquecimento através de arco elétrico, indução e outras anteriormente citadas.

\subsubsection{Ambiente tarifário}

As modalidades de contratação da energia elétrica no Brasil, por consumidores industriais, apresentam muitas opções tarifárias ${ }^{5}$. Porém tais opções estão sempre alinhadas com o propósito de atender o perfil de demanda, possibilitando adequar os investimentos e a estrutura existente tanto na geração como nos sistemas de transmissão e distribuição da energia elétrica. Como também ocorre em outros países, existe um pico de consumo de energia nas horas que as pessoas chegam a suas casas, ao término da jornada de trabalho. Esta demanda máxima do sistema elétrico torna-se mais grave ainda, em comparação com a maioria dos países, devido ao fato de o Brasil ser um país tropical, com hábito de banhos mais frequentes e da utilização de chuveiros elétricos, um equipamento de elevada potência comparando-se com os demais eletrodomésticos. Por esta razão, torna-se necessário desestimular o uso da eletricidade neste período. Como ainda não é possível penalizar os consumidores de baixa tensão através de uma tarifa mais elevada nas horas de ponta do sistema, como residências e pequenos comércios, esse encargo recai sobre os consumidores industriais.

Nas horas de maior consumo diário (horas de ponta) durante os dias úteis da semana, tarifas diferenciadas são impostas às indústrias durante os períodos de baixo e de alto índice pluviométrico, denominados respectivamente de ponta seca e de ponta úmida, devido à significativa participação da hidroeletricidade na matriz energética nacional. O período seco é constituído pelos meses de maio a novembro, enquanto o período úmido vai de dezembro a abril.

O valor pago pelas indústrias pelo uso da energia elétrica é constituído de duas parcelas principais: a demanda contratada e o consumo efetivo.

\footnotetext{
${ }^{5}$ A legislação tarifária pode ser consultada no site www.aneel.gov.br - biblioteca virtual.
} 
A demanda contratada tem por objetivo remunerar a infraestrutura disponibilizada para os consumidores, enquanto que o consumo se refere ao pagamento da energia efetivamente consumida. Existem ainda as modalidades de tarifação denominadas por tarifa convencional, tarifa azul e tarifa verde, cada uma apresentando diferentes opções, possibilitando que cada indústria escolha a modalidade tarifária que seja mais conveniente ao seu perfil de consumo.

\subsubsection{Potência dos equipamentos eletrotérmicos}

Os projetos dos equipamentos eletrotérmicos industriais seguem, de modo geral, uma premissa básica: minimizar o custo da demanda contratada com a concessionária, para reduzir o custo fixo mensal para o comprador destes equipamentos. Desta forma, a única alternativa para o projetista é o dimensionamento da potência dos equipamentos com os valores mais baixos quanto possíveis.

A Figura 4 mostra duas filosofias de dimensionamento de potência elétrica para atendimento ao mesmo consumo de energia, no mesmo período de tempo. O gráfico do lado esquerdo mostra a opção da prática de uma potência superdimensionada de $200 \mathrm{~kW}$ e, por essa razão, o controle do processo só mantém a potência ligada por períodos de 6 minutos a cada 12 minutos, para que a temperatura se mantenha nos valores estipulados. Já o gráfico do lado direito indica a opção do dimensionamento da potência exata e necessária para atender igual consumo de energia do processo, sem nenhuma folga. Note-se que, em ambos os casos didáticos, o consumo de energia foi de $60 \mathrm{kWh}$ no período indicado. Porém, as demandas apresentaram valores significativamente diferentes, de 100 e $200 \mathrm{~kW}$, respectivamente.

Perfis de consumo (ciclo de 36 minutos)

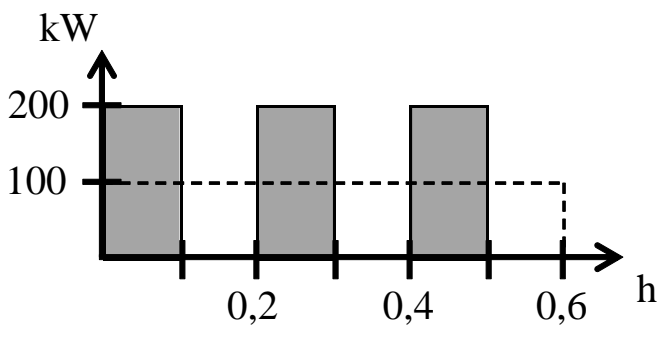

Potência $=200 \mathrm{~kW}$

Tempo ligado $=0,3 \mathrm{~h}$

Consumo $=60 \mathrm{kWh}$

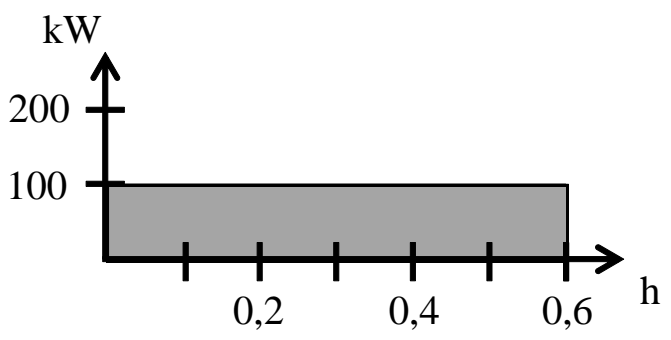

Potência $=100 \mathrm{~kW}$

Tempo ligado $=0,6 \mathrm{~h}$

Consumo $=60 \mathrm{kWh}$

Figura 4 - Perfis de consumo eletrotérmico em situações extremas

Fonte: elaboração própria 
Em ambas as opções da Figura 4, sob o ponto de vista do consumo de energia, a opção de projeto seria indiferente. Considerando o aspecto operacional, a opção da potência de $200 \mathrm{~kW}$ seria mais segura, pois haveria um excedente de potência para fazer frente a alguma eventualidade como dias muito frios ou matéria-prima fora de especificação, a qual exigisse uma maior potência para manter a mesma produtividade, como no caso de um eventual teor de umidade elevado na matéria prima. E sob o ponto de vista econômico, a opção da potência de $100 \mathrm{~kW}$ seria a mais interessante, pois acarretaria no menor custo da demanda contratada e no investimento mais baixo.

$\mathrm{Na}$ realidade nenhuma das duas opções de dimensionamento apresentadas na Figura 4 costuma ser praticada. A opção habitualmente escolhida está mais coerente com o perfil de consumo apresentado na Figura 5, onde a potência está dimensionada apenas com uma mínima folga, privilegiando uma menor demanda contratada, além do menor custo do equipamento e de sua instalação (subestação, cablagem, proteção etc.).

Perfis de consumo (ciclo de 36 minutos)

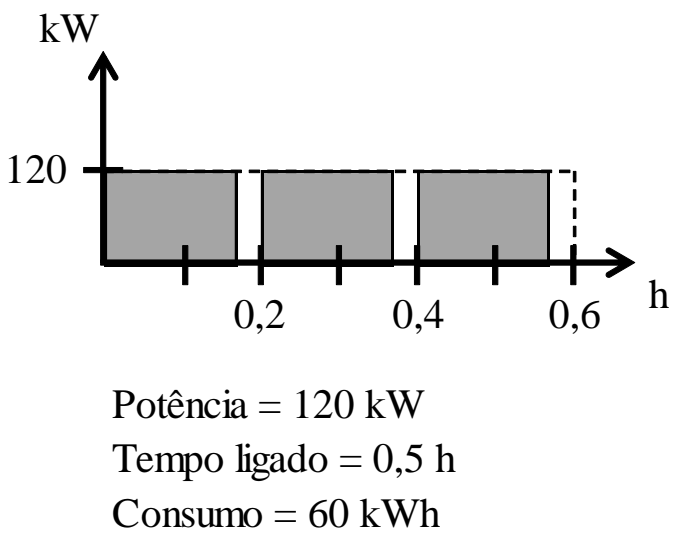

Figura 5 - Perfil de consumo eletrotérmico conservador

Fonte: elaboração própria

\subsubsection{Potência e produtividade}

Pode-se concluir então que os equipamentos eletrotérmicos, em sua maioria, apresentam potências subdimensionadas para alguns períodos de operação atípicos como preaquecimento na partida em dias muito frios, processamento de carga com elevada demanda térmica, como alto teor de umidade, ou necessidade de uma temperatura mais elevada. Nestas situações ocorre sempre uma redução da produtividade e, até mesmo, problemas com a qualidade 
quando esta depende da estabilidade do perfil térmico do processo, podendo onerar o produto com a elevação de custos ou reduzir seu valor quando ocorre perda da qualidade.

A experiência do autor permite afirmar que o aumento de produtividade é uma das possibilidades mais atrativas do processo de conversão de eletrotermia para gás, podendo ser obtido tanto pelo aumento da potência útil do equipamento como pelo aumento da taxa de transmissão de calor proporcionada pelo tráfego dos produtos da combustão no interior do equipamento térmico.

\subsubsection{Modalidades de conversão}

A conversão de um equipamento eletrotérmico pode apresentar diversos aspectos, sendo didaticamente repartida em dois grupos:

- Substituição total da eletrotermia

- Substituição parcial da eletrotermia

\subsubsection{Substituição total da eletrotermia}

A substituição total da eletrotermia é aquela onde a toda energia elétrica utilizada para gerar calor deixa de ser necessária ao processo térmico. Assim, existem duas opções:

- Conversão total do equipamento existente;

- Substituição do equipamento.

Na primeira opção, a conversão total do equipamento exige a instalação de um ou mais queimadores, dimensionados para atender à demanda térmica total. Dependendo do caso, os elementos eletrotérmicos poderão ou não ser eliminados mas, caso permaneçam instalados, serão considerados apenas como backup. Um aspecto muito importante a ser considerado é que este tipo de conversão possibilita o aumento da potência útil do equipamento sem o ônus do encargo fixo da demanda contratada, como ocorre no fornecimento da energia elétrica.

A segunda opção da conversão total é aquela onde o equipamento eletrotérmico é desativado, sendo substituído por seu congênere a gás combustível. Essa substituição é praticada quando não seja viável, técnica ou economicamente, fazer a conversão energética no equipamento. Os 
casos mais comuns são os equipamentos industriais de calor de processo, aquecidos por resistências elétricas ou eletrodos, onde o procedimento mais indicado é a substituição do equipamento através da compra dos seus congêneres a gás. De modo geral esta opção, embora exija maiores investimentos, possibilita manter o equipamento elétrico em condições de operação, seja na hipótese de backup como também para possibilitar negociações comerciais com ambas as modalidades de energia.

\subsubsection{Substituição parcial da eletrotermia}

A substituição parcial da eletrotermia é aquela onde apenas parte da energia elétrica usada na geração de calor é substituída por gás combustível, com os objetivos de reduzir o consumo e/ou a demanda de eletricidade e, ainda, de aumentar a produtividade.

Existem duas modalidades para a substituição parcial da eletrotermia, onde a aplicação do gás combustível pode ser feita:

- no próprio equipamento eletrotérmico;

- ou fora do equipamento, numa etapa anterior ou posterior.

A aplicação do gás combustível no próprio equipamento eletrotérmico torna necessária a instalação de queimadores auxiliares de forma que ambos os energéticos possam operar simultaneamente, embora em algumas situações possam funcionar independente ou sequencialmente por motivos de ordem técnica ou estratégica. Por exemplo, no caso da fusão de metais, um motivo de ordem técnica seria a utilização dos queimadores a gás no início da corrida, quando o metal ainda se encontra no estado sólido, pois a eficiência da troca térmica é mais elevada e a oxidação de elementos da liga metálica por ação da chama é pequena ou desprezível. Já um motivo de ordem estratégica poderia ser a antecipação do início da corrida apenas com queimadores a gás, ainda durante o período de ponta do sistema elétrico, preaquecendo e fundindo o metal, abreviando assim o final da corrida que seria concluída com eletricidade já fora do horário de ponta.

$\mathrm{O}$ autor testou e pôs em prática esse conceito estratégico num forno elétrico a arco, na Siderúrgica de Boyacá - Sideboyacá, em Tuta - Colômbia, durante o apagão nos anos de 1992 e 1993. Como na ocasião não havia disponibilidade de gás natural naquela localidade, foram desenvolvidos queimadores auxiliares para queimar um tipo especial de petróleo cru, 
chamado Crudo de Castilla, com oxigênio puro. Este óleo pesado pode ser aplicado diretamente em queimadores, bastando aquecê-lo a temperaturas na faixa de $100^{\circ}$ a $120^{\circ} \mathrm{C}$ para baixar sua viscosidade, possibilitando sua atomização de forma análoga aos óleos combustíveis brasileiros com baixo ponto de fluidez (BPF). Os resultados encontrados foram significativos, resumindo-se em:

- redução do consumo específico médio de energia elétrica de 600 para $420 \mathrm{kWh} / \mathrm{ton}$ aço vazado;

- aumento de produtividade da ordem de $10 \%$, possibilitando recuperar parte significativa da produção perdida nas três horas de ponta, quando a energia elétrica não devia ser utilizada;

- e, também, na redução do consumo específico de eletrodos, que é proporcional ao consumo de energia elétrica.

A outra modalidade, que pode ainda ser considerada na categoria de conversão parcial, referese à aplicação do gás fora do equipamento eletrotérmico, em uma etapa anterior ou posterior da cadeia produtiva. Essa alternativa é também aplicada quando existe a necessidade do aumento da produtividade. Exemplos típicos são o preaquecimento a gás da carga que será alimentada no forno elétrico ou, até mesmo, fazer a pré-fusão de metais em forno a gás de forma a alimentar o forno elétrico com metal já no estado líquido, onde então se processarão as etapas de refino, ajuste de temperatura e espera para vazamento. Este processo, que utiliza dois fornos de gêneros distintos para fundir e refinar os metais de forma sequencial, é conhecido por Processo Duplex.

\subsection{Geração de calor com gases combustíveis}

A geração de calor através da combustão é o resultado da transformação parcial da energia química contida nas ligações entre os átomos que constituem as moléculas dos combustíveis em calor, por meio de sua oxidação, ou seja, combustão.

Nesta tese, a alternativa proposta à eletrotermia é sua conversão por gases combustíveis, principalmente devido às suas características ambientalmente amigáveis quando comparados com os óleos combustíveis e com os carvões minerais. 
De acordo com Lackner, Winter, e Agarwal, (2010, volume 3, pág. 237, tradução nossa), um combustível gasoso para ser considerado como combustível industrial deve apresentar as seguintes características:

- disponibilidade local

- qualidade mínima

- custo viável

- entrega assegurada.

A principal característica técnica de um gás combustível é seu poder calorífico enquanto que, sob o aspecto econômico, seria seu preço específico expresso em reais por determinada quantidade de calor como, por exemplo, reais por megacaloria ou, internacionalmente, como dólares norte-americanos por milhão de BTU. Para se determinar o custo específico de combustíveis é necessário conhecer o poder calorífico do gás e seu preço.

O poder calorífico pode ser superior ou inferior. A definição de poder calorífico superior (PCS) apresenta algumas diferenças sutis, segundo a filosofia de cada autor. Bartok (1991) define o PCS na situação em que, além do calor normalmente liberado pelos produtos gasosos da combustão, o calor latente de condensação do vapor d'água contido nos produtos da combustão foi também absorvido pelo processo térmico onde o gás foi aplicado. Nesta definição faltou citar a liberação do calor sensível da água condensada e a necessidade de uma temperatura de referência. E Bartok (1991) define ainda o poder calorífico inferior (PCI) no caso onde o calor latente de condensação do vapor d'água não foi aproveitado, ou seja, tratase do valor do PCS menos este calor latente, também não considerando o calor sensível da água condensada até a temperatura de referência.

Reed (1986) explica mais criteriosamente o sentido do PCS, como sendo o calor total liberado quando uma mistura perfeita de combustível e ar (o autor se refere à mistura nas proporções estequiométricas), originalmente a $60^{\circ} \mathrm{F}\left(15,5^{\circ} \mathrm{C}\right)$ entra em ignição e os produtos da combustão completa são então resfriados de forma a retornarem aos $60^{\circ} \mathrm{F}$, o que inclui o calor liberado pela condensação do vapor d'água presente nos produtos da combustão e o calor sensível da água condensada até a temperatura de referência. E a definição de PCI por Reed (1986) é semelhante à de Bartok (1991), sendo o igual ao PCS menos o calor latente de condensação do vapor d'água presente nos produtos da combustão. Em ambas as definições do PCI não se faz referência ao calor sensível da água condensada até a temperatura de referência.

As definições mais completas seriam associar os conceitos de Pritchard (1977) e Her Majesty's Stationery Office (1969). Assim, o PCS seria o calor liberado por uma quantidade 
unitária do gás combustível através da combustão completa em condição isotérmica e isobárica a 1 atmosfera absoluta e na temperatura de referência, onde todo o carbono foi convertido em $\mathrm{CO}_{2}$, o hidrogênio em $\mathrm{H}_{2} \mathrm{O}$, o enxofre em $\mathrm{SO}_{2}$, o nitrogênio não formou nenhum óxido e o vapor d'água formado na combustão foi condensado e retornou à temperatura de referência. A definição de temperatura e pressão de referência na condição standard (stp) varia significativamente na literatura mundial, de acordo com a norma ou a entidade, sendo encontradas temperaturas de $0^{\circ} \mathrm{C}, 15^{\circ} \mathrm{C}, 20^{\circ} \mathrm{C}$ e $25^{\circ} \mathrm{C}$, bem como $59^{\circ} \mathrm{F}, 60^{\circ} \mathrm{F}$ e $70^{\circ} \mathrm{F}$ e pressões atmosféricas de $100 \mathrm{kPa}, 101,3 \mathrm{kPa}, 101,325 \mathrm{kPa}, 14,503 \mathrm{psi}, 14,696 \mathrm{psi}$, 14,73 psi e 29,92 in Hg. Portanto, nada parece menos standard do que a condição standard de temperatura e pressão, a qual necessita sempre ser por esta razão explicitamente definida. $\mathrm{Na}$ indústria mundial de petróleo e gás considerou-se tradicionalmente a condição standard como $60^{\circ} \mathrm{F}$ e 14,696 psi, que corresponderia no sistema métrico a $15,6^{\circ} \mathrm{C}$ e $101,325 \mathrm{kPa}$. No Brasil, as condições de referência estabelecidas pela ANP para o gás natural são a temperatura de $20^{\circ} \mathrm{C}$, mais adequada ao país, e a pressão atmosférica de 1 atm $(101,325 \mathrm{kPa})$.

E, por sua vez, o PCI seria calculado subtraindo-se do PCS do gás combustível o calor latente de condensação do vapor d'água e o calor sensível da água presente nos produtos da combustão da quantidade unitária do gás combustível, incluindo-se o eventual teor de umidade originalmente presente no gás, considerando-se as condições de referência.

As diferenças percentuais entre o PCS e o PCI dos combustíveis em geral e, em particular, dos gases combustíveis, varia em função da quantidade de água gerada na combustão, a qual é diretamente proporcional ao teor de hidrogênio contido no combustível, desconsiderando-se eventual teor de umidade. Assim, a diferença máxima ocorre quando o gás combustível é o hidrogênio puro, onde o PCI é igual a 84,26\% do PCS conforme indicado pela Tabela 1.

Tabela 1 - Relação entre PCI e PCS dos gases combustíveis

\begin{tabular}{cccccc}
\hline GÁS COMBUSTÍVEL & MOL & $\begin{array}{c}\text { HIDROGÊNIO } \\
(\% \text { massa })\end{array}$ & $\begin{array}{c}\text { PCS } \\
\left(\mathrm{kcal} / \mathrm{m}^{3}\right)^{*}\end{array}$ & $\begin{array}{c}\text { PCI } \\
\left(\mathrm{kcal} / \mathrm{m}^{3}\right)^{*}\end{array}$ & $\begin{array}{c}\text { Relação PCI-PCS } \\
(\%)\end{array}$ \\
\hline Hidrogênio & 2 & 100,0 & 2.843 & 2.403 & 84,52 \\
Metano & 16 & 25,0 & 8.854 & 7.976 & 90,08 \\
Etano & 30 & 20,0 & 15.515 & 14.189 & 91,45 \\
Propano & 44 & 18,2 & 22.075 & 20.322 & 92,06 \\
Butano & 58 & 17,2 & 28.627 & 26.418 & 92,28 \\
Monóxido de carbono & 28 & 0,0 & 2.813 & 2.813 & 100,00 \\
\hline
\end{tabular}

Fonte: elaboração própria a partir dos dados de Perry e Green (1984)

* a $1 \mathrm{~atm}, 20^{\circ} \mathrm{C}$ 
E, quando o gás combustível não possui hidrogênio, como o monóxido de carbono puro, o PCS e o PCI são iguais. Isto permite concluir que, para todos os combustíveis, o PCI estará compreendido entre $84,26 \%$ e $100 \%$ do PCS.

A Tabela 1 mostra ainda o relacionamento entre PCI e PCS de alguns gases combustíveis, onde se confirma que quanto maior o teor de hidrogênio do combustível, maior a diferença entre o PCI e o PCS.

Com respeito à escolha do poder calorífico, superior ou inferior, para a realização de cálculos energéticos e econômicos, devem ser considerados:

- Em quase a totalidade dos processos, onde não há condensação do vapor d'água presente nos produtos da combustão no equipamento térmico, a escolha do PCI é, sem dúvida, a mais recomendável.

- A utilização do PCS deveria ser considerada apenas em casos excepcionais, nos processos como combustão submersa e aquecedores de condensação, onde pelo menos parte do vapor d'água presente nos produtos da combustão condensa, cedendo seu calor latente para o equipamento térmico.

Sob o ponto de vista comercial, algumas empresas preferem informar apenas o poder calorífico que torna seu combustível mais competitivo na comparação com seus concorrentes. Por exemplo, se compararmos o metano com o propano, considerando:

- o PCS, $1 \mathrm{~m}^{3}$ de metano equivale a $0,4011 \mathrm{~m}^{3}$ de propano;

- o PCI, $1 \mathrm{~m}^{3}$ de metano equivale a $0,3925 \mathrm{~m}^{3}$ de propano.

Assim, para uma empresa de gás natural existe uma vantagem aparente da ordem de $2 \%$ na comparação com GLP quando se utiliza o PCS. De forma análoga, também existem ganhos na comparação do gás natural com os óleos combustíveis, os quais são ainda mais significativos do que os valores estimados para o GLP, pois os óleos apresentam teores de hidrogênio ainda mais baixos. Quanto mais pesado for o óleo combustível, apresentando cadeias moleculares maiores, menor será o teor de hidrogênio no combustível e maior seria a vantagem aparente do gás natural nas comparações através do PCS. 
Nesta tese serão considerados os seguintes poderes caloríficos inferiores, de acordo com o MME (2013b):

- tonelada equivalente de petróleo (tep): $\quad 10.000 .000 \mathrm{kcal}$

- tonelada de GLP: $\quad 11.100 .000 \mathrm{kcal}$

- $10^{3} \mathrm{~m}^{3}$ de $\mathrm{GN}$ seco $\left(\mathrm{a} 20^{\circ} \mathrm{C}, 1 \mathrm{~atm}\right)$ : $\quad 8.800 .000 \mathrm{kcal}$

\subsection{Calor como energia útil}

A energia útil, como calor, pode ser classificada sob dois aspectos: aquecimento direto e calor de processo.

\subsubsection{Aquecimento direto}

Denomina-se aquecimento direto quando o vetor energético, como eletricidade, gás ou outros combustíveis, é aplicado diretamente no equipamento térmico industrial, sem a existência de um fluido intermediário como vapor, água quente ou óleo térmico que transporte o calor do energético para a carga do equipamento.

Os equipamentos térmicos onde o aquecimento direto é aplicado, geralmente fornos, fornalhas e secadores, apresentam uma enorme diversificação considerando o energético, a aplicação, o formato, o porte, o material construtivo e a modalidade operacional. Mesmo quando uma única aplicação está sendo considerada como, por exemplo, a fusão de lingotes e de sucata de alumínio, existe uma grande diversidade de fornos elétricos e de fornos a combustíveis, de diferentes portes, como fornos de indução, fornos de cadinho, fornos revérberos, fornos rotativos e fornos tipo pera.

A modalidade operacional dos equipamentos térmicos apresenta duas grandes divisões:

- equipamentos de operação contínua;

- e equipamentos de operação descontínua ou intermitentes.

Os equipamentos térmicos de operação contínua, como o próprio nome indica, caracterizamse pela alimentação da carga no equipamento e pela respectiva descarga, ambas cadenciadas. Portanto estes equipamentos dispõem de um dispositivo de transporte para a carga, como esteira, corrente, vagoneta etc. Na maioria das vezes essa movimentação é contínua, 
mantendo-se o elemento transportador em velocidade constante. Por exemplo, fornos tipo túnel para cocção de pães e biscoitos.

Porém existem alguns processos que, embora sejam considerados de operação contínua, o elemento transportador não trafega em velocidades constantes. Um exemplo é o forno túnel para queima de materiais cerâmicos, como porcelana e louça sanitária, onde as peças são colocadas sobre mobília nas vagonetas, as quais são alimentadas ao forno uma a uma. A entrada de uma vagoneta acarreta na saída de outra vagoneta. Assim, o conjunto de vagonetas atravessa o forno-túnel movimentando-se em intervalos de tempo discretos, submetendo a carga ao perfil de temperaturas predeterminado. Outro exemplo de equipamento de operação contínua são os grandes fornos de vidros das indústrias automáticas, onde a mistura de matérias-primas é alimentada de forma não contínua, a partir da queda do nível de vidro fundido, que é proporcional à extração (produção).

Os equipamentos térmicos de operação descontínua ou intermitentes são aqueles onde a carga é carregada, em uma ou mais vezes, realiza-se todo o processo, e o produto é descarregado iniciando-se novamente outro ciclo.

De modo geral, os equipamentos de operação contínua apresentam um rendimento térmico mais elevado do que os equipamentos de operação descontínua, além de possibilitar um melhor controle da qualidade. Os processos de operação contínua apresentam, principalmente, duas vantagens com relação ao seu balanço térmico:

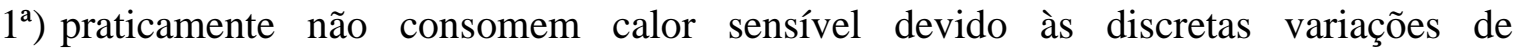
temperatura da estrutura do equipamento;

$2^{a}$ ) e possibilitam uma recuperação de calor dos produtos da combustão de uma forma contínua, o que pode ser significativo no caso da conversão de eletrotermia para gás combustível.

Um exemplo característico é o forno túnel elétrico para queima de revestimentos cerâmicos decorados que, ao ser convertido para gás, aproveita o fluxo de produtos da combustão no sentido contracorrente da carga para secá-la e preaquecê-la, recuperando o calor proveniente da zona de alta temperatura e, portanto, minimizando perdas térmicas.

Quanto ao energético, os equipamentos classificados como do tipo aquecimento direto podem utilizar tanto a energia elétrica como combustíveis sólidos, líquidos e gasosos. 
Sendo o vetor energético a eletricidade, a geração de calor utiliza as propriedades da corrente elétrica; nos processos térmicos industriais são mais frequentemente encontrados as resistências elétricas, os eletrodos e as bobinas de indução.

Quando o vetor energético é um combustível gasoso, líquido ou sólido, existem três modalidades de aquecimento direto a serem consideradas, as quais são consequências diretas da compatibilidade do contato dos produtos da queima do combustível com a carga do equipamento:

- Na primeira modalidade, os produtos da combustão entram em contato direto com a carga a aquecer. Geralmente esta é a forma onde são obtidos os maiores rendimentos térmicos para cada processo, devido às modalidades de transmissão de calor por condução, convecção e radiação serem favorecidas. Porém, não deve haver nenhuma restrição ao contato direto dos produtos da combustão com a carga e com a atmosfera desses fornos. Essas restrições podem ser devido à formação e presença de materiais particulados, óxidos de enxofre, radicais aromáticos, oxigênio e outros subprodutos oriundos da queima, cujo contato com a carga seja considerado indesejável por motivos como contaminação, ataque químico, alteração de cores, oxidação, risco de inflamabilidade etc.

- Na segunda modalidade, a combustão é estabelecida num ambiente isolado e estanque, por alguma restrição ao contato com a carga, onde os produtos da combustão aquecem uma superfície cerâmica ou metálica que, por sua vez, transmite o calor para a carga. Exemplos típicos são os fornos de tratamento térmico com atmosfera controlada, onde é indesejável a presença de gases da combustão em contato com a carga, pois esta deve estar protegida por uma atmosfera sintética, com características especiais (neutra, redutora, carburante, nitretante etc.) necessária e específica ao tratamento que está sendo submetida, como recozimento brilhante, cementação, nitretação e carbonitretação.

- E, na terceira modalidade, as chamas estão parcialmente confinadas no interior de uma estrutura metálica ou cerâmica para não atingirem diretamente a carga, evitando assim o superaquecimento, porém permitindo o contato dos produtos da combustão com a carga em temperaturas inferiores à da chama, as quais não venham a causar danos. 
Existem diversos tipos de estruturas que segregam os produtos da combustão da carga de um equipamento térmico. Um dos tipos mais comuns são os tubos radiantes, onde as chamas trafegam no interior desses tubos aquecendo-os, os quais estão instalados na câmara de processo do equipamento a ser aquecido, liberando os produtos da combustão na atmosfera exterior ao equipamento térmico. Os materiais utilizados na construção desses tubos radiantes variam de acordo com a temperatura e a agressividade do processo, podendo ser metálicos como aço carbono, aço inoxidável e, até mesmo, superligas como ferro-cromo-alumínio. Os tubos radiantes podem ser ainda fabricados com materiais cerâmicos e carbeto de silício.

Outra filosofia para segregar os produtos da combustão é confinar a carga no interior de uma mufla, deixando o tráfego das chamas e dos produtos da combustão circular pelo espaço compreendido entre a mufla e a estrutura do equipamento. Essa mufla pode ser fabricada com materiais cerâmicos ou metálicos que, aquecidos, transmitem o calor dos queimadores para a carga do forno.

\subsubsection{Calor de processo}

Entende-se por calor de processo quando o energético não é aplicado diretamente no processo final, necessitando de um meio intermediário para transportar o calor ou energia, como vapor d'água, água quente e fluidos térmicos. Embora o campo de aplicação do calor de processo seja muito amplo, os equipamentos utilizados são de certa forma padronizados como caldeiras de vapor e aquecedores de fluidos (água ou óleos térmicos), a grande maioria fabricada em série por empresas especializadas. Mas existem também alguns equipamentos fabricados sob medida, principalmente quando se trata de equipamentos eletrotérmicos resistivos, algumas vezes construídos até mesmo pela própria indústria que o utiliza.

Os equipamentos mais comumente encontrados nas indústrias são as caldeiras a vapor saturado, onde a relação biunívoca entre pressão e temperatura facilitam o dimensionamento dos trocadores de calor e o controle de temperatura. Certamente a grande quantidade de caldeiras a vapor existentes nas indústrias motivou os colaboradores da Empresa de Pesquisa Energética - EPE a utilizarem a capacidade de geração de vapor como referência na classificação dos setores de aplicação. Existem ainda as caldeiras de vapor superaquecido, mais comumente utilizadas para geração de trabalho mecânico através de turbinas e mover geradores de energia, bombas, ventiladores etc., com possibilidade de aproveitamento do efluente de vapor para processo térmico na indústria. 
Os aquecedores de água para fins industriais, também denominados geradoras de água quente ou caldeiras de água quente, se subdividem em dois tipos: água não pressurizada (pressão atmosférica) para temperaturas inferiores a $100^{\circ} \mathrm{C}$ e água pressurizada, chamada de água superaquecida, para temperaturas acima de $100^{\circ} \mathrm{C}$ que, geralmente, não ultrapassam $200^{\circ} \mathrm{C}$ de acordo com as limitações da pressão máxima de trabalho admissível do equipamento.

E os aquecedores de fluidos térmicos, os quais abrangem faixas de temperatura de até $400^{\circ} \mathrm{C}$, possibilitam o aquecimento de processos onde a utilização de vapor saturado exigiria pressões de trabalho muito elevadas, portanto impraticável para trocadores de calor convencionais, ou até mesmo temperaturas impossíveis por estarem acima da temperatura crítica da água, $374,15^{\circ} \mathrm{C}$.

No calor de processo, toda a eletrotermia pode ser substituída por gases combustíveis onde, em quase a totalidade dos casos, exige a substituição do equipamento elétrico pelo seu sucedâneo a gás.

\subsection{Termodinâmica}

\subsubsection{Sistema Termodinâmico e Volume de Controle}

A definição de termodinâmica em conceito amplo, segundo Marques (1969), mostra ser uma ciência de grande extensão, compreendendo o estudo da energia e suas transformações, responsável pelo estabelecimento das bases do conhecimento de todos os fenômenos naturais. Já com um enfoque mais objetivo, Van Wylen e Sonntag (1973) definem a termodinâmica como "a ciência que trata do calor e do trabalho, e daquelas propriedades das substâncias relacionadas ao calor e ao trabalho."

Para a realização de um estudo termodinâmico, é necessário segregar uma região do espaço, o que pode ser feito através dos conceitos de Sistema Termodinâmico e de Volume de Controle. Define-se sistema termodinâmico quando o estudo se refere a uma determinada quantidade de matéria onde não há fluxo de massa e sua identidade não varia. Toda a região situada fora do sistema é denominada meio, exterior ou vizinhança. E a interface que separa o exterior do sistema é chamada fronteira do sistema, podendo ser fixa ou móvel. Os sistemas termodinâmicos se aplicam em duas situações: 
$1^{\text {a) }}$ Sistema isolado, onde calor e trabalho não cruzam a fronteira do sistema e, portanto, não é influenciado pelo meio.

$2^{\mathrm{a}}$ ) Sistema fechado, onde apenas calor e trabalho podem cruzar a fronteira do sistema, conforme Figura 6.

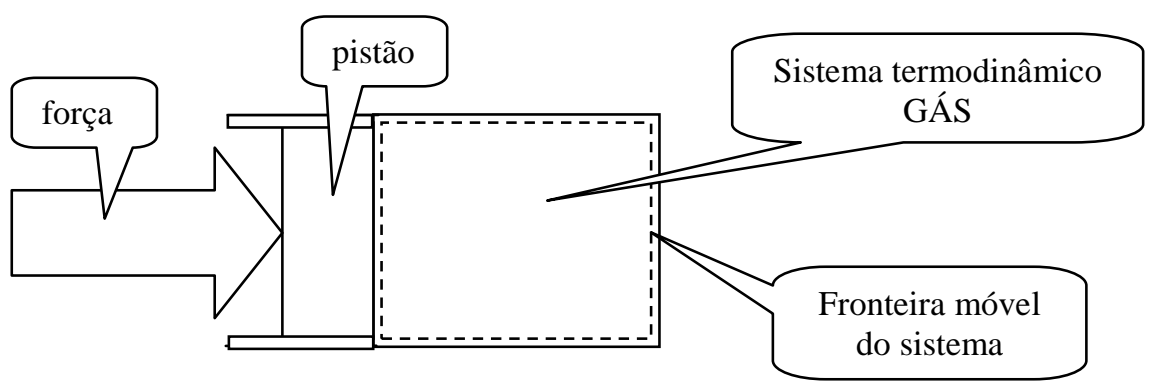

Figura 6 - Exemplo de sistema termodinâmico fechado

Fonte: elaboração própria

Já o volume de controle é aplicado no estudo dos sistemas abertos, os quais caracterizam-se pelos fluxos de massa através de uma fronteira estabelecida para análise, chamada superfície de controle, a qual pode ainda ser atravessada por calor e trabalho. Estes sistemas são os mais importantes no desenvolvimento desta tese, onde serão estudados equipamentos como fornos, caldeiras e sistemas de geração termelétricos.

A Figura 7 ilustra um sistema aberto e seu volume de controle.

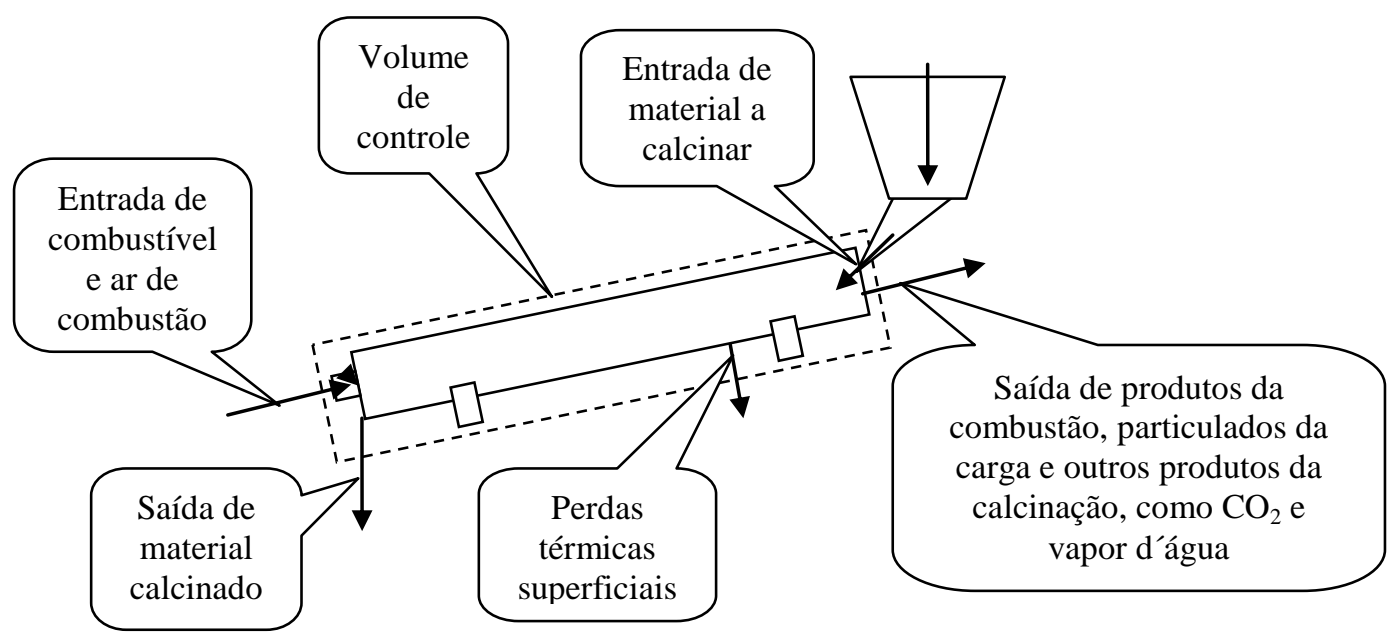

Figura 7 - Exemplo de sistema aberto - forno rotativo de calcinação

Fonte: elaboração própria 


\subsubsection{Lei Zero da Termodinâmica}

O primeiro conceito é o da transmissão de calor e do equilíbrio térmico. Um exemplo prático é colocar em contato dois cubos metálicos com temperaturas diferentes, com uma face sobre a face do outro, no interior de um sistema isolado. O calor fluirá do bloco de maior temperatura para o bloco de menor temperatura através do processo de condução de calor, até que seja atingido o equilíbrio térmico.

A Lei Zero da Termodinâmica, assim denominada por preceder a Primeira Lei, é enunciada como: "Havendo equilíbrio térmico de dois sistemas com um terceiro, todos estão em equilíbrio entre si." Assim, a temperatura pode ser definida como a propriedade que determina o estado de equilíbrio térmico dos sistemas. Havendo equilíbrio térmico, a temperatura é representada por um mesmo valor referido a uma determinada escala.

\subsubsection{Primeira Lei da Termodinâmica}

\subsubsection{Aspecto da conservação da energia}

A Primeira Lei da Termodinâmica estabelece o princípio da conservação da energia.

O enunciado elaborado por Dillio e Nye (1959, pág. 49, tradução nossa), o qual apresenta um conteúdo mais filosófico, é o seguinte: "Energia não pode ser quantitativamente criada nem destruída. Ela pode ser convertida de uma forma para outras formas, pode ser armazenada e retirada, mas a quantidade total deve permanecer constante."

Assim temos, em regime permanente:

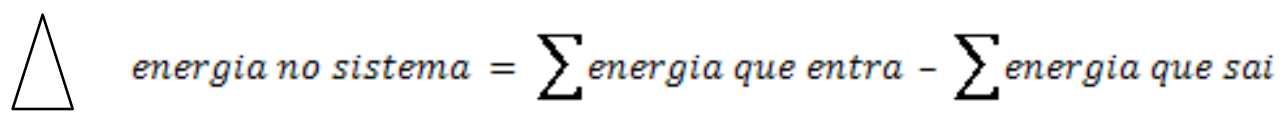

Um exemplo simplificado dos fluxos de massa e energia a serem considerados na elaboração de um balanço energético de uma geradora de vapor saturado a gás natural, considerando-se ainda a aplicação de vapor vivo em um processo industrial, onde não há retorno de condensado para este equipamento térmico, segue na Figura 8. O não retorno de condensado, implica que toda a água de alimentação da caldeira seja injetada na temperatura ambiente pois 
não foi considerado, neste exemplo, o aproveitamento do calor contido nos produtos da combustão para o preaquecimento da água nem para o preaquecimento do ar de combustão, como ocorre na maioria das geradoras de vapor de pequeno porte.

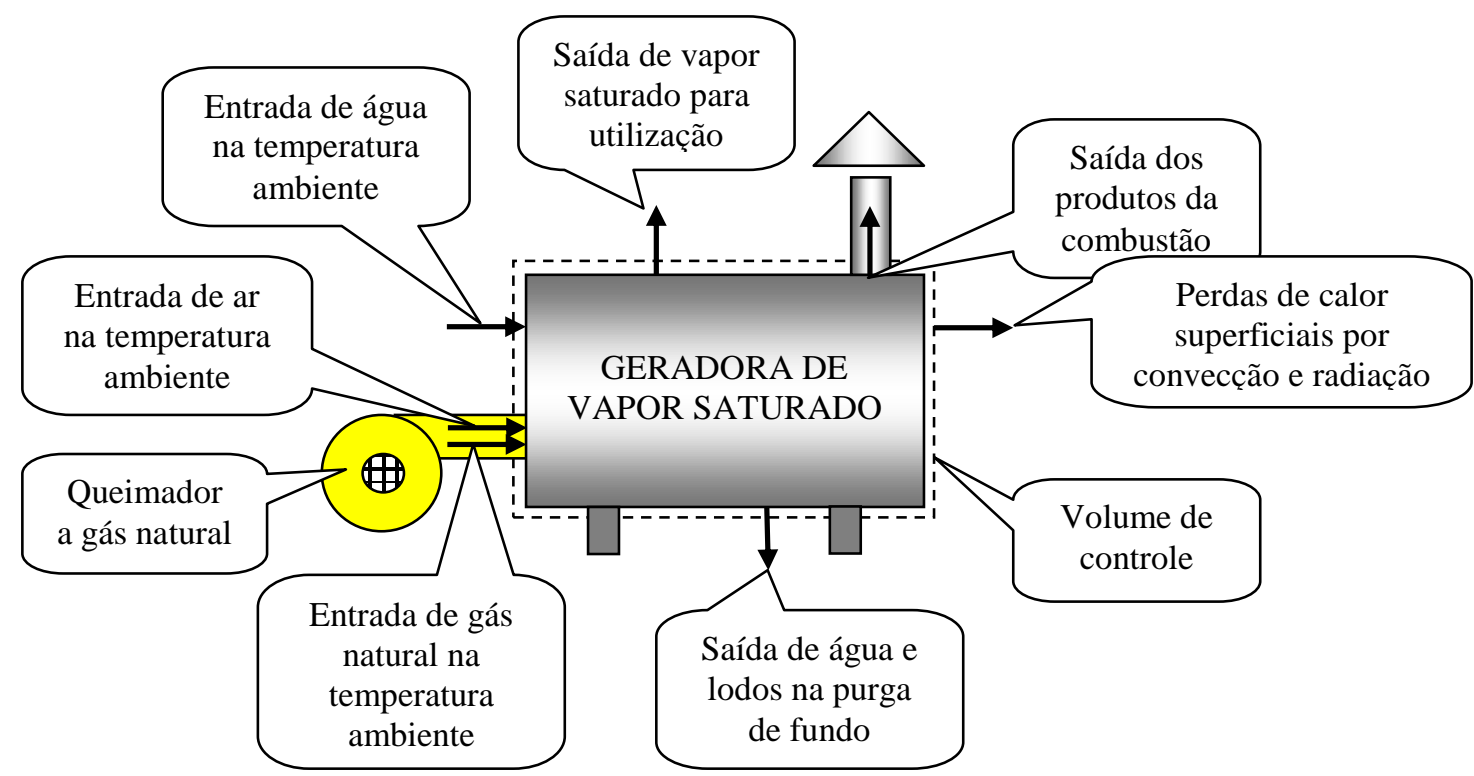

Figura 8 - Geradora de vapor saturado a gás natural

Fonte: elaboração própria

O balanço de massa satisfaz ao princípio da conservação da massa. Assim,

$\sum$ massa que entra $=\sum$ massa que sai

- Fluxo de massa que entra no volume de controle $\left(\dot{\mathrm{m}}_{\mathrm{entra}}\right)$ :

$$
\dot{\mathrm{m}}_{\text {entra }}=\dot{\mathrm{m}}_{\text {água }}+\dot{\mathrm{m}}_{\mathrm{gás}}+\dot{\mathrm{m}}_{\mathrm{ar}}
$$

- Fluxo de massa que sai do volume de controle $\left(\dot{\mathrm{m}}_{\mathrm{sai}}\right)$ :

$$
\dot{\mathrm{m}}_{\text {entra }}=\dot{\mathrm{m}}_{\text {sai }}=\dot{\mathrm{m}}_{\text {vapor }}+\dot{\mathrm{m}}_{\text {prod.combustão }}+\dot{\mathrm{m}}_{\text {purga }}
$$

Balanço de energia ( $1^{\text {a }}$ Lei) em relação à temperatura ambiente:

Como o sistema não realiza trabalho e considerando o regime estacionário onde não há variação de energia no sistema, o fluxo de energia que entra no volume de controle é igual ao fluxo de energia que sai, segundo a Equação 1. 
- Fluxo de energia que entra $\dot{E}_{\text {entra: }}$ :

$$
\dot{\mathrm{E}}_{\text {entra }}=\dot{\mathrm{E}}_{\text {gas }}
$$

- Fluxo de energia que sai $\left(\dot{\mathrm{E}}_{\mathrm{sai}}\right)$ :

$$
\dot{\mathrm{E}}_{\text {entra }}=\dot{\mathrm{E}}_{\mathrm{sai}}=\dot{\mathrm{E}}_{\mathrm{vapor}}+\dot{\mathrm{E}}_{\text {prod.combustão }}+\dot{\mathrm{E}}_{\text {perdas superficiais }}+\dot{\mathrm{E}}_{\text {purga }}
$$

Desta forma,

$$
\dot{\mathrm{E}}_{\text {gás }}=\dot{\mathrm{E}}_{\mathrm{vapor}}+\dot{\mathrm{E}}_{\text {prod.combustão }}+\dot{\mathrm{E}}_{\text {perdas superficiais }}+\dot{\mathrm{E}}_{\text {purga }}
$$

Quantificando o balanço de massa e de energia torna-se necessário expor, de uma forma gráfica e de fácil visualização, o referido balanço tomando-se por base a Primeira Lei. Esta forma de representação chama-se Diagrama de Sankey. Assim, o Diagrama de Sankey é a expressão gráfica de um balanço de energia, através de um diagrama de fluxo de calor. Inicia-se o diagrama com um esboço do sistema, mostrando suas partes e interconexões, onde os fluxos de entrada e saída de energia são representados por setas que fluem nas mesmas sequências físicas do processo. Além disso, as larguras das setas são estabelecidas de forma proporcional aos seus respectivos fluxos ou seja, as setas mais largas correspondem aos fluxos mais intensos e vice-versa.

A Figura 9 foi traçada a partir de valores típicos para exemplificar o caso de uma caldeira geradora de vapor saturado.

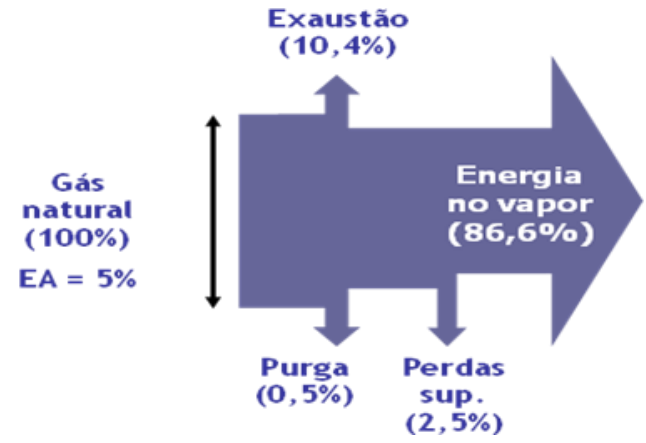

Figura 9 - Exemplo de diagrama de Sankey para geradoras de vapor

Fonte: elaboração própria 
Em cada balanço energético os valores encontrados são particulares a cada caso, onde até mesmo equipamentos semelhantes costumam apresentar balanços energéticos diferentes. As variações encontradas para geradoras de vapor podem ser devido a uma série de fatores como:

- Porte do equipamento: equipamentos de maior porte apresentam economia de escala e eficiências energéticas mais elevadas.

- Configuração: existência de equipamentos periféricos para recuperação de calor como preaquecedores de água e de ar.

- Aplicação: se a aplicação do vapor é indireta ou direta, o que implica na existência ou não do retorno de condensado respectivamente e na temperatura de alimentação da água na geradora.

- Estado de manutenção: estado em que se encontra a geradora, como a limpeza dos tubos de troca de calor, a integridade do isolamento térmico e a regulagem do queimador.

- Fator de carga: demanda de vapor em função da capacidade da geradora, pois equipamentos superdimensionados trabalhando em baixa carga se tornam menos eficientes em virtude das perdas fixas, no caso perdas superficiais, que são constantes no tempo.

\subsubsection{Balanço de massa e energia}

A elaboração do balanço de massa e energia de um sistema ou, no caso particular desta tese, de um equipamento térmico onde o trabalho não cruza a fronteira do sistema, realiza-se em duas etapas:

$1^{\text {a) }}$ Levantamento de campo:

- Inicia-se com o desenho esquemático do equipamento e com a indicação de todos os fluxos de entrada e saída de massa e de calor sob o aspecto qualitativo. Escolhe-se então o volume de controle, traçando-se a superfície de controle que o envolve, e a temperatura de base a ser tomada como referência, normalmente a temperatura ambiente. 
- Segue-se com a quantificação dos fluxos de massa que cruzam a superfície de controle como: entradas de matérias-primas, elementos transportadores, combustíveis, ar de combustão e invasão de ar em zonas de pressão interna negativa; e saídas de produto acabado, escórias, elementos transportadores, produtos da combustão (determinando também sua composição) e fugas de gases em zonas de pressão interna positiva.

- De forma análoga, procede-se a quantificação dos fluxos de calor que cruzam a superfície de controle, levando-se em conta a temperatura de referência escolhida. Assim, os fluxos de calor mais evidentes são a entrada de combustível, a saída dos produtos da combustão, as perdas de calor superficiais, as perdas de calor por fuga de gases quentes em zonas de pressão positiva e a saída da carga aquecida. Porém também devem ser considerados outros fluxos de calor como a entrada do calor sensível do combustível, do ar de combustão, da carga e do elemento transportador quando preaquecidos acima da temperatura de referência e a perda de calor por radiação através de aberturas fixas ou temporárias.

$2^{\mathrm{a}}$ ) De posse das informações colhidas no campo, torna-se possível a realização dos cálculos. Embora as medições de campo devam ser colhidas observando-se o melhor critério de confiabilidade estatística, é pouco provável que esta premissa seja plenamente atendida pelos seguintes motivos:

- As medições dos diferentes parâmetros nem sempre são realizadas simultaneamente, como análise dos produtos da combustão (composição e temperatura), temperaturas superficiais do equipamento, temperatura do processo, temperatura ambiental, consumo de combustível, vazão de fuga de gases quentes em zonas de pressão positiva, invasão de ar falso em zonas de pressão negativa, temperaturas e umidade de entrada e saída do produto.

- As condições climáticas, como temperatura ambiente, umidade, vento etc., variam significativamente alterando os fluxos de calor através das superfícies, tornando instável o consumo energético do processo.

- As demandas da produção não costumam ser estáveis por motivos de mercado e diferentes mix de produtos.

- As matérias-primas também podem sofrer alterações como composição, qualidade e umidade, acarretando em menor ou maior consumo específico de energia. 
- As diferentes equipes nem sempre operam os processos de forma idêntica.

Portanto, para que o balanço energético apresente resultados confiáveis e representativos, é necessário aplicar a estratégia adequada a cada caso. Em primeiro lugar, o processo deve estar operando da forma mais representativa do mix de produção. Caso não haja uma situação representativa, devem ser realizados balanços térmicos para cada uma das situações mais significativas. Os processos térmicos contínuos mantêm seus parâmetros mais estáveis, facilitando a coleta de dados. Já os processos do tipo batelada exigem um número maior de medições ao longo do ciclo produtivo, devido às constantes variações de potência dos queimadores e das variações de temperatura nos produtos da combustão e na estrutura do equipamento térmico.

Após a contabilização dos parâmetros envolvidos no balanço de massa e de energia, verificase que, dificilmente, este último consegue igualar as entradas e saídas de calor, impossibilitando seu fechamento com exatidão. Em qualquer situação, existem três alternativas clássicas para solucionar o problema:

- Quando as saídas de calor apresentam valores inferiores às entradas e esta diferença não atinge $5 \%$ (critério adotado pelo autor por sugestão do eng. Andrew Kenneth Brierley da FEC em 1979), ela pode ser lançada como perdas não contabilizadas.

- Diferenças mais significativas do que a indicada no item anterior exigirão a revisão do estudo e, provavelmente, nova coleta de dados.

- Em algumas situações onde, garantidamente, apenas uma variável apresente incerteza quanto aos seus valores, este item pode ser inferido por diferença de modo a possibilitar o fechamento do balanço térmico. Por exemplo, as perdas térmicas superficiais de um forno podem variar significativamente com o fator vento e ação de intempéries como temperatura ambiente, umidade e ação direta da chuva.

\subsubsection{Aspectos de calor e trabalho}

Agora a Primeira Lei da Termodinâmica será tratada envolvendo calor e trabalho.

A formulação matemática da Primeira Lei, aplicada a um sistema percorrendo um ciclo termodinâmico, conforme Van Wylen e Sonntag (1973) é: “A integral cíclica do calor é proporcional à integral cíclica do trabalho". 
Ou seja:

$\oint \delta Q=\oint \delta W$

Os valores das integrais se igualam quando o calor e o trabalho são expressos na mesma unidade com, por exemplo, quilowatt hora $(\mathrm{kWh})$ ou Joule $(\mathrm{J})$. Caso contrário, deverá ser aplicado um fator de correção.

Shvets et al. (1975) citou a Primeira Lei com o seguinte enunciado: "É impossível criar um motor de movimento perpétuo (moto perpétuo) de primeiro tipo, isto é, um dispositivo de atuação perpétua o qual produziria trabalho sem consumir energia externa."

\subsubsection{Energia e eficiência energética}

O conceito de eficiência ou rendimento energético $(\eta)$ baseia-se na Primeira Lei. Para determinar essa eficiência em um sistema aberto é necessário fazer o balanço de massa e o balanço de energia que entra e sai do volume de controle, constituindo o balanço térmico. Segundo Pellegrini et al. (2005):

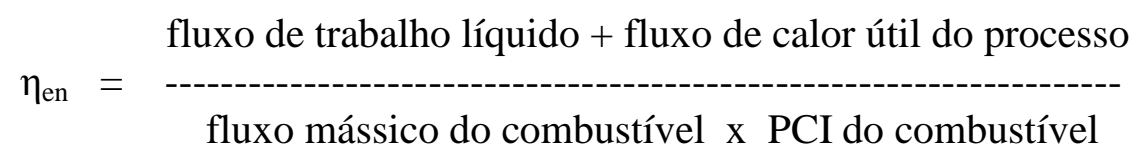

onde:

fluxo de energia fornecida $=$ fluxo mássico do combustível x PCI do combustível

Não havendo realização de trabalho, a fórmula fica:

$$
\eta_{\mathrm{en}}=\frac{\text { fluxo de calor útil do processo }}{-----------}
$$

$\mathrm{ou}$

$$
\begin{aligned}
& \text { fluxo de energia fornecida - fluxo das perdas de calor do processo }
\end{aligned}
$$

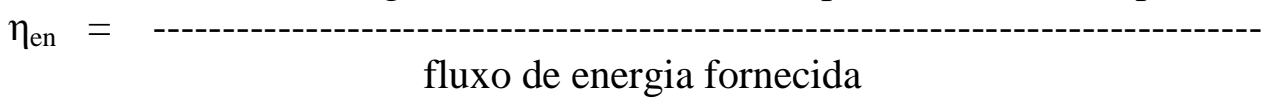




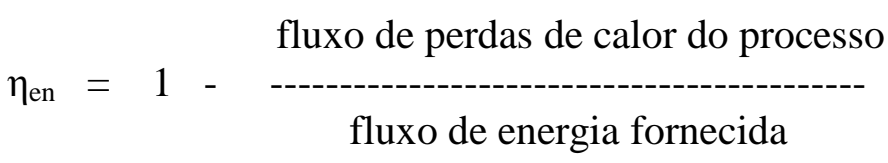

A Figura 10 mostra este conceito aplicado a um sistema aberto e seu volume de controle, considerando regime permanente, sendo nula a variação de energia interna do sistema, quer dizer, o sistema não armazena nem cede energia.

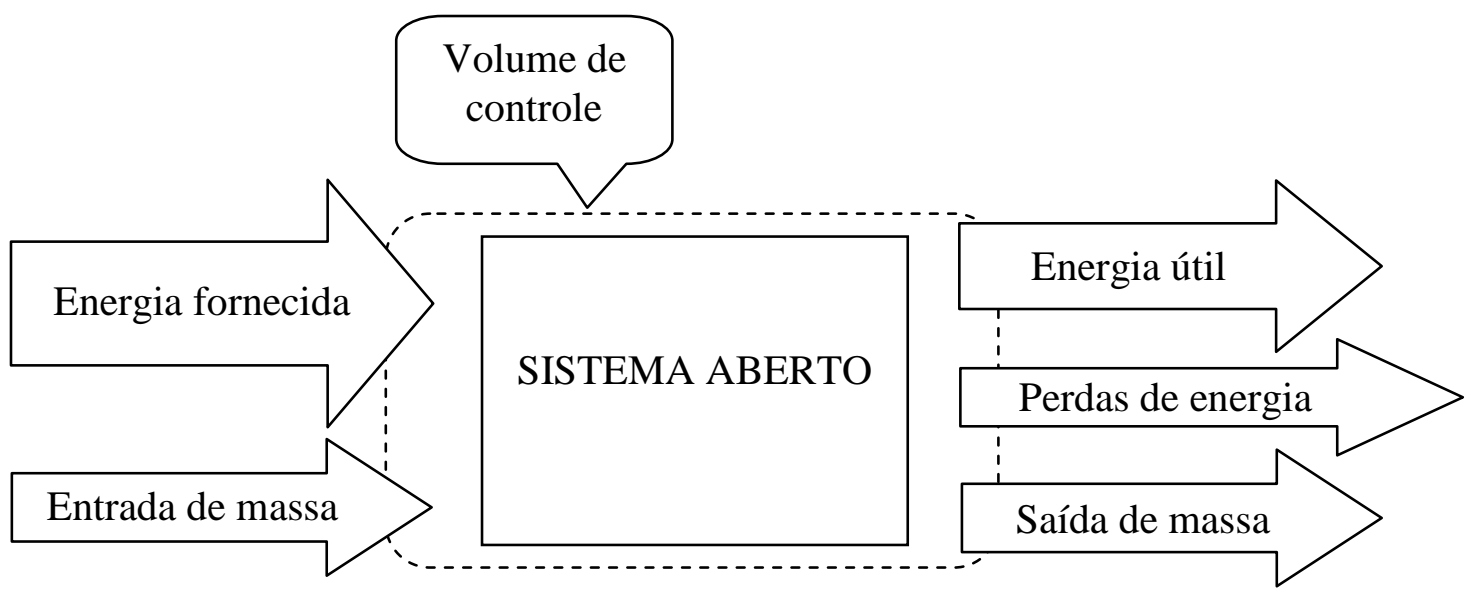

Figura 10 - Fluxo de massa e energia em sistema aberto e volume de controle

Fonte: elaboração própria

Porém é necessário definir claramente os termos utilizados na Figura 10.

Energia fornecida é o somatório de todas as entradas de energia no volume de controle, como energia elétrica, combustíveis e tudo mais que estiver com temperatura acima da temperatura de base do balanço térmico (normalmente a temperatura ambiente), como: carga preaquecida; combustível e comburente preaquecidos.

Energia útil é a energia efetivamente agregada ao produto e subprodutos do sistema. Algumas vezes esse conceito pode apresentar interpretações diferentes. Por exemplo, no caso do balanço térmico de um alto-forno, a energia útil poderia ser considerada apenas àquela incorporada ao ferro gusa ou então à soma das energias incorporadas ao ferro gusa e à escória, já que este subproduto é dotado de valor, sendo vendido às cimenteiras como matéria prima para fabricação de cimento.

E a energia perdida é o somatório de todas as perdas através da superfície de controle. Dependendo da filosofia de operação de um equipamento, que pode ser contínua ou intermitente, alguns tipos de perdas energéticas são específicos a cada situação. As perdas de calor comumente encontradas, no caso de fornos a combustível, são: 
- Calor perdido nos produtos da combustão estequiométrica;

- Calor perdido no excesso de ar de combustão;

- Calor perdido em frações combustíveis não queimadas, como monóxido de carbono, fuligem e hidrocarbonetos;

- Calor perdido no ar que se infiltra em zonas de pressão negativa e não participa do processo de combustão, mas sai aquecido junto com os gases da combustão;

- Calor perdido nas fugas de produtos da combustão através de aberturas situadas em zonas de pressões positivas, antes que tais produtos consigam trocar todo o calor disponível com a carga do forno;

- Calor perdido pela radiação da chama através de aberturas na estrutura do forno, sejam estas contínuas ou temporárias;

- Calor perdido através das superfícies do forno.

No caso de processos contínuos deve-se considerar ainda o calor perdido através dos elementos de transporte da carga no interior do forno, como esteiras, vagonetas, ganchos etc. No caso de processos intermitentes, onde existe variação da energia contida no interior do volume de controle, ocorre em particular a perda do calor armazenado na estrutura do equipamento durante a corrida e sua perda no final do ciclo. Estas perdas podem ser minimizadas operando-se o processo de forma ininterrupta, ou seja, uma batelada seguindo-se à outra de forma consecutiva, evitando ao máximo as variações de temperatura e, consequentemente, a perda de calor estrutural.

Existe ainda outro conceito de mesmo gênero, chamado "eficiência de combustão", que pode ser definido como a energia líquida fornecida ao equipamento térmico, ou seja, a fração da energia total fornecida pelo combustível cedida ao equipamento. Ou seja, considerando-se apenas a energia cedida pelo combustível e a energia contida nos produtos da combustão perdida na exaustão do equipamento, não levando em conta as demais perdas térmicas do equipamento.

Sua fórmula pode ser definida por:

$$
\begin{aligned}
\eta_{\text {СOMB }} & \left.=\left(\mathrm{Q}_{\mathrm{COMB}}-\mathrm{Q}_{\mathrm{PC}}\right) / \mathrm{Q}_{\mathrm{COMB}}\right) \\
\text { ou } \quad \eta_{\mathrm{COMB}} & \left.=1-\left(\mathrm{Q}_{\mathrm{PC}}\right) / \mathrm{Q}_{\mathrm{COMB}}\right)
\end{aligned}
$$


onde: $\eta_{\text {COMB }}$ é a eficiência de combustão

Q

QPC é o calor perdido na exaustão dos produtos secos e úmido da combustão

O calor dos produtos da combustão perdido na exaustão é calculado a partir da quantidade de combustível alimentado ao forno e da análise dos produtos da combustão (temperatura e composição). Desta forma, ao excesso de ar de combustão fornecido pelos queimadores irá se somar o eventual ar infiltrado no forno em zonas de pressões negativas, caso existam aberturas para tal. Assim, deverá ser considerado o calor perdido nos produtos da combustão estequiométrica $\left(\mathrm{CO}_{2}, \mathrm{H}_{2} \mathrm{O}, \mathrm{N}_{2}\right)$, no excesso de ar de combustão $\left(\mathrm{N}_{2}\right.$ e $\left.\mathrm{O}_{2}\right)$ e nas frações combustíveis não queimadas como monóxido de carbono, hidrocarbonetos e fuligem.

Embora não pareça um conceito útil, a eficiência de combustão pode ser um instrumento de fácil aplicação quando se converte um equipamento térmico de um energético para outro, em condições tais que as perdas estruturais se mantenham constantes, o que ocorre na maioria dos casos.

A Figura 11 mostra as eficiências de combustão para gás natural, calculadas levando-se em conta a condição otimizada com excesso de ar de combustão típico de 5\%, sem a existência de produtos da combustão incompleta e sem a formação de $\mathrm{NO}_{\mathrm{X}}$, em função da temperatura dos produtos da combustão a partir do momento que deixam de trocar calor com o processo térmico. Foram considerados o gás combustível e o ar de combustão na temperatura inicial de $20^{\circ} \mathrm{C}$.

Nota-se que, na Figura 11, as eficiências de combustão são elevadas nos processos de baixa temperatura, nos quais os produtos da combustão têm a possibilidade de ceder seu calor para o processo térmico, saindo do equipamento em baixas temperaturas e vice-versa.

Os conceitos utilizados no Balanço de Energia Útil (MME, 2005), no qual se baseia este trabalho, são:

- Energia Final: energia recebida e consumida pela indústria.

- Energia Útil: energia estimada com base nos rendimentos do primeiro processo de transformação energética

- Assim:

Energia Final $=$ Energia Útil + Energia Perdida

Energia Perdida = Energia Não Recuperável + Potencial de Economia de Energia 


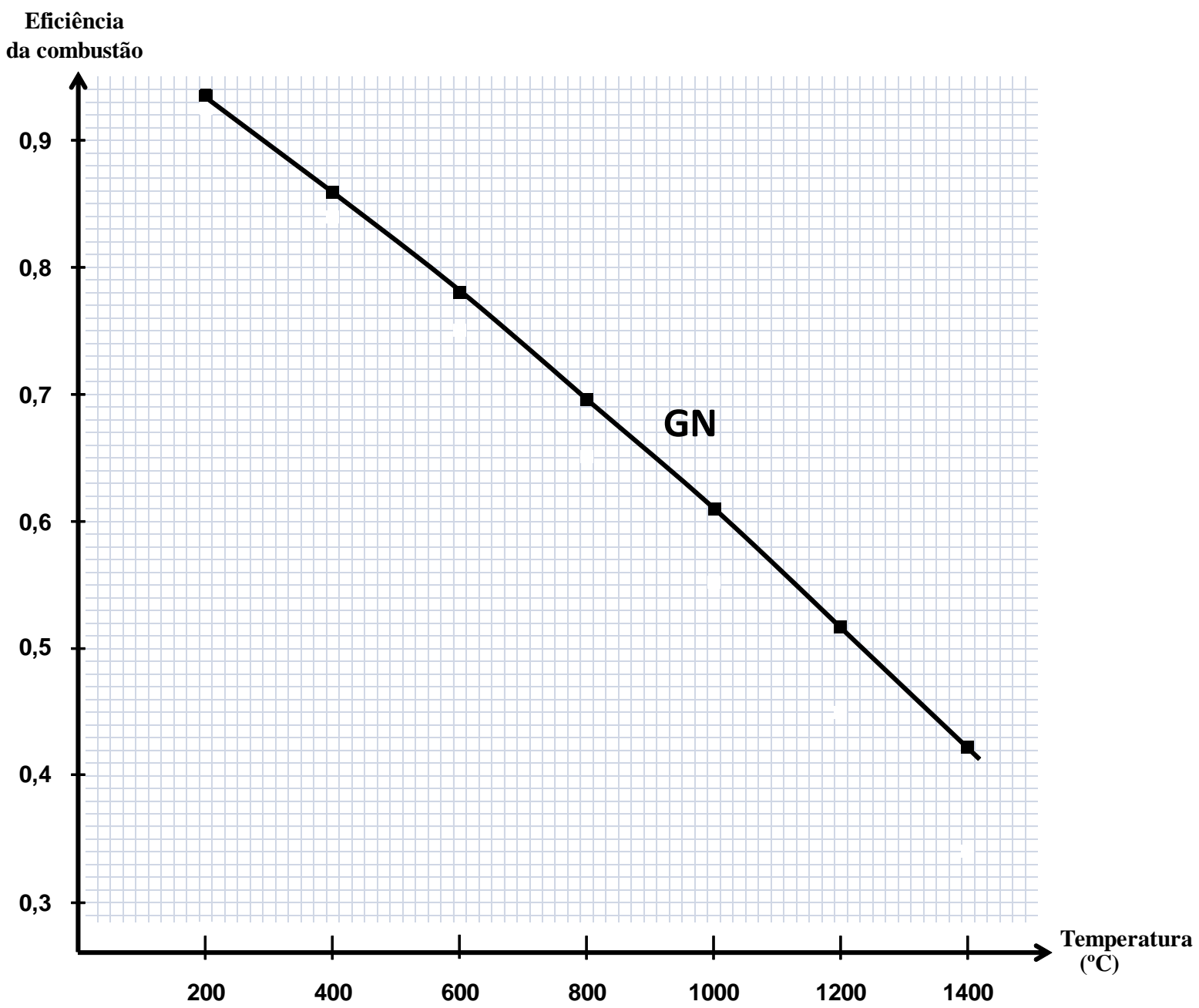

Figura 11 - Eficiências da combustão do GN em função da temperatura

Fonte: elaboração própria, dados calculados a partir do software "Beräkning av Termisk Verkningsgrad” AGA Aktiebolag - Suécia.

\subsubsection{Segunda Lei da Termodinâmica}

A Segunda Lei é conhecida também como a Lei da Entropia ou Princípio da Degradação da Energia. Seus dois enunciados clássicos se aplicam a máquinas térmicas, que transformam calor em trabalho, e a bombas de calor onde o trabalho executa transferência de calor.

O primeiro enunciado, de Kelvin-Planck, estabelece a impossibilidade da construção de uma máquina térmica cíclica que receba determinada quantidade de calor transformando-o em equivalente quantidade de trabalho. 
Assim, não existe máquina térmica que tenha o rendimento de $100 \%$. Ou seja, parte do calor recebido pela máquina térmica do reservatório quente sempre será rejeitado para um reservatório frio, conforme mostra a Figura 12.

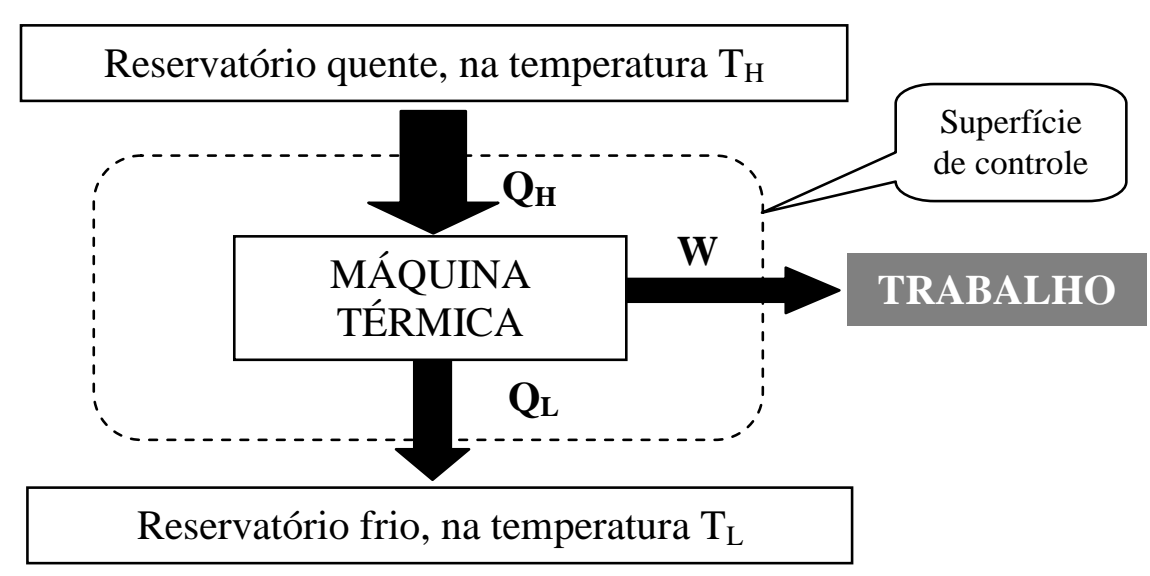

Figura 12 - Máquina térmica operando entre reservatórios quente e frio

Fonte: elaboração própria

O conceito de reservatório significa a existência de uma capacidade infinita, de forma que sua temperatura não se altere durante o processo de troca de calor.

Segundo a Primeira Lei, em relação ao volume de controle, e considerando que o sistema não acumula nem perde energia:

$$
\mathrm{Q}_{\mathrm{H}}=\mathrm{Q}_{\mathrm{L}}+\mathrm{W}
$$

De acordo com Carnot, o rendimento máximo das máquinas térmicas (reversíveis) depende tão somente das temperaturas do reservatório quente e do reservatório frio:

$$
\eta=\left(\mathrm{T}_{\mathrm{H}}-\mathrm{T}_{\mathrm{L}}\right) / \mathrm{T}_{\mathrm{H}}=1-\left(\mathrm{T}_{\mathrm{L}} / \mathrm{T}_{\mathrm{H}}\right)
$$

considerando as temperaturas em escala absoluta.

Portanto, o rendimento máximo aumenta com a elevação da temperatura do reservatório quente e com a redução da temperatura do reservatório frio. Geralmente elevar a temperatura do reservatório quente esbarra no limite de resistência dos materiais usados na construção da máquina térmica, tanto pelo fator tecnológico como pelos custos envolvidos. E a redução da temperatura do reservatório frio, normalmente o ar ou reservatórios de água (rios, lagos e oceanos), exigiria o consumo de energia como uma bomba de calor. 
As máquinas térmicas reais são irreversíveis, devido a fenômenos reais como atrito, expansão não resistida, troca de calor com diferença finita de temperatura e mistura de substâncias diferentes. Além das perdas termodinâmicas inevitáveis e da irreversibilidade das máquinas térmicas reais, existem limitações econômicas e tecnológicas que contribuem para baixar os rendimentos. Portanto, o rendimento das máquinas térmicas reais (irreversíveis) é expresso pela relação:

$$
\eta<1-\left(\mathrm{T}_{\mathrm{L}} / \mathrm{T}_{\mathrm{H}}\right)
$$

A Segunda Lei mostra claramente as limitações na conversão do calor para o trabalho, devido ao que poderia ser chamado de limitação da natureza, o que permite classificar a energia térmica como energia de baixa qualidade. Por outro lado, outras formas de energia que podem ser convertidas diretamente em trabalho, como a energia elétrica, são consideradas energias de alta qualidade.

De forma análoga à expressão de Carnot, que indica o rendimento máximo das máquinas térmicas reversíveis (Segunda Lei), a eficiência de combustão indica a eficiência máxima que poderia ser obtida pelos fornos a combustível de acordo com a Primeira Lei. Na realidade, em ambos os casos, os rendimentos máximos jamais poderão ser obtidos, servindo estes parâmetros apenas como um balizamento para os processos. 


\section{GASES COMBUSTÍVEIS}

O objetivo deste capítulo é apresentar os gases combustíveis, com enfoque naqueles disponíveis no Brasil, suas possibilidades e disponibilidades para a substituição da eletrotermia em aquecimento direto e calor de processo.

\subsection{Famílias de gases combustíveis}

Os gases combustíveis são classificados em três famílias. Na primeira família estão:

- biogases, oriundos da biogestão anaeróbica de matéria orgânica, como gás de aterro sanitário e gás de esgoto;

- gases manufaturados reformados (town gas, em inglês), produzidos no passado inicialmente a partir da hulha, posteriormente da nafta e, finalmente, do gás natural pelas duas primeiras distribuidoras de gás canalizado do Brasil, a CEG (controlada pela GÁS NATURAL FENOSA), na região metropolitana do Rio de Janeiro - RJ e a COMGAS (controlada pela COSAN) em São Paulo - SP;

- gás de coqueria (coke oven gás - COG, em inglês), conforme tratado no item 3.4;

- gás de síntese (syngas, em inglês), obtido por reforma a vapor de hidrocarbonetos;

- gás azul de água (blue water gas, em inglês), composto basicamente por hidrogênio e monóxido de carbono, obtido pela passagem de vapor d'água através de um leito de carvão mineral incandescente (HER MAJESTY'S STATIONERY OFFICE, 1969).

A segunda família é constituída por:

- gás natural, conforme tratado no item 3.2;

- misturas GLP-ar, com Índices de Wobbe na faixa do gás natural, também chamado GNS - Gás Natural Sintético, conforme tratado no item 3.4.

- DME - dimetil éter

E, a terceira família, é constituída basicamente pelos hidrocarbonetos de três e quatro átomos de carbono (ver item 3.3), comercializados sob as principais composições denominadas: 
- GLP ou Gás LP - Gás Liquefeito de Petróleo;

- Propano especial e propano comercial;

- Butano comercial e butano desodorizado;

- Propeno ou propileno, também comercializado sob outras denominações comerciais.

\subsection{Gás natural}

Gás natural é o gás combustível mais difundido e consumido em todo o mundo. Suas fontes podem ser subdivididas em dois grandes grupos: fontes convencionais, em formações associadas ou não ao petróleo; e fontes não convencionais como o gás obtido do xisto ou folhelho (shale gas), de jazidas de carvão (coal bed natural gas) e de formações de arenitos e calcários de baixa porosidade (tight gas).

O gás natural não convencional vem se desenvolvendo rapidamente nos Estados Unidos e sua viabilidade econômica, segundo U.S. Department of Energy (2009), tem sido devido aos avanços tecnológicos das perfurações horizontais, fraturamento hidráulico, associado às elevações de preço do gás natural no mercado mundial como resultado diretos das pressões da oferta e demanda, fazendo com que a produção de gás não convencional tivesse atingido o patamar de $46 \%$ da produção interna daquele país em 2009, com uma clara tendência de crescimento.

No Brasil, segundo Pires (2013), existem perspectivas de significativas para produção futura de gás não convencional pelo menos nas bacias onde já existem blocos concedidos, a saber: Parnaíba (MA), Recôncavo (BA), Parecis (MT) e São Francisco (MG).

Nas fontes convencionais de gás natural, sua produção se faz através de poços perfurados na crosta terrestre, em jazidas onde pode estar associado ou não ao petróleo. Geralmente o gás natural, oriundo de fontes convencionais ou não, é extraído do poço acompanhado de outros hidrocarbonetos mais pesados e, nesta condição, recebe a denominação de gás úmido. Essas umidades do gás natural recebem também a denominação de "riquezas do gás" por tratar-se de derivados nobres - gasolinas naturais e gases liquefeito do petróleo (GLP), que são separados em Unidades de Processamento de Gás Natural (UPGNs). Após a remoção das referidas riquezas, sua denominação passa a ser Gás Natural Seco, o qual é distribuído e comercializado sob a denominação de Gás Natural. Existem alguns raros poços onde o gás já se apresenta naturalmente seco, como nos poços de Chuchupa A e Chuchupa B, na região da 
Guajira, no litoral norte da Colômbia, onde o teor de metano é cerca de 98\%, de acordo com Becerra e Costa (2001).

A composição do gás natural seco varia de acordo com a jazida e com o processamento, podendo ser considerado basicamente metano, acompanhado de etano, e com frações residuais de propano, apresentando ainda traços de butano e hidrocarbonetos de cinco ou mais átomos de carbono denominados $\mathrm{C}^{+}$. Existe ainda a presença de outros gases, em pequenas percentagens, como oxigênio $\left(\mathrm{O}_{2}\right)$, nitrogênio $\left(\mathrm{N}_{2}\right)$, gás carbônico $\left(\mathrm{CO}_{2}\right)$, gás sulfídrico $\left(\mathrm{H}_{2} \mathrm{~S}\right)$ e hélio (He). Com respeito ao hélio, um gás nobre, inerte e raro, o gás natural é sua única fonte desde que economicamente viável. Segundo Ahlberg (1985), a viabilidade da produção de hélio exige que sua concentração no gás natural seja superior a $0,4 \%$ molar, sendo típicos os valores da ordem de $1,4 \%$. Porém, devido à crescente demanda mundial em relação à oferta, já se cogita o aproveitamento de hélio de jazidas de gás natural com teores acima de 0,1\%. No Brasil, as únicas jazidas que apresentaram até então hélio na composição do gás natural são os poços da região de Urucu na bacia amazônica.

A especificação do gás natural no Brasil é regulamentada pela Resolução $\mathrm{N}^{\circ} 16$ da Agência Nacional do Petróleo, Gás Natural e Biocombustíveis - ANP, de 17.06.2008 (ANP, 2008), conforme Tabela 2.

Observando-se na Tabela 2, com respeito ao poder calorífico superior especificado para a região Norte, sua faixa admite valores inferiores às demais regiões do país devido à maior presença de inertes, notadamente nitrogênio, na sua composição.

A utilização do gás natural no Brasil se iniciou na década de 1940, segundo registros da Petrobras UN-BA citados por Vieira et al. (2005), em um sistema dedicado a uma fábrica de cimento no Recôncavo Bahiano. Porém, o real desenvolvimento do gás natural iniciou-se com a construção do gasoduto conhecido como Nordestão na década dos 80 e do sistema da Bacia de Campos na década dos 90. Seu maior impulso foi a construção do Gasoduto Brasil- Bolívia - Gasbol, concluída sua primeira etapa em 1999, permitindo então a importação do gás boliviano. Outro passo muito importante foi a integração do sistema Sudeste-Nordeste, pela conclusão do gasoduto denominado Gasene em 2010, em seus três trechos:

- Cabiúnas (RJ) - Vitória (ES)

- Vitória (ES) - Cacimbas (ES)

- Cacimbas (ES) - Catu (BA) 
A construção do Gasene permitiu a alimentação com gás natural no novo sistema integrado a partir das UPGNs de Anchieta - ES e de Cacimbas (Linhares - ES).

Tabela 2 - Especificações do gás natural no Brasil

\begin{tabular}{|c|c|c|c|c|}
\hline \multicolumn{5}{|c|}{ TABELA DE ESPECIFICAÇÕES DO GÁS NATURAL } \\
\hline \multirow[b]{2}{*}{ CARACTERÍSTICA } & \multirow[b]{2}{*}{ UNIDADE } & \multicolumn{3}{|c|}{ LIMITES POR REGIÃO } \\
\hline & & Norte & Nordeste & $\begin{array}{l}\text { Centro-Oeste } \\
\text { Sudeste e Sul }\end{array}$ \\
\hline \multirow{3}{*}{$\begin{array}{c}\text { Poder calorífico superior a } \\
293,15 \mathrm{~K} \text { e } 101,325 \mathrm{kPa}, \\
\text { base seca }\end{array}$} & $\mathrm{kJ} / \mathrm{m}^{3}$ & 34.000 a 38.000 & \multicolumn{2}{|c|}{35.000 a 43.000} \\
\hline & $\mathrm{kcal} / \mathrm{m}^{3}$ & 8.121 a 9.172 & \multicolumn{2}{|c|}{8.360 a 10.270} \\
\hline & $\mathrm{kWh} / \mathrm{m}^{3}$ & 9,47 a 10,67 & \multicolumn{2}{|c|}{9,72 a 11,94} \\
\hline Índice de Wobbe, cálculo & $\mathrm{kJ} / \mathrm{m}^{3}$ & 40.500 a 45.000 & \multirow{2}{*}{\multicolumn{2}{|c|}{$\begin{array}{l}46.500 \text { a } 53.500 \\
11.106 \text { a } 12.778\end{array}$}} \\
\hline pelo PCS em base seca & $\mathrm{kcal} / \mathrm{m}^{3}$ & 9.673 a 10.748 & & \\
\hline Metano, mín. & $\% \mathrm{~mol}$ & 68,0 & \multicolumn{2}{|c|}{85,0} \\
\hline Etano, máx. & $\%$ mol & 12,0 & \multicolumn{2}{|c|}{12,0} \\
\hline Propano, máx. & $\% \mathrm{~mol}$ & 3,0 & \multicolumn{2}{|c|}{6,0} \\
\hline Butanos e superiores, máx. & $\%$ mol & 1,5 & \multicolumn{2}{|c|}{3,0} \\
\hline Oxigênio, máx. & $\% \mathrm{~mol}$ & 0,8 & \multicolumn{2}{|c|}{0,5} \\
\hline Inertes $\left(\mathrm{N}_{2}+\mathrm{CO}_{2}\right)$, máx. & $\% \mathrm{~mol}$ & 18,0 & \multicolumn{2}{|c|}{8,0} \\
\hline $\mathrm{CO}_{2}$, máx. & $\% \mathrm{~mol}$ & 3,0 & \multicolumn{2}{|c|}{3,0} \\
\hline Enxofre total, máx. & $\mathrm{mg} / \mathrm{m}^{3}$ & 70 & \multicolumn{2}{|c|}{70} \\
\hline Gás sulfídrico $\left(\mathrm{H}_{2} \mathrm{~S}\right)$, máx. & $\mathrm{mg} / \mathrm{m}^{3}$ & 10 & 13 & 10 \\
\hline $\begin{array}{c}\text { Ponto de orvalho da água } \\
\text { a } 1 \text { atm, máx. }\end{array}$ & ${ }^{\circ} \mathrm{C}$ & -39 & -39 & -45 \\
\hline $\begin{array}{l}\text { Ponto de orvalho de } \\
\text { hidrocarbonetos a } \\
\text { 4,5 MPa, máx. }\end{array}$ & ${ }^{\circ} \mathrm{C}$ & 15 & 15 & 0 \\
\hline
\end{tabular}

Fonte: ANP [2008]

Nesta tese foi considerado o poder calorífico inferior do gás natural indicado no Anuário Estatístico, ANP (2012): $8.800 \mathrm{kcal} / \mathrm{m}^{3} @ 1$ atm absoluta e $20^{\circ} \mathrm{C}$.

As perspectivas para expansão do uso do gás natural ganharam um alento extra com a descoberta das jazidas do pré-sal, tornando este gás como o energético mais indicado para a substituição da eletrotermia devido à sua disponibilidade, baixo custo na escala de consumo industrial e aspectos ambientalmente amigáveis. Porém existem ainda muitas restrições quanto à disponibilidade do gás natural no território brasileiro. Segundo Ferraro e Almeida (2006), os investimentos realizados na produção e no transporte de gás natural não vinham apresentando a devida contrapartida no segmento de distribuição devido à necessidade de grandes aportes de capital associados aos longos prazos de retorno e aos riscos envolvidos, 
situação essa que ainda perdura até o corrente ano. O Plano Decenal de Expansão de Energia 2021 - PDE 2021 (EPE/MME, 2013) prevê a oferta crescente de gás natural e as demandas, de acordo com as Figuras 13 e 14.

Na Figura 13, referente ao Brasil exceto região Norte, a oferta de gás natural leva em conta, por um lado, o decréscimo da produção dos campos descobertos e, por outro lado, a entrada das áreas em avaliação (recursos contingentes) e a descoberta de novos recursos. Além da importação do gás da Bolívia, considerada mantida na capacidade atual, a oferta do GNL poderá complementar, na medida das necessidades, a eventual demanda das termelétricas a gás. Para a oferta de GN na região Nordeste, o PDE 2021 (EPE/MME, 2013) prevê o declínio natural dos campos regionais existentes, mas também o acréscimo dos volumes dos campos superavitários do Espírito Santo e do novo terminal de regaseificação da Bahia programado para 2014. Nas regiões Sudeste, Sul e Centro-Oeste é esperado um significativo crescimento nas suas bacias offshore (Espírito Santo, Campos e Santos), além da ampliação do terminal de GNL na Baía de Guanabara. A partir de 2016 e 2017 está previsto haver excedente de GN, mesmo considerando a hipótese do atendimento à demanda termelétrica integral.

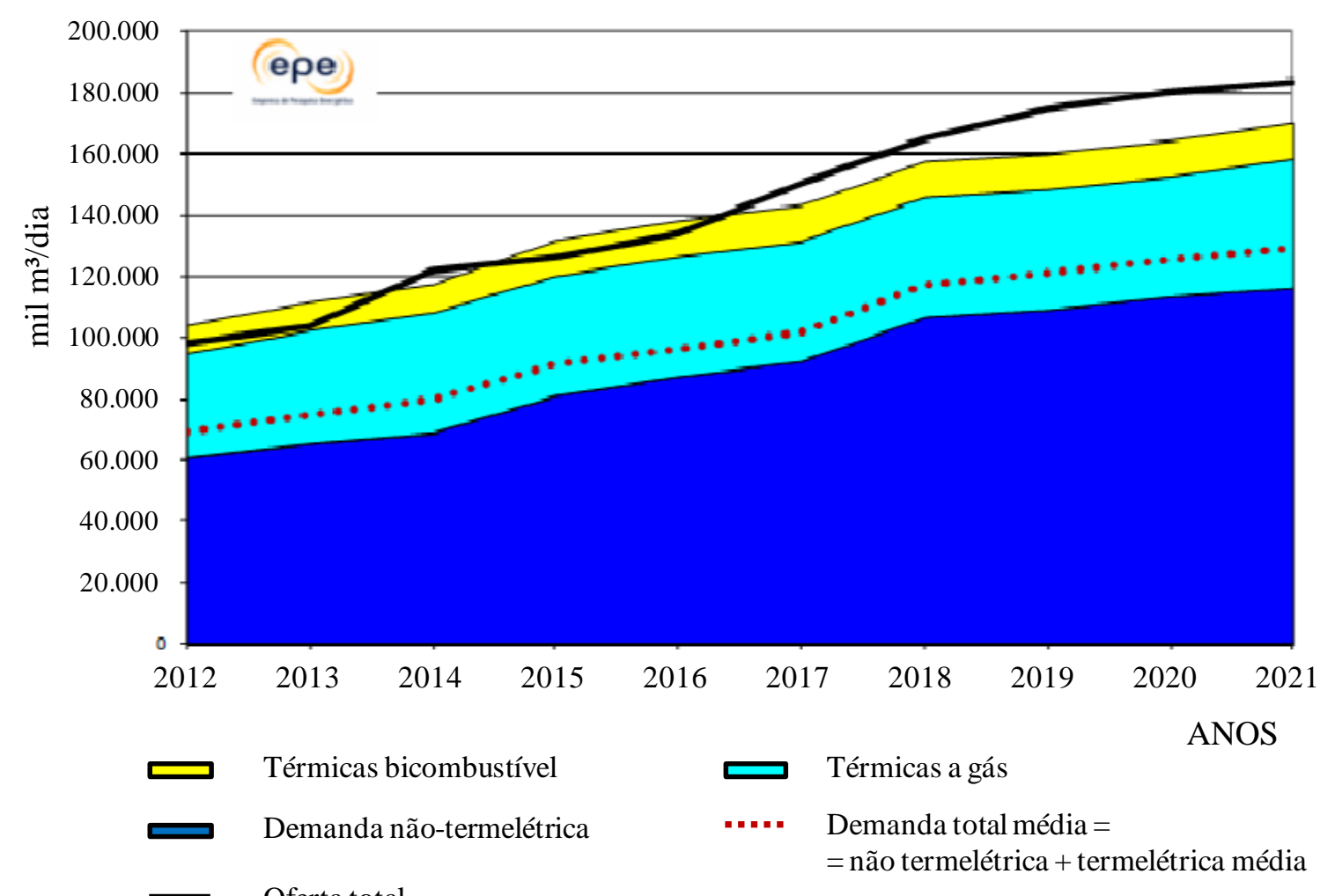

Figura 13 - Balanço de gás natural no Brasil - malha integrada

OBS.: o despacho médio termelétrico inclui tanto as térmicas a gás quanto as bicombustíveis; exclui a região Norte.

Fonte: MME (2013b). 
Na Figura 14, relativa à região Norte apenas por se tratar de um sistema independente, a oferta será mais do que suficiente para o atendimento à demanda, sendo sugerido pela EPE o desenvolvimento de estudos para a utilização da oferta excedente do gás natural.

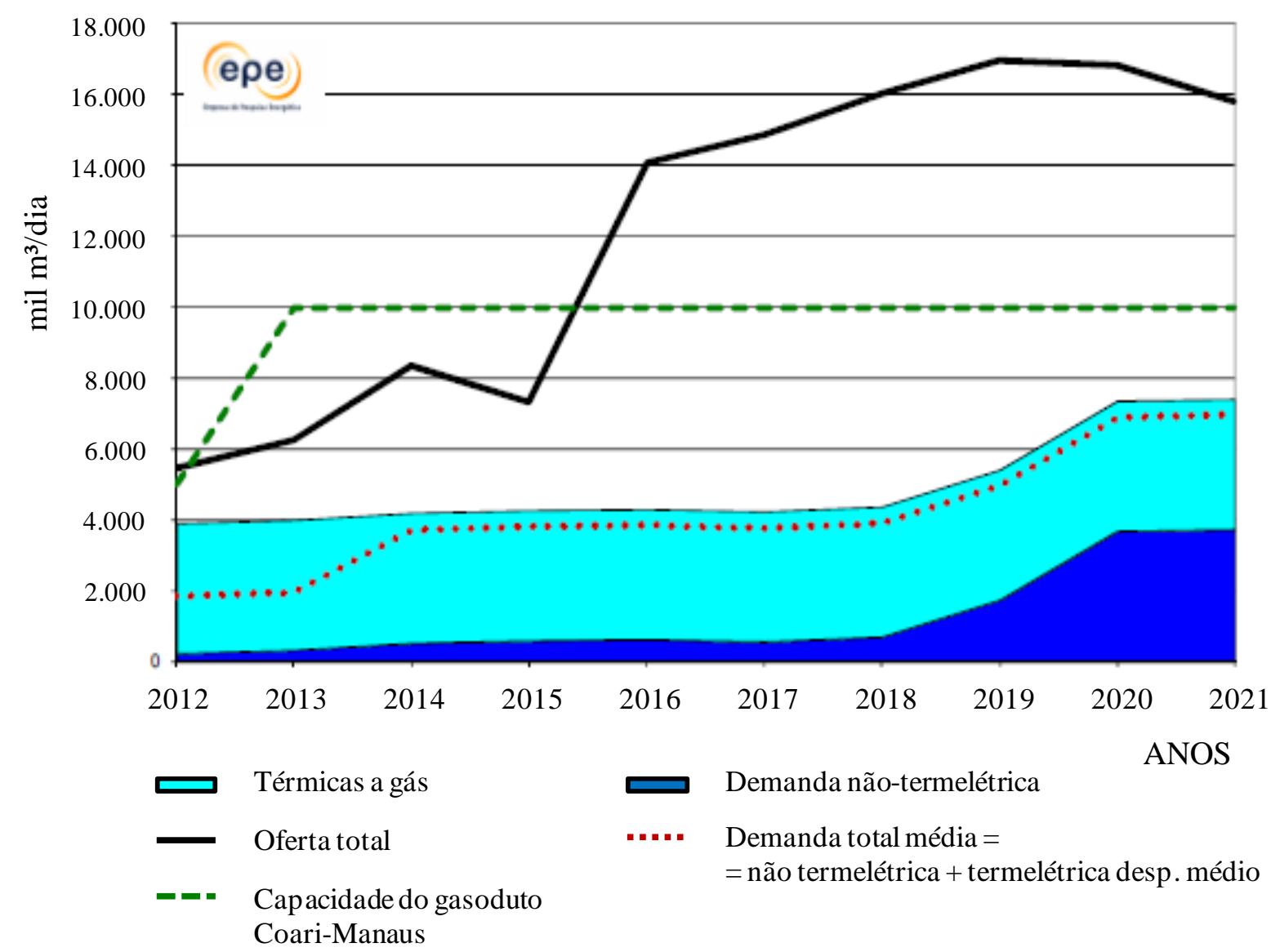

FIGURA 14 - Projeção do balanço de gás natural para a região Norte

Fonte: MME (2013b).

Além da distribuição do gás natural por gasodutos, é também possível fazê-lo por veículos e embarcações sob as modalidades comprimida em cilindros de alta pressão (150 a 250 bar). Essas características dificultam economicamente seu transporte rodoviário, pois o gás natural comprimido exige cilindros de alta pressão os quais, além de pesados, apresentam elevado custo de investimento.

A outra opção de distribuição é sob a modalidade criogênica, onde o gás natural se apresenta liquefeito na temperatura de $-161{ }^{\circ} \mathrm{C}$, conhecido pela sigla $\mathrm{GNL}$, de forma análoga à distribuição de oxigênio, nitrogênio e argônio. Para que o gás se mantenha nestas baixas temperaturas, tanto os tanques estacionários como os tanques montados sobre os veículos de 
distribuição necessitam de um isolamento térmico de excelente desempenho. Ainda assim, existe transferência de calor, ainda que lenta, do ambiente para a fase líquida do gás, o que acarreta no aumento de pressão devido à regaseificação ou ebulição, conhecida pelo termo na língua inglesa boil off, culminando na abertura da válvula de segurança do recipiente e, assim, aliviando a pressão excessiva do gás para a atmosfera. Este fato restringe tanto o tempo de estocagem em tanques estacionários, quando não há consumo de gás, como o tempo de transporte rodoviário, impondo limites geográficos na área de distribuição.

\subsection{Gás liquefeito de petróleo}

O gás liquefeito de petróleo é conhecido vulgarmente pela denominação de gás de cozinha, devido à sua larga comercialização através do tradicional botijão de 13 quilogramas de gás e de botijões de outras capacidades. Além disso, o GLP é comercializado através de centrais de gás abastecidas no local, em aplicações residenciais, comerciais e industriais.

Sua sigla GLP ( $L P G$, em inglês) está sendo alterada mundialmente para Gás LP ( $L P$ Gas, em inglês), por uma ação iniciada pela WLPGA - World LP Gas Association há alguns anos. O Brasil é um dos países que mais comercializam GLP no mundo e, segundo o Sindicato Nacional das Empresas Distribuidoras de Gás Liquefeito de Petróleo - SINDIGÁS, sua rede de distribuição abrange $100 \%$ dos municípios, totalizando mais lares do que a rede de energia elétrica.

Os Gases Liquefeitos de Petróleo normalmente comercializados no Brasil estão definidos na Resolução ANP No 18 de 02.09.2004, DOU de 06.09.2004 (ANP, 2004), em seu Artigo 2o, itens I a IV:

I. Propano Comercial - é a mistura de hidrocarbonetos que contem, predominantemente, propano e/ ou propeno.

II. Butano Comercial - é a mistura de hidrocarbonetos que contem, predominantemente, butano e/ ou buteno. Por ser um gás liquefeito de baixas pressões, é o principal componente das misturas gasosas destinadas às aplicações de propelente em aerossóis, agente espumante na produção de espumas plásticas e isqueiros.

III. Propano / Butano - é a mistura de hidrocarbonetos que contem, predominantemente e em percentuais variáveis, propano e/ou propeno e butano e/ou buteno. Esta mistura é o GLP normalmente comercializado nos botijões de $13 \mathrm{~kg}$ e recipientes de maior capacidade, nas aplicações convencionais de queima para simples geração de calor, encontradas nas residências, comércios e indústrias. Além disso, o GLP também pode ser utilizado como combustíveis para motores do ciclo Otto, em substituição à gasolina, ao etanol ou ao GNV; no Brasil, o uso para fins automotivos só está autorizado para empilhadeiras de acordo com a Resolução ANP $\mathrm{n}^{\circ} 15$ de 18.05.2005 em seu Art. 30, inciso II, por motivo de salubridade nos ambientes interiores onde tais veículos também trafegam. 
IV. Propano Especial - é a mistura de hidrocarbonetos que contem, no mínimo, 90\% de propano em volume e, no máximo, $5 \%$ de propeno em volume. Este propano é conhecido internacionalmente como Propano HD-5 e se destina a aplicações especiais onde a estabilidade da composição dos produtos da combustão seja exigível como, por exemplo, a geração de atmosferas protetoras para tratamentos térmicos de metais e alguns processos de metalização de superfícies por projeção térmica.

A composição do GLP (mistura propano / butano) é também citada na Ficha de Informação de Segurança de Produtos Químicos - FISPQ (PETROBRAS, 2011), em seu item 3, a saber:

$\begin{array}{ll}\text { Propano: } & 40-60 \%(\mathrm{v} / \mathrm{v}) \\ \text { Butano: } & 40-60 \%(\mathrm{v} / \mathrm{v}) \\ \text { Etano e mais leves: } & \text { máximo } 15 \% \\ \text { Pentano e mais pesados: } & 0,5 \text { a } 2,0 \%\end{array}$

Na composição apresentada pela FISPQ foi omitida a citação do propeno e dos butenos, os quais certamente estão incluídos nas percentagens indicadas para os componentes propano e butano respectivamente. Além disso, existe uma incoerência entre estas percentagens apresentadas pela FISPQ e a definição do GLP (mistura propano-butano) no item III da citada Resolução ANP No 18 (ANP, 2004) e no seu ANEXO I - Regulamento Técnico ANP No 2/2004, pois nestes dois últimos documentos não há nenhuma indicação quanto às percentagens dos componentes de três e quatro átomos de carbono. Analisando as análises cromatográficas em fase gasosa realizadas pela Cia. Ultragaz S.A. em seu laboratório na base de Mauá - SP, verifica-se que as percentagens citadas na FISPQ, quanto ao propano e ao butano, nem sempre são respeitadas. Mas quanto às percentagens de etano e mais leves (máximo $15 \% \mathrm{v} / \mathrm{v}$ ), e pentano e mais pesados (0,5 a 2,0\% v/v), tais limites são cumpridos. Porém, na prática, tais variações pouco ou nada influenciam na grande maioria das aplicações do GLP, tanto nas indústrias, como no comércio e nas residências, desde que as instalações estejam corretamente dimensionadas, principalmente quando o gás apresentar elevados teores de butanos e butenos.

Nesta tese foi considerado o poder calorífico inferior do GLP indicado no Anuário Estatístico da ANP (ANP, 2012): $11.100 \mathrm{kcal} / \mathrm{kg}$.

Quanto à sua disponibilidade no mercado brasileiro, as previsões feitas no PNE 2030 pela EPE/MME (2007), com a base de dados tomada em 2005, indicavam que a autossuficiência do GLP ocorreria por volta de 2010. Porém a realidade mostrou que a autossuficiência foi 
postergada devido a um aumento contínuo das importações de GLP de forma a complementar a produção nacional para atender à demanda, conforme indicado pela Figura 15.

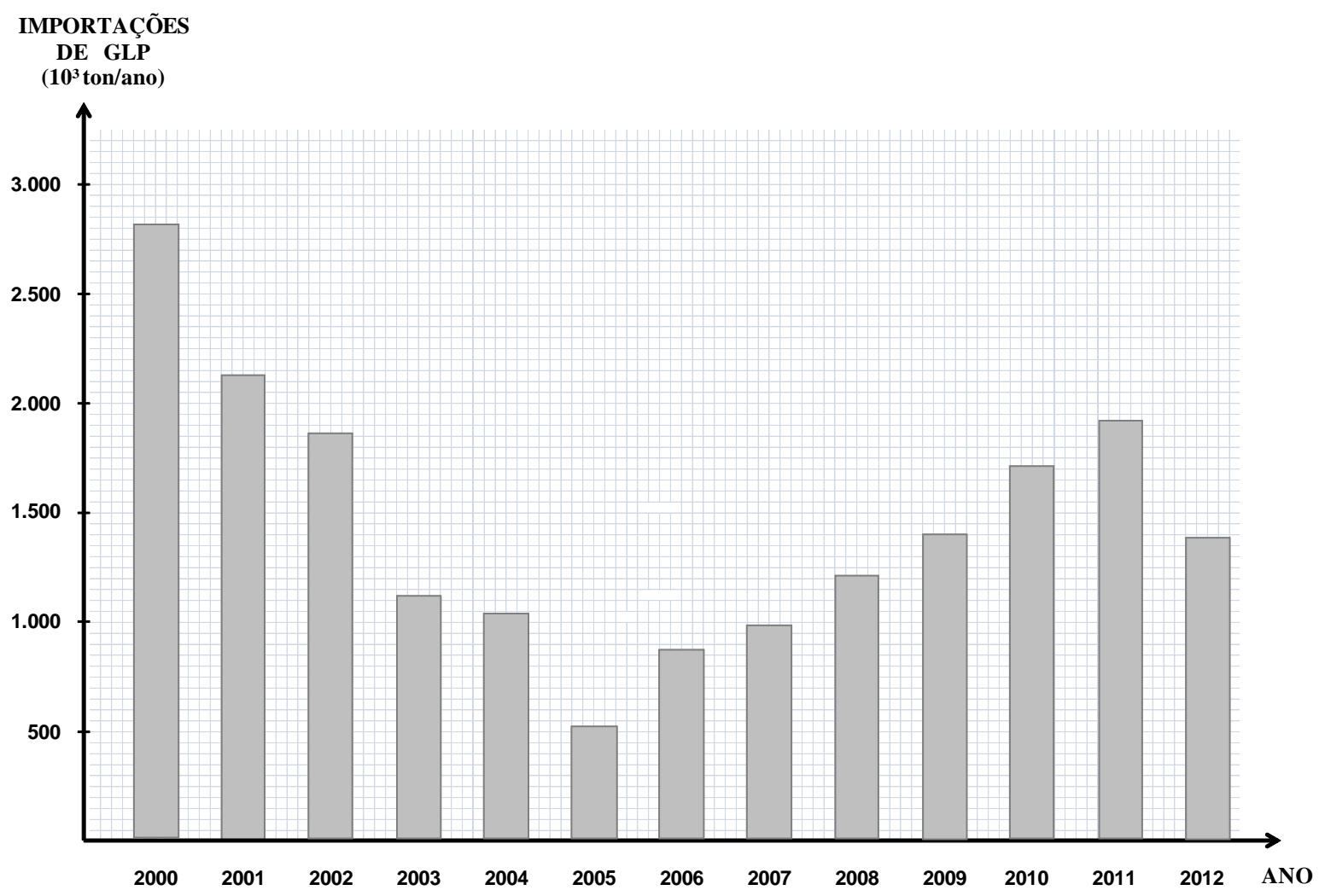

Figura 15 - Importações de GLP, de 2000 a 2012

Fonte: elaboração própria; www.anp.gov.br

Os motivos alegados são vários, desde a entrada em operação do complexo integrado gás químico Rio Polímeros S.A. em Campos Elíseos, Duque de Caxias - RJ que, além do etano também utiliza o propano como matéria-prima para produção de eteno, propeno e polietileno, até o atraso da entrada em operação de unidades de processamento do gás natural - UPGNs. A Figura 16 foi elaborada a partir dos dados informados no PDE 2021, prevendo a autossuficiência em GLP por volta de 2017 e um excedente da ordem de 1.000 .000 toneladas por ano a partir de 2018. Portanto deverá haver oferta de GLP suficiente para que a ANP libere alguns usos que ainda são proibidos, como caldeiras, aquecimento de piscinas e de saunas, além do uso automotivo (exceto empilhadeiras) e motores estacionários. Certamente haverá também GLP disponível para o uso nobre que é a substituição de eletrotermia. 


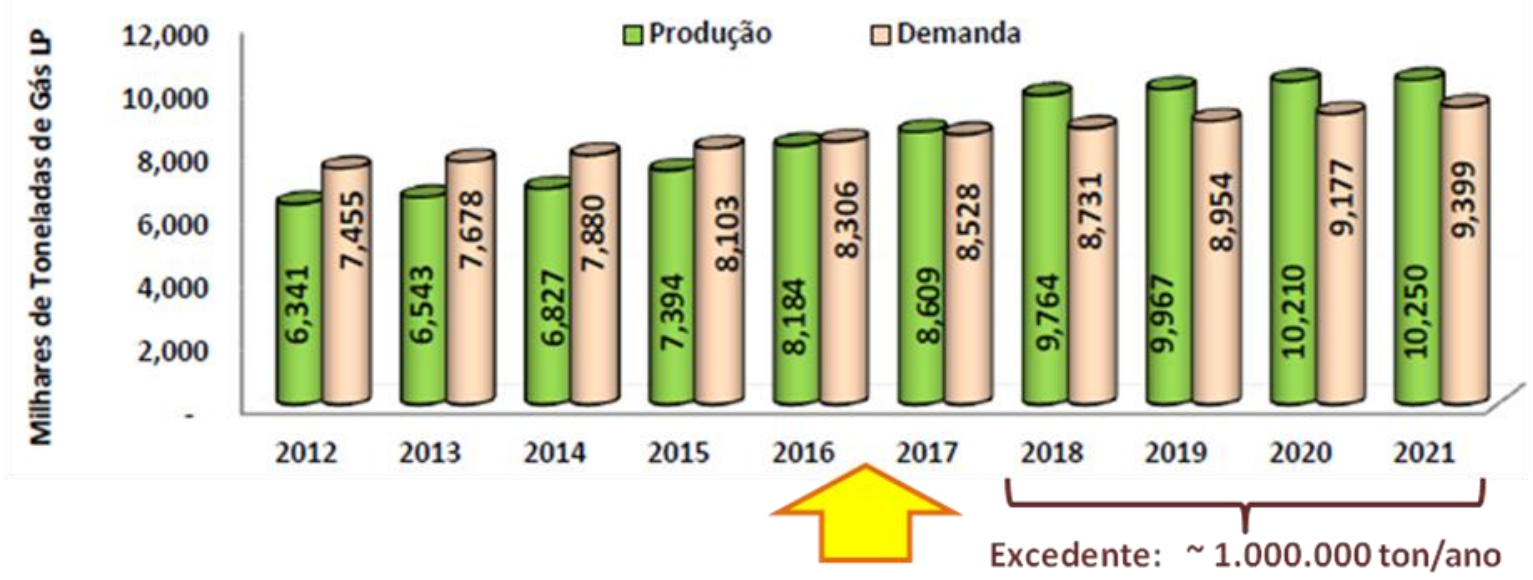

Figura 16. Produção e demanda de GLP (2012-2021)

OBS.: considerada a densidade de $0,555 \mathrm{t} / \mathrm{m}^{3}$ fase líquida para o GLP

Fonte: PDE 2021 - MME/EPE, 2012, apud SINDIGÁS

A conhecida denominação do GLP como gás de cozinha não faz jus às suas inúmeras aplicações na área industrial, que vão muito além da sua utilização como combustível em queimadores e motores a explosão. O GLP é ainda utilizado em incontáveis aplicações como:

- Matéria-prima para geração de gases redutores para proteger a carga ou aumentar o potencial de carbono em atmosferas de fornos de tratamento térmico;

- Matéria-prima para a indústria petroquímica, na produção de polímeros e de aditivos para elevação da octanagem em gasolinas;

- Agente espumante para formação de espumas de polímeros;

- Lubrificante em processos de alta temperatura pela deposição de estruturas de carbono com formação agregada de grafite;

- Desmoldante por recobrimento a quente de superfícies com um filme de fuligem de baixíssima espessura;

- Propelente em aerossóis, substituindo os compostos de clorofluorcarbono, denominados pela sigla CFC.

Além dessas aplicações, pouco conhecidas do público em geral, o GLP também pode ser utilizado juntamente com outros gases combustíveis, a saber: 
- Substituição de gás natural, em caso de falha no sistema de transmissão e distribuição ou backup no caso de contratos de fornecimento com claúsula interruptível, sendo aplicado diretamente no processo industrial (queimadores duais) ou através das misturas GLP-ar, conhecidas também como ar propanado.

- Enriquecimento de gás natural ou de gás de coqueria com GLP para controlar eventuais variações de poder calorífico, em locais onde ocorram flutuações devido ao abastecimento a partir de fontes com composições distintas.

- Enriquecimento de gás de alto-forno (GAF) com GLP para elevar seu poder calorífico e, consequentemente, sua temperatura de chama, tornando viável sua utilização em processos térmicos onde, originalmente, não seria possível.

- Enriquecimento do gás produzido em gaseificadores de lenha ou carvão vegetal com GLP para elevação e estabilização do poder calorífico, principalmente quando aplicado em processos de alta temperatura, aplicação esta desenvolvida no Brasil após a segunda crise do petróleo, notadamente na indústria cerâmica.

- Enriquecimento da corrente de gás natural com GLP no processo de obtenção de gás redutor, obtido por reforma a vapor, com o objetivo de elevar o teor de monóxido de carbono $(\mathrm{CO})$ em relação ao teor de hidrogênio $\left(\mathrm{H}_{2}\right)$, quando esta alteração for benéfica ao processo como, por exemplo, no processo de redução direta de minério de ferro.

Sob o aspecto mercadológico, a disputa pela liderança do mercado nos últimos anos tem conduzido as distribuidoras de GLP à prática de margens baixíssimas para os novos consumos de grande porte no mercado industrial, tanto para as aplicações como combustível nas áreas não abastecidas pelo GN, como também matéria-prima para produtos petroquímicos como o EBTE e iso-octeno.

A Figura 17 mostra que o mercado nacional de GLP é dominado por quatro grandes distribuidoras, sendo a diferença de market share entre a primeira (Ultragaz) e a terceira (Supergasbras) de apenas 2,32\% tomando-se por base os dados disponibilizados pelo Sindigás referentes ao mês de janeiro de 2013. 


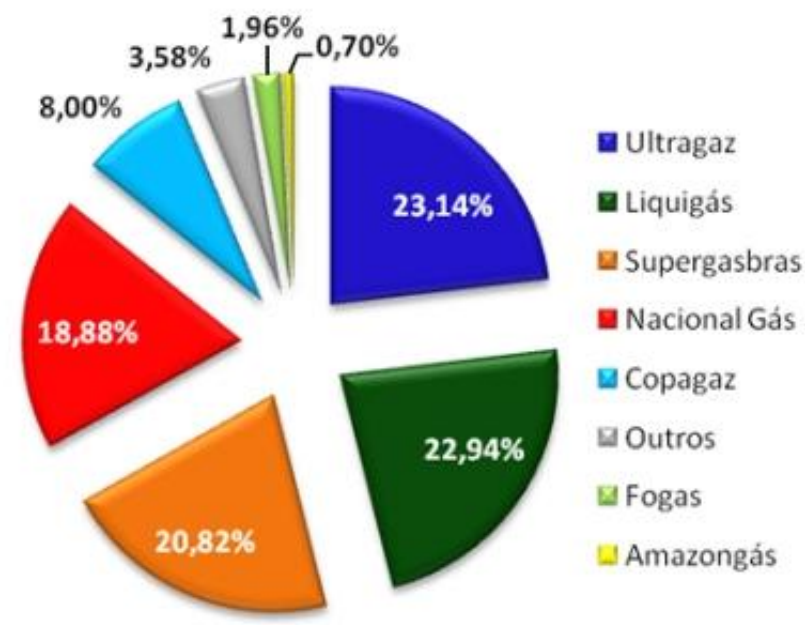

Figura 17 - Market share do mercado de GLP em janeiro de 2013

Fonte: site do SINDIGÁS (consulta em 03/06/2013)

\subsection{Gás natural sintético}

Denomina-se Gás Natural Sintético - GNS, também conhecido por Gás Natural Substituto ou ar propanado, às misturas de GLP com ar, cujo objetivo principal é antecipar, complementar ou substituir, em caso de indisponibilidade, o fornecimento de gás natural dispensando a necessidade de conversão dos queimadores ou da existência de queimadores duais.

Existem duas filosofias para se determinar as proporções GLP-ar utilizadas na preparação do GNS:

$1^{\text {a) }}$ a conservação do Índice de Wobbe do GN;

$2^{a}$ ) a conservação do poder calorífico do GN.

A conservação do Índice de Wobbe do GN (equação 9) é a mais comum, assumindo o objetivo da substituição ou complementação em equipamentos com fluxo de gás controlados por pressão, pois assim está garantida a mesma vazão térmica em quilocalorias por hora, dispensando a conversão dos queimadores de gás natural. Esta filosofia se aplica, sem restrições, à maioria dos queimadores encontrados nos domicílios e no comércio. E a mesma filosofia também é aplicável nas indústrias, porém torna-se necessário alterar alguns parâmetros quando o controle do processo de queima é realizado através das medições dos fluxos de gás combustível e comburente, pois a conservação do Índice de Wobbe não torna todas as características do GNS semelhantes à do gás natural que está sendo substituído, como 
indica a Tabela 3. Esta tabela permite a comparação das características do GN, do GLP e do GNS, percebendo-se que são significativamente distintas, onde o poder calorífico superior em base volumétrica exige o estabelecimento de uma nova parametrização dos fluxos de combustível no controle das vazões na ocasião da mudança de um gás para outro.

$\mathrm{W}_{\mathrm{S}}=\operatorname{PCS} /\left(\mathrm{d}_{\mathrm{ar}}\right)^{0,5}$

onde:

$\mathrm{W}_{\mathrm{S}}=$ Índice de Wobbe superior

PCS = poder calorífico superior

$\mathrm{d}_{\mathrm{ar}}=$ densidade relativa ao ar (adimensional)

Tabela 3 - Comparação das características do GN, GLP e GNS

\begin{tabular}{cccc}
\hline Gás & $\begin{array}{c}\text { PCS } \\
\left(\mathrm{kcal} / \mathrm{m}^{3}\right)\end{array}$ & $\mathrm{d}_{\mathrm{ar}}$ & $\begin{array}{c}\mathrm{W}_{\mathrm{s}} \\
\left(\mathrm{kcal} / \mathrm{m}^{3}\right)\end{array}$ \\
\hline GN & 9.400 & 0,636 & 11.770 \\
GLP & 26.798 & 1,878 & 19.555 \\
GNS & 14.257 & 1,467 & 11.770 \\
\hline
\end{tabular}

Fonte: Costa, F.C. (2009)

OBS.:

1) $\mathrm{m}^{3}$ considerado a $20^{\circ} \mathrm{C}$ e 1 atm abs

2) GLP considerado: $40 \%$ propano $+60 \%$ butano (molar)

3) Composição do GNS $=53,2 \%$ GLP $+46,8 \%$ ar

4) A unidade que expressa o Índice de Wobbe é a mesma unidade utilizada no poder calorífico, visto que a densidade relativa ao ar é adimensional; porém, os significados físicos das propriedades são diferentes.

Quando o GNS com mesmo Índice de Wobbe é injetado na rede de GN para complementar a demanda de gás, numa situação de peak shaving horário (geralmente subdimensionamento da rede de distribuição) ou peak shaving sazonal (complementação de oferta insuficiente no inverno), em uma situação onde as proporções de GN e GNS variem no tempo e/ou ao longo da rede, sendo as vendas aos consumidores realizadas por medições volumétricas, não é possível aplicar um preço justo devido às variações do poder calorífico. 
A solução encontrada pela empresa uruguaia Montevideo Gas (ex-GASEBA, atualmente sob controle acionário da Petrobras) no inverno foi complementar a demanda de gás com a mistura GLP-ar que conserva o mesmo poder calorífico do GN, evitando assim os referidos problemas de medição volumétrica para venda. Evidentemente, como a conservação do Índice de Wobbe não estaria sendo atendida, haveria uma restrição quanto à proporção máxima da injeção dessa mistura GLP-ar de forma que os queimadores não viessem a apresentar instabilidade de chama. O Eng. Gustavo Portas, que acompanhou esse projeto, informou que misturas volumétricas de GN com até 50\% de GNS com mesmo poder calorífico não apresentaram problemas de instabilidade.

Os custos do GNS serão sempre superiores aos custos do equivalente energético em GLP devido aos investimentos nos misturadores, nos compressores de ar e na instrumentação de controle, além dos custos operacionais e de manutenção. Existem alguns tipos de misturadores GLP-ar que dispensam o uso de compressores, sendo a admissão de ar feita pela depressão gerada pela passagem do fluxo de GLP em um venturi atmosférico. Porém estes misturadores mais simples, sem ar comprimido, geram um GNS de baixa pressão (inferior a 10 psig) e de composição menos estável, cuja aplicabilidade é restrita a poucos equipamentos como caldeiras, aquecedores de fluidos térmicos e secadores.

\subsection{Gás de coqueria}

O gás de coqueria (coke oven gas - COG em inglês) é obtido como subproduto do processo de coqueificação do carvão mineral, para se obter o coque metalúrgico, sendo liberado sob a forma de efluente gasoso aquecido. Trata-se de um gás de médio poder calorífico, podendo ser aplicado em processos térmicos de baixa a alta temperatura, porém sua utilização raramente ultrapassa os limites da siderúrgica ou das vizinhanças onde se situa a planta de coque.

Suas aplicações tradicionais nas siderúrgicas são: aquecimento de panelas, aquecimento de tundish, aquecimento de fornos de forjaria, laminação e tratamento térmico. Além destas existe ainda a possibilidade da aplicação do gás de coqueria na geração de energia em usina termelétrica, como no caso da nova coqueria da SunCoke instalada na área da Companhia Siderúrgica de Tubarão - CST, no município de Serra - ES.

Sua composição molar está apresentada na Tabela 4. 
Tabela 4 - Composição do gás de coqueria

\begin{tabular}{lcc}
\hline \multicolumn{3}{c}{ COMPOSIÇÃO DO GÁS DE COQUERIA } \\
\multicolumn{1}{c}{ Constituintes } & Fórmula & $\%$ molar \\
\hline Metano & $\mathrm{CH}_{4}$ & $28,3-29,0$ \\
Etano & $\mathrm{C}_{2} \mathrm{H}_{6}$ & $3,3-3,4$ \\
Propano & $\mathrm{C}_{3} \mathrm{H}_{8}$ & 0,2 \\
Monóxido de carbono & $\mathrm{CO}$ & $4,2-5,6$ \\
Hidrogênio & $\mathrm{H}_{2}$ & $50,6-55,4$ \\
Dióxido de carbono & $\mathrm{CO}_{2}$ & $0,9-1,4$ \\
Oxigênio & $\mathrm{O}_{2}$ & $0,4-1,6$ \\
Nitrogênio & $\mathrm{N}_{2}$ & $4,3-10,8$ \\
\hline
\end{tabular}

Fonte: Reed (1986).

\subsection{Gás de alto-forno}

O gás de alto forno (GAF), denominado Blast Furnace Gas (BFG) no idioma inglês, é um subproduto do processo de redução metalúrgica do minério de ferro, sendo coletado no topo dos altos-fornos. Sua maior desvantagem é o baixo poder calorífico, na faixa de 700 a 1.000 $\mathrm{kcal} / \mathrm{Nm}^{3}$, o que limita o seu aproveitamento ao âmbito da própria siderúrgica. Este baixo poder calorífico deve-se à elevada presença de gases inertes na composição (Tabela 5).

Tabela 5 - Composição do gás de alto-forno

\begin{tabular}{lcc}
\hline \multicolumn{3}{c}{ COMPOSIÇÃO DO GÁS DE ALTO FORNO } \\
\multicolumn{1}{c}{ Constituintes } & Fórmula & $\%$ molar \\
\hline Monóxido de carbono & $\mathrm{CO}$ & de 23 a 33 \\
Hidrogênio & $\mathrm{H}_{2}$ & de 1,5 a 3,5 \\
Nitrogênio & $\mathrm{N}_{2}$ & de 50 a 60 \\
Dióxido de carbono & $\mathrm{CO}_{2}$ & de 8 a 15 \\
\hline
\end{tabular}

Fonte: Her Majesty's Stationery Office (1969)

Sua aplicação mais comum é no aquecimento do ar de processo dos altos-fornos através de trocadores de calor recuperativos (glendons) ou trocadores de calor regenerativos (cowpers). Também pode ser aplicado em outros processos térmicos na própria siderúrgica, mas apresenta limitações de temperatura devido ao seu baixo poder calorífico, podendo ser aplicado em processos de até $650^{\circ}-760^{\circ} \mathrm{C}$ segundo Her Majesty's Stationery Office (1969). 
Além disso, o GAF está sempre acompanhado de materiais particulados oriundos do coque ou carvão vegetal, além de umidade, exigindo sua remoção antes da utilização em alguns processos que não admitam tais contaminantes. Por outro lado, alternativas podem ser aplicadas para possibilitar sua aplicação em processos que exijam temperaturas mais elevadas, como:

- Enriquecer o GAF com gases de poderes caloríficos mais elevados como gás de coqueria, gás natural ou GLP.

- Utilizar ar enriquecido com oxigênio ou, até mesmo, oxigênio puro.

- Preaquecer o ar de combustão.

- Preaquecer o GAF ou aproveitar seu calor sensível.

Em todas as alternativas citadas, o objetivo é a elevação da temperatura de chama de forma a torná-la compatível com a temperatura do processo. Dependendo da disponibilidade, o GAF pode ser utilizado para substituir a eletrotermia em fornos, ainda que necessite da complementação de outro gás combustível. O GAF excedente é conduzido para um flare pois, devido principalmente ao teor significativo de monóxido de carbono, não deve ser lançado na atmosfera sem queimar.

\subsection{Gás de refinaria}

Define-se gás de refinaria (GR) como o gás obtido no processo de refino do petróleo, apresentando composição variável de acordo com a origem do petróleo e seu processamento.

A Tabela 6 fornece a composição do GR disponível para a ampliação da antiga PQU, atual Quattor / Braskem. Os componentes encontrados em sua composição são o hidrogênio, o metano e correntes de hidrocarbonetos mais pesados. Suas aplicações raramente ultrapassam a fronteira da própria refinaria.

No passado, a COMGAS distribuiu o gás de refinaria em uma pequena rede dedicada na área de São José dos Campos - SP, nas proximidades da sua fonte geradora, a Refinaria Henrique Lage - REVAP.

A Tabela 6 mostra uma composição do gás de refinaria que estava disponível para a ampliação da Petroquímica União, fornecida pela ABIQUIM. 
Tabela 6 - Composição do GR disponível para ampliação da PQU

\begin{tabular}{lc}
\hline $\begin{array}{c}\text { COMPOSIÇÃO DO GÁS DE REFINARIA } \\
\text { Constituintes }\end{array}$ & \% massa \\
\hline Hidrogênio & 2 \\
Metano & 25 \\
Corrente $\mathrm{C}_{2}$ & 45 \\
Corrente $\mathrm{C}_{3}$ & 15 \\
Corrente $\mathrm{C}_{4}$ & 2 \\
Frações $\mathrm{C}_{5}^{+}$ & 1 \\
Outros & 10 \\
\hline
\end{tabular}

Fonte: ABIQUIM, 2003 apud Moreira (2008)

Obs.:

Os hidrocarbonetos indicados como Corrente $\mathrm{C}_{\mathrm{n}}$ referem-se àqueles que possuem " $\mathrm{n}$ " átomos de $\mathrm{C}$.

As Frações $\mathrm{C}_{5}{ }^{+}$significam hidrocarbonetos com 5 ou mais átomos de $\mathrm{C}$

\subsection{Gás de biodigestão anaeróbica}

O gás de biodigestão anaeróbica ou biogás é produzido pela decomposição de matéria orgânica em ambiente com ausência de oxigênio. Como exemplos, encontram-se o gás de aterro sanitário (Landfill Gas ou $L F G$, em inglês), o gás de biodigestores anaeróbicos e o gás de esgoto sanitário. Estes gases apresentam características semelhantes, onde a principal fração combustível é o metano, acompanhado de um teor significativo de gás carbônico e muitos outros componentes em pequenas percentagens. Seu poder calorífico situa-se na faixa de $4.000 \mathrm{kcal} / \mathrm{m}^{3}$, o que possibilita seu aproveitamento em processos térmicos residenciais, comerciais e industriais, como matéria-prima e na geração de energia elétrica. Porém a limitada disponibilidade restringe sua utilização nas proximidades da fonte geradora, como realiza a empresa Biogás Energia Ambiental S.A., no aterro Bandeirantes, que fornece biogás para a alimentação de conjuntos motogeradores. Caso o biogás não possa ser utilizado em nenhum processo, ele deverá ser obrigatoriamente queimado em flare, devido ao seu elevado teor de metano, o qual contribui significativamente para o aumento do efeito estufa quando não queimado. Por outro lado, sua incineração pode possibilitar a venda de créditos de carbono, gerando uma receita adicional para a empresa ou município.

A composição volumétrica do gás de biodigestão anaeróbica tem como principais componentes o metano (50\% - 70\%) e o gás carbônico (25\% a 50\%), acompanhados de gás sulfídrico, amoníaco, nitrogênio e outros micro componentes. 


\subsection{Dimetil éter}

$\mathrm{O}$ dimetil éter (DME), cuja fórmula química é $\mathrm{CH}_{3}-\mathrm{O}-\mathrm{CH}_{3}$, ou $\mathrm{C}_{2} \mathrm{H}_{6} \mathrm{O}$ é um gás combustível que começa a despontar como uma alternativa que, dependendo da sua matéria-prima, pode ser considerado com uma acentuada qualidade ecológica. Seu processo de obtenção pode ser feito através do gás de síntese, a partir de biomassa e de carvão mineral. No Brasil, sua produção é feita utilizando-se como matéria-prima o metanol, obtido a partir do gás natural. Seu poder calorífico inferior é de $6.837 \mathrm{kcal} / \mathrm{kg}$ (SEMELSBERGER, 2006) e pode ser liquefeito sob pressões moderadas, permitindo seu transporte e armazenagem nos mesmos vasos de pressão destinados aos gases liquefeitos de petróleo.

É possível ainda a utilização do DME puro ou em misturas com o GLP, pois suas propriedades físicas de armazenagem e ponto de ebulição são semelhantes, para utilização como gás combustível para aplicações residenciais, comerciais e industriais, inclusive para oxi-corte de ferrosos.

O DME pode também substituir total ou parcialmente o óleo diesel em motores de combustão interna, devido ao número (ou índice) de cetano de ambos os combustíveis apresentarem valores próximos conforme indica a Tabela 7. A grande vantagem da queima do DME em motores do ciclo diesel é a isenção de fuligem devido ao fato das moléculas deste gás não apresentarem ligações entre os átomos de carbono, havendo ainda um átomo de oxigênio entre eles o qual participa como comburente.

Tabela 7 - Números de cetano dos óleos diesel e do DME

\begin{tabular}{lccccc}
\hline \multirow{2}{*}{ COMBUSTÍVEL } & \multicolumn{4}{c}{ ÓLEO DIESEL (1) } & \multirow{2}{*}{ DME (2) } \\
& S 10 & S 50 & S 500 & S 1800 & \\
\hline Número de cetano & 48 (mín) & 46 (mín) & 42 (mín) & 42 (mín) & 55 a 60 \\
\hline
\end{tabular}

Fontes: elaboração própria

(1) Site da Petrobras Distribuidora

(2) Site da IDA - International DME Association

O DME pode ainda, em mistura com o GLP, ser aplicado em motores do ciclo Otto, até o teor máximo de 30\% de DME em 70\% de GLP (site da IDA, 2012).

Porém, devido à sua limitada produção no país, sua utilização resume-se apenas a propelente em aerossóis, em substituição às misturas butano-propano. 


\subsection{Reflexões sobre o capítulo 3}

Entre as inúmeras possibilidades da utilização de gases combustíveis para substituição da eletrotermia, em linhas gerais, os combustíveis que apresentam disponibilidade, capilaridade, flexibilidade e garantia de fornecimento são o gás natural, sob as modalidades canalizada, liquefeita ou comprimida, e o GLP que inclui a opção GNS. A utilização dos demais gases somente deverá ser considerada em situações excepcionais, devido às limitações quantitativas e geográficas na oferta e às suas características físico-químicas.

A intercambiabilidade entre os gases combustíveis de diferentes famílias, como o GLP e o GN, não é possível de ser feita sem nenhuma alteração dos queimadores convencionais. As condições de intercambiabilidade são determinadas pelas características dos gases, ou seja, o Índice de Wobbe e o Índice de Weaver e suas famílias (BIZZO et al., 2004). Porém existem queimadores duais, construídos para possibilitar esta intercambiabilidade através de geometrias internas variáveis e cavaletes de fluxo individualizados. Por motivos comerciais, a maioria dos queimadores duais foi desenvolvida para o uso do gás natural e do GLP devido à grande oferta destes energéticos no mercado mundial.

O GLP é a segunda opção para substituição da eletrotermia por gás combustível, na indisponibilidade de gás natural, apesar de sua rede de distribuição abranger uma área geográfica muito mais extensa que o gás natural, estando presente em todos os municípios do país. A maior vantagem do GLP é a mobilidade pois, se mantendo liquefeito sob pressões moderadas na temperatura ambiente, possibilita sua armazenagem e transporte em recipientes pressurizados relativamente leves.

O custo do gás natural para as indústrias é, de modo geral, inferior ao custo do GLP. Enquanto que as tarifas para o gás natural são tabeladas por suas distribuidoras e apresentadas em seus respectivos websites, onde os valores unitários cobrados são inversamente proporcionais ao consumo mensal, os preços do GLP obedecem à economia de mercado.

Os preços do gás natural para suas distribuidoras parte do valor cobrado na transferência de custódia nos citygates, enquanto que as distribuidoras de GLP tem por referência o preço exrefinaria. Os preços do gás natural não tem variado significativamente, considerando a soma commodity mais transporte, sendo no 9,24 US\$/MMBTU para o gás de origem nacional, 10,40 US\$/MMBTU para o gás de origem importada e 4,89 US\$/MMBTU para o gás aplicado em termelétricas, valores estes não ponderados, sem PIS/COFINS e sem ICMS (fonte http://www.investidorpetrobras.com.br, consulta em 27/07/2013). 
A unidade US\$MMBTU (dólar norte-americano por milhão de BTU) é calculada levando-se em conta o PCS do combustível, a saber:

- Gás natural: $9.400 \mathrm{kcal} / \mathrm{m}^{3} @ 20^{\circ} \mathrm{C}, 1 \mathrm{~atm}$ absoluta (www.comgas.com.br, consulta em 01.08.2013)

- GLP: $\quad 11.750 \mathrm{kcal} / \mathrm{kg} \quad$ (MME, 2013)

Considerando ainda que 1 MMBTU corresponde a $252.000 \mathrm{kcal}$, encontra-se:

- Gás natural: $1 \mathrm{MMBTU}=26,81 \mathrm{~m}^{3} \mathrm{GN} @ 20^{\circ} \mathrm{C}, 1 \mathrm{~atm}$ absoluta

- $\quad$ GLP: $\quad 1 \mathrm{MMBTU}=21,45 \mathrm{~kg}$ GLP

Os preços do GLP ex-refinaria variam de acordo com a origem (fonte de fornecimento) e a aplicação do gás. Os preços para as aplicações industriais variam de $\mathrm{R}$ \$1,2406 a R \$ 1,4649 por quilograma, sem agregar nenhum imposto, significando a faixa de 12,10 a 14,28 US\$MMBTU, considerada a taxa de câmbio de R\$2,20 / 1 US\$. Os impostos que incidem sobre o GLP são: PIS/COFINS, ICMS da refinaria e o ICMS da substituição tributária, atingindo um custo total para a distribuidora na faixa de $\mathrm{R} \$ 1,8354$ a $\mathrm{R} \$ 2,2896$ por quilograma, correspondente às variações de 17,90 a 22,32 US\$/MMBTU. A fonte de informação dos custos do GLP foi a Cia. Ultragaz S.A. em 01/08/2013. 


\section{ASPECTOS TECNOLÓGICOS NA TRANSFORMAÇÃO DE GASES COMBUSTÍVEIS EM CALOR}

Este capítulo tem por objetivo proporcionar o conhecimento básico necessário para a realização das conversões de eletrotermia para gases combustíveis, apresentando as alternativas disponíveis no atual estado-da-arte deste tema. Devido às características peculiares a cada situação, não poderia haver a intenção de que todos os casos estivessem solucionados no texto. O propósito do autor neste capítulo resume-se, então, em fornecer subsídios que levem à reflexão da complexidade do assunto e das alternativas possíveis ${ }^{6}$.

A conversão entre energéticos, de uma forma geral, tem por objetivo fornecer a mesma energia útil para os equipamentos, objetivando o atendimento à demanda térmica dos processos. Em muitos casos, considerando-se a argumentação apresentada anteriormente, é possível até estudar o fornecimento de um valor mais elevado para a potência útil, objetivando o aumento da produtividade do equipamento térmico após a conversão para gás combustível. Porém, nem sempre é possível fazer a conversão de eletricidade para gás, na medida em que o processo necessite de corrente elétrica além de calor, ou quando haja uma incompatibilidade técnica da chama ou dos produtos da combustão com o equipamento térmico ou com o processo, a qual não possa ser contornada por algum artifício.

A instalação de queimadores a gás em um equipamento originalmente projetado para eletrotermia exige um estudo prévio para determinar as características que sejam mais adequadas a cada processo. Inicialmente três opções devem ser estudadas quanto ao método de transferência de calor:

- Chama direta, onde os produtos da combustão entram em contato com a carga em processamento.

- Chama parcialmente confinada, onde os produtos da combustão entram em contato com a carga ou com a estrutura do equipamento térmico somente após sua temperatura ter se reduzido a um determinado valor limite, ocorrendo assim trocas de calor indireta e direta.

\footnotetext{
${ }^{6}$ Este capítulo foi redigido de acordo com a opinião e a experiência do autor, o que justifica as poucas referências bibliográficas citadas.
} 
- Chama indireta ou confinada, onde os produtos da combustão não entram em contato com a carga, ocorrendo a troca de calor através de superfícies estanques aos produtos da combustão como tubos radiantes ou muflas.

\subsection{Aplicações da chama direta}

Na opção onde os queimadores são instalados diretamente no mesmo ambiente da carga em processamento, ou seja, transferência de calor através da chama direta, onde os produtos da combustão têm contato com a carga, os processos de transferência de calor (radiação, convecção e condução) proporcionam um rendimento térmico mais elevado do que os métodos indiretos. Considerando-se os equipamentos térmicos que não tenham dispositivos para gerar uma convecção forçada, como ventiladores de recirculação e exaustores, comparando-se os rendimentos sob o aspecto da transferência de calor entre bancos de resistências elétricas e chamas diretas, enquanto as resistências proporcionam apenas a radiação e a convecção natural, os produtos da combustão com seus vetores-velocidade proporcionam convecção forçada além da convecção natural e da radiação. Sob este aspecto, a conversão da eletricidade para gás combustível tende a favorecer a opção gás com respeito à transmissão de calor.

Agregando a possibilidade do aumento da potência elétrica original do equipamento na conversão para gás, com uma transferência de calor mais intensa para a carga, torna-se atrativa a possibilidade do aumento da produtividade deste equipamento. Como exemplo, em uma indústria na cidade de Itu - SP haviam três fornos de queima de isoladores elétricos de porcelana, onde o aquecimento era feito por resistências elétricas no regime de operação intermitente. Após a conversão de apenas dois fornos elétricos para GLP, o aumento de produtividade obtido com o gás dispensou a conversão do terceiro forno, pois apenas dois equipamentos a gás proporcionavam a mesma produção diária obtida anteriormente. Este ganho ocorreu na etapa do aquecimento, pois os isoladores de porcelana suportavam um gradiente de temperaturas bem mais elevado do que as resistências elétricas poderiam proporcionar; e a conversão para GLP levou em conta este importante aspecto, dimensionando queimadores que liberavam uma potência útil significativamente maior em relação à potência elétrica útil original, reduzindo portanto o tempo desta etapa e culminando no aumento da produtividade. 


\subsection{Aplicações da chama parcialmente confinada}

Um caso particular da aplicação da chama direta é a chama parcialmente confinada. Esta opção deve ser aplicada quando não seja recomendável o contato físico dos produtos da combustão, em temperaturas elevadas, com a carga e/ou com a estrutura do equipamento térmico, pois poderia danificá-las. Assim, a chama e seus consequentes produtos da combustão deverão trafegar confinadamente até que sua temperatura se reduza e seja compatível com as estruturas nos arredores do ponto de liberação no interior do equipamento térmico. Esse confinamento parcial da chama e seus produtos pode ser obtido através superfícies cerâmicas ou metálicas, sob a forma de tubos ou muflas. Durante esta etapa da queima, a transferência de calor dos produtos da combustão se processa de forma indireta para a carga, através das citadas superfícies de troca térmica. A partir do momento quando a temperatura dos produtos da combustão tenha diminuído o suficiente para que possa ser suportada pela estrutura do equipamento ou por sua carga, esses gases quentes passam a trafegar livremente no interior do equipamento, trocando calor diretamente em contato com a carga.

\subsection{Aplicações da chama indireta ou confinada}

E, finalmente, existem os casos de conversão de equipamentos eletrotérmicos para gás combustível, onde os produtos da combustão não podem entrar em contato com o ambiente onde se situa a carga a aquecer. Os motivos para esta incompatibilidade podem ser a necessidade de atmosferas controladas (neutras, carburantes, redutoras, amoniacais ou com baixo ponto de orvalho), como nos processos de tratamento térmico, onde a introdução de produtos da combustão é quimicamente incompatível com as referidas atmosferas.

Além disso, a presença de chama como fonte de ignição é indesejável quando existam riscos envolvidos devido à presença de compostos inflamáveis na atmosfera controlada, como hidrogênio, propano, vapores de solventes orgânicos e alguns tipos de sólidos finamente divididos como pó.

Em todos estes casos, torna-se obrigatória a utilização de chama confinada. Este confinamento da chama pode ser realizados através de dois artifícios: 
I. Confinando a chama e o trajeto dos produtos da combustão no interior de tubos radiantes, sendo o calor transferido através de tais tubos para o ambiente onde se situa a carga.

II. Ou, então, com a utilização de muflas metálicas ou cerâmicas que confinam o ambiente da carga em seu interior, havendo estanqueidade entre os produtos da combustão e o compartimento destinado à carga, de forma a manter a atmosfera controlada no interior das muflas, sem contaminação e riscos, em todos os casos.

\subsection{Tipos de queimadores a gás}

$\mathrm{Na}$ conversão de equipamentos eletrotérmicos para gás combustível é de primordial importância a escolha dos queimadores e tipo de chama mais adequados ao equipamento térmico, além do seu correto posicionamento. No mercado brasileiro existe ampla disponibilidade de queimadores a gás, tanto de origem nacional como importados, possibilitando a seleção do tipo e do modelo mais adequado para cada situação. Como toda a seleção de equipamento, existe sempre o conflito entre o relacionamento custo-benefício, onde geralmente o menor custo implica em, também, menor benefício. Por outro lado, queimadores mais sofisticados e com componentes de maior qualidade exigem maiores investimentos mas proporcionam uma combustão mais eficiente, praticando-se baixos índices de excesso de ar de combustão, acarretando em economia de gás, menores índices de emissões, reduzidos custos de manutenção e menor número de paradas para correção de falhas, colaborando assim para uma maior produtividade.

\subsubsection{Classificação dos queimadores}

Os queimadores a gases combustíveis podem ser classificados sob diferentes aspectos:

- Quanto ao gás combustível utilizado: queimadores convencionais, que utilizam apenas gases da mesma família, como gás manufaturado reformado ( $1^{\text {a }}$ família), gás natural e ar-propanado ( $2^{\mathrm{a}}$ família) ou como GLP ( $3^{\mathrm{a}}$ família); e queimadores duais, que utilizam combustíveis de duas diferentes famílias, geralmente gás natural e GLP.

- Quanto ao fornecimento de comburente utilizado: queimadores ar-gás; queimadores oxigênio-gás; e queimadores ar-oxigênio-gás. 
- Quanto ao fornecimento do ar de combustão: queimadores a ar aspirado, admitido por pressão negativa gerada pelo fluxo de gás combustível e/ou ventilador de exaustão; queimadores a ar insuflado geralmente por ventiladores centrífugos, também conhecidos como ventoinhas; e sistema misto ou balanceado, onde o ar é insuflado nos queimadores e os produtos da combustão são exauridos através de ventilador de exaustão - geralmente utilizado quando existem perdas de carga significativas a serem vencidas no trajeto desde os queimadores até a liberação dos gases na atmosfera.

- Quanto ao tipo de mistura do gás combustível com o comburente: queimadores de prémistura, onde o gás e o comburente são previamente misturados e conduzidos para o bocal de queima; e queimadores de mistura na face, onde o gás e o comburente são misturados no bocal de queima.

- Quanto ao material bocal de queima: queimadores dotados de bocais cerâmicos e queimadores com bocais metálicos.

- Quanto à velocidade de saída no bocal de queima: queimadores de baixa, média e alta velocidades.

- Quanto ao auto-preaquecimento do ar de combustão: queimadores recuperativos, abertos em câmaras pressurizadas, e fechados em tubos radiantes; queimadores regenerativos dotados de câmaras de regeneração.

- Quanto à característica peculiar de transmissão de calor, se encontram: queimadores infravermelhos, onde o gás superaquece uma superfície metálica ou cerâmica, a qual emite uma parcela significativa de calor nas frequências e nos comprimentos de onda do espectro infravermelho; e queimadores de duto, que aquecem convectivamente um fluxo de ar no interior de um duto, podendo o ar de combustão ser fornecido pelo próprio duto ou por ventilador externo.

- Quanto ao sistema de refrigeração: queimadores auto-refrigerados, ou seja, arrefecidos pelo fluxo do comburente (ar e/ou oxigênio), pelo fluxo do gás e pelo craqueamento das moléculas do gás; e queimadores refrigerados a água, dotados de uma camisa geralmente externa, onde existe uma circulação contínua de água para evitar o superaquecimento do bocal de queima e/ou, no caso de queimador de pré-mistura gáscomburente, a detonação no interior corpo do queimador.

- Quanto à configuração dos blocos do queimador: queimadores tipo monobloco, nos quais o bocal de queima e o ventilador estão agrupados em um único bloco ou conjunto, onde geralmente o cavalete das válvulas de controle e o módulo de comando 
também estão incorporados; e queimadores tipo duobloco, onde o bocal de queima, o ventilador, o cavalete e o módulo de comando estão separados, como mais detalhadamente explicado a seguir.

\subsubsection{Adequação dos queimadores às temperaturas de processo}

Esta adequação dos tipos de queimadores é a primeira consideração a ser feita quando se inicia um estudo para conversão de eletrotermia para gás combustível.

\subsubsection{Queimadores monobloco}

Os queimadores monobloco, como o próprio nome indica, são constituídos por um único conjunto de peças englobando o ventilador e dispositivo de controle de vazão do ar de combustão, o cavalete de alimentação e controle de gás, o piloto e o sistema de controle e segurança de chama. O citado cavalete, também conhecido como rampa de gás, é constituído por uma válvula de bloqueio rápido manual, filtro, dispositivo de regulagem da pressão (preferivelmente com bloqueio automático por pressão inadequada), pressostatos de alta e baixa pressão de gás, sistema de bloqueio e controle da vazão de gás e alimentação do piloto. A aplicação desses queimadores se restringe a processos de baixas temperaturas, devido à proximidade dos seus componentes elétricos e eletrônicos com o equipamento térmico, devido principalmente à ação danosa do calor proveniente da câmara de combustão sobre as partes internas e externas do queimador, além do cavalete de gás.

Não existe uma definição rígida com respeito às classes de temperaturas de processos industriais. Trinks (1961) se refere aos processos de baixa temperatura através da terminologia na língua inglesa oven, geralmente aplicável aos fornos que operam até $1.000^{\circ} \mathrm{F}$ ou $538^{\circ} \mathrm{C}$, os quais não emitem radiação na faixa da luz visível, embora haja a exceção dos fornos de coqueria (coke oven) que operam por volta de $1.200^{\circ} \mathrm{C}$. Já Her Majesty’s Stationery Office (1969) define os processos de baixa temperatura aqueles inferiores a $750^{\circ} \mathrm{C}$, partindose da predominância da transferência de calor convectiva nessas temperaturas.

A norma brasileira da ABNT NBR 12313 (ABNT, 2000) estabelece um divisor de água entre processos de baixa e alta temperatura, mas a aplicação deste conceito está direcionada exclusivamente à definição das exigências para os sistemas de controle e segurança deste 
documento, no que tange às condições de partida, operação e parada dos queimadores a gás. Esta norma considera:

- processos de baixa temperatura, cuja temperatura nas superfícies internas da câmara de trabalho seja igual ou abaixo de $750^{\circ} \mathrm{C}$, não podendo ser considerada suficiente para promover a autoignição do gás e exigindo assim dispositivos mais sofisticados para supervisão de chama e sequenciamento de partida;

- e processos de alta temperatura, onde a temperatura nas referidas superfícies esteja acima de $750^{\circ} \mathrm{C}$, sendo suficiente para garantir a autoignição do gás.

Observando-se as temperaturas mínimas de autoignição, ou ignição expontânea, dos principais gases combustíveis em suas misturas nas proporções estequiométricas com ar na Tabela 8, conclui-se que o limite estabelecido pela norma NBR 12313 admite um fator de segurança, visto que a mais elevada temperatura mínima é de $650^{\circ} \mathrm{C}$ correspondente ao monóxido de carbono, portanto ainda $100^{\circ} \mathrm{C}$ abaixo do valor estabelecido pela norma.

Tabela 8 - Temperaturas mínimas de autoignição

\begin{tabular}{lcc}
\hline \multicolumn{3}{c}{ TEMPERATURAS MÍNIMAS DE AUTOIGNIÇÃO $\left({ }^{\circ} \mathrm{C}\right)$} \\
GÁS COMBUSTÍVEL & $\begin{array}{c}\text { FONTES DE REFERÊNCIA } \\
(1)\end{array}$ & $(2)$ \\
\hline Metano & 537 & $537-595$ \\
Etano & - & $472-515$ \\
Eteno & 490 & $425-490$ \\
Propano & 493 & $470-493$ \\
Propeno & 455 & 455 \\
N-Butano & 287 & $365-430$ \\
Iso-Buteno & - & $385-440$ \\
Monóxido de carbono & 650 & 609 \\
Hidrogênio & 572 & 400 \\
\hline Condições: & \multicolumn{3}{l}{} \\
• pressão atmosférica de $101,3 \mathrm{kPa}$ \\
. misturas estequiométricas de gás com ar \\
\hline \multicolumn{4}{l}{} \\
\hline
\end{tabular}

Fonte: elaboração própria

(1) Ahlberg (1985); (2) Bartok (1991) 
De acordo com Bartok (1991), as variações encontradas na determinação das temperaturas mínimas de autoignição são extremamente dependentes das condições do ensaio experimental, razão pela qual apresentam variações de acordo com a literatura.

Portanto, a classificação preconizada pela norma NBR 12313 tem seu objetivo nobre e específico quanto à segurança dos sistemas de controle e segurança dos queimadores, não objetivando a classificação das temperaturas dos processos térmicos industriais, sendo válidas as classificações dos processos de baixa, média e alta temperatura, ainda que não existam limites exatamente definidos.

Assim, os queimadores monoblocos são habitualmente instalados em processos de baixa temperatura como caldeiras a vapor, aquecedores de água, aquecedores de óleos térmicos, geradores e estufas de ar quente para uma infinidade de processos de secagem e cura, além de fornos de cadinho para metais de baixo ponto de fusão, fornos de tratamento térmico e decoração de vidro, aquecimento de banhos de limpeza para galvanoplastia, fornos para indústria alimentícia e muitos outros.

A Figura 18 mostra um queimador monobloco instalado em um aquecedor de fluido térmico.

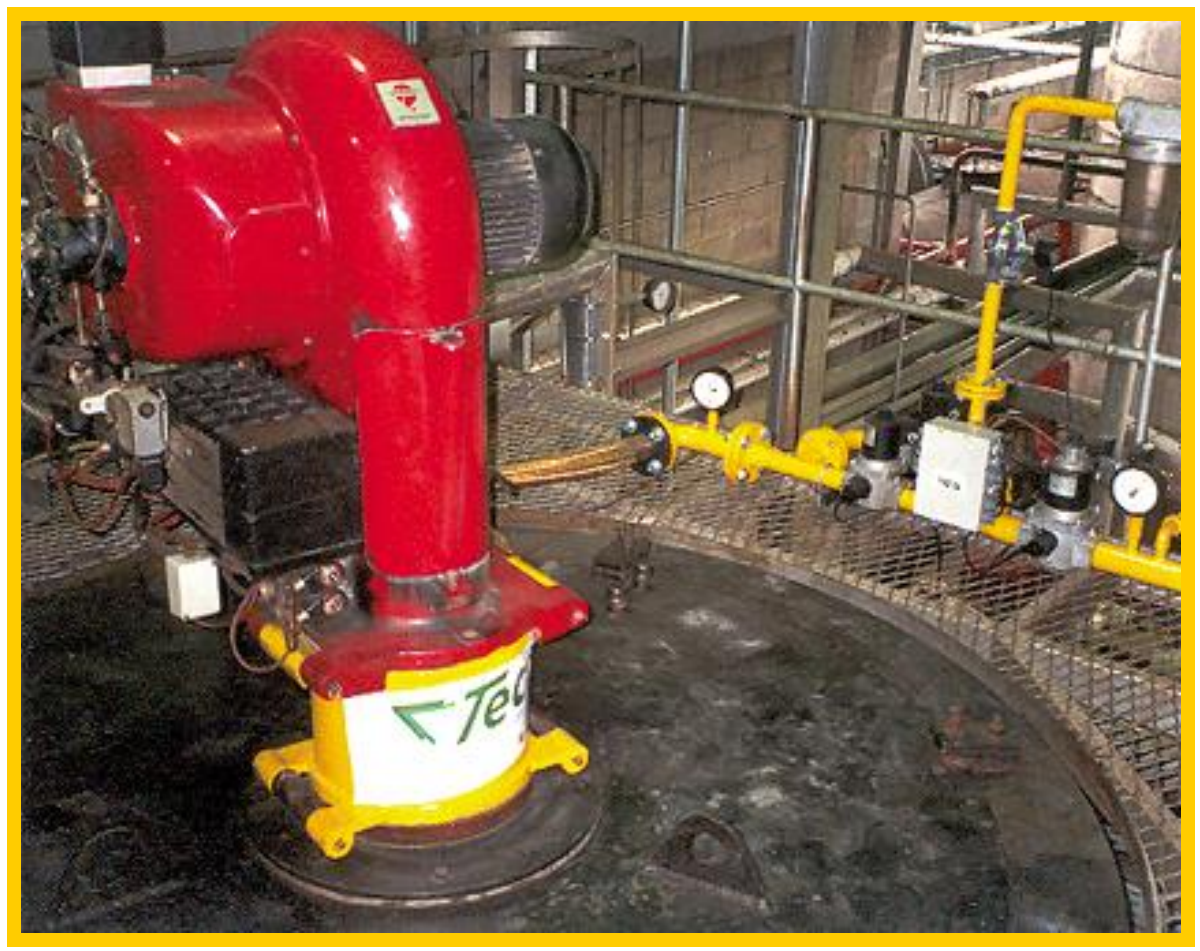

Figura 18 - Queimador monobloco a gás

Fonte: foto cedida por cortesia da TEC Tecnologia em Calor Ltda. 
Além do superaquecimento de componentes sensíveis ao calor, o que contraindica a aplicação dos queimadores tipo monobloco em processos de média e alta temperatura, existem ainda outros fatores como a agressividade do meio ambiente nas proximidades destes queimadores como presença excessiva de pós e fumos, atmosferas corrosivas, queda de sucata e respingos de metais e de escória.

\subsubsection{Queimadores duobloco}

Os queimadores duobloco apresentam-se, como a denominação indica, com seus componentes em dois conjuntos separados. A Figura 19 mostra um queimador duobloco em operação. Assim as partes mais sensíveis ao calor, como ventilador do ar de combustão com motor elétrico, componentes eletrônicos, pressostatos, válvulas de controle e bloqueio (destacadas na Figura 19 pela elipse maior), podem ser posicionadas de forma evitar a agressões dos processos de média e alta temperatura, condições essas inadequadas aos queimadores monoblocos. E apenas as partes mais robustas do queimador, constituída pelo cabeçote de queima, piloto e bloco refratário (Figura 19, destaque menor), ficam expostas às agressividades já anteriormente citadas, além do calor radiativo, convectivo e condutivo.

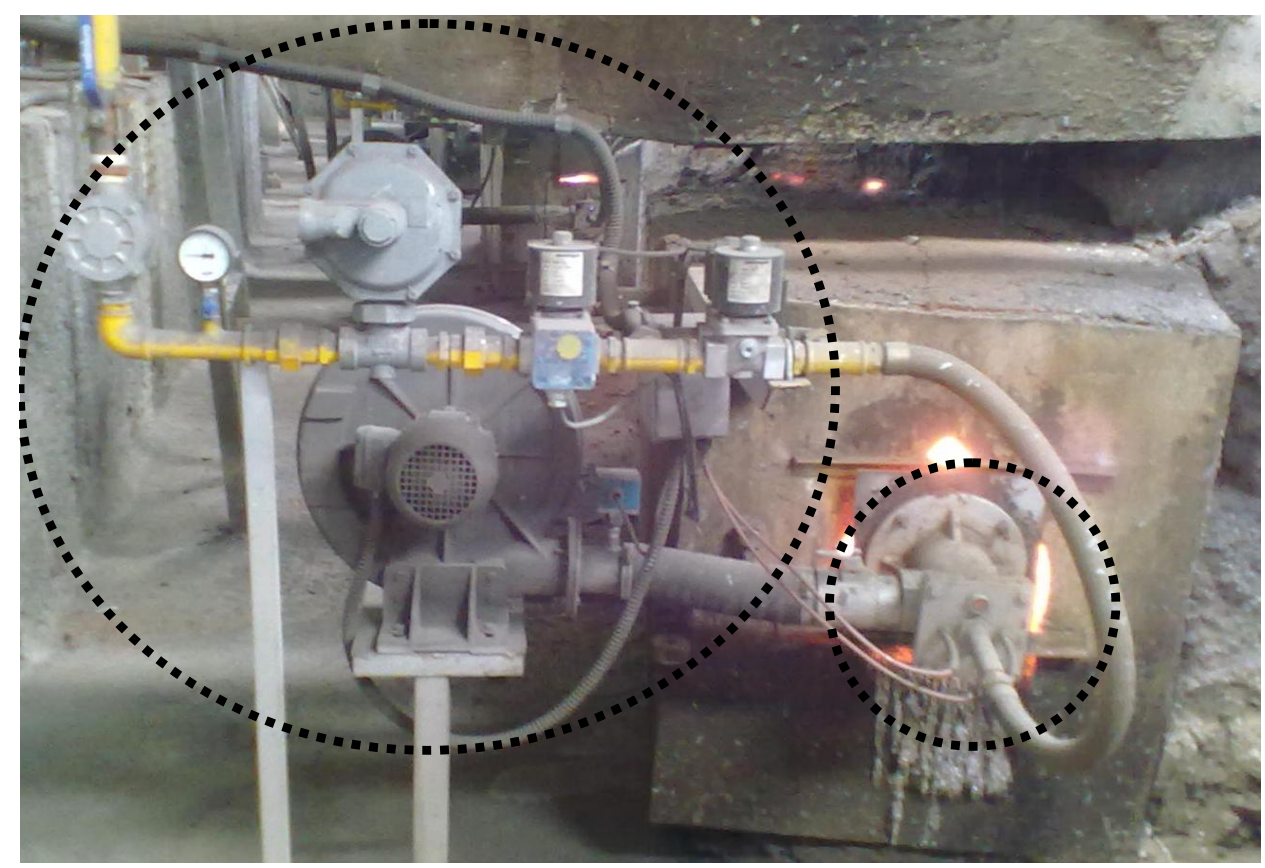

Figura 19 - Queimador duobloco a gás

Fonte: foto do acervo do autor 
Em alguns casos, a proteção dos componentes mais sensíveis pode ser realizada com o distanciamento dos fatores agressivos ou com a colocação de barreiras de proteção, o que só é possível fazer com queimadores duobloco.

Embora não haja uma definição rígida, estes queimadores devem ser instalados em processos de média e alta temperaturas. Os processos de média temperatura abrangem quase a totalidade dos fornos de fusão de metais não ferrosos, fornos de esmaltação e fornos de tratamento térmico de metais ferrosos e não ferrosos, numa faixa de temperaturas da ordem de $650^{\circ}$ a $1.000^{\circ} \mathrm{C}$. E, por sua vez, os processos de alta temperatura podem ser considerados aqueles que atingem temperaturas acima de $1.000^{\circ} \mathrm{C}$, como fornos de fusão de metais ferrosos e vidros, fornos cerâmicos (refratários, revestimentos, isolantes, louça de mesa e sanitária) e fornos de reaquecimento para laminação e forjaria.

Algumas vezes, queimadores duoblocos são instalados em processos de baixas temperaturas, principalmente em equipamentos térmicos com múltiplos queimadores, por apresentarem menor custo em relação aos monoblocos nesta situação, por permitir a instalação de apenas um cavalete comum a todos os queimadores e um único ventilador do ar de combustão.

\subsubsection{Queimadores de duto}

A chama dos queimadores de duto se estabelece no interior de uma estrutura prismática, onde o gás é liberado em espalhador tipo flauta, com o propósito de queimar em ambiente protegido do fluxo principal, aquecendo diretamente o ar ou a mistura gasosa que flui através desse duto. $\mathrm{O}$ ar de combustão pode ser fornecido pelo fluxo do próprio duto, quando tenha condições de atender às necessidades como comburente (velocidade mínima para garantir a vazão e teor de oxigênio adequado), através de múltiplas aberturas na estrutura prismática, ou fornecido por ventilador externo através de um plenum de insuflamento. Em ambos os casos, praticamente todo o calor liberado pela chama é absorvido pelo fluxo do duto, apresentando uma elevada eficiência de aquecimento, comparável com o aquecimento similar realizado por resistências elétricas. A Figura 20 mostra esquematicamente os dois tipos de queimadores de duto: no lado esquerdo, o queimador onde o ar de combustão aproveita o fluxo do próprio duto através de orifícios calibrados; e o queimador do lado direito dotado de plenum de insuflamento de ar alimentado externamente por ventilador, onde o fluxo de ar de combustão provem do ambiente externo. 


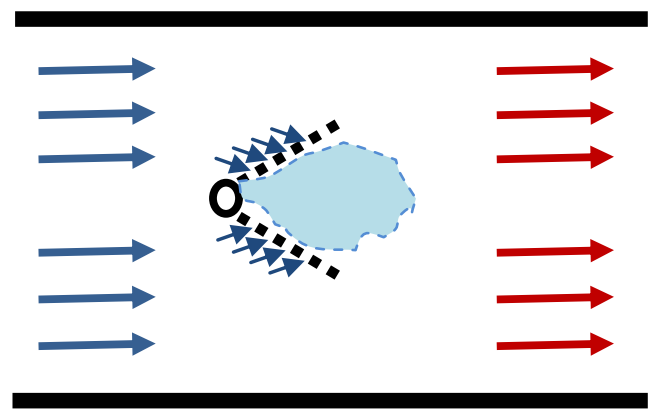

Ar de combustão fornecido pelo duto

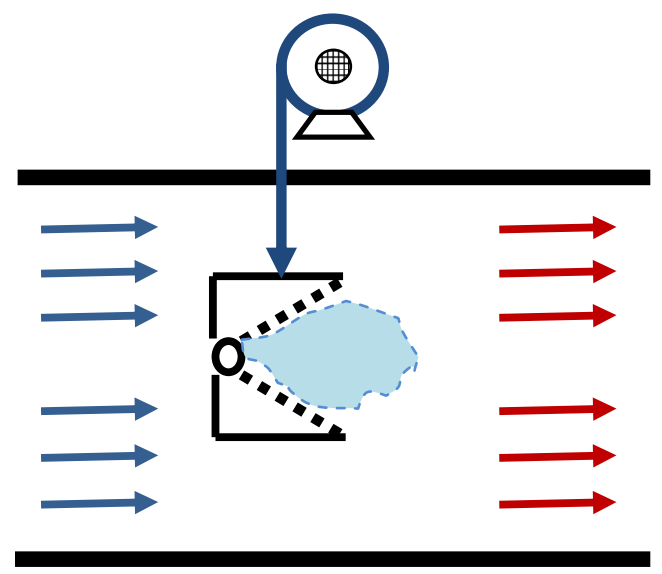

Fornecimento externo do ar de combustão

Figura 20 - Instalações de queimadores de duto

Fonte: elaboração própria

Os queimadores de duto, sendo modulares, possibilitam a montagem com múltiplos módulos acoplados nas mais diversas configurações, para atender à potência desejada e com a geometria mais indicada para se adaptar ao duto de ar quente (Figura 21).

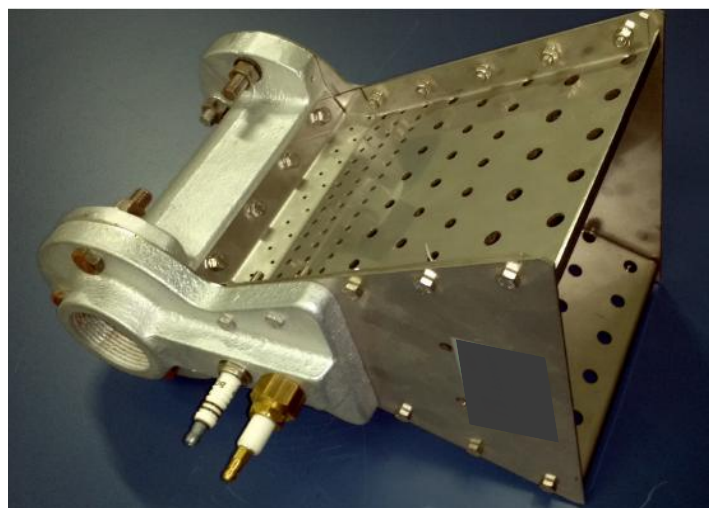

Módulo independente

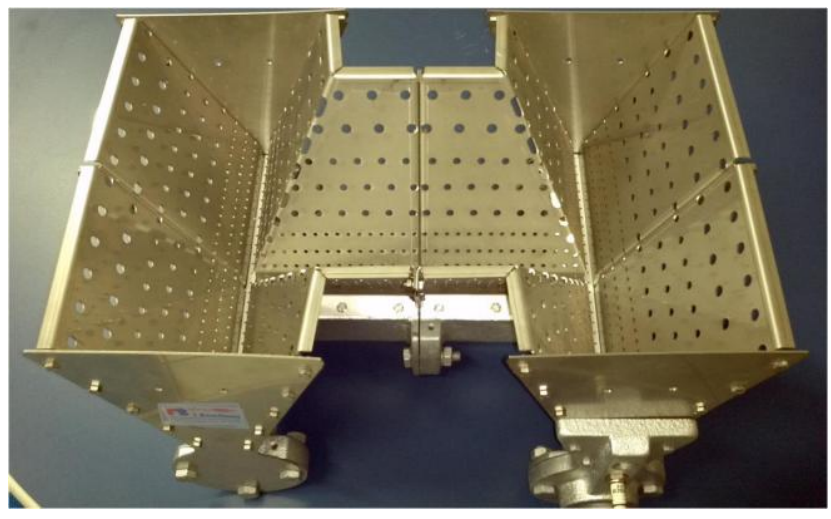

Módulos múltiplos acoplados

Figura 21 - Queimadores de duto

Fonte: foto cedida por cortesia da PRB Combustão Industrial Ltda.

\subsubsection{Queimadores infravermelhos}

Outra alternativa para a substituição da eletrotermia são os queimadores a gás do tipo infravermelhos. Assim como bancos de resistência, os queimadores infravermelhos 
transferem uma importante parcela de calor por radiação. Este sistema de transferência de calor é muito adequado para aquecimento superficial, onde os painéis infravermelhos se posicionam paralelamente às superfícies a serem aquecidas. Alguns queimadores possibilitam ainda duas configurações de chama, conforme mostra comparativamente a Figura 22, proporcionando parcelas de transferência de calor mais intensas por radiação (painel incandescente) ou por convecção (chama azul), esta última obtida elevando-se o excesso de ar de combustão.

Como exemplo de aplicação de transferência de calor para superfícies, cabe citar as máquinas rotativas que produzem papel para embalagem e secadores para fixação de produtos em tecidos como entretelas e engomagem.

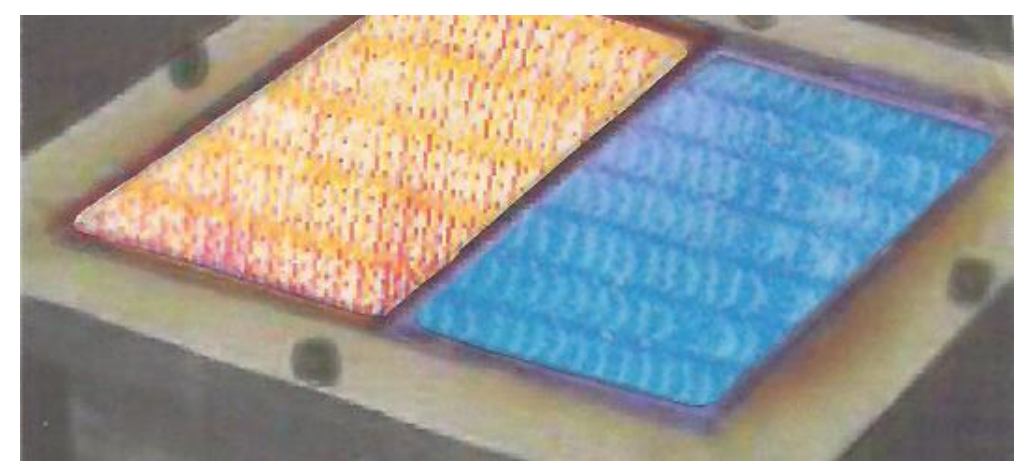

Figura 22 - Queimador infravermelho

Fonte: Foto cedida por cortesia da PRB Combustão Industrial Ltda.

\subsubsection{Queimadores oxigênio-gás}

E, finalmente, os queimadores oxigênio-gás, onde as principais características da queima são as altas velocidades de chama e o baixo volume específico dos produtos da combustão, além das elevadas temperaturas de chama, quando se utiliza oxigênio puro oriundo de plantas criogênicas ASU - Air Separation Unit (acima de 99,99\% em volume) ou oxigênio produzido por concentradores através dos processos PSA - Process Swing Adsortion e VPSA - Vacuum Pressure Swing Adsorption, geralmente obtendo teores do comburente na faixa de 92 a $95 \%$ $(\mathrm{v} / \mathrm{v})$.

A Tabela 9 indica as temperaturas adiabáticas de chama obtidas na queima do metano e do propano com ar e com oxigênio puro, para queima nas proporções estequiométricas, na pressão atmosférica e considerando a temperatura inicial do combustível e do comburente a $25^{\circ} \mathrm{C}$ 
Tabela 9 - Temperaturas adiabáticas de chama

\begin{tabular}{ccc}
\hline \multirow{2}{*}{ GÁS } & $\begin{array}{c}\text { TEMPERATURAS ADIABÁTICAS } \\
\text { DE CHAMA }\left({ }^{\circ} \mathrm{C}\right)\end{array}$ \\
& gás com ar & gás com oxigênio \\
\hline metano & 1.937 & 2.757 \\
propano & 1.994 & 2.821 \\
\hline
\end{tabular}

Condições para combustíveis e comburentes:

- pressão atmosférica

. misturas em proporções estequiométricas

. temperatura de partida: $25^{\circ} \mathrm{C}$

Fonte: elaboração própria a partir de Glassman (1996, p.26, 27 e 28)

Para fins de natureza prática, pode-se assumir as temperaturas adiabáticas de chama do metano como sendo do gás natural, e a do propano como sendo do GLP. Porém, como não existe equipamento térmico adiabático, as temperaturas de chama efetivas variam, sendo significativamente inferiores a estes valores, os quais servem apenas como referência.

Este tipo de chama oxi-combustível, pelas citadas características, torna-se adequada à conversão de processos de eletrotermia de alta temperatura para gás combustível, considerando que os equipamentos elétricos não tenham sido projetados originalmente para comportar o tráfego de produtos da combustão no caso da conversão parcial. A Tabela 10 mostra a significativa redução dos volumes específicos dos produtos da combustão quando se substitui o ar por oxigênio.

Tabela 10 - Volumes específicos de produtos da combustão

\begin{tabular}{lcc}
\hline \multirow{2}{*}{ COMBUSTÍVEL } & $\begin{array}{c}\text { PRODUTOS DA COMBUSTÃO ESTEQUIOMÉTRICA } \\
\text { COM AR }(*)\end{array}$ & COM OXIGÊNIO $(* *)$ \\
\hline Gás natural $(* * *)$ & $367,8 \mathrm{~kg} / \mathrm{MMBTU}$ & $100,5 \mathrm{~kg} / \mathrm{MMBTU}$ \\
GLP $(* * * *)$ & $356,0 \mathrm{~kg} / \mathrm{MMBTU}$ & $98,1 \mathrm{~kg} / \mathrm{MMBTU}$ \\
\hline
\end{tabular}

Observações:

(*) calculado a partir dos dados do programa Vulcano 1.1

(**) considerando composição mássica do $\operatorname{ar}=23 \% \mathrm{O}_{2}+77 \% \mathrm{~N}_{2}$

(***) composição típica do gás natural da Bolívia

(****) composição média típica segundo programa Vulcano 1.1

Fonte: elaboração própria 
Os queimadores a oxigênio, operando com gases combustíveis, podem ser do tipo bloco cerâmico como o da Figura 23, dispensando sistema de refrigeração, ou ser do tipo metálicos (preferencialmente fabricados em aços austeníticos) refrigerados a água através de dupla camisa externa, com circuito fechado de circulação e fonte fria para arrefecimento, geralmente torre atmosférica de resfriamento ou fluido de processo. A oxi-combustão possibilita também o uso de gases combustíveis de baixo poder calorífico, de forma a elevar sua temperatura de chama a ponto de torná-los compatíveis com a temperatura do processo. Por exemplo, um gás de alto forno de $811 \mathrm{kcal} / \mathrm{Nm}^{3}$ queimando com oxigênio puro apresenta uma temperatura de chama equivalente a um gás de $2.900 \mathrm{kcal} / \mathrm{Nm}^{3}$ queimando com ar, possibilitando sua aplicação em processos de média temperatura (COSTA, 1984), podendo substituir a eletrotermia em fornos de alívio de tensões para produtos forjados, por exemplo, no âmbito de uma siderúrgica integrada ou sua vizinhança.

Existem ainda queimadores oxi-gás metálicos refrigerados pelo próprio fluxo do oxigênio de combustão em altas velocidades, mas sua aplicação é restrita devido ao seu baixo turndown ratio para não prejudicar a condição de refrigeração quando operando em baixa potência, conforme comprovou o autor nas experiências que acompanhou no Laboratório de Combustão da AGA Aktiebolag, em Lidingö - Suécia em 1988. Sendo tecnicamente viável a instalação de queimadores refrigerados a oxigênio, existe um pequeno ganho de conservação de energia, pois o calor que seria arrefecido pelo fluxo de água retorna ao processo térmico como entalpia do oxigênio preaquecido.

A foto do lado esquerdo da Figura 23 mostra um queimador oxigênio-gás natural instalado em um forno revérbero para fusão de alumínio, na empresa Alumínio Reynolds na cidade de Barranquilla na Colômbia, aplicação esta desenvolvida pelo autor na década dos anos 90. A figura do lado direito mostra o mesmo queimador visto operando no interior do citado forno, com sua chama azulada, de alta velocidade e muito firme.

O que não pode ser esquecido na conversão de eletrotermia para gás combustível, quando se utiliza queimadores a oxigênio, é que a produção deste comburente tem como principal insumo energético a energia elétrica. Portanto economiza-se com a substituição da eletrotermia, mas consome-se energia elétrica para produção do oxigênio. O Apêndice A apresenta os diversos consumos específicos de energia elétrica em função do tipo da planta que produz o oxigênio, do estado físico (gasoso ou líquido criogênico), da pressão praticada e do grau de pureza obtido. 

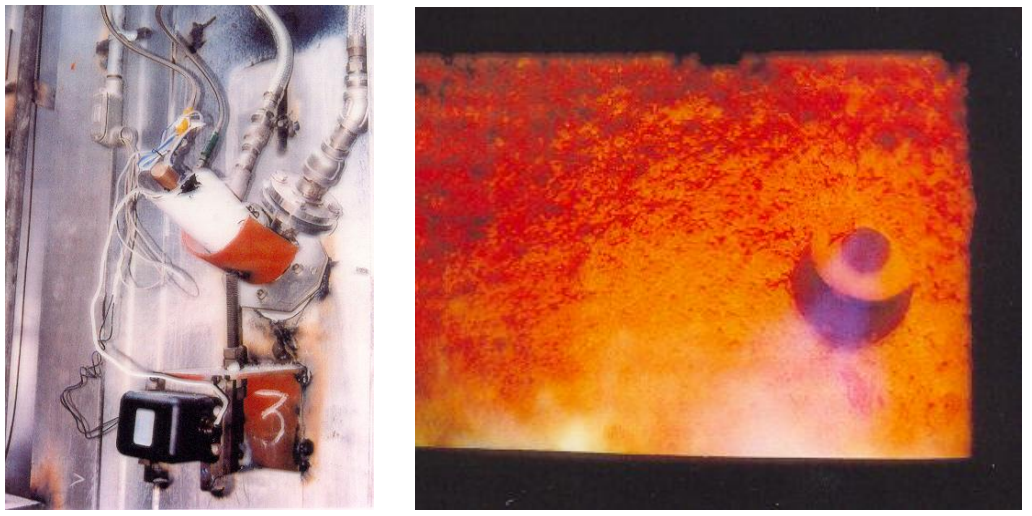

FIGURA 23 - Queimador oxigênio-gás natural

Fonte: fotos do acervo do autor, em forno revérbero de alumínio

\subsubsection{Modalidades operacionais dos queimadores}

Outra característica importante, a ser especificada na conversão de eletrotermia para gás combustível, é a modalidade da liberação da potência na câmara de combustão, que poderá ser realizada:

- em apenas um estágio;

- em dois estágios;

- de forma modulante.

\subsubsection{Queimadores de único estágio}

Os queimadores de único estágio, sejam do tipo monobloco como duobloco, se caracterizam por operar apenas em uma única potência, determinada por regulagem na instalação do queimador. Assim o queimador pode apenas estar ligado, fornecendo determinada potência, ou desligado. Estes queimadores só são fabricados para baixas potências, raramente superando $600 \mathrm{~kW}$. Apesar dessa restrição operacional, este tipo de queimador possui mercado em virtude do seu baixo custo e é aplicável em processos que não exijam um controle de temperatura muito apurado. Os queimadores de um estágio costumam acarretar em um consumo específico mais elevado nos processos onde são aplicados pois, a cada reacendimento, sempre deve ser feita a pré-purga da câmara de combustão e seus periféricos com o insuflamento do ar de combustão, de acordo com as muitas exigências e raras exceções estabelecidas pela norma NBR 12313:2000 (ABNT, 2000). As citadas pré-purgas com ar 
roubam sempre algum calor do processo, portanto quanto mais intermitentemente opere o queimador e maior a temperatura do processo, mais calor será perdido.

\subsubsection{Queimadores de dois estágios}

Os queimadores de dois estágios atingem até médias potências, na faixa de 1 a $2 \mathrm{MW}$ e, quando ligados, podem proporcionar duas potências distintas conhecidas como chama baixa e chama alta. Tais potências também são possíveis de serem determinadas para cada caso, dentro da relação entre as potências máxima e mínima do queimador ${ }^{7}$. A escolha ideal para estabelecer as potências para as chamas alta e baixa de um queimador de duplo estágio seria aquela onde, na maior parte do tempo operacional do equipamento térmico, o queimador permanecesse modulando entre as chamas alta e baixa sem desligar. Outra característica muito importante dos queimadores de dois estágios é o suprimento do ar de combustão, o qual também deve ser fornecido em duas vazões, uma para chama alta e outra para chama baixa, de forma a minimizar o excesso de ar de combustão em ambas as potências. Porém existem queimadores de dois estágios de menor custo que fornecem apenas uma única vazão de ar de combustão, dimensionada para a alimentação do comburente quando operando em chama alta; assim, quando em chama baixa, existe um elevado excesso de ar de combustão acarretando em consumo desnecessário de gás combustível.

\subsubsection{Queimadores modulantes}

E, por último, os queimadores modulantes são fabricados para operar em todas as faixas de potência. Como a própria denominação indica, sua principal característica é a modulação da potência de uma forma contínua, mantendo a proporcionalidade das vazões de gás combustível e ar de combustão entre suas potências máxima e mínima. Esta proporção gásar pode ser obtida através de dispositivos mecânicos, pneumáticos ou eletrônicos, os quais atuam direta ou indiretamente sobre as válvulas que controlam as vazões do gás combustível e do comburente. Porém a qualidade da combustão depende também das proporções gás-ar, as quais variam de acordo com o tipo de dispositivo e sua concepção, a saber:

\footnotetext{
${ }^{7}$ Esta relação é conhecida no Brasil pelo jargão do idioma inglês turndown ratio; por exemplo, o turndown ratio de 5:1 significa que o queimador pode operar entre as potências de 20\% a 100\% de sua potência máxima.
} 
- Dispositivos mecânicos: são os mais baratos, mas apresentam menos recursos para se obter uma proporção gás-ar mais próxima da ideal em toda a faixa de potências, através de hastes articuladas, ou ainda utilizando-se de pistas excêntricas (cames).

- Dispositivos pneumáticos: utilizam um sinal de pressão do próprio ar de combustão, proporcional à sua vazão, que atua direta ou indiretamente na válvula que controla a vazão do gás; estes dispositivos geralmente apresentam uma maior qualidade de desempenho quando comparados com os sistemas mecânicos.

- Dispositivos eletrônicos: costumam apresentar uma ótima qualidade no controle das proporções gás-ar, cuja principal característica é a independência mecânica ou pneumática das válvulas de controle de ar e gás; assim, a qualidade da combustão dependerá ainda da precisão das válvulas e seus tempos de resposta, enquanto a eficiência do processo neste particular dependerá da programação, principalmente da sintonia do controlador de potência com a demanda térmica do processo.

\subsubsection{Configurações de chama}

Uma das grandes vantagens da utilização de combustíveis gasosos na conversão de fornos eletrotérmicos é o fato de a chama ser menos radiante que a dos combustíveis líquidos, não concentrando excessivamente a liberação de calor por radiação nos locais onde os queimadores estão instalados. Como as resistências elétricas possuem baixa concentração de calor, comparativamente com queimadores, torna-se necessária sua distribuição em áreas significativamente grandes no interior do equipamento térmico, como paredes, teto e piso, favorecendo uma transmissão de calor mais uniforme. Por outro lado, a transmissão de calor a partir das resistências elétricas acarreta, além da radiação, apenas a convecção natural caso não haja dispositivo instalado para recirculação forçada no interior do equipamento.

Os gases combustíveis, por sua vez, apresentam a possibilidade da conformação da chama nos mais variados formatos, adequando-a às necessidades do equipamento térmico. Essas características em muito facilitam a adaptação de queimadores nos equipamentos eletrotérmicos onde, certamente, o projeto original não contemplou a utilização de combustíveis. Portanto, além da escolha do tipo de queimador e do seu controle de potência, é de grande importância a determinação do formato da chama em função da localização dos queimadores e do posicionamento da tiragem na conversão dos equipamentos para gás. 
Os tipos mais comuns de formatos de chamas e suas respectivas descrições estão disponíveis no Apêndice B.

\subsection{Reflexões sobre o capítulo 4}

Neste capítulo foram apresentadas as inúmeras alternativas para a transformação de gases combustíveis em calor, com o objetivo de proporcionar o conhecimento básico de todas as opções possíveis de serem consideradas na substituição da eletrotermia, em virtude da escassez de informações adequadamente agrupadas neste assunto.

Assim, mesmo que o leitor não tenha conhecimentos técnicos suficientes para a especificar o sistema de queima adequado a cada caso, ele poderá fazer objeções e sugerir configurações para o profissional ou para a empresa que irá realizar este trabalho. 


\section{ALTERNATIVAS PARA A SUBSTITUIÇÃO DA ELETROTERMIA NO AQUECIMENTO DIRETO}

O objetivo deste capítulo é apresentar as alternativas para substituir a eletrotermia por gases combustíveis no aquecimento direto, estimar os potenciais tecnológicos para cada setor industrial, consolidar os resultados e estimar a projeção destes potenciais para o ano de 2012 . As alternativas para a substituição da eletrotermia, tanto no aquecimento direto (AD) como no calor de processo $(\mathrm{CP})$, tomaram por base as informações quantitativas informadas pelo último Balanço de Energia Útil - BEU publicado no ano de 2005 (MME, 2005), com base no ano 2004. Portanto esta pesquisa está limitada à qualidade dos dados informados pelo BEU. A partir destas informações, foram estimados os coeficientes de substituição da eletrotermia, como percentagem do consumo de energia final de cada setor analisado. Tais estimativas basearam-se em literatura específica, trabalhos acadêmicos, informações de profissionais da área e em previsões baseadas na experiência e pesquisas do autor. $\mathrm{O}$ algoritmo utilizado na determinação está indicado no diagrama de blocos da Figura 24. Os blocos na cor azul correspondem à energia elétrica, iniciando-se com o valor da energia final para cada setor, sobre o qual é aplicado o coeficiente de substituição encontrando-se o potencial de substituição, e sobre este último aplica-se o respectivo coeficiente de eficiência energética para eletricidade (MME, 2005) para a determinação da energia útil a ser substituída por gás. Então, considerando-se os respectivos coeficientes de eficiência energética com os gases

\section{SETORES DE AQUECIMENTO DIRETO E CALOR DE PROCESSO}

\section{ENERGIA ELÉTRICA}

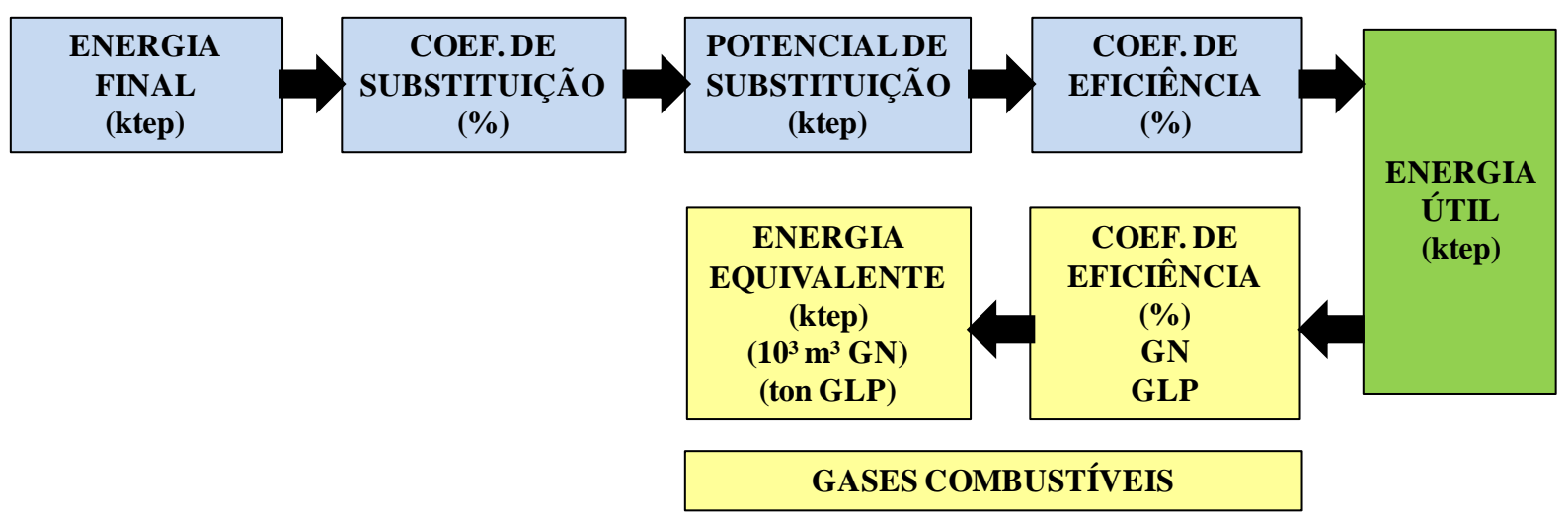

FIGURA 24 - Algoritmo para determinação da energia equivalente na conversão para gás Fonte: elaboração própria 
combustíveis (MME, 2005) encontra-se a energia equivalente substituta em gás natural e em GLP, nos blocos com a cor amarela.

Em aquecimento direto, este algoritmo foi utilizado na elaboração das Tabelas 14, 15, 16, 17 , $18,19,20,21$ e 22.

No aquecimento direto, a abordagem consiste na análise dos principais setores industriais que constam das planilhas do BEU 2005 (MME, 2005) - versão ampliada, a saber: Cimento, Ferro-Gusa e Aço, Ferro-Ligas, Mineração, Pelotização, Alumínio, Outros Metálicos (não ferrosos exceto alumínio), Química, Alimentos e Bebidas (excluindo Açúcar), Açúcar, Têxtil, Papel e Celulose, Cerâmica e Outros Setores Industriais.

\subsection{Rendimentos energéticos em AD}

O BEU 2005 (MME, 2005) apresenta um sumário dos rendimentos energéticos médios para o Aquecimento Direto, em seu item 4.3, para os setores de atividades, considerando as edições anteriores referentes aos anos de 1984 e 1994, de forma a mostrar a evolução até esta última edição com os dados de 2004.

A Tabela 11 mostra a evolução dos rendimentos energéticos e, também, os rendimentos de referência que consideraram o estado da arte dos equipamentos comercializados naquela ocasião para servir aos propósitos do benchmarking ${ }^{8}$.

Tabela 11 - Rendimentos de fornos elétricos

\begin{tabular}{lcccc}
\hline \multicolumn{4}{c}{ RENDIMENTO DE FORNOS ELÉTRICOS } \\
\hline \multicolumn{1}{c}{ SETORES INDUSTRIAIS } & 1984 & 1994 & 2004 & Referência \\
\hline Ferro Gusa e Aço & 0,500 & 0,550 & 0,600 & 0,700 \\
Ferro-ligas & 0,500 & 0,550 & 0,600 & 0,680 \\
Não ferrosos e outros metálicos & 0,520 & 0,550 & 0,600 & 0,700 \\
Química & 0,650 & 0,680 & 0,690 & 0,750 \\
Alimentos e Bebidas & 0,500 & 0,600 & 0,650 & 0,700 \\
Cerâmica & 0,500 & 0,550 & 0,580 & 0,620 \\
Outros & 0,450 & 0,500 & 0,550 & 0,550 \\
\hline
\end{tabular}

Fonte: Processamento FDTE, apud BEU (MME, 2005)

\footnotetext{
${ }^{8}$ Método comparativo que toma como base os melhores índices de determinado parâmetro, consagrados num setor, para ser utilizado como referência no processo de melhoria da gestão.
} 
A Tabela 12 apresenta a evolução dos rendimentos energéticos de fornos a combustíveis líquidos e gasosos. No escopo deste trabalho, tais rendimentos serão utilizados como referentes aos combustíveis gasosos.

Tabela 12 - Rendimentos de fornos a combustíveis gasosos

\begin{tabular}{lcccc}
\hline \multicolumn{4}{c}{ RENDIMENTO DE FORNOS A COMBUSTÍVEIS GASOSOS } \\
\hline \multicolumn{1}{c}{ SETORES INDUSTRIAIS } & \multicolumn{4}{c}{ RENDIMENTOS ENERGÉTICOS / ANO } \\
& 1984 & 1994 & 2004 & Referência \\
\hline Cimento & 0,370 & 0,430 & 0,460 & 0,510 \\
Ferro Gusa e Aço & 0,700 & 0,730 & 0,760 & 0,800 \\
Ferro-ligas & 0,500 & 0,540 & 0,560 & 0,600 \\
Mineração e Pelotização & 0,450 & 0,500 & 0,550 & 0,600 \\
Não ferrosos e outros metálicos & 0,520 & 0,550 & 0,600 & 0,650 \\
Química & 0,450 & 0,500 & 0,520 & 0,550 \\
Têxtil & 0,450 & 0,500 & 0,520 & 0,550 \\
Papel e Celulose & 0,400 & 0,430 & 0,460 & 0,450 \\
Alimentos e Bebidas & 0,450 & 0,500 & 0,520 & 0,550 \\
Cerâmica & 0,450 & 0,500 & 0,550 & 0,750 \\
Outros & 0,450 & 0,500 & 0,520 & 0,550 \\
\hline
\end{tabular}

Fonte: Processamento FDTE, apud BEU (2005)

Os rendimentos energéticos apresentados pela citada edição do BEU são passíveis de discussão pois deveriam significar os valores médios para cada setor industrial. Porém a heterogeneidade dos processos e equipamentos utilizados em Aquecimento Direto, associada à falta da informação do desvio padrão sobre a média considerada, pode gerar incertezas quanto a estes parâmetros.

\subsection{Potenciais de substituição da eletrotermia em AD por setor industrial}

Neste item são estimados os potenciais de substituição da eletrotermia por gases combustíveis para cada setor industrial, utilizando-se o algoritmo da Figura 24, as eficiências do BEU (MME, 2005), conceitos de profissionais do ramo, trabalhos acadêmicos e experiências do autor. 


\subsubsection{Indústria de cimento}

O setor de indústria de cimento caracteriza-se pelo uso intensivo do aquecimento direto para produção de sua principal matéria-prima, o clínquer, obtido através de fornos rotativos, onde a mistura crua sofre uma série de reações físicas e químicas, endotérmicas e exotérmicas, na medida em que sua temperatura se eleva progressivamente até a faixa de $1.450^{\circ}-1.500^{\circ} \mathrm{C}$ (MAGALHÃES, 2007). Este setor consumiu em 2012 o total de $5.320 \mathrm{ktep}$ em energia final, considerando todas as fontes de energia conforme o BEN (MME, 2013b).

Os energéticos destinados ao aquecimento direto, utilizados nos fornos rotativos, são combustíveis. O setor cimenteiro apresenta um perfil singular pois fez mudanças radicais ao longo das décadas na busca do energético disponível de mais baixo preço. Esta prática tornase obrigatória quando o produto não tem valor agregado e é energeticamente intensivo. Até a segunda crise do petróleo, o setor utilizava intensivamente o óleo BPF, posteriormente redenominado OC da série A (alto teor de enxofre) e subdividido em classes de viscosidades crescentes de 1 a 9, o qual foi substituído pelo carvão mineral e carvão vegetal na década dos anos 80. Este setor voltou temporariamente ao óleo combustível na década dos anos 90, quando o preço do petróleo regrediu para o patamar de US\$20/barril (valores nominais da ocasião), migrando para o coque de petróleo até os dias de hoje após a nova escalada de preços após a invasão do Kuwait pelo Iraque em 1990. Além disso, foram aproveitadas também as frações combustíveis contidas nos resíduos coprocessados nos fornos rotativos.

A Figura 25 mostra as variações radicais quanto ao uso de combustíveis por este setor, as quais não encontram similaridade em nenhum outro ramo de atividade industrial, característica essa que pode ser creditada em grande parte à adaptabilidade dos fornos rotativos neste particular. Não há, portanto, outro setor tão versátil para migrar rapidamente, com a experiência acumulada, para qualquer tipo de combustível como o setor da indústria de cimento.

O consumo de energia elétrica neste setor destina-se exclusivamente à força motriz (principalmente moinhos, esteiras transportadoras, acionamento dos fornos rotativos e dispositivos anti-poluição), não havendo nenhuma indicação no BEU 2005 quanto ao consumo de energia elétrica no ano de 2004 referente ao aquecimento direto. Portanto inexiste potencial para conversão da eletrotermia no tema desta tese. 


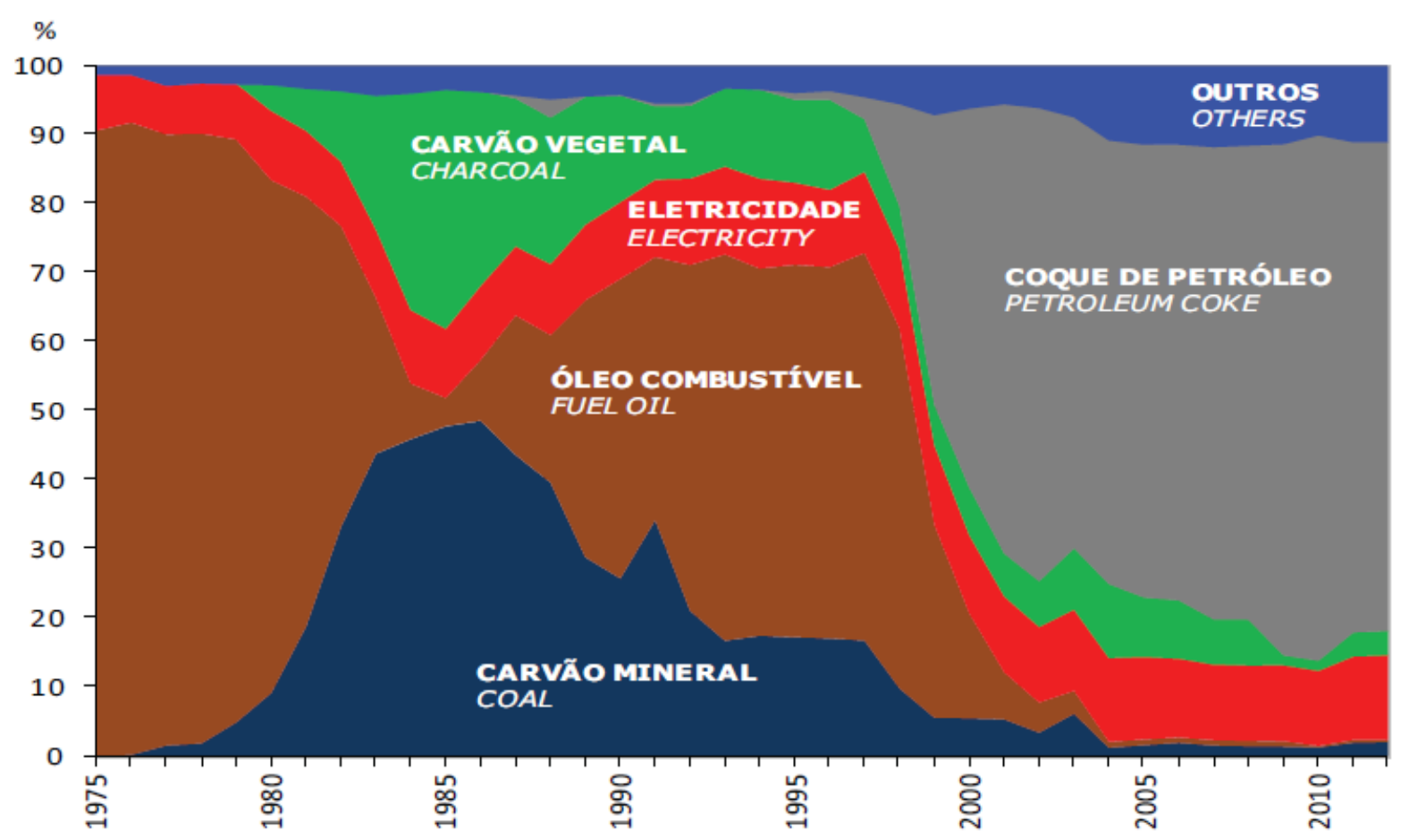

Figura 25 - Consumo de energéticos na indústria de cimento

Fonte: BEN (MME, 2013b)

\subsubsection{Indústria de ferro gusa e aço}

O setor de ferro gusa e aço abrange uma ampla gama de processos e, consequentemente, de fornos e energéticos diferentes, sendo o segundo setor mais energointensivo dos setores industriais, tendo consumido 16.790 ktep em 2012 conforme o BEN (MME, 2013b) sob todas as formas de energia.

Os processos na metalurgia primária, em siderúrgicas integradas, são: redução metalúrgica do minério para ferro gusa; conversão do ferro gusa para aço; lingotamento; laminação, trefilaria ou forjaria; e, em alguns casos, tratamento térmico. Nas siderúrgicas semi-integradas, o aço é produzido diretamente a partir de sucata de aço, ferro-gusa ou ferro-esponja em fornos elétricos a arco, passando pelas etapas da conformação a partir do lingotamento ou da forjaria, geralmente após a passagem por fornos de reaquecimento. No Brasil, a participação das siderúrgicas integradas (alto forno e $\mathrm{BOF}^{9}$ ) é de $76 \%$, enquanto as semi-integradas complementam os $24 \%$ restantes (MME-SGM, 2009d).

\footnotetext{
${ }^{9}$ BOF significa Basic Oxygen Furnace, equipamento siderúrgico que transforma o ferro-gusa em aço carbono, através da oxidação parcial do carbono contido no gusa com oxigênio.
} 
Também neste setor se enquadram as fundições e demais processos metalúrgicos, o que torna difícil a comparação entre os equipamentos, pois nem todos os fornos elétricos têm similares a gás.

Quanto ao consumo de energéticos por este setor, os processos e os equipamentos não permitem mudanças tão radicais como as observadas na indústria cimenteira, exceto a substituição dos óleos combustíveis por gás natural, como pode ser observado nas últimas décadas, na Figura 26.

Já o uso de coque metalúrgico e de carvão vegetal são indispensáveis na redução do minério de ferro, podendo ter seus consumos apenas minorados com o uso concomitante do gás natural como agente redutor nos altos-fornos.

De forma análoga, o consumo de energia elétrica nas siderúrgicas não integradas, em fornos elétricos a arco (FEA), é também indispensável, podendo somente ser minorado com o uso de queimadores auxiliares, conforme relatado mais detalhadamente no capítulo seguinte 5.2.2.1 Siderurgia.

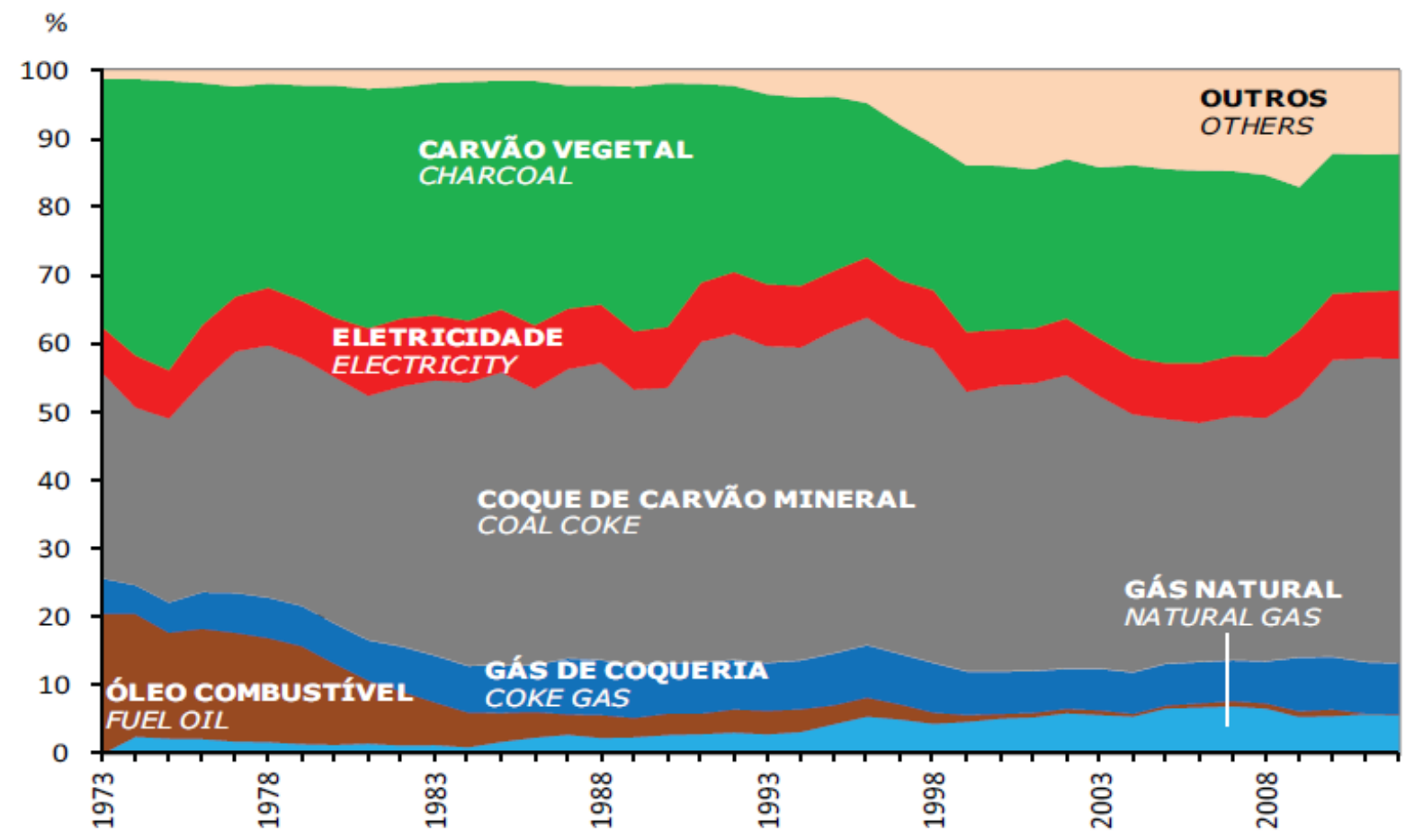

Figura 26 - Consumo de energéticos na indústria de ferro gusa e aço

Fonte: BEN (MME, 2013b) 


\subsubsection{Siderurgia}

Nos processos siderúrgicos, a única utilização significativa de eletrotermia são os fornos elétricos a arco (FEA) e os fornos-panela, equipamentos típicos das siderúrgicas semiintegradas.

A substituição dos fornos elétricos a arco por fornos a gás esbarra em problemas tecnológicos. Porém existe uma alternativa, já amplamente utilizada no Brasil e no mundo, que é a substituição parcial da energia elétrica por queimadores auxiliares, instalados no próprio FEA. Esta tecnologia passou a ser consagrada a partir da década dos anos 80, tornando-se tão eficiente que os principais fabricantes de fornos elétricos a arco passaram a oferecer estes equipamentos com os sistemas de queimadores, painéis de controle e sistemas supervisórios instalados e integrados no sistema operacional destes fornos. Como este tipo de forno não foi projetado para a queima de combustível e consequente tráfego dos produtos da combustão, não existe espaço livre para constituir uma câmara de combustão convencional. Deve-se levar em conta, ainda, que o momento ideal para fornecer energia suplementar ao FEA é o início da fusão de cada carga, quando todo o volume interior do forno está repleto de carga fria ou com um pequeno grau de preaquecimento. Portanto, a única forma de ser possível injetar energia de uma forma intensa e compacta é a utilização de queimadores do tipo oxi-combustível, os quais apresentam as seguintes vantagens:

- Elevada temperatura de chama, da ordem de $2.757^{\circ} \mathrm{C}$ (gás natural, condições adiabáticas) ou $2.821^{\circ} \mathrm{C}$ (GLP, condições adiabáticas), conforme já visto na Tabela 9 , fundindo quase instantaneamente o metal em contato com a chama, abrindo um volume vazio no interior da carga, incrementando assim o aquecimento, a fusão e o colapso da carga sólida, fora das posições dos três eletrodos, sobre o banho de aço líquido.

- Elevada velocidade de saída da mistura gás-oxigênio, para estabilizar a elevada velocidade de chama, provocando intensa turbulência nos meandros da carga.

- Geração de um baixo volume específico de produtos da combustão (PC), conforme já informado na Tabela 10 para a combustão do gás natural da Bolívia (GNB) e do GLP com ar e com oxigênio. 
Existem quatro posições preferenciais para a instalação dos queimadores no FEA: três locais no intervalo entre os eletrodos de grafite, conhecidos como pontos frios, e na porta de escória. A instalação dos queimadores dirigidos aos intervalos entre os eletrodos é feita através da carcaça, necessitando para isso modificar os painéis refrigerados quando o projeto original do forno não contemplou esta hipótese. Os queimadores devem ser instalados inclinados, no sentido descendente, de forma a ser evitado o contato da chama com os eletrodos, além de possibilitar um trajeto mais longo através da carga, incrementando a troca de calor, visto que a exaustão dos produtos da combustão se faz pela parte superior do forno. Já o queimador instalado na porta de escória deve ser instalado na posição horizontal ou ligeiramente inclinado para baixo.

A eficiência da aplicação dos queimadores oxi-gás é elevada enquanto a carga está fria e ocupando uma cota elevada no interior do forno. Na medida em que a carga vai baixando e se aquecendo, a eficiência diminui a ponto de não mais compensar o uso dos queimadores. Normalmente cada corrida do FEA necessita da alimentação de duas ou três cargas (cestas) de sucata de aço. Um parâmetro aproximado é usar os queimadores durante $50 \%$ do tempo de fusão de cada cesta. Porém esse parâmetro deve ser aprimorado conforme o tipo e o peso da sucata em cada carga, de forma a interagir automaticamente com as informações introduzidas no PLC que comanda o sistema.

Um perfil típico da aplicação de queimadores auxiliares oxi-gás está na Figura 27.

Além disso, diversas relações gás-oxigênio podem ser praticadas ao longo da corrida, de forma a usar os queimadores com atmosferas oxidantes para queimar as frações combustíveis que acompanham a carga, como resíduos oleosos, tinta etc., num processo chamado de póscombustão. Essa injeção adicional de oxigênio pode ser controlada através da análise contínua do teor de monóxido de carbono e hidrocarbonetos presentes na corrente dos gases de exaustão do FEA.

A instalação de um queimador oxi-gás na porta de escória proporciona, além do aquecimento direto, o desimpedimento desse espaço ocupado pela carga, possibilitando a entrada, se necessário, da lança de oxigênio (manual ou com manipulador).

Em algumas situações, a instalação do queimador apenas na porta de escória é o primeiro passo para iniciar os testes e colher alguns resultados. Isso porque a instalação dos três queimadores através dos painéis refrigerados é difícil de ser aceita numa tratativa inicial, além da necessidade de parar o FEA por alguns dias - o que significa lucros cessantes caso a programação da produção não o permita. 


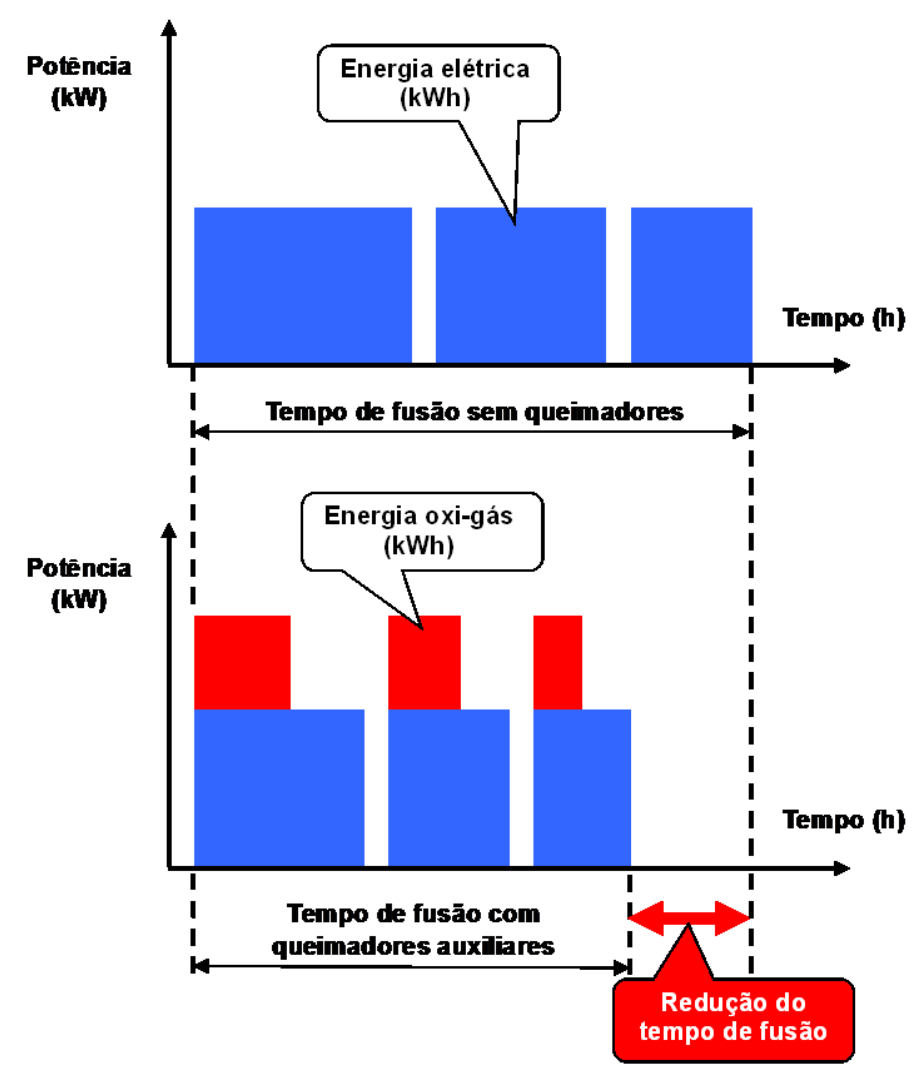

Figura 27 - Tempos de fusão em FEA com e sem queimadores auxiliares.

Fonte: elaboração própria

Os principais resultados que podem ser obtidos com o booster oxi-gás são os seguintes:

- Redução do tempo de fusão de cada cesto de sucata, implicando na redução do tempo total da corrida (tap-to-tap ${ }^{10}$ ). Isso possibilita o aumento de produtividade da aciaria, podendo influir na programação da produção em função do período da tarifa horosazonal.

- Redução nos consumos específicos da energia elétrica e dos eletrodos de grafite, em proporções semelhantes, referentes à tonelagem de aço produzida.

- Redução do consumo específico de refratário do FEA como função da tonelagem produzida.

\footnotetext{
${ }^{10} \mathrm{O}$ termo tap-to-tap no idioma inglês é um jargão habitualmente usado na siderurgia e nas fundições, inclusive no Brasil, que significa o tempo decorrido entre dois vazamentos de metal líquido consecutivos em um mesmo equipamento; assim são considerados os tempos decorridos em cada etapa deste processo, inclusive os tempos improdutivos.
} 
Algumas empresas fornecedoras de gases do ar, interessadas na venda de oxigênio, também estimulam e orientam as siderúrgicas na instalação de queimadores auxiliares, fornecendo o projeto, os equipamentos, acompanhando a partida, os testes e as avaliações iniciais, além do treinamento do pessoal de operação.

Cabe observar, ainda, que a implantação de queimadores auxiliares em FEA deve exigir um estudo prévio para verificar se o aumento de produtividade a ser obtido nestes fornos também pode ser absorvido por toda a cadeia de produção, desde a disponibilidade das matériasprimas (principalmente sucata) até o produto final e, também, pela demanda do mercado.

Algumas siderúrgicas utilizam o FEA apenas como uma máquina de fusão. As etapas seguintes de refino e condicionamento da temperatura do aço no estado líquido são realizadas em fornos-panela, que também são elétricos (eletrodos a arco, indução ou plasma). Como não há mais etapa de fusão nos fornos-panela, não é viável técnica nem economicamente a aplicação de queimadores oxi-gás, portanto sendo um processo exclusivamente eletrotérmico. Existem outros processos que, embora não possam ser considerados como conversão direta de eletrotermia para gás, contribuem para a redução do consumo de energia elétrica no FEA.

O primeiro processo refere-se ao preaquecimento das panelas que transportam o aço líquido do FEA até o local da sua conformação (lingotamento convencional ou lingotamento contínuo). Normalmente as panelas são preaquecidas em estações de aquecimento de certa forma distantes do FEA, necessitando do acoplamento e transporte de ponte rolante, o que causa perdas de, no mínimo, um minuto entre a saída da estação de reaquecimento e seu posicionamento junto à bica do FEA. Neste curto período de tempo as perdas térmicas da superfície interna do refratário da panela são significativas, podendo facilmente atingir valores superiores a $100^{\circ} \mathrm{C}$. A alternativa proposta é o preaquecimento da panela no próprio poço do FEA, na posição próxima da bica, de forma que a possibilitar o vazamento de aço sem que o refratário da panela perca temperatura. Uma das restrições para essa prática é que nem sempre o tempo da corrida, entre 40 e 60 minutos, é suficiente para o preaquecimento da panela com queimadores convencionais ar-gás ou ar-óleo. Caso o tempo de corrida seja inferior ao tempo necessário para o preaquecimento da panela com queimadores convencionais, esta alternativa deve ser complementada com a adoção de queimadores oxigás ou queimadores com ar de combustão enriquecido com oxigênio. Os resultados reais indicam que esta prática permite reduzir a temperatura exigida para o vazamento da corrida do aço em $10^{\circ}$ a $20^{\circ} \mathrm{C}$, pois tal superaquecimento do aço visa compensar a perda de temperatura devida à transferência de calor para o refratário da panela na prática 
convencional. Mas essa redução na temperatura máxima da corrida acarreta apenas em discretas reduções do tempo de corrida, do consumo de energia elétrica e do consumo de eletrodos.

O segundo processo é o preaquecimento da sucata de aço antes da sua alimentação no forno a arco. A sucata pode ser aquecida de duas formas: aproveitando-se parte do calor sensível contido nos gases efluentes do sistema de exaustão do próprio FEA; e utilizando-se da queima de gases combustíveis. Porém, todas as pesquisas têm sido conduzidas para o reaproveitamento do calor contido nos gases de exaustão do FEA, razão pela qual não será considerada esta possibilidade nesta pesquisa. O gráfico da Figura 28 foi plotado a partir dos calores específicos contidos na sucata preaquecida em função da temperatura, de acordo com Schmitt (1997).

Segundo Nakano, Arita e Uchida (1999), a partir de testes-piloto em 25\% da escala natural, reduções de consumo de energia elétrica em FEA podem atingir $80 \mathrm{kWh} / \mathrm{ton}$ aço preaquecendo a sucata a uma temperatura média de $600^{\circ} \mathrm{C}$; e que acima desta temperatura, inicia-se um lento processo de oxidação da carga o qual se torna significativo a partir de $800^{\circ} \mathrm{C}$, confirmando o trabalho de Schmitt (1997).

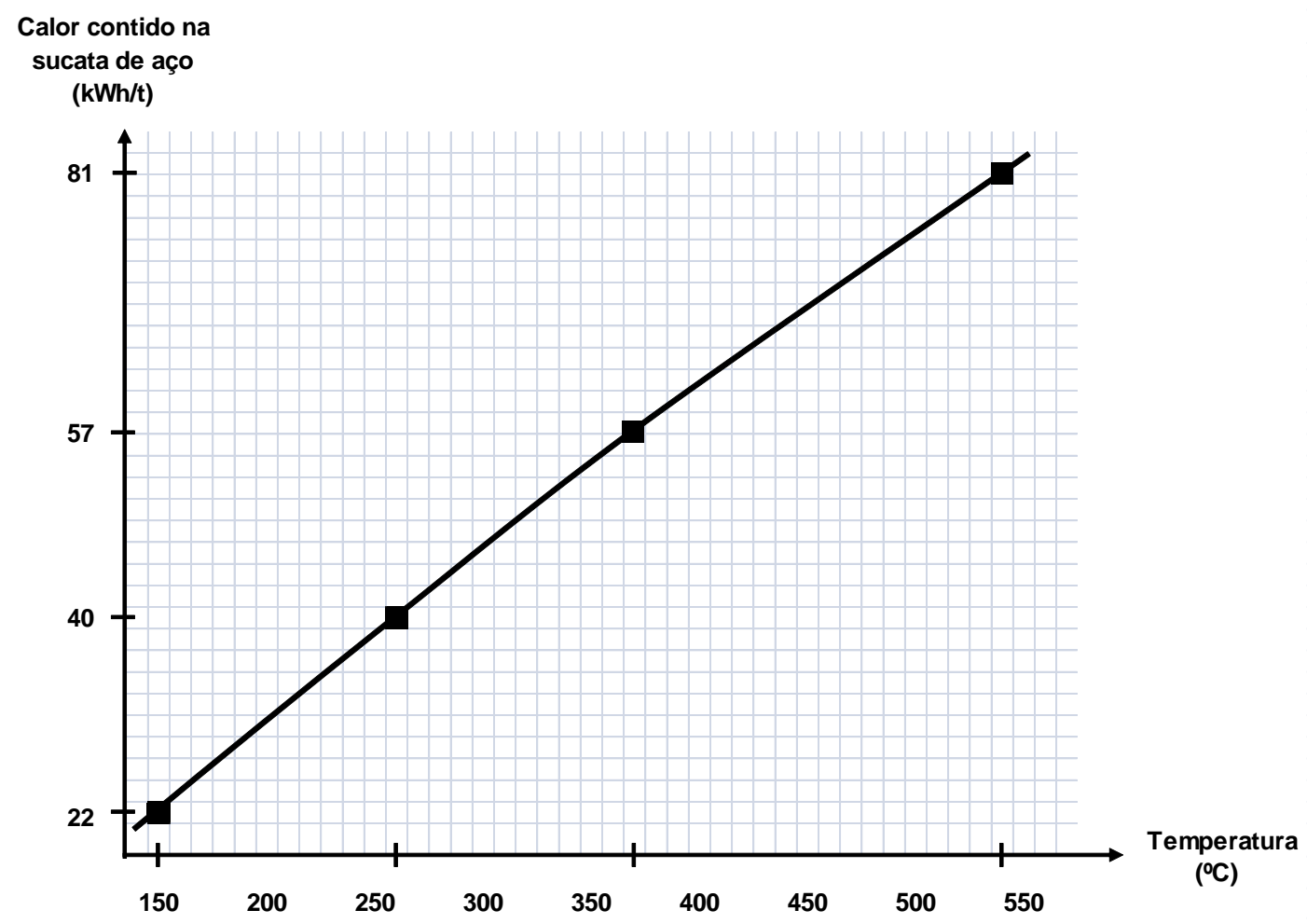

Figura 28 - Calor contido na sucata de aço em função da temperatura.

Fonte: Elaboração própria; Schmitt (1997) 
Considerando agora a produção brasileira de aço bruto em 2011, segundo o site do Instituto Aço Brasil (consulta em 22/09/2013), de 35.220,2 kton, das quais 8.231,4 kton produzidas por siderúrgicas semi-integradas, o potencial de economia com o preaquecimento de sucata a $600^{\circ} \mathrm{C}$ seria de:

8.231.400 ton $\mathrm{x} 80 \mathrm{kWh} /$ ton aço $=658,5 \mathrm{GWh}=56,6 \mathrm{ktep}$ (base 2011).

Porém este valor de 56,6 ktep não será considerado para substituição da eletrotermia neste setor, devido às pesquisas estarem sendo dirigidas ao aproveitamento dos efluentes térmicos oriundos dos próprios FEA, dispensando o consumo de combustíveis.

Considerando o consumo específico médio de energia elétrica do FEA igual a $345 \mathrm{kWh} / \mathrm{ton}$ aço a partir do ano 2000, segundo MME-SGM (2009d), e a produção brasileira de aço bruto em 2004, segundo IBS (2005), foi de 32.909 kton, sendo 6.498 kton produzidas por FEA, a energia elétrica consumida nesta aplicação do aquecimento direto seria:

6.498 .000 ton $\mathrm{x} 345 \mathrm{kWh} / \mathrm{ton}=2.241,8 \mathrm{GWh}=192,8 \mathrm{ktep}($ base 2004)

Dando sequência à cadeia produtiva, nos processos de laminação e forjaria para produzir laminados planos, perfis e forjados de aço, existem fornos de reaquecimento que tradicionalmente usavam óleos combustíveis mas tem migrado para o gás natural, não havendo seu correspondente elétrico nas siderúrgicas brasileiras. Na década dos anos 80 muitos fornos de reaquecimento na área de forjaria foram convertidos para energia elétrica em decorrência do incentivo do governo federal privilegiando fontes nacionais como decorrência da segunda crise do petróleo. Mas a maioria desses fornos já retornaram ao uso de combustíveis, principalmente óleo combustível ou gás natural, em função das incertezas quanto à disponibilidade da energia elétrica e de seus custos, sobretudo após a crise de 2001/2002.

\subsubsection{Fundições}

Ainda no setor de Ferro Gusa e Aço estão enquadradas as fundições para todos os tipos de aço carbono, aço inoxidável, aços-liga e ferro (branco, cinzento, nodular etc.). A Tabela 13 fornece as produções anuais das fundições de ferro e aço. 
Tabela 13 - Produção anual das fundições de ferro e aço

\begin{tabular}{|c|c|c|c|c|c|c|c|c|c|}
\hline \multicolumn{10}{|c|}{ PRODUÇÃO ANUAL DAS FUNDIÇÕES DE FERRO E AÇO (10³ ton) } \\
\hline & 2004 & 2005 & 2006 & 2007 & 2008 & 2009 & 2010 & 2011 & 2012 \\
\hline Ferro & $2.377,5$ & $2.436,2$ & $2.531,8$ & $2.690,0$ & $2.777,1$ & $1.917,9$ & $2.725,0$ & $2.799,2$ & $2.360,7$ \\
\hline Aço & 211,8 & 293,0 & 325,1 & 303,2 & 323,8 & 166,4 & 243,4 & 270,3 & 252,0 \\
\hline TOTAL & $2.589,3$ & $2.729,2$ & $2.856,9$ & $2.993,2$ & $3.100,9$ & $2.084,3$ & $2.968,4$ & $3.069,5$ & $2.612,7$ \\
\hline
\end{tabular}

Fonte: Elaboração própria; ABIFA (2013)

As grandes fundições de aço e ferro geralmente utilizam também fornos a arco elétrico, mas de menor porte do que os das siderúrgicas semi-integradas. Já as fundições de médio ou pequeno porte utilizam fornos de indução (elétrico), fornos rotativos (óleo ou gás), fornos EASA (óleo) ou fornos de cubilô (coque ou gás natural).

A utilização de fornos a óleos ou gases combustíveis é restrita às fundições de ferro. Quando se trata de qualquer tipo de aço é necessária a utilização de fornos elétricos, podendo ser utilizados queimadores auxiliares na etapa da fusão da carga.

As fundições que utilizam FEA tradicionalmente não possuem queimadores auxiliares, pois o compromisso com a produtividade não é tão intenso como nas siderúrgicas, as quais possuem uma cadeia de processos a ser alimentada a partir do lingotamento.

Contrariamente às fundições de aço, apenas no caso das fundições de ferro é possível substituir totalmente a energia que alimenta os fornos elétricos. As substituições totais de eletrotermia por gases combustíveis são realizadas por fornos rotativos de fusão ou fornos de cubilô, que tradicionalmente usam coque, ou no âmbito deste trabalho, por fornos de cubilô sem coque (cokeless cupola) a gás.

As substituições parciais em fornos elétricos podem ser realizadas de duas formas:

- usar queimadores auxiliares a gás, tanto nos fornos elétricos a arco como nos fornos de indução (ferro e aço), na etapa inicial da fusão da carga, reduzindo o consumo específico de energia elétrica e aumentando a produtividade;

- instalar fornos a gás para realizar a etapa da fusão (apenas ferro), como fornos de cubilô sem coque e fornos de fusão do tipo tambor rotativo, num processo conhecido como duplex, onde a fusão é feita a gás e o refino, o reaquecimento e/ou a manutenção 
de temperatura usa energia elétrica; além de substituir significativamente o consumo de energia elétrica por gás, é possível atingir um elevado aumento de produtividade.

O preaquecimento externo da carga em fundições, embora tecnicamente possível, não é praticado pela difícil viabilidade econômica dos investimentos, levando-se em conta a pequena escala de produção e as características artesanais do processo.

As experiências realizadas pelo autor na Fundição Curicica (Rio de Janeiro - RJ) e na Electrocast (Nova Odessa - SP), em 1988 e 1989 respectivamente, com a instalação de queimadores auxiliares oxi-gás em fornos de indução para ligas ferrosas (Figura 29), embora tenham apresentado resultados quanto o aumento da produtividade e redução do consumo específico de energia elétrica, não foram implantadas.

Os principais motivos para a não implantação definitiva deste processo dizem respeito às economias finais não terem se mostrado atrativas e à falta de interesse dos operadores dos fornos em se adaptarem à nova modalidade de operação.

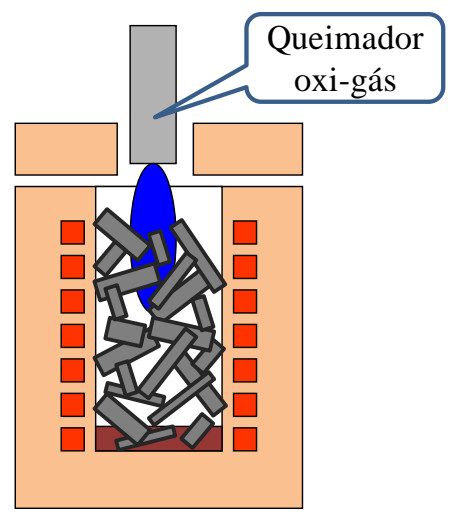

Figura 29 - Esquema do queimador oxi-gás em forno de indução Fonte: elaboração própria

Foram também realizados, a partir de abril de 2000, testes no setor de fundição da empresa Metso (Sorocaba - SP) com a operação de um queimador oxi-GLP móvel através da porta de escória de um FEA.

A Figura 30 mostra um queimador móvel operando em FEA, na Siderúrgica Fiel nos anos 80, na primeira experiência neste tipo de forno realizada pelo autor no Brasil. 


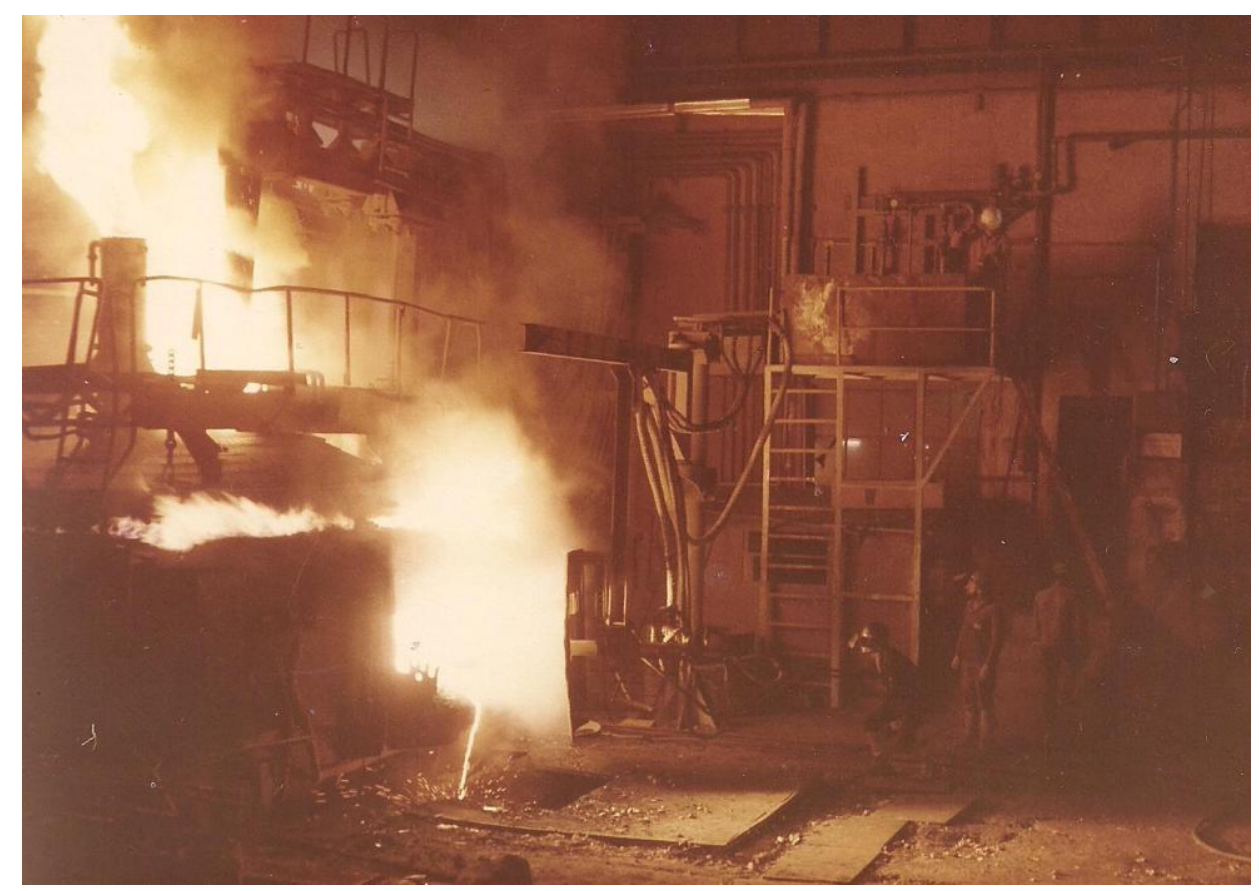

Figura 30 - Queimador móvel operando em FEA

Fonte: foto do acervo do autor

Além da avaliação da substituição parcial do consumo de energia elétrica por GLP e oxigênio na Metso, os ensaios objetivaram a redução do tempo da corrida (aumento de produtividade) e a observação do comportamento do rendimento metalúrgico no que diz respeito à oxidação de elementos-liga, principalmente manganês neste caso. Para os ensaios foram escolhidas as duas ligas metálicas mais produzidas, onde foram acompanhadas 69 corridas sem queimador, para tomada de dados de referência, sendo posteriormente realizadas 23 corridas com o queimador. Os resultados médios foram: redução do consumo específico de 510 para $405 \mathrm{kWh} / \mathrm{ton}$ (economia de 20,6\%) e redução do tempo de corrida de 225 para 187 minutos. Apesar dos promissores resultados técnicos obtidos, o sistema não foi implantado pelos seguintes motivos: o custo do pacote energético, GLP e oxigênio, em comparação com a energia elétrica, não apresentava uma economia significativamente atrativa; e o aumento de produtividade se diluía no tipo de operação de uma fundição, onde tempos mortos existem. Cabe ressaltar ainda que uma fundição, não sendo grande consumidora de oxigênio, não pode se beneficiar dos baixos preços praticados nas siderúrgicas. Posteriormente o GLP foi substituído pelo GN e o autor, em contato com o pessoal da Metso, foi informado que o queimador ainda é eventualmente utilizado em situações estratégicas como pequenos apagões e adiantamento de corrida quando ocorre atraso na programação ou para evitar a operação em 
horário de ponta. Porém seu uso é apenas eventual e não gera portanto economias mensuráveis.

A energia final no aquecimento direto em eletricidade, no setor de indústria de ferro gusa e aço, em 2004, indica o valor de 78,4 ktep (BEU, 2005) ou 911,6 GWh. Conforme calculado anteriormente, a energia final em aquecimento direto neste setor, considerando apenas o consumo das siderúrgicas semi-integradas seria de 2.241,8 GWh ou 192,8 ktep. A este valor deveria ainda ser adicionado o consumo de energia elétrica, em aquecimento direto, referente a todas as fundições deste setor, que englobam fornos de fusão (a arco e de indução) e fornos de tratamento térmico. Porém o valor indicado pelo BEU (MME, 2005) para o ano de 2004 de apenas 78,4 ktep parece inconsistente por ser muito inferior ao consumo considerando-se apenas as siderúrgicas semi-integradas.

Este setor de Ferro Gusa e Aço deveria ser subdividido pois engloba indústrias de gêneros significativamente diferentes, como as siderúrgicas integradas a coque, as siderúrgicas integradas a carvão vegetal e as siderúrgicas semi-integradas (FEA), além das fundições de ferro e aço, que apresentam processos e porte significativamente diferentes, o que mascara os resultados consolidados neste setor do BEU (MME, 2005). Assim, não é possível analisar cada um dos citados setores independentemente, de forma a fazer estimativas para o potencial de substituição da eletrotermia por gases combustíveis.

O BEU, apesar de ser a melhor publicação disponível no Brasil, processando as informações setoriais do BEN e fornecendo as estimativas da energia final e da energia útil para cada setor através dos coeficientes de eficiência energética, pode apresentar resultados destorcidos, devido às limitações inerentes à escassez e à heterogeneidade das fontes de referência, como neste caso da indústria de ferro-gusa e aço.

No Anexo A, segue a Instrução Normativa CNP / DIPLAN nº 01/84 e o Manual de Orientação da Pesquisa de Consumo de Energia - edição de 1984, o qual mostra a riqueza de informações solicitadas às empresas que consumiam ou iriam consumir mais de 500 toneladas de óleo combustível ou $5.200 \mathrm{Gcal} /$ ano em quaisquer fontes de energia, naquela época, constituindo um requisito obrigatório para a obtenção de quotas para aquisição de derivados de petróleo.

Esta filosofia de pesquisa poderia servir de inspiração para a elaboração de uma planilha eletrônica a ser preenchida pelas indústrias e entregue ao MME ou EPE. Além de servir como base para os propósitos do planejamento energético governamental, esta planilha seria uma ferramenta útil para a própria indústria, permitindo acompanhar a evolução dos consumos 
específicos de energéticos em cada processo, podendo até contribuir com o levantamento de dados para a certificação segundo a norma ISO-50001 e estudos com objetivo da conservação de energia.

\subsubsection{Indústria de ferro-ligas}

O setor de ferro-ligas consumiu, em 2012, o total de 1.565 ktep sob todas as formas de energia (MME, 2013b). A produção de aços em geral, bem como a de aços especiais e açosliga destacadamente se caracterizam pela necessidade de uma matéria-prima de alto valor: ferro-ligas, os quais conferem propriedades especiais aos aços. Dentre as funções dos elementos-liga nos aços destacam-se o aumento das resistências à corrosão, à abrasão e à tração em altas temperaturas, além de proporcionarem propriedades magnéticas, elétricas, de soldabilidade e de tenacidade. Portanto, o mercado de ferro-ligas está vinculado basicamente à produção das siderúrgicas e das fundições.

Este setor engloba uma grande variedade de produtos, principalmente as ligas de ferromanganês, ferro-silício, ferro-cromo, ferro-cromo-silício e as ligas mais nobres como ferromolibdênio, ferro-tungstênio, ferro-vanádio, ferro-silício-magnésio, ferro-titânio, ferro-nióbio e ferro-boro.

O setor de ferro-ligas é usuário intensivo de energia elétrica nos processos de aquecimento direto e redução metalúrgica, sendo este energético uma significativa parcela do custo de produção. Os consumos específicos de energia elétrica variam significativamente em função do tipo do ferro-liga que está sendo considerado. No Brasil, segundo Bermann (2001), o consumo específico varia de 3.300 a $13.500 \mathrm{kWh} /$ ton de ferro-liga. O valor médio em 2011 toma por base o consumo de 854.000 toneladas e o consumo de energia elétrica de 7.334 GWh (MME, 2012) ou 630.724 tep, resultando em 8.588 kWh/ton. Na Índia, segundo Indian (2009), o consumo específico de energia elétrica varia de 3.000 a $12.000 \mathrm{kWh} / \mathrm{ton}$, significando de $40 \%$ a $70 \%$ dos custos de produção. O país que lidera as exportações mundiais de ferro-ligas é a África do Sul, devido à disponibilidade dos minérios e baixo custo da energia elétrica (Basson, 2007).

Segundo Rennie (2004), o preaquecimento e/ou a pré-redução com gás natural tem reduzido o consumo de energia elétrica, muito embora a alta concentração de energia necessária para o processo de redução só possa ser obtida com o emprego de correntes elétricas elevadas. 
As possíveis substituições da eletrotermia neste setor seriam realizadas indiretamente através do preaquecimento do minério antes da alimentação no forno a arco submerso. As economias de energia elétrica com o preaquecimento do minério a $900^{\circ} \mathrm{C}$, sendo alimentado no forno a arco submerso a $800^{\circ} \mathrm{C}$, podem atingir valores da ordem de $20 \%$, segundo McCullough et al. (2010).

De acordo com o BEU (MME, 2005), ano base 2004, não foi relatado calor de processo pois praticamente inexiste neste setor de atividade. Já o aquecimento direto consumiu a energia final correspondente a 1.540,3 ktep, das quais 635,7 ktep referem-se à energia elétrica e 664,4 ktep ao coque de carvão mineral e ao carvão vegetal. A energia útil, referente ao uso da eletricidade no aquecimento direto, foi de $381,4 \mathrm{ktep}$, o que significa um rendimento térmico de $60,0 \%$.

A Tabela 14 apresenta o potencial teórico para substituição da eletrotermia por gases combustíveis, considerando os respectivos coeficientes de eficiência energética. Como única alternativa viável no processo é a substituição parcial da energia elétrica aplicando-se o preaquecimento do minério com gás combustível, o potencial considerou a premissa de McCullough et al. (2010) de 20\%. Assim, este potencial de economia de energia elétrica, considerando a energia final, seria de 1.477,9 GWh/ano (base 2004) ou 127,1 ktep.

Tabela 14 - Substituição de eletrotermia em AD na indústria de ferro-ligas

\begin{tabular}{|c|c|c|c|c|c|c|c|}
\hline \multicolumn{8}{|c|}{ INDÚSTRIA DE FERRO-LIGAS - AQUECIMENTO DIRETO - BASE 2004} \\
\hline \multicolumn{5}{|c|}{ ENERGIA ELÉTRICA } & \multicolumn{3}{|c|}{ GASES COMBUSTÍVEIS } \\
\hline FINAL & $\begin{array}{l}\text { COEF. DE } \\
\text { SUBSTIT }\end{array}$ & $\begin{array}{l}\text { POTENCIAL } \\
\text { SUBSTIT }\end{array}$ & $\begin{array}{l}\text { COEF. } \\
\text { EFIC }\end{array}$ & $\begin{array}{c}\text { ENERGIA } \\
\text { SUBST, ÚTUL }\end{array}$ & $\begin{array}{l}\text { COEF. } \\
\text { EFIC. }\end{array}$ & ENER & A EQUIVALENTE \\
\hline (1.000 tep) & (\%) & (1.000 tep) & $(\%)$ & (1.000 tep) & (\%) & (1.000 tep) & (unidade comercial) \\
\hline \multirow{2}{*}{635,7} & \multirow{2}{*}{20,0} & \multirow{2}{*}{127,1} & \multirow{2}{*}{ 60,0 } & \multirow{2}{*}{76,3} & 56,0 & 136,2 & $154.797 \times 10^{3} \mathrm{~m}^{3} \mathrm{GN}$ \\
\hline & & & & & 56,0 & 136,2 & 122.722 ton GLP \\
\hline
\end{tabular}

Fonte: elaboração própria, a partir de dados do BEU (2005)

\subsubsection{Indústria de mineração}

O setor de mineração abrange a exploração e beneficiamento de minerais, destacando-se as seguintes produções em tonelagem no ano de 2008: 496 Mt de agregados (areia e brita); 351 Mt de minério de ferro, 140 Mt de argila para cerâmica vermelha (MME, 2010) e $105 \mathrm{Mt}$ calcário (MME-SGM, 2009c). O consumo energético totalizou, em 2012 e juntamente com o 
setor de pelotização, o valor de 3.188 ktep (MME, 2013b) considerando todas as formas de energia.

Após a exploração, o próximo passo é o beneficiamento do minério, de forma a prepará-lo para o processamento, separando a ganga (substâncias que não contem metal ou que possuam teor insuficiente) do minério. Segundo o MME (2008), os principais processos de beneficiamento são:

- fragmentação;

- classificação;

- concentração (separação/concentração gravimétrica, separação magnética, flotação ou seleção manual).

Os referidos processos utilizam energia elétrica em praticamente todos esses processos, mas não como eletrotermia e sim para força motriz, como moagem, bombeio de água, transporte em esteiras, vibradores e geração de campos magnéticos. Os processos térmicos, como secagem e calcinação utilizam, na sua grande maioria, combustíveis como fonte de calor, principalmente óleos combustíveis.

A demanda energética para força motriz, utilizando a eletricidade e o óleo diesel, significa $55,5 \%$ do total da energia final total segundo o BEU (MME, 2005). O uso de eletricidade para aquecimento direto é relativamente pequeno, totalizando 30,0 ktep ou 348,8 GWh no ano de 2004 (MME, 2005), representando 8,4\% da energia final, e não há referências quanto aos tipos de uso nesta modalidade. Os coeficientes de eficiência energética para todos os vetores energéticos indicados no BEU (MME, 2005) foram de 0,550, o que leva a supor o desconhecimento das aplicações em aquecimento direto.

Neste setor, foi usada a referência de Strapassom (2004), considerando a estimativa agressiva tomada como referência o Reino Unido, onde o coeficiente de substituição pode alcançar 100\%, como indicado na Tabela 15.

Tabela 15 - Substituição de eletrotermia em AD na indústria de mineração

\begin{tabular}{|c|c|c|c|c|c|c|c|}
\hline \multicolumn{8}{|c|}{ INDÚSTRIA DE MINERAÇÃO - AQUECIMENTO DIRETO - BASE 2004} \\
\hline \multicolumn{5}{|c|}{ ENERGIA ELÉTRICA } & \multicolumn{3}{|c|}{ GASES COMBUSTÍVEIS } \\
\hline & $\begin{array}{l}\text { COEF. DE } \\
\text { SUBSTIT. }\end{array}$ & $\begin{array}{c}\text { POTENCIAL } \\
\text { SUBSTIT. }\end{array}$ & $\begin{array}{l}\text { COEF. } \\
\text { EFIC. }\end{array}$ & $\begin{array}{c}\text { ENERGIA } \\
\text { SUBST. ÚTIL }\end{array}$ & $\begin{array}{l}\text { COEF. } \\
\text { EFIC. }\end{array}$ & ENE & A EQUIVALENTE \\
\hline (ktep) & (\%) & (ktep) & $(\%)$ & (ktep) & (\%) & (ktep) & (unidade comercial) \\
\hline $\mathbf{3 0 , 0}$ & 100,0 & $\mathbf{3 0 , 0}$ & 60,0 & 18,0 & 56,0 & 32,1 & $36.526 \times 10^{3} \mathrm{~m}^{3} \mathrm{GN}$ \\
\hline & & & & & 56,0 & 32,1 & 28.958 ton GLP \\
\hline
\end{tabular}

Fonte: elaboração própria, a partir de dados do BEU (MME, 2005) 


\subsubsection{Indústria de pelotização}

O setor de pelotização foi desagregado do setor de mineração na versão ampliada do BEU (MME, 2005), por apresentar características peculiares, o qual totalizou a produção de $55 \mathrm{Mt}$ em 2008 (MME, 2010). O uso de eletricidade para aquecimento direto neste setor é ainda menor do que o da mineração, sendo apenas 1,5 ktep ou 17,4 GWh no ano de 2004 segundo o BEU (MME, 2005), correspondendo a apenas 0,13\% do total em aquecimento direto. De forma análoga às considerações do setor de mineração, os coeficientes de eficiência energética padronizados em 0,550 nos leva a supor o desconhecimento das aplicações dos vetores energéticos em aquecimento direto.

O consumo da energia final de 523,8 ktep em 2004 (MME, 2005) em óleo combustível no aquecimento direto sugere que uma parte significativa do consumo de energia elétrica e de óleos combustíveis em calor de processo seja aplicada no aquecimento destes óleos para bombeio e atomização. O aquecimento de 523,8 ktep consome, considerando o calor específico médio de $0,5 \mathrm{kcal} / \mathrm{kg} .{ }^{\circ} \mathrm{C}$, a diferença de temperaturas de $100^{\circ} \mathrm{C}$, o rendimento de 0,70 (supondo-se equivalente a um boiler elétrico) e o PCI do óleo combustível igual a 9.590 $\mathrm{kcal} / \mathrm{kg}$ (ANP, 2012):

Energia útil: $\quad\left(0,5 \mathrm{kcal} / \mathrm{kg}\right.$ óleo. $\left.{ }^{\circ} \mathrm{C}\right) \times 100^{\circ} \mathrm{C}=50,0 \mathrm{kcal} / \mathrm{kg}$ óleo

Energia final: $50,0 \mathrm{kcal} / \mathrm{kg} / 0,70=71,4 \mathrm{kcal} / \mathrm{kg}$ óleo

1 tep $=10.000 .000 / 9.590 .000=1,0428$ t óleo combustível

1tep sob a forma óleo combustível consome para seu aquecimento:

$71,4 \mathrm{kcal} / \mathrm{kg} \times 1.042,8 \mathrm{~kg}$ óleo combustível $=74.456 \mathrm{kcal}=0,0074456$ tep.

Assim, de acordo com esta suposição, os óleos combustíveis aplicados em aquecimento direto (523,8 ktep) consumiriam 3,9 ktep de energia final para seu aquecimento. Esta ordem de grandeza permite aceitar a hipótese que as energias finais em calor de processo com óleos combustíveis (3,2 ktep) e em aquecimento direto com eletricidade (1,5 tep) devam participar da aplicação de aquecimento dos óleos combustíveis usados em aquecimento direto.

Desta forma foi considerada a estimativa do coeficiente de substituição de $100 \%$, como indicado na Tabela 16. 
Tabela 16 - Substituição de eletrotermia em AD na indústria de pelotização

\begin{tabular}{|c|c|c|c|c|c|c|c|}
\hline \multicolumn{8}{|c|}{ INDÚSTRIA DE PELOTIZAÇÃO - AQUECIMENTO DIRETO - BASE 2004} \\
\hline \multicolumn{5}{|c|}{ ENERGIA ELÉTRICA } & \multicolumn{3}{|c|}{ GASES COMBUSTÍVEIS } \\
\hline $\begin{array}{l}\text { FINAL } \\
\text { (ktep) }\end{array}$ & $\begin{array}{c}\text { COEF. DE } \\
\text { SUBSTIT. } \\
(\%)\end{array}$ & $\begin{array}{c}\text { POTENCIAL } \\
\text { SUBSTIT. } \\
\text { (ktep) }\end{array}$ & $\begin{array}{c}\text { COEF. } \\
\text { EFIC. } \\
(\%)\end{array}$ & $\begin{array}{c}\text { ENERGIA } \\
\text { SUBST. ÚTIL } \\
\text { (ktep) }\end{array}$ & $\begin{array}{l}\text { COEF. } \\
\text { EFIC. } \\
(\%)\end{array}$ & $\begin{array}{l}\text { ENEI } \\
\text { (ktep) }\end{array}$ & $\begin{array}{l}\text { A EQUIVALENTE } \\
\text { (unidade comercial) }\end{array}$ \\
\hline 1,5 & 100,0 & 1,5 & 70,0 & 1,1 & $\begin{array}{l}56,0 \\
56,0\end{array}$ & $\begin{array}{l}1,9 \\
1,9\end{array}$ & $\begin{array}{l}2.131 \times 10^{3} \mathrm{~m}^{3} \mathrm{GN} \\
1.689 \text { ton GLP }\end{array}$ \\
\hline
\end{tabular}

Fonte: elaboração própria, a partir de dados do BEU (MME, 2005)

Obs.:

O coeficiente de eficiência de $70 \%$ com energia elétrica baseou-se nos aquecedores de óleos combustíveis para esta finalidade, que operam na faixa de $100^{\circ}$ a $130^{\circ} \mathrm{C}$.

O coeficiente de eficiência de 56\% considerou o aquecimento dos aquecedores de óleos combustíveis com vapor, onde a eficiência foi estimada em $80 \%$ (geração de vapor) de $70 \%$ (eficiência do aquecedor).

Fonte: elaboração e cálculos próprios, a partir de dados do BEU (2005)

\subsubsection{Indústria de alumínio}

Este setor consumiu, juntamente com o setor de outros produtos metálicos, a energia total de 6.969 ktep em 2012 (MME, 2013b), considerando todas as formas de energia.

A indústria de alumínio se subdivide em duas cadeias produtivas: cadeia primária e cadeia secundária. A cadeia primária parte da alumina, oriunda da mineração da bauxita, através de processo de redução metalúrgica onde o principal e insubstituível insumo é a energia elétrica (aplicação eletroquímica). E a cadeia secundária parte do alumínio, o qual pode ser oriundo da cadeia primária, tanto na fase líquida como sob a forma de lingotes, ou ainda a partir de sucata interna (rejeitos de produção) e de sucata externa através de uma grande rede de reciclagem.

Neste setor, os consumos de eletricidade indicados no BEU (MME, 2005) separa o elevado consumo eletroquímico da cadeia primária, permitindo concluir que o consumo atribuído ao aquecimento direto esteja relacionado com os processos de fusão, de preaquecimento para conformação e de tratamento térmico.

Curiosamente neste setor, em 2004, o coeficiente de eficiência energética da eletricidade em aquecimento direto é 0,550 enquanto que para GN e GLP é 0,600. Isso indica que, certamente, predominam processos diferentes para eletricidade e gás, provavelmente com a existência de mais fornos de fusão elétricos e mais fornos de tratamento térmico e aquecimento para conformação a gás. Por esta razão, nos cálculos da substituição da eletrotermia por gás combustível será considerada a eficiência com GN e GLP igual a 0,500, 
assumindo-se uma diferença igual à dos coeficientes de eficiência de referência entre energia elétrica $(0,700)$ e gases combustíveis $(0,650)$.

Assim, como teoricamente todos estes processos eletrotérmicos do aquecimento direto podem ser convertidos para gases combustíveis, o potencial coincide com os valores indicados na Tabela 17, ou seja, substituindo 444,6 ktep ou 5.193 GWh segundo a referência de 2004 (MME, 2005).

Tabela 17 - Substituição de eletrotermia em AD na indústria de alumínio

\begin{tabular}{|c|c|c|c|c|c|c|c|}
\hline \multicolumn{8}{|c|}{ INDÚSTRIA DE ALUMÍNIO - AQUECIMENTO DIRETO - BASE 2004} \\
\hline \multicolumn{5}{|c|}{ ENERGIA ELÉTRICA } & \multicolumn{3}{|c|}{ GASES COMBUSTÍVEIS } \\
\hline $\begin{array}{l}\text { FINAL } \\
\text { (ktep) }\end{array}$ & $\begin{array}{c}\text { COEF. DE } \\
\text { SUBSTIT. } \\
\text { (\%) }\end{array}$ & $\begin{array}{c}\text { POTENCIAL } \\
\text { SUBSTIT. } \\
\text { (ktep) }\end{array}$ & $\begin{array}{c}\text { COEF. } \\
\text { EFIC. } \\
(\%)\end{array}$ & $\begin{array}{c}\text { ENERGIA } \\
\text { SUBST. ÚTIL } \\
\text { (ktep) }\end{array}$ & $\begin{array}{c}\text { COEF. } \\
\text { EFIC. } \\
(\%)\end{array}$ & $\begin{array}{l}\text { ENEI } \\
\text { (ktep) }\end{array}$ & $\begin{array}{l}\text { A EQUIVALENTE } \\
\text { (unidade comercial) }\end{array}$ \\
\hline 444,6 & 100,0 & 444,6 & 55,0 & 244,5 & $\begin{array}{l}50,0 \\
50,0\end{array}$ & $\begin{array}{l}489,1 \\
489,1\end{array}$ & $\begin{array}{l}555.750 \times 10^{3} \mathrm{~m}^{3} \mathrm{GN} \\
440.595 \text { ton } \mathrm{GLP}\end{array}$ \\
\hline
\end{tabular}

Fonte: elaboração própria, a partir de dados do BEU (MME, 2005)

\subsubsection{Indústria de outros produtos metálicos}

Este setor engloba outros produtos metálicos, ou seja, metais não ferrosos excluindo alumínio, como cobre, cromo, zinco, chumbo, antimônio, magnésio, titânio e suas ligas. Algumas dessas ligas podem conter ferro em pequenas percentagens mas, mesmo assim, pertencem ao grupo dos metais não ferrosos.

A metalurgia primária é aquela cuja matéria prima é retirada da natureza, onde os metais se encontram associados a outros elementos, sob a forma de óxidos, sulfetos, sulfatos, silicatos e, algumas vezes, associado a outros metais. Isto se deve ao processo de formação, durante o resfriamento do planeta, onde os metais foram reagindo quimicamente de forma a se estabilizarem nos pontos mais baixos de energia, constituindo os minérios.

Após o beneficiamento do minério, este está pronto para iniciar o processo de obtenção do metal através de uma grande diversidade de processos. Os minérios que se encontram sob a forma de óxidos necessitam passar por um processo de redução metalúrgica, seja por redução eletrolítica ou por gás redutor como hidrogênio e monóxido de carbono, onde se incluem também alguns sulfetos.

Já os processos da metalurgia secundária partem do metal ou suas ligas metálicas, cujas fontes podem ser a produção através da metalurgia primária, no estado líquido ou sob a forma de 
lingotes, pela reciclagem de sucata interna (resíduos do processamento) ou pela compra de sucata externa. Em alguns metais, a sucata externa vem acompanhada de óxidos, sulfatos e outros compostos, como o chumbo oriundo de baterias inservíveis de veículos automotores, exigindo sua redução metalúrgica e operações de refino para obtenção do metal, além das correções para obtenção da liga desejada.

Curiosamente as aplicações do aquecimento direto neste setor, bem como no setor de alumínio, apresentaram eficiências mais elevadas com combustíveis fósseis do que com a energia elétrica. Porém, a falta de detalhamento do BEU (MME, 2005) neste particular não permite comparar os processos e equipamentos, de forma a permitir uma comparação dos custos dos energéticos visando a conversão da eletrotermia para gás combustível.

Neste setor existem muitas oportunidades para conversão de eletrotermia, como a substituição total de fornos de fusão e aquecimento a indução ou resistências elétricas por fornos a gás (cadinho, revérbero, pera e rotativo), e a conversão para gás de fornos de reaquecimento para conformação e de tratamento térmico a resistências elétricas com a instalação de queimadores. A substituição parcial da eletricidade em fornos de fusão a indução, com o preaquecimento da carga e a instalação de queimadores auxiliares, embora tecnicamente possível, apresenta os mesmos problemas de ordem prática e econômica já citados em 5.2.2.2 - Fundições.

Neste setor, apesar de existir um grande número de processos diferentes, o valor indicado no BEU (MME, 2005) para o consumo de eletricidade (energia final) no aquecimento direto referem-se a processos de fusão, de preaquecimento para conformação e de tratamento térmico, totalizando 284,4 ktep ou 3.307,0 GWh no ano de 2004, o qual pode ser considerado como potencial de conversão para gases combustíveis conforme indicado na Tabela 18.

De forma análoga e pelos mesmos motivos relatados no setor de alumínio, o coeficiente de substituição considerado foi $100 \%$ e os coeficientes de eficiência com GN e GLP foram considerados como 0,500 .

Tabela 18 - Substituição de eletrotermia em AD na indústria de outros produtos metálicos

\begin{tabular}{|c|c|c|c|c|c|c|c|}
\hline \multicolumn{8}{|c|}{ INDÚSTRIA DE OUTROS PRODUTOS METÁLICOS - AQUECIMENTO DIRETO - BASE 2004} \\
\hline \multicolumn{5}{|c|}{ ENERGIA ELÉTRICA } & \multicolumn{3}{|c|}{ GASES COMBUSTIIVEIS } \\
\hline & $\begin{array}{l}\text { COEF. DE } \\
\text { SUBSTIT. }\end{array}$ & $\begin{array}{l}\text { POTENCIAL } \\
\text { SUBSTIT. }\end{array}$ & $\begin{array}{l}\text { COEF. } \\
\text { EFIC. }\end{array}$ & $\begin{array}{c}\text { ENERGIA } \\
\text { SUBST. ÚTIL }\end{array}$ & $\begin{array}{l}\text { COEF. } \\
\text { EFIC. }\end{array}$ & ENE & A EQUIVALENTE \\
\hline (ktep) & (\%) & (ktep) & $(\%)$ & (ktep) & (\%) & (ktep) & (unidade comercial) \\
\hline 284,4 & 100,0 & 284,4 & 55,0 & 156,4 & $\begin{array}{l}\mathbf{5 0 , 0} \\
\mathbf{5 0 , 0}\end{array}$ & $\begin{array}{l}312,8 \\
312,8\end{array}$ & $\begin{array}{l}355.500 \times 10^{3} \mathrm{~m}^{3} \mathrm{GN} \\
281.838 \text { ton GLP }\end{array}$ \\
\hline
\end{tabular}

Fonte: elaboração própria, a partir de dados do BEU (MME, 2005) 


\subsubsection{Indústria química}

O setor de química é o quarto maior consumidor de energia no setor industrial, totalizando 7.482 ktep em 2012 (MME, 2013b), em todas as formas de energia. Mas a energia final em aquecimento direto neste setor é pouco significativa, correspondendo a 460,8 ktep, ou seja, 6,5\% do consumo total de 7.115,3 ktep em 2004 (MME, 2005), onde a eletricidade representou apenas $34,6 \mathrm{ktep}(0,5 \%)$ ou $402,3 \mathrm{GWh}$, coincidindo com igual valor relatado no calor de processo. Cabe ressaltar que estes valores citados na frase anterior apresentam uma grande divergência entre as planilhas do BEU (MME, 2005) versão sucinta, onde o total da energia final é 7.115,3 ktep, e versão ampliada onde o respectivo valor é 1.185,8 ktep, quando deveriam ser absolutamente iguais. A escolha dos dados da versão sucinta deve-se à verificação desta energia final nos dados históricos do BEN (MME, 2012), a qual coincide com a versão sucinta.

Dentre os processos de aquecimento direto, podem citados os processos de secagem (secador rotativo, secador túnel-esteira, spray dryer ${ }^{11}$, flash dryer $^{12}$ ) e calcinação de matérias primas de origem mineral como, por exemplo, citado por Nogueira e Rocha (2005), as indústrias de fertilizantes e de óxidos metálicos, além de outros processos como polimerização, redução de solventes e incineração.

O consumo de energia útil em eletricidade para o aquecimento direto foi de 23,9 ktep em 2004, considerada uma eficiência de 69\%. Embora relativamente pequeno, o potencial para conversão de eletrotermia para gás estaria principalmente na substituição de sistemas de aquecimento elétrico de reatores e geradores de ar quente pelos equipamentos correspondentes a gás.

Considerando o aquecimento direto de ar, com a utilização de queimadores de duto em substituição das resistências elétricas, uma das preocupações na área química para esta conversão seria a introdução de produtos da combustão no ar de secagem. Porém, a utilização direta de gás natural ou GLP pode garantir gases quentes diluídos em ar praticamente sem contaminação, por proporcionarem uma combustão isenta de fuligem e com teores de óxidos de enxofre desprezíveis, oriundos da queima das mercaptanas que conferem odor ao gás.

\footnotetext{
${ }^{11} \mathrm{O}$ termo spray dryer significa um tipo de secador onde o material a secar é projetado pulverizado.

${ }^{12} \mathrm{O}$ termo flash dryer é o modelo de secador onde o produto é alimentado parcialmente desidratado, sob a forma de lama finamente dividida.
} 
Uma das constatações desta afirmação é o fato que gases quentes gerados por queimadores de duto são utilizados para a secagem de produtos grau farmacêutico como, por exemplo, sorbitol. Os rendimentos dos citados processos de aquecimento direto do ar situam-se próximos de $100 \%$, pois tanto as resistências elétricas como os queimadores de duto são totalmente envolvidos pelo fluxo do ar. Assim, todo o calor liberado é obrigatoriamente destinado ao aquecimento do ar tanto nas opções de eletrotermia como a gás combustível.

Em alguns casos extremos, podem existir riscos envolvidos que não admitam a presença de chama aberta no interior do duto de ar, principalmente nos casos onde parte dos gases quentes retorna ao duto para recirculação, devido à existência de pós ou vapores inflamáveis apresentando uma concentração dentro ou próxima do campo de inflamabilidade. Nestes casos específicos, torna-se recomendável a utilização de fornalhas a gás com aquecimento indireto, onde o ar a aquecer atravessa a câmara de combustão através de feixes tubulares. Porém, o rendimento térmico da troca indireta é inferior ao rendimento com o queimador de duto, devido às perdas de calor dos gases na exaustão da fornalha, geralmente $60^{\circ}$ a $100^{\circ} \mathrm{C}$ acima da temperatura do ar quente, que se somam às perdas de calor através das superfícies da fornalha e, também, ao calor armazenado na estrutura da fornalha quando a operação seja descontínua. Em alguns casos de aquecimento de ar em baixas temperaturas, a utilização de óleos combustíveis competindo com gases combustíveis exigiria uma atenção especial quando houvesse a possibilidade da condensação de compostos ácidos, devido à presença de óxidos de enxofre nos produtos da combustão, exigindo a utilização de materiais mais nobres como aços austeníticos ou temperaturas de exaustão mais elevadas.

De acordo com Strapassom (2004), o potencial teórico estimado para substituição total da eletrotermia por gases combustíveis no setor de química pode ser considerado a $100 \%$ no panorama agressivo, baseando-se na experiência da indústria química argentina, indicado na Tabela 19, ou seja, 402,3 GWh ou 34,6 ktep com base no ano de 2004 (MME, 2005).

Tabela 19 - Substituição de eletrotermia em AD na indústria química

\begin{tabular}{|c|c|c|c|c|c|c|c|}
\hline \multicolumn{8}{|c|}{ INDÚSTRIA QUÍMICA - AQUECIMENTO DIRETO - BASE 2004} \\
\hline \multicolumn{5}{|c|}{ ENERGIA ELETRICA } & \multicolumn{3}{|c|}{ GASES COMBUSTIVEIS } \\
\hline & $\begin{array}{l}\text { COEF. DE } \\
\text { SUBSTIT. }\end{array}$ & $\begin{array}{c}\text { POTENCIAL } \\
\text { SUBSTIT. }\end{array}$ & $\begin{array}{l}\text { COEF. } \\
\text { EFIC. }\end{array}$ & $\begin{array}{c}\text { ENERGIA } \\
\text { SUBST. ÚTIL }\end{array}$ & $\begin{array}{l}\text { COEF. } \\
\text { EFIC. }\end{array}$ & ENE & A EQUI \\
\hline (ktep) & (\%) & (ktep) & $(\%)$ & (ktep) & (\%) & (ktep) & (unidade comercial) \\
\hline 34,6 & 100,0 & 34,6 & 69,0 & 23,9 & $\mathbf{5 2 , 0}$ & 45,9 & $52.172 \times 10^{3} \mathrm{~m}^{3}$ GN \\
\hline & & & & & & & 41.362 ton GLP \\
\hline
\end{tabular}

Fonte: elaboração própria, a partir de dados do BEU (MME, 2005) 


\subsubsection{Indústria de alimentos e bebidas (excluindo açúcar)}

O setor de alimentos e bebidas, incluindo o açúcar, passou a ser o maior consumidor de energia entre as diversas atividades industriais, totalizando $24.052 \mathrm{ktep}$ em 2012 (MME, 2013b), tendo superado o setor de ferro gusa e aço a partir de 2004. A exclusão do setor da indústria de açúcar na versão ampliada do BEU (MME, 2005) justifica-se pois totalizou, no ano de 2004, o valor de 13.106,3 ktep enquanto que o setor de alimentos e bebidas, excluído o setor de açúcar, atingiu apenas 4.492,8 ktep. Além disso, o setor de açúcar apresenta características peculiares quanto à energia final como o uso exclusivo de produtos da cana em calor de processo, não havendo praticamente uso de energia em aquecimento direto.

No setor de alimentos e bebidas, excluindo açúcar, o segmento de maior porte é o de carne e derivados, seguido do beneficiamento de café, chá e cereais, do processamento de óleos e gorduras e a produção de bebidas.

Cada segmento do setor de alimentos apresenta uma tendência tecnológica no uso de energéticos, a qual pode variar de acordo com o porte da indústria. As indústrias de grande porte, que produzem pães, bolos, biscoitos, bolachas, torradas e outras aplicações que envolvam cocção, preferem a utilização de fornos contínuos tipo túnel-esteira com aquecimento direto a gás natural, quando disponível, ou GLP. Nas demais indústrias existem um grande número de aplicações envolvendo, além da cocção, secagem, torrefação, esterilização e embalagem.

Já as panificações e pequenas indústrias dão preferência à eletrotermia em fornos descontínuos, devido à facilidade operacional e ao baixo índice de manutenção, apesar do custo elevado da energia elétrica que na maioria desses casos é fornecida em baixa tensão. Algumas dessas empresas ainda utilizam lenha e resíduos de madeira quando tais combustíveis estão localmente disponíveis a baixos custos, não existindo restrições ambientais.

Nas indústrias de bebidas, o aquecimento direto é aplicado na esterilização de embalagens (garrafas, potes e latas), secagem de matérias-primas e na aceleração do processo de fermentação, segundo Nogueira e Rocha (2005).

Os setores interligados com as atividades agrícolas costumam utilizar a biomassa como energético em caldeiras de geração de vapor e em secadores, onde a lenha ocupa posição de destaque no aquecimento direto com 807,0 ktep em 2004 (MME, 2005), representando 56,2\% da energia final de $1.434,9$ ktep. 
O uso de eletricidade para aquecimento direto, considerando a energia final utilizada em 2004 (MME, 2005), significou 189,1 ktep ou 2.198,8 GWh, conforme indica a Tabela 20.

Embora o potencial técnico para conversão de eletrotermia para gases combustíveis possa ser estimado em $100 \%$, o autor avalia que o potencial efetivo só possa atingir $35 \%$ em virtude de restrições de ordem prática devido ao porte de pequenas indústrias, limitações de espaço para instalar centrais de GLP quando gás natural não estiver disponível e limitações de ordem financeira para substituição ou conversão de equipamentos.

Tabela 20 - Substituição de eletrotermia em AD no setor de alimentos e bebidas, excluindo açúcar.

\begin{tabular}{|c|c|c|c|c|c|c|c|}
\hline \multicolumn{8}{|c|}{ IND. DE ALIMENTOS E BEBIDAS EXCL. AÇÚCAR - AQUECIMENTO DIRETO - BASE 2004} \\
\hline \multicolumn{5}{|c|}{ ENERGIA ELÉTRICA } & \multicolumn{3}{|c|}{ GASES COMBUSTÍVEIS } \\
\hline FINAL & $\begin{array}{l}\text { COEF. DE } \\
\text { SUBSTIT. }\end{array}$ & $\begin{array}{l}\text { POTENCIAL } \\
\text { SUBSTIT. }\end{array}$ & $\begin{array}{l}\text { COEF. } \\
\text { EFIC. }\end{array}$ & $\begin{array}{c}\text { ENERGIA } \\
\text { SUBST. ÚTIL }\end{array}$ & $\begin{array}{l}\text { COEF. } \\
\text { EFIC. }\end{array}$ & ENE & A EQUIVALENTE \\
\hline (ktep) & (\%) & (ktep) & $(\%)$ & (ktep) & (\%) & (ktep) & (unidade comercial) \\
\hline 189,1 & 35,0 & 66,2 & 65,0 & 43,0 & 52,0 & 82,7 & $94.013 \times 10^{3} \mathrm{~m}^{3} \mathrm{GN}$ \\
\hline & & & & & $\mathbf{5 2 , 0}$ & 82,7 & 74.533 ton GLP \\
\hline
\end{tabular}

Fonte: elaboração própria, a partir de dados do BEU (MME, 2005)

\subsubsection{Indústria de açúcar}

Este setor só utiliza dois vetores energéticos: produtos da cana e eletricidade, sendo que a energia elétrica final para o aquecimento direto representa apenas $2,1 \mathrm{ktep}$, ou seja, $0,016 \%$ da energia final total de 13.106,3 ktep em 2004 (MME, 2005). Considerando ainda que este setor possui a característica de geração própria a partir do bagaço da cana, o potencial para conversão de eletrotermia para gás não será considerado. Em consulta ao Eng. M.Sc. Marcelo Cesar Palmieri, que trabalhou no ramo, a única aplicação de eletrotermia encontrada é no ensacamento de açúcar (soldagem térmica dos sacos), onde desconhece-se a aplicação de gases combustíveis.

\subsubsection{Indústria têxtil}

O consumo total de energia da indústria têxtil em 2012 foi de 1.150 ktep (MME, 2013b), considerando todas as formas de energia.

O maior consumo de energéticos nos processos térmicos do setor têxtil não se faz por aquecimento direto e sim com a utilização de calor de processo, através de vapor e de fluidos 
térmicos. Nos últimos anos, alguns poucos processos têm migrado do calor de processo para aquecimento direto, como a substituição de vapor ou de fluidos térmicos nas ramas de secagem e de termofixação por produtos da combustão de gases, instalando-se diretamente um queimador a gás em cada campo (câmara) desses equipamentos.

Outras aplicações de aquecimento direto, pouco expressivas levando-se em conta o montante total de energia consumida neste setor, como a chamuscagem de tecidos já é realizada com gás combustível. Em passado longínquo, algumas chamuscadeiras usavam vapor de gasolina para esta aplicação, o qual foi sendo substituído naquela ocasião por GLP ou por gás manufaturado reformado.

Existem apenas algumas oportunidades isoladas, como o projeto que está sendo desenvolvido pela SCGás, referente à substituição de energia elétrica através do uso de queimadores radiantes a gás natural em máquinas de estampagem (ROCHA, 2010).

Outras aplicações de pouca expressão seriam as estufas para secagem de entretelas e de tecidos após banhos de engomagem, com resistências elétricas, prevalecendo a transferência de calor por radiação (infravermelho), muitas das quais já foram convertidas para queimadores infravermelhos a gás combustível.

O potencial para substituição de eletrotermia no aquecimento direto é muito baixo, tanto que no BEU (MME, 2005) nem consta consumo declarado neste segmento, certamente por ser inferior à unidade considerada de $10^{3}$ tep.

\subsubsection{Indústria de papel e celulose}

Apesar de ser uma atividade energointensiva, classificada em terceiro lugar entre os setores industriais tendo consumido, em 2012, $10.066 \mathrm{ktep}$ (MME, 2013b) sob todas as formas de energia, a indústria de papel e celulose pouco utiliza a modalidade do aquecimento direto, a qual representa menos de $1 \%$ da energia consumida em calor de processo.

Dentre as poucas aplicações do aquecimento direto neste setor encontram-se:

- o forno rotativo de calcinação, o qual justifica o consumo de óleos combustíveis indicado no BEU (MME, 2005), e cuja função é a conversão do carbonato de cálcio em óxido de cálcio, cuja tendência é a substituição do óleo combustível por gás natural; 
- e os queimadores radiantes para secagem de papel ou cura de revestimentos, justificando parte do consumo de GLP neste setor.

Com respeito ao uso da eletrotermia para aquecimento direto, o BEU (MME, 2005) indica valor nulo na ordem de grandeza de $10^{3}$ tep, portanto o potencial para conversão para gás combustível pode ser considerado desprezível, não tendo sido considerado.

\subsubsection{Indústria cerâmica}

O setor de cerâmica consumiu, no ano de 2012, o total de 4.803 ktep (MME, 2013) em todas as formas de energia. Observando-se o crescimento do consumo de energia total nos últimos anos, nota-se o reflexo do crescimento da indústria da construção civil neste setor. De acordo com o segmento considerado no setor cerâmico, existem tendências tecnológicas no uso de energéticos.

O segmento de cerâmica vermelha usa intensiva e tradicionalmente a lenha, fazendo com que seja a maior fonte de energia de todo o setor cerâmico, totalizando 1.611,2 ktep em 2004 (MME, 2005). De acordo com Henriques Jr. et al. (1993, p.17 e p.13), referindo-se à cerâmica vermelha, "o sistema térmico é responsável por cerca de $80-90 \%$ da energia total consumida no processo fabril" e alerta para o fato de que a lenha "[...] é utilizada de forma indiscriminada e ineficiente, o que pode determinar problemas ambientais associados ao desmatamento". O valor agregado em função de uma melhor qualidade, com a produção de cerâmica vermelha em fornos-túnel ${ }^{13}$ com gás natural ainda gera controvérsias, num mercado onde habitualmente o fator preço prevalece sobre a qualidade, levando-se em conta que o investimento nestes fornos torna-se inviável na medida em que acarretaria em custo mais elevado em energia. O uso de combustíveis nobres como gás natural e GLP na cerâmica vermelha, no Brasil, só é encontrado em casos excepcionais quando existe mercado para produtos de maior qualidade. Em países onde ocorrem abalos sísmicos existem exigências quanto à qualidade dos tijolos, como na Colômbia, onde até o transporte para as construções e seu manuseio é feito em pallets protegidos por filme plástico encolhível.

\footnotetext{
13 Fornos-túnel são tipos de fornos que se apresentam sob a forma geométrica de um túnel em linha reta, onde os produtos a serem queimados ou tratados são introduzidos por um lado do forno, trafegam em seu interior, e saem no lado oposto; o elemento de transporte no interior do forno pode ser vagonetas que trafegam sobre trilhos, esteiras transportadoras ou sequência de rolos giratórios.
} 
O segmento de cerâmica vermelha não utiliza a eletricidade como energético no aquecimento direto, e sim como força motriz na preparação de matérias-primas, moldagem de peças e ventiladores do ar de combustão, além das aplicações convencionais de iluminação e equipamentos de escritório.

No setor de revestimentos cerâmicos, a utilização de gases combustíveis em fornos-túnel é tradicional nas grandes indústrias. No passado existia o processo de biqueima, onde na primeira queima as peças eram produzidas sem acabamento, recebiam a decoração e eram novamente queimadas. Este processo passou a ser monoqueima, no qual as duas etapas se transformaram em apenas uma, reduzindo assim o consumo específico de combustível e aumentando a produtividade. Este segmento utilizava GLP, o que rapidamente viabilizou a instalação de gasodutos de GN nos polos ceramistas devido à atratividade despertada pela concentração geográfica de elevados consumos. Além disso, estes fornos operam continuamente (24 horas por dia), com sua potência total dividida em um grande número de queimadores, gerando um perfil de vazão estável nas redes de gás natural, o que é ideal para as concessionárias. Segundo Lackner, Winter e Agarwal (2010), os consumos específicos médios para fornos-túnel de revestimentos cerâmicos são de $58 \mathrm{~m}^{3}$ de gás natural ou $46 \mathrm{~kg}$ de GLP por tonelada de produto, onde as temperaturas máximas atingem valores na faixa de $1.050^{\circ}$ a $1.250^{\circ} \mathrm{C}$.

Outro importante segmento é o da indústria cerâmica para uso doméstico (louça de mesa) e louças sanitárias, onde as grandes empresas também utilizam fornos-túnel. Segundo MMESGM (2009a), os consumos específicos variam de 153 a $388 \mathrm{~m}^{3}$ de gás natural por tonelada de louça sanitária.

Comparando-se os consumos específicos de gás combustível entre revestimentos cerâmicos e louça sanitária, notam-se diferenças muito significativas, porém justificáveis pelas características de transmissão de calor em artigos de geometrias tão diversas. Enquanto os revestimentos possuem uma elevada área específica de troca de calor, a louça sanitária apresenta espessuras mais elevadas e partes ocas internas que dificultam a troca de calor, além da carga térmica absorvida pelas vagonetas que transportam as peças através do forno e suas mobílias.

Os fornos-túnel são equipamentos de alta produção e sua concepção faz com que haja uma boa conservação da energia, pois o calor contido nos produtos da combustão nas zonas de alta temperatura trafega em contracorrente com o fluxo da carga, preaquecendo-a e secando-a. $\mathrm{O}$ uso de gases combustíveis, praticamente isentos de enxofre, possibilita o aproveitamento do 
calor desses produtos da combustão até temperaturas pouco acima do meio ambiente, podendo ser utilizados em secadores externos aos fornos-túnel.

Existem ainda outros segmentos na área cerâmica como materiais refratários e cerâmica técnica. A indústria de materiais refratários utiliza como energéticos, em seus fornos e secadores, o gás natural e o óleo combustível. Além dos fornos-túnel, existem também os fornos descontínuos, onde os refratários são produzidos em bateladas. Apesar da grande diversidade de produtos neste segmento, a referência de consumo de combustíveis para os produtos que necessitam passar pela queima em fornos situa-se na faixa de 600 a 800 Mcal por tonelada (MME-SGM, 2009b), correspondendo a consumos específicos de 68 a $91 \mathrm{~m}^{3}$ de gás natural ou 63 a $83 \mathrm{~kg}$ de óleo combustível por tonelada de refratário.

Segundo o BEU (MME, 2005), os consumos de energia final de GN e GLP em aquecimento direto foram, respectivamente, 767,4 ktep e 100,6 ktep, correspondendo aos valores de energia útil de 422,0 ktep e 55,3 ktep, conforme os rendimentos térmicos de ambos os gases estimados em $55 \%$.

Analisando-se os consumos específicos do setor cerâmico, que compreende uma ampla gama de valores, mostra que as análises feitas pelo BEU (MME, 2005), considerando toda a indústria cerâmica em um único setor, conduzem a resultados de pouca utilidade prática quanto aos rendimentos térmicos assumidos.

O uso da eletricidade no aquecimento direto se concentra em pequenos fornos, do tipo intermitente, e em fornos tipo túnel de pequenas dimensões, no âmbito das pequenas empresas, cuja energia final informada pelo BEU (MME, 2005) foi de apenas 16,8 ktep ou 195,3 GWh em 2004, conforme indica a Tabela 21, que pode ser considerado como o potencial teórico de conversão para gás combustível.

Tabela 21 - Substituição de eletrotermia em AD na indústria cerâmica

\begin{tabular}{|c|c|c|c|c|c|c|c|}
\hline \multicolumn{8}{|c|}{ INDÚSTRIA CERÂMICA - AQUECIMENTO DIRETO - BASE 2004} \\
\hline \multicolumn{5}{|c|}{ ENERGIA ELÉTRICA } & \multicolumn{3}{|c|}{ GASES COMBUSTÍVEIS } \\
\hline $\begin{array}{l}\text { FINAL } \\
\text { (ktep) }\end{array}$ & $\begin{array}{c}\text { COEF. DE } \\
\text { SUBSTIT. } \\
(\%)\end{array}$ & $\begin{array}{c}\text { POTENCIAL } \\
\text { SUBSTIT. } \\
\text { (ktep) }\end{array}$ & $\begin{array}{c}\text { COEF. } \\
\text { EFIC. } \\
(\%)\end{array}$ & $\begin{array}{c}\text { ENERGIA } \\
\text { SUBST. ÚTIL } \\
\text { (ktep) }\end{array}$ & $\begin{array}{c}\text { COEF. } \\
\text { EFIC. } \\
(\%)\end{array}$ & $\begin{array}{r}\text { ENE } \\
\text { (ktep) }\end{array}$ & $\begin{array}{l}\text { A EQUIVALENTE } \\
\text { (unidade comercial) }\end{array}$ \\
\hline 16,8 & $\mathbf{2 0 , 0}$ & 3,4 & $\mathbf{5 8 , 0}$ & 1,9 & $\begin{array}{l}55,0 \\
55,0\end{array}$ & $\begin{array}{l}3,5 \\
3,5\end{array}$ & $\begin{array}{l}4.026 \times 10^{3} \mathrm{~m}^{3} \mathrm{GN} \\
3.192 \text { ton GLP }\end{array}$ \\
\hline
\end{tabular}

Fonte: elaboração própria, a partir de dados do BEU (MME, 2005) 
A energia útil correspondente foi de 9,7 ktep, considerando-se o rendimento térmico de 58\%. Estes fornos dedicam-se geralmente a queimar peças produzidas em pequenas séries ou produtos artesanais como brindes, louça personalizada e pequenas séries de peças para revestimento. A conversão da eletrotermia para gases combustíveis, em termos de custos dos energéticos, pode ser favorável a estas indústrias, geralmente de pequeno porte, devido a este segmento comprar energia elétrica em baixa tensão. Baseando-se em visitas realizadas pelo autor em 2008 nas indústrias cerâmicas de pequeno porte no município de Porto Ferreira SP, onde a maioria dos equipamentos são fornos elétricos descontínuos, a estimativa para conversão neste segmento não seria superior a 20\%, conforme aplicado na Tabela 21.

Por outro lado as pequenas indústrias, muitas vezes, têm receio de substituir um processo conhecido (elétrico) por outro inovador (a gás), apesar da atratividade despertada pela redução de custos. Outros fatores que também dificultam a tomada de decisão para essa conversão seriam os seguintes: dificuldade para investir, seja com recursos próprios ou externos; falta de mão de obra interna especializada para a manutenção dos novos sistemas a gás.

\subsubsection{Outros setores da indústria}

Esta classificação engloba todos os setores não especificamente citados anteriormente, tornando qualquer tentativa de análise, através de resultados tão genéricos, uma missão impossível. Mesmo em alguns setores bem definidos, como analisado anteriormente, torna-se difícil uma análise apurada a partir de números singelos, devido à grande variedade de processos, equipamentos e matérias-primas.

Alguns setores que devem ter sido enquadrados como outros setores da indústria são: indústria de vidros e cristais, indústria dos produtos do fumo, indústria de preparação de couro e fabricação de seus artefatos, indústria de produtos da madeira, indústria de produtos de borracha e materiais plásticos, indústria mecânica, indústria de material elétrico e de comunicações, indústria de material de transporte e indústria gráfica.

A Tabela 22, elaborada a partir do BEU (MME, 2005), informa qual seria o potencial teórico para a conversão da eletrotermia no aquecimento direto. Em setores tão variados valeria a pena aplicar a premissa de ordem prática citada pelo Eng. Paul Poulallion no curso Gestão em Energia, ministrado em 2007 pelo Instituto de Eletrotécnica e Energia - USP, a partir de sua 
grande experiência no assunto, de que cerca de $30 \%$ dos processos industriais de eletrotermia, em média, poderiam ser convertidos para gases combustíveis.

Tabela 22 - Substituição de eletrotermia em AD em outros setores da indústria

\begin{tabular}{|c|c|c|c|c|c|c|c|}
\hline \multicolumn{8}{|c|}{ OUTROS SETORES DA INDÚSTRIA - AQUECIMENTO DIRETO - BASE 2004} \\
\hline \multicolumn{5}{|c|}{ ENERGIA ELÉTRICA } & \multicolumn{3}{|c|}{ GASES COMBUSTÍVEIS } \\
\hline & $\begin{array}{l}\text { COEF. DE } \\
\text { SUBSTIT. }\end{array}$ & $\begin{array}{l}\text { POTENCIAL } \\
\text { SUBSTIT. }\end{array}$ & $\begin{array}{l}\text { COEF. } \\
\text { EFIC. }\end{array}$ & $\begin{array}{c}\text { ENERGIA } \\
\text { SUBST. ÚTIL }\end{array}$ & $\begin{array}{l}\text { COEF. } \\
\text { EFIC. }\end{array}$ & ENE & EQUIVALENTE \\
\hline (ktep) & (\%) & (ktep) & (\%) & (ktep) & (\%) & (ktep) & (unidade comercial) \\
\hline 569,6 & 30,0 & $\Rightarrow 170,9$ & $\mathbf{5 5 , 0}$ & 94,0 & $\begin{array}{l}\mathbf{5 2 , 0} \\
52,0\end{array}$ & $\begin{array}{l}180,7 \\
180,7\end{array}$ & $\begin{array}{l}205.385 \times 10^{3} \mathrm{~m}^{3} \mathrm{GN} \\
162.827 \text { ton GLP }\end{array}$ \\
\hline
\end{tabular}

Fonte: elaboração própria, a partir de dados do BEU (MME, 2005) e Paul Poulallion

\subsection{Potencial total para substituição de eletrotermia em aquecimento direto}

Esta consolidação levou em conta os potenciais estimados para o aquecimento direto nos setores das indústrias, calculados com base no BEU (MME,2005).

Com o intuito de atualizar os valores para o ano de 2012, foram estimados fatores para o crescimento dos setores iguais à razão entre os consumos totais de energia elétrica nos anos 2012 e 2004, conforme o BEN 2013 - base 2012 (MME, 2013b), Tabela 2.28 - Eletricidade.

A Tabela 23 apresenta a consolidação dos valores calculados nas Tabelas 14, 15, 16, 17, 18, 19, 20, 21 e 22, totalizando os valores para os usos finais em aquecimento direto. O potencial tecnológico, que corresponde a um panorama agressivo, mesmo não incluindo a indústria de ferro-gusa e aço, apresentou a possibilidade de se atingir o valor de 15.409,5 GWh na conversão para gases combustíveis, estimativa esta projetada para o ano de 2012.

Os consumos finais indicados pelo BEN 2013, base 2012 (MME,2013b) foram:

- Consumo nos setores industriais: $\quad 209.622 \mathrm{GWh} / \mathrm{ano}$

- Consumo total: $\quad 498.399 \mathrm{GWh} / \mathrm{ano}$

Assim, o potencial tecnológico para substituição da eletrotermia, considerando apenas as aplicações em aquecimento direto, significa 7,4\% do consumo industrial e 3,1\% do consumo total de energia elétrica. 
Tabela 23 - Potencial de substituição da eletrotermia em aquecimento direto

\begin{tabular}{|c|c|c|c|c|c|}
\hline \multirow[t]{2}{*}{ SETORES INDUSTRIAIS } & \multicolumn{2}{|c|}{$\begin{array}{l}\text { ENERGIA FINAL } \\
\text { BASE } 2004\end{array}$} & \multirow{2}{*}{$\begin{array}{c}\text { CRESCIMENTO } \\
\text { DO SETOR } \\
(2012 \text { / 2004) }\end{array}$} & \multicolumn{2}{|c|}{$\begin{array}{l}\text { ENERGIA FINAL } \\
\text { BASE } 2012\end{array}$} \\
\hline & (ktep) & (GWh) & & (ktep) & (GWh) \\
\hline Cimento & $\mathbf{0 , 0}$ & $\mathbf{0 , 0}$ & 2,034 & $\mathbf{0 , 0}$ & $\mathbf{0 , 0}$ \\
\hline Ferro gusa e aço & n.a. & n.a. & n.a. & n.a. & n.a. \\
\hline Ferro-ligas & 127,1 & $1.477,9$ & 1,011 & 128,5 & $1.494,2$ \\
\hline Mineração & 30,0 & 348,8 & 1,200 & 36,0 & 418,6 \\
\hline Pelotização & 1,5 & 17,4 & 1,200 & 1,8 & 20,9 \\
\hline Alumínio & 444,6 & $5.169,8$ & 1,116 & 496,2 & $5.769,5$ \\
\hline Outros produtos metálicos & 284,4 & $3.307,0$ & 1,116 & 317,4 & $3.690,6$ \\
\hline Química & 34,6 & 402,3 & 1,116 & 38,6 & 449,0 \\
\hline Alimentos e bebidas excl. açúcar & 66,2 & 769,8 & 1,419 & 93,9 & $1.092,3$ \\
\hline Açúcar & $\mathbf{0 , 0}$ & 0,0 & 1,419 & 0,0 & 0,0 \\
\hline Têxtil & $\mathbf{0 , 0}$ & 0,0 & 1,015 & 0,0 & $\mathbf{0 , 0}$ \\
\hline Papel e celulose & 0,0 & 0,0 & 1,387 & 0,0 & 0,0 \\
\hline Cerâmica & 3,4 & 39,5 & 1,368 & 4,7 & 54,1 \\
\hline Outros setores & 170,9 & $1.987,2$ & 1,218 & 208,2 & $2.420,4$ \\
\hline TOTAIS & $1.162,7$ & $13.519,8$ & & $1.325,2$ & $15.409,5$ \\
\hline
\end{tabular}

Obs.: n.a. - não avaliado

Fonte: elaboração própria

A Tabela 24 consolida os potenciais calculados nas Tabelas 14, 15, 16, 17, 18, 19, 20, 21 e 22 para energia final em GLP e GN, expressos nas unidades de comercialização, necessários à referida substituição da eletrotermia, com valores projetados para 2012.

Os potenciais para gases combustíveis neste setor poderiam atingir:

- $\quad$ 1.667.138.000 $\mathrm{m}^{3}$ de GN por ano ou 4.567.500 $\mathrm{m}^{3}$ por dia;

- ou 1.321.696 ton de GLP por ano ou 3.621 ton GLP por dia.

Apenas este potencial tecnológico para o consumo de GLP já superia o superávit da oferta, previsto a partir de 2016-2017, mas certamente a parcela mais significativa desse consumo ficaria com o gás natural, restando ao GLP principalmente as indústrias mais afastadas das redes de distribuição e onde o preço fosse viável. 
Tabela 24 - Potencial para gases combustíveis substitutos em aquecimento direto

\begin{tabular}{|c|c|c|c|c|c|}
\hline \multicolumn{6}{|c|}{ CONSOLIDAÇÃO DO POTENCIAL - GASES COMBUSTÍVEIS SUBSTITUTOS EM AQUECIMENTO DIRETO } \\
\hline \multirow[t]{2}{*}{ SETORES INDUSTRIAIS } & \multicolumn{2}{|c|}{$\begin{array}{l}\text { ENERGIA FINAL } \\
\text { BASE } 2004\end{array}$} & \multirow{2}{*}{$\begin{array}{c}\text { CRESCIMENTO } \\
\text { DO SETOR } \\
(2012 / 2004)\end{array}$} & \multicolumn{2}{|c|}{$\begin{array}{c}\text { ENERGIA FINAL } \\
\text { BASE } 2012\end{array}$} \\
\hline & $\left(10^{3} \mathrm{~m}^{3} \mathrm{GN}\right)$ & (ton GLP) & & $\left(10^{3} \mathrm{~m}^{3} \mathrm{GN}\right)$ & (ton GLP) \\
\hline Cimento & $\mathbf{0}$ & $\mathbf{0}$ & 2,034 & $\mathbf{0}$ & $\mathbf{0}$ \\
\hline Ferro gusa e aço & n.a. & n.a. & n.a. & n.a. & n.a. \\
\hline Ferro-ligas & 154.797 & 122.722 & 1,011 & 156.500 & 124.072 \\
\hline Mineração & 36.526 & 28.958 & 1,200 & 43.831 & 34.750 \\
\hline Pelotização & 2.131 & 1.689 & 1,200 & 2.557 & 2.027 \\
\hline Alumínio & 555.750 & 440.595 & 1,116 & 620.217 & 491.704 \\
\hline Outros produtos metálicos & 355.500 & 281.838 & 1,116 & 396.738 & 314.531 \\
\hline Química & 52.172 & 41.362 & 1,116 & 58.224 & 46.160 \\
\hline Alimentos e bebidas excl. açúcar & 94.013 & 74.533 & 1,419 & 133.404 & 105.762 \\
\hline Açúcar & 0 & 0 & 1,419 & $\mathbf{0}$ & 0 \\
\hline Têxtil & $\mathbf{0}$ & 0 & 1,015 & $\mathbf{0}$ & $\mathbf{0}$ \\
\hline Papel e celulose & $\mathbf{0}$ & 0 & 1,387 & $\mathbf{0}$ & $\mathbf{0}$ \\
\hline Cerâmica & 4.026 & 3.192 & 1,368 & $\mathbf{5 . 5 0 7}$ & 4.366 \\
\hline Outros setores & 205.385 & 162.827 & 1,218 & 250.159 & 198.323 \\
\hline TOTAIS & 1.460 .300 & 1.157 .716 & & 1.667 .138 & 1.321 .696 \\
\hline
\end{tabular}

Obs.: n.a. - não avaliado

Fonte: elaboração própria

\subsection{Conclusões do capítulo 5}

A partir dos valores calculados, pode-se concluir que o potencial tecnológico para substituição de energia elétrica, considerando apenas o aquecimento direto, significaria $3,1 \%$ do total da energia elétrica consumida no Brasil no ano de 2014. Mais diante, este potencial será adicionado aos valores estimados para o calor de processo no capítulo 6. 


\section{ALTERNATIVAS PARA A SUBSTITUIÇÃO DA ELETROTERMIA NO CALOR DE PROCESSO}

O objetivo deste capítulo é calcular os potenciais para substituição da eletrotermia por gases combustíveis no calor de processo para cada setor industrial, consolidar os resultados e estimar a projeção destes potenciais para o ano de 2012. O algoritmo de cálculo para a elaboração das Tabelas 26, 27, 28, 29, 30, 31 e 32 será o mesmo utilizado em aquecimento direto, apresentado na Figura 24.

Assim como realizado no aquecimento direto, a abordagem no calor de processo consiste na análise dos principais setores industriais que constam das planilhas do BEU (MME, 2005) versão ampliada, a saber: Cimento, Ferro-Gusa e Aço, Ferro-Ligas, Mineração, Pelotização, Alumínio, Outros Metálicos (não ferrosos exceto alumínio), Química, Alimentos e Bebidas (excluindo Açúcar), Açúcar, Têxtil, Papel e Celulose, Cerâmica e Outros Setores Industriais. A padronização de equipamentos neste grupo de aplicações de energia torna a análise da conversão de eletrotermia para gás combustível bem menos complexa do que no aquecimento direto, permitindo considerar o potencial desta conversão na totalidade dos casos em todos os setores que apresentem consumo desta energia final.

O BEU (MME, 2005) definiu quatro setores de aplicação para classificar os equipamentos segundo faixas de potências equivalentes à capacidade de geração de vapor, apesar de nem sempre tratar-se de vapor, visto que estes setores abrangem outros fluidos como água e óleos térmicos. A definição destes setores de aplicação tomou como filosofia básica a premissa de que os rendimentos energéticos são significativamente influenciados, em tese, pelo porte dos equipamentos: maior o porte, mais elevado o rendimento e vice-versa. Tal premissa pode ser justificada por três motivos principais:

- a relação área-volume, onde equipamentos de maior porte apresentam menor área específica, significando perdas de calor para o meio ambiente, através das superfícies externas, relativamente inferiores comparando-se com equipamentos de menor porte;

- a relação massa-volume, onde equipamentos de maior capacidade são relativamente mais leves nas suas estruturas aquecidas como casco, tubos e isolamento térmico, o significa menor consumo específico dos energéticos para o aquecimento destas estruturas; 
- e a relação custo-benefício no investimento em equipamentos periféricos para conservação de energia, como preaquecedores de ar e água, mais atrativa em equipamentos de maior porte.

Porém existem ainda outros fatores que também influenciam o rendimento energético, como as condições de projeto e de manutenção dos equipamentos.

As condições de projeto podem influir negativamente no rendimento energético dos equipamentos, na medida em que se trate de projetos realizados em ocasiões quando o custo dos combustíveis era baixo, como antes da década dos anos 70, ou em locais onde havia abundância de combustível residual que em certas ocasiões necessitava ser incinerado, como ocorreu na indústria sucroalcooleira. Mesmo na atualidade, ainda é possível encontrar equipamentos relativamente novos cujos projetos sofreram restrições quanto ao investimento em medidas de conservação de energia, como a inexistência de sistemas de recuperação de calor dos produtos da combustão para o preaquecimento de ar de combustão e/ou preaquecimento de água, retorno de condensado, isolamento térmico e queimadores de maior eficiência (modulantes, baixo índice de excesso de ar de combustão), de forma que seus rendimentos térmicos deixam a desejar.

As condições de manutenção também podem influenciar no rendimento energético, como a limpeza das superfícies de troca térmica, o monitoramento da combustão com a regulagem de queimadores e a integridade do isolamento térmico na geração e distribuição do fluido térmico; no caso de sistemas de vapor, cabe acrescentar ainda a redução do rendimento devido aos vazamentos de vapor e à inadequada purga excessiva de lodos.

Com base na filosofia do porte dos equipamentos, os setores de aplicação foram assim definidos pelo BEU (MME, 2005):

- Setores A:

Trata-se de equipamentos de pequeno porte, geralmente para aquecimento de água, utilizados pelos setores Residencial, Comercial e Público. Podem ser aquecedores elétricos de passagem (torneiras, chuveiros e aquecedor central) e aquecedores elétricos de acumulação, com potências que não costumam ultrapassar $11 \mathrm{~kW}$. E, também, aquecedores de passagem e de acumulação a gás natural e GLP, com potências de até $80.000 \mathrm{kcal} / \mathrm{h}(93 \mathrm{~kW})$. A Resolução $\mathrm{n}^{\circ} 456$ de 29/11/2000 da Agência Nacional de Energia Elétrica - ANEEL estabelece em seu Art. $6^{\circ}$ inciso I que 
apenas cargas instaladas até $75 \mathrm{~kW}$ inclusive terá seu fornecimento em tensão secundária de distribuição (ANEEL, 2000). O inciso II do referido artigo estabelece que o fornecimento para cargas instaladas acima de $75 \mathrm{~kW}$ e inferiores ou iguais a $2.500 \mathrm{~kW}$ será realizado pela tensão primária de distribuição inferior a $69 \mathrm{kV}$. Portanto, para residências e pequenos comércios evita-se que a cargas instaladas totais ultrapassem o limite de $75 \mathrm{~kW}$, limitando de certa forma o uso de equipamentos elétricos cujas potências contribuam para tal, de forma que o fornecimento possa ser feito na tensão secundária para reduzir os custos da instalação. E, com respeito à influência nos resultados auferidos, pelo fato de que neste setor possam ser utilizados equipamentos de maior porte, o BEU (MME, 2005, p.30) afirma que "há alguns poucos casos de centrais de aquecimento de água em residências e no setor comercial, que tem pouco significado estatístico.”

\section{- Setores B}

Nos setores classificados com a letra B foram incluídos os ramos de atividades que, tradicionalmente, utilizam equipamentos de pequeno porte, definidos pelo BEU (MME, 2005) como aqueles cujas potências térmicas sejam equivalentes à geração inferior ou igual a 5 toneladas de vapor por hora. Contudo, a potência correspondente a esta geração de vapor varia de acordo com uma série de características como a pressão do vapor produzido (saturado), a pressão e a temperatura do vapor (superaquecido), a temperatura da água no reservatório que alimenta a caldeira (função da temperatura da água no retorno do condensado, da temperatura da água de reposição, das proporções entre essas duas fontes e das perdas de calor no reservatório) e a eficiência da caldeira. Assim, para estimar a potência térmica considerada para este Setor, de forma a se enquadrar os aquecedores de água e de fluidos térmicos, foram assumidas as seguintes hipóteses tomando-se por base as situações mais comumente encontradas nas indústrias:

- caldeira de vapor saturado seco na pressão de $980 \mathrm{kPa}\left(10 \mathrm{kgf} / \mathrm{cm}^{2}\right)$;

- água de alimentação na temperatura de $60^{\circ} \mathrm{C}$, considerando retorno parcial de condensado;

- rendimentos energéticos considerados para o ano de 2004 (MME, 2005):

. caldeira elétrica: $\quad 0,940$; 
- caldeira a combustíveis líquidos e gasosos: $\quad 0,720$;

. caldeira a combustíveis sólidos: 0,620.

Desta forma, as potências térmicas aproximadas das caldeiras, para a produção de 5 toneladas de vapor por hora, seriam:

- caldeira elétrica:

- caldeira a combustíveis líquidos e gasosos:

- caldeira a combustíveis sólidos:
$3,2 \mathrm{Gcal} / \mathrm{h}=3,7 \mathrm{MW}$;

$4,2 \mathrm{Gcah} / \mathrm{h}$

$4,9 \mathrm{Gcal} / \mathrm{h}$.

Portanto, as potências térmicas a serem consideradas para os aquecedores de água e de fluidos térmicos nos Setores B poderiam atingir valores máximos de acordo com as potências térmicas calculadas no parágrafo anterior e com os respectivos energéticos.

Os ramos de atividades considerados neste Setor foram: Transporte Ferroviário, Agropecuário, de Ferro Ligas, Cerâmica, Cimento e Outros Setores Industriais.

No setor Agropecuário, o calor de processo restringe-se basicamente ao uso de vapor saturado para atividades como secagem de produtos agrícolas (sementes, grãos e seus farelos, folhas, flores e frutos), mitigação de pragas (principalmente frutos para exportação) e climatização de ambientes em climas frios como aviários. Porém o uso do calor de processo no setor Agropecuário, sempre que tecnicamente possível e na maioria dos casos, é suplantado pelo aquecimento direto devido aos rendimentos mais elevados associados aos investimentos mais baixos, exigindo ainda uma manutenção menos sofisticada em áreas afastadas dos grandes centros urbanos.

Os setores de Ferro Ligas, Cerâmica e Cimento se caracterizam pelo uso do Aquecimento Direto. As aplicações do Calor de Processo, quando existentes, se resumem no uso de vapor saturado para o preaquecimento dos óleos combustíveis residuais nos tanques de armazenagem e nos sistemas de traçagem das tubulações, possibilitando seu bombeio, e nos tanques de trabalho onde é feito o aquecimento final para atingir a viscosidade adequada a uma boa atomização nos queimadores. Embora pouco comum nos dias de hoje, o vapor pode também ser utilizado como meio de atomização nos queimadores de óleos residuais que foram projetados para tal. 
E, a classificação de Outros Setores Industriais abrange um grande número de empresas, inclusive algumas citadas na letra $\mathrm{D}$, mas de porte discreto como pequenas indústrias químicas, têxteis e de alimentos e bebidas. Podem ser ainda relacionadas outros ramos de atividades como indústrias de borracha, de derivados da madeira e curtumes.

- Setores C

Os Setores C correspondem às atividades de Transporte Hidroviário, Ferro Gusa e Aço, Mineração e Pelotização, Alumínio e Outros Metais Não Ferrosos. O BEU (MME, 2005) atribuiu aos Setores C o uso de equipamentos de porte médio, cujas potências sejam equivalentes à geração de vapor superior a 5 e até 40 toneladas por hora. De forma análoga aos Setores B, os Setores $\mathrm{C}$ referentes às atividades industriais relatadas no parágrafo anterior utilizam tipicamente o Aquecimento Direto, sendo o Calor de Processo utilizado na área de utilidades quando necessário, notadamente nas aplicações de aquecimento de óleos combustíveis residuais como já descrito.

\section{- Setores D}

Nos setores D, correspondentes aos setores Energético, Químico, de Alimentos e Bebidas, Têxtil e Papel e Celulose, o panorama muda completamente com relação aos setores anteriores. Trata-se de setores onde o Calor de Processo passa a ser uma das fontes mais importantes de energia, ocupando frequentemente a posição principal. Os equipamentos são de grande porte, basicamente caldeiras a vapor do tipo aquatubular, com capacidades superiores a 40 toneladas por hora. Nestes setores também são encontrados sistemas de geração de energia elétrica através de turbinas com vapor superaquecido, sendo o vapor saturado obtido como subproduto (cogeração).

\subsection{Rendimentos energéticos em CP}

O BEU (MME, 2005), em seu capítulo 4.4, apresenta um sumário dos rendimentos energéticos para o Calor de Processo para cada grupo de setores de atividades e seus insumos energéticos, considerando as edições anteriores referentes aos anos de 1984 e 1994, de forma a mostrar a evolução até esta última edição com os dados de 2004. 
A Tabela 25 mostra a citada evolução dos rendimentos e, também, os rendimentos de referência que considerou o estado da arte dos equipamentos comercializados naquela ocasião para servir aos propósitos do benchmarking. Quanto aos rendimentos energéticos informados nesta tabela, cabe entender que se referem a dados médios de cada setor. Isso porque existem variações dos rendimentos devidas não somente à concepção do equipamento e seus dispositivos para conservação de energia, como também do estado de conservação e das temperaturas de trabalho dos fluidos.

Tabela 25 - Rendimentos por setores de aplicação em calor de processo

\begin{tabular}{lccccc}
\hline \multirow{2}{*}{ ENERGÉTICOS } & SETORES DE & \multicolumn{4}{c}{ RENDIMENTOS ENERGÉTICOS / ANO } \\
\cline { 3 - 6 } & APLICAÇÃO & 1984 & 1994 & 2004 & Referência \\
\hline Eletricidade & $\mathrm{B}$ & 0,900 & 0,930 & 0,940 & 0,950 \\
Combustíveis gasosos & $\mathrm{B}$ & 0,600 & 0,680 & 0,720 & 0,750 \\
\hline Eletricidade & $\mathrm{C}$ & 0,930 & 0,940 & 0,950 & 0,960 \\
Combustíveis gasosos & $\mathrm{C}$ & 0,700 & 0,750 & 0,780 & 0,800 \\
\hline Eletricidade & $\mathrm{D}$ & 0,950 & 0,960 & 0,970 & 0,980 \\
Combustíveis gasosos & $\mathrm{D}$ & 0,850 & 0,870 & 0,880 & 0,900 \\
\hline
\end{tabular}

Fonte: elaboração própria a partir de Processamento FDTE apud BEU (MME, 2005).

Cabe observar que os rendimentos energéticos para a eletricidade no Setor de Aplicação "A" não foram considerados por estar fora do âmbito desta tese. $O$ escopo deste trabalho considerou apenas as aplicações industriais, as quais estão referidas nos setores B, C e D e os seguintes energéticos: eletricidade e combustíveis gasosos.

\subsection{Potenciais de substituição da eletrotermia em CP por setor industrial}

Neste item são estimados os potenciais de substituição da eletrotermia por gases combustíveis, utilizando as eficiências do BEU (2005) para cada setor industrial.

\subsubsection{Indústria de cimento}

O setor de cimento pouco utiliza calor de processo, ou seja, apenas $11,5 \%$ do valor correspondente à energia consumida em aquecimento direto no ano de 2004, considerando a energia final (MME, 2005). 
E o consumo de energia elétrica para calor de processo foi indicado com nulo na ordem de grandeza de $10^{3}$ tep, não havendo potencial para conversão da eletrotermia para gás combustível, segundo apurado pelo BEU (MME, 2005).

\subsubsection{Indústria de ferro gusa e aço}

O consumo de energia elétrica referente ao calor de processo, em 2004, correspondeu a 27.700 tep (MME, 2005), ou seja, 322,1 GWh, que representa o potencial para conversão de eletrotermia para gás combustível.

A Tabela 26 apresenta o potencial para conversão e a energia final equivalente em toneladas equivalentes de petróleo e em gases combustíveis em suas unidades de comercialização, considerando o GN e o GLP.

Tabela 26 - Substituição de eletrotermia em CP na indústria de ferro gusa e aço

\begin{tabular}{|c|c|c|c|c|c|c|c|}
\hline \multicolumn{8}{|c|}{ INDÚSTRIA DE FERRO GUSA E AÇO - CALOR DE PROCESSO - BASE 2004} \\
\hline \multicolumn{5}{|c|}{ ENERGIA ELÉTRICA } & \multicolumn{3}{|c|}{ GASES COMBUSTÍVEIS } \\
\hline $\begin{array}{l}\text { FINAL } \\
\text { (ktep) }\end{array}$ & $\begin{array}{l}\text { COEF. DE } \\
\text { SUBSTIT. } \\
\text { (\%) }\end{array}$ & $\begin{array}{l}\text { POTENCIAL } \\
\text { SUBSTIT. } \\
\text { (ktep) }\end{array}$ & $\begin{array}{l}\text { COEF. } \\
\text { EFIC. } \\
(\%)\end{array}$ & $\begin{array}{l}\text { ENERGIA } \\
\text { SUB. ÚTIL } \\
\text { (ktep) }\end{array}$ & $\begin{array}{l}\text { COEF. } \\
\text { EFIC. } \\
\text { (\%) }\end{array}$ & $\begin{array}{l}\text { ENEI } \\
\text { (ktep) }\end{array}$ & $\begin{array}{l}\text { A EQUIVALENTE } \\
\text { (unidade comercial) }\end{array}$ \\
\hline 27,7 & 100,0 & 27,7 & 94,0 & 26,0 & $\begin{array}{l}72,0 \\
72,0\end{array}$ & $\begin{array}{l}36,2 \\
36,2\end{array}$ & $\begin{array}{l}41.095 \times 10^{3} \mathrm{~m}^{3} \mathrm{GN} \\
32.580 \text { ton GLP }\end{array}$ \\
\hline
\end{tabular}

Fonte: elaboração própria, a partir de dados do BEU (MME, 2005)

\subsubsection{Indústria de ferro-ligas}

O setor de ferro-ligas não apresentou nenhum consumo de eletricidade em energia final na modalidade calor de processo no BEU (MME, 2005).

\subsubsection{Indústria de mineração}

O setor de indústria de mineração apresentou um consumo discreto de eletricidade em energia final para calor de processo, correspondente a 11.800 tep (MME, 2005) ou 137,2 GWh. A Tabela 27 apresenta o potencial para substituição da eletrotermia para gases combustíveis, considerando os coeficientes de eficiência energética. 
Tabela 27 - Substituição de eletrotermia em CP na indústria de mineração

\begin{tabular}{|c|c|c|c|c|c|c|c|}
\hline \multicolumn{8}{|c|}{ INDÚSTRIA DE MINERAÇÃO - CALOR DE PROCESSO - BASE 2004} \\
\hline \multicolumn{5}{|c|}{ ENERGIA ELÉTRICA } & \multicolumn{3}{|c|}{ GASES COMBUSTÍVEIS } \\
\hline & $\begin{array}{l}\text { COEF. DE } \\
\text { SUBSTIT. }\end{array}$ & $\begin{array}{l}\text { POTENCIAL } \\
\text { SUBSTIT. }\end{array}$ & $\begin{array}{l}\text { COEF. } \\
\text { EFIC. }\end{array}$ & $\begin{array}{l}\text { ENERGIA } \\
\text { SUB. ÚTIL }\end{array}$ & $\begin{array}{l}\text { COEF. } \\
\text { EFIC. }\end{array}$ & ENE & A EQI \\
\hline (ktep) & (\%) & (ktep) & $(\%)$ & (ktep) & (\%) & (ktep) & (unidade comercial) \\
\hline 11,8 & 100,0 & 11,8 & $\mathbf{9 5 , 0}$ & 11,2 & $\mathbf{7 8 , 0}$ & 14,4 & $16.332 \times 10^{3} \mathrm{~m}^{3} \mathrm{GN}$ \\
\hline & & & & & 78,0 & 14,4 & 12.948 ton GLP \\
\hline
\end{tabular}

Fonte: elaboração própria, a partir de dados do BEU (MME, 2005)

\subsubsection{Indústria de pelotização}

O setor de indústria de pelotização não apresentou consumo de energia elétrica na ordem de grandeza $10^{3}$ tep, segundo o BEU (MME, 2005).

\subsubsection{Indústria de alumínio}

Este setor de indústria é um intenso usuário de aquecimento direto e eletroquímica, mas a utilização de energia elétrica em calor de processo é muito discreta, totalizando em 2004 (MME, 2005) apenas 2.100 tep ou 24,4 GWh. A Tabela 28 apresenta a correspondência entre o potencial de conversão de eletrotermia e a energia final equivalente em GN e GLP.

Tabela 28 - Substituição de eletrotermia em CP na indústria de alumínio

\begin{tabular}{|c|c|c|c|c|c|c|c|}
\hline \multicolumn{8}{|c|}{ INDÚSTRIA DE ALUMÍNIO - CALOR DE PROCESSO - BASE 2004} \\
\hline \multicolumn{5}{|c|}{ ENERGIA ELÉTRICA } & \multicolumn{3}{|c|}{ GASES COMBUSTÍVEIS } \\
\hline $\begin{array}{l}\text { FINAL } \\
\text { (ktep) }\end{array}$ & $\begin{array}{c}\text { COEF. DE } \\
\text { SUBSTIT. } \\
(\%)\end{array}$ & $\begin{array}{c}\text { POTENCIAL } \\
\text { SUBSTIT. } \\
\text { (ktep) }\end{array}$ & $\begin{array}{l}\text { COEF. } \\
\text { EFIC. } \\
(\%)\end{array}$ & $\begin{array}{c}\text { ENERGIA } \\
\text { SUBST. ÚTIL } \\
\text { (ktep) }\end{array}$ & $\begin{array}{c}\text { COEF. } \\
\text { EFIC. } \\
(\%)\end{array}$ & $\begin{array}{r}\text { ENE } \\
\text { (ktep) }\end{array}$ & $\begin{array}{l}\text { A EQUIVALENTE } \\
\text { (unidade comercial) }\end{array}$ \\
\hline 2,1 & 100,0 & 2,1 & 95,0 & 2,0 & $\begin{array}{l}78,0 \\
78,0\end{array}$ & 2,6 & $\begin{array}{l}2.906 \times 10^{3} \mathrm{~m}^{3} \mathrm{GN} \\
2.304 \text { ton GLP }\end{array}$ \\
\hline
\end{tabular}

Fonte: elaboração própria, a partir de dados do BEU (MME, 2005)

\subsubsection{Indústria de outros produtos metálicos}

O setor de outros produtos metálicos não ferrosos e excluindo o alumínio não apresenta consumo de energia elétrica em calor de processo na ordem de grandeza utilizada pelo BEU (2005), não havendo potencial para substituição da eletrotermia. 


\subsubsection{Indústria química}

O setor de indústria química caracteriza-se pela intensiva utilização de calor de processo, principalmente com o uso do vapor saturado através de trocadores de calor, reatores e outros equipamentos de processo. As propriedades termodinâmicas do vapor saturado, como seu elevado calor latente cedido na condensação e sua relação biunívoca entre temperatura e pressão facilitam sua aplicação e controle nos processos químicos.

A intensa demanda de vapor neste segmento significa um interessante potencial para CHP, através de vapor superaquecido gerando energia elétrica e tendo o vapor saturado como subproduto.

A Figura 31 mostra a evolução do consumo de energéticos, onde se destaca a progressiva substituição do óleo combustível por gás natural.

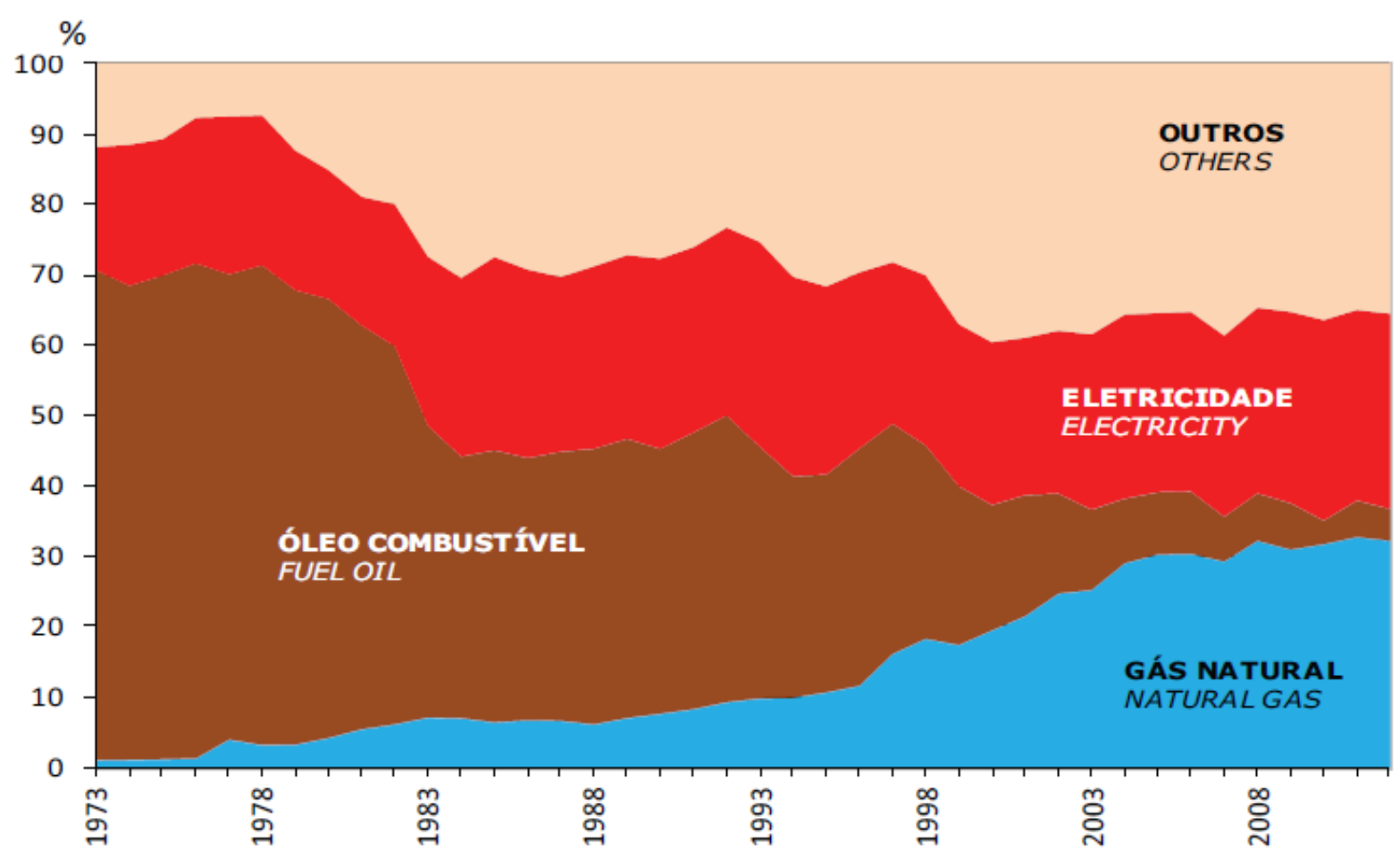

Figura 31 - Consumo de energéticos na indústria química

Fonte: BEN (MME, 2013)

O calor de processo totalizou o consumo de energia final de 4.646,7 ktep no ano de 2004 (MME, 2005), representando 65,3\% do consumo total de energia deste ano (7.115,3 ktep). A participação do gás natural no calor de processo em foi expressiva, 1.974,7 ktep, a dos 
derivados do petróleo 2.539,2 ktep, enquanto a da eletricidade foi apenas 34,6 ktep ou 402,3 GWh no ano de 2004 (MME, 2005), que seria o potencial considerado para conversão a gás. A Tabela 29 indica a energia final correspondente em GLP e GN, após a conversão da eletrotermia, levando em conta os coeficientes de eficiência energética para as aplicações de energia elétrica e gases combustíveis. O valor da energia final de 34,6 ktep foi considerado da versão não ampliada das planilhas do BEU, pois existe uma não conformidade entre ambas as informações que deveriam ser iguais. $\mathrm{O}$ valor escolhido está mais coerente com os consumos de energia apresentados na sequência histórica.

Tabela 29 - Substituição de eletrotermia em CP na indústria química

\begin{tabular}{|c|c|c|c|c|c|c|c|}
\hline \multicolumn{8}{|c|}{ INDÚSTRIA QUÍMICA - CALOR DE PROCESSO - BASE 2004} \\
\hline \multicolumn{5}{|c|}{ ENERGIA ELÉTRICA } & \multicolumn{3}{|c|}{ GASES COMBUSTÍVEIS } \\
\hline & $\begin{array}{l}\text { COEF. DE } \\
\text { SUBSTIT. }\end{array}$ & $\begin{array}{l}\text { POTENCIAL } \\
\text { SUBSTIT. }\end{array}$ & $\begin{array}{l}\text { COEF. } \\
\text { EFIC. }\end{array}$ & $\begin{array}{l}\text { ENERGIA } \\
\text { SUBST. ÚTIL }\end{array}$ & $\begin{array}{l}\text { COEF. } \\
\text { EFIC. }\end{array}$ & ENE & A EQUIVALENTE \\
\hline (ktep) & (\%) & & & (ktep) & (\%) & (ktep) & (unidade comercial) \\
\hline 34,6 & 100,0 & 34,6 & 97,0 & 33,6 & $\begin{array}{l}88,0 \\
88,0\end{array}$ & $\begin{array}{l}38,1 \\
38,1\end{array}$ & $\begin{array}{l}43.339 \times 10^{3} \mathrm{~m}^{3} \mathrm{GN} \\
34.359 \text { ton GLP }\end{array}$ \\
\hline
\end{tabular}

Fonte: elaboração própria, a partir de dados do BEU (2005)

\subsubsection{Indústria de alimentos e bebidas excluindo açúcar}

O setor de alimentos e bebidas (excluindo açúcar) engloba uma infinidade de processos e equipamentos, utiliza intensivamente calor de processo, totalizando a energia final de 1.944,7 ktep segundo o BEU (2005), base 2004.

Os setores de alimentos e bebidas interligados com as atividades agrícolas costumam utilizar a biomassa como energético em caldeiras de geração de vapor e em secadores de uma forma direta, como queima de lenha e resíduos sólidos, ou indireta sob a forma de biogás geralmente associado a um combustível tradicional. Considerando o total da energia final utilizada em calor de processo no ano de 2004, 965,1 ktep referem-se à lenha, significando 49,6\% (BEU, 2005).

O setor de bebidas praticamente utiliza calor de processo, notadamente vapor saturado, para preparação de xaropes para refrigerantes, aquecimento do mosto para fermentação e, também, lavagem de embalagens.

O uso de eletricidade para calor de processo em 2004, considerando a energia final (BEU 2005), foi de 196,6 ktep ou 2.286,0 GWh, que é o potencial para conversão. A Tabela 30 
mostra a conversão de eletrotermia para GN e GLP, quantificando a energia final equivalente para estes gases combustíveis.

Tabela 30 - Substituição de eletrotermia em CP na indústria de alimentos e bebidas excluindo açúcar

\begin{tabular}{|c|c|c|c|c|c|c|c|}
\hline \multicolumn{8}{|c|}{ IND. DE ALIMENTOS E BEBIDAS EXCL. AÇÚCAR - CALOR DE PROCESSO - BASE 2004} \\
\hline \multicolumn{5}{|c|}{ ENERGIA ELÉTRICA } & \multicolumn{3}{|c|}{ GASES COMBUSTÍVEIS } \\
\hline & $\begin{array}{l}\text { COEF. DE } \\
\text { SUBSTIT. }\end{array}$ & $\begin{array}{l}\text { POTENCIAL } \\
\text { SUBSTIT. }\end{array}$ & $\begin{array}{l}\text { COEF. } \\
\text { EFIC. }\end{array}$ & $\begin{array}{c}\text { ENERGIA } \\
\text { SUBST. ÚTIL }\end{array}$ & $\begin{array}{l}\text { COEF. } \\
\text { EFIC. }\end{array}$ & ENE & A EQUIVAL \\
\hline (ktep) & (\%) & (ktep) & (\%) & (ktep) & (\%) & (ktep) & (unidade comercial) \\
\hline 196,6 & 100,0 & 196,6 & 97,0 & 190,7 & 88,0 & 216,7 & $246.258 \times 10^{3} \mathrm{~m}^{3} \mathrm{GN}$ \\
\hline & & & & & $\mathbf{8 8 , 0}$ & $\mathbf{2 1 6 , 7}$ & 195.231 ton GLP \\
\hline
\end{tabular}

Fonte: elaboração própria, a partir de dados do BEU (MME, 2005)

\subsubsection{Indústria de açúcar}

O setor da indústria de açúcar utiliza exclusivamente o bagaço de cana como combustível para o calor de processo, totalizando 12.782,5 ktep em 2004 (MME, 2005). Portanto não há utilização da eletricidade para o calor de processo, pelo menos na ordem de grandeza considerada pelo BEU.

\subsubsection{Indústria têxtil}

A energia total consumida pelo setor têxtil foi de 1.150,0 ktep no ano de 2012 (MME, 2013), cujos valores vêm se mantendo no mesmo patamar desde 2004 pois, certamente, todo o acréscimo de demanda do mercado vem sendo suprido por importações. O setor têxtil utiliza intensivamente o calor de processo, sob as formas de vapor saturado e fluidos térmicos, totalizando o consumo de energia final de 471,4 ktep em 2004 (MME, 2005). Deste total, destacam-se o gás natural (279,5 ktep), os óleos combustíveis (106,9 ktep) e a lenha (76,7 ktep).

No setor da indústria têxtil, o BEU (MME, 2005) não indica nenhum consumo de energia elétrica para o calor de processo, portanto considera-se nulo o potencial de conversão de eletrotermia para gás combustível. 


\subsubsection{Indústria de papel e celulose}

A indústria de papel e celulose é o terceiro setor da área industrial que mais consome energia totalizando, em 2012, 10.066 ktep (MME, 2013b). Observando-se a série histórica publicada no BEN (MME, 2013b), o consumo total de energia neste setor vem crescendo significativamente nos últimos 10 anos, pois no ano de 2002 haviam sido consumidas apenas $6.591,0$ ktep.

Neste setor, que utiliza tradicionalmente o calor de processo, o vapor gerado é na realidade um subproduto, pois se trata de caldeiras de recuperação de produtos químicos oriundos do processo de digestão da madeira $\left(\mathrm{Na}_{2} \mathrm{CO}_{3}\right.$ - carbonato de sódio ou barrilha e $\mathrm{Na}_{2} \mathrm{~S}$ - sulfeto de sódio), a partir da queima do licor negro concentrado, operando como um reator químico e, também, queimando a matéria orgânica presente no licor, aproveitando seu poder calorífico e evitando seu descarte (SENAI-FIEP, 2011). Essas caldeiras de recuperação produzem vapor superaquecido para geração de energia elétrica, com a cogeração de vapor saturado, sendo este mercado dominado por dois principais fabricantes de acordo com Pedro (2011): Metso $(54 \%)$ e CBC (33\%).

O uso de eletricidade para calor de processo no ano de 2004 (MME, 2005), correspondendo a 36,4 ktep ou 423.332 MWh em energia final, é relativamente baixo comparando-se com a energia total de 6.061,6 ktep despendida nesta modalidade de utilização. Mas ainda é um potencial interessante para conversão da eletrotermia, conforme indica a Tabela 31.

Tabela 31 - Substituição de eletrotermia em CP na indústria de papel e celulose

\begin{tabular}{|c|c|c|c|c|c|c|c|}
\hline \multicolumn{8}{|c|}{ IND. DE PAPEL E CELULOSE - CALOR DE PROCESSO - BASE 2004} \\
\hline \multicolumn{5}{|c|}{ ENERGIA ELÉTRICA } & \multicolumn{3}{|c|}{ GASES COMBUSTÍVEIS } \\
\hline $\begin{array}{r}\text { FINAL } \\
\text { (ktep) }\end{array}$ & $\begin{array}{c}\text { COEF. DE } \\
\text { SUBSTIT. } \\
(\%)\end{array}$ & $\begin{array}{c}\text { POTENCIAL } \\
\text { SUBSTIT. } \\
\text { (ktep) }\end{array}$ & $\begin{array}{c}\text { COEF. } \\
\text { EFIC. } \\
(\%)\end{array}$ & $\begin{array}{c}\text { ENERGIA } \\
\text { SUBST. ÚTIL } \\
\text { (ktep) }\end{array}$ & $\begin{array}{c}\text { COEF. } \\
\text { EFIC. } \\
(\%)\end{array}$ & $\begin{array}{r}\text { ENE } \\
\text { (ktep) }\end{array}$ & $\begin{array}{l}\text { A EQUIVALENTE } \\
\text { (unidade comercial) }\end{array}$ \\
\hline 36,4 & 100,0 & 36,4 & 97,0 & 35,3 & $\begin{array}{l}88,0 \\
88,0\end{array}$ & $\begin{array}{l}40,1 \\
40,1\end{array}$ & $\begin{array}{l}45.594 \times 10^{3} \mathrm{~m}^{3} \mathrm{GN} \\
\text { 36.147 ton GLP }\end{array}$ \\
\hline
\end{tabular}

Fonte: elaboração própria, a partir de dados do BEU (MME, 2005)

\subsubsection{Indústria cerâmica}

O setor de cerâmica, conforme visto em aquecimento direto, é um grande consumidor de energia. Porém, tratando-se de calor de processo, seu consumo de energéticos é discreto, totalizando em 2004 (MME, 2005) apenas 116,4 ktep ou seja, 4,1\% do consumo em 
aquecimento direto do mesmo ano. Os energéticos consumidos no calor de processo naquele ano foram óleo combustível, GLP e óleo diesel, não havendo consumo de energia elétrica na ordem de grandeza da unidade $\left(10^{3}\right.$ tep).

Portanto não há potencial detectável para conversão de eletrotermia para gás combustível em calor de processo.

\subsubsection{Outros setores da indústria}

Esta classificação, englobando todos os setores não especificamente citados anteriormente, possibilita ainda assim algumas análises devido à padronização dos equipamentos restritos a caldeiras e aquecedores sob a ótica da conversão da eletrotermia para gases combustíveis.

Como exemplo de outros setores, encontra-se o setor de fabricação de artigos de borracha o qual não se enquadra no setor de Química, afirmação baseada na classificação preconizada pelo CNAE - Classificação Nacional de Atividades Econômicas. A produção de elastômeros, que enquadra todos os tipos de borrachas, sim se enquadra no setor Químico (divisão 20). Mas as indústrias que seguem essa cadeia produtiva, confeccionando os artigos de borracha, pertencem à outra classificação (divisão 22), subdividida em três classes: fabricação de pneumáticos e câmaras de ar; reforma de pneumáticos usados; e fabricação dos demais artefatos de borracha.

A produção de artigos de borracha utiliza intensivamente o calor de processo, principalmente vapor saturado e fluidos térmicos, e aquecimento direto, basicamente com a aplicação de resistências elétricas. O uso da eletrotermia está presente em muitas aplicações, mas o enfoque mais significativo concentra-se no aquecimento direto de moldes e no aquecimento de fluidos térmicos, este último compartilhado com óleos e gases combustíveis.

A título de ilustração, cabe citar o trabalho de conversão de eletrotermia para GLP realizado em uma indústria de borracha no município de Monte Alto - SP, no ano de 2011. Os principais produtos são perfis de borracha extrudados para a indústria automobilística, os quais passam por um processo de vulcanização através de fornos contínuos tipo túnel, aquecidos por fluido térmico, originalmente gerado apenas por aquecedores elétricos do tipo acumulação. Cada forno possuía seu aquecedor elétrico com a potência nominal de $60 \mathrm{~kW}$ e sua bomba de recirculação.

Esta indústria está situada em local afastado do centro da cidade, em zona considerada rural, cujo fornecimento de energia elétrica se encontrava no limite máximo para o atendimento da 
demanda contratada por falta de capacidade da rede de distribuição. Houve, então, necessidade da ampliação da fábrica com a instalação de mais dois fornos-túnel, o que exigiria o aumento da demanda contratada em $60 \mathrm{~kW}$ por forno, totalizando $120 \mathrm{~kW}$. Não existindo interesse por parte da distribuidora local na ampliação da capacidade da rede externa, todos os custos correriam por conta da indústria.

Após criteriosa análise econômica, a opção eleita direcionou para a instalação de aquecedores de fluido térmico a GLP, pois a empresa já dispunha desse gás combustível para outras aplicações.

Foram então dimensionados dois aquecedores do tipo instantâneo, com instalação mural e potência nominal de $90.000 \mathrm{kcal} / \mathrm{h}$ cada um (Figura 32), de forma que pudessem trabalhar independentemente com cada túnel.

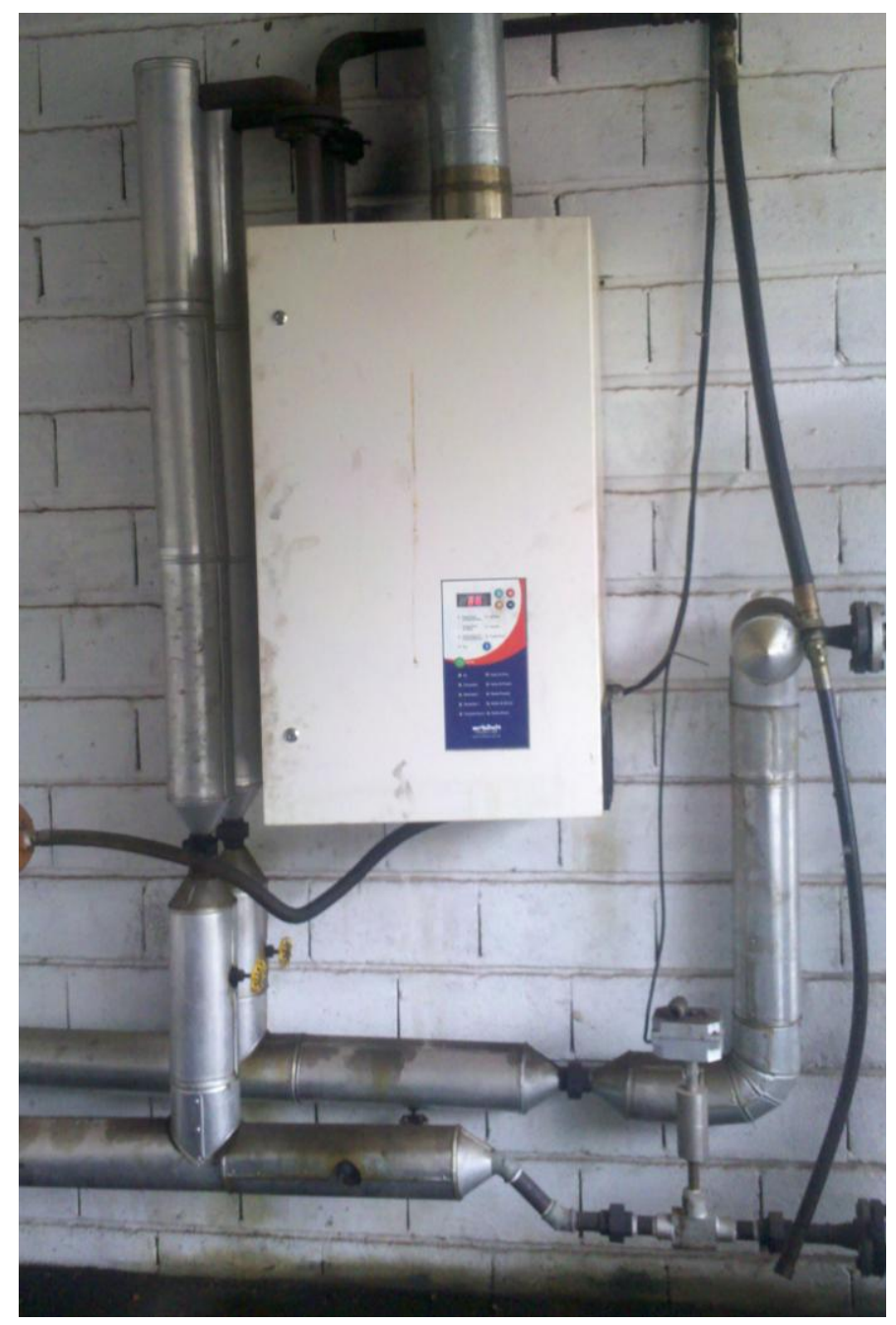

Figura 32 - Aquecedor instantâneo de óleo térmico a GLP

Fonte: cortesia da Cia. Ultragaz S.A. 
A escolha de aquecedor instantâneo do tipo mural proporciona uma elevada eficiência térmica, pois inexiste reservatório do fluido térmico, no qual ocorrem dois tipos de perda de calor: perdas superficiais para a atmosfera; e perdas inerciais quando a demanda é intermitente, ou seja, a indústria não opera nos 3 turnos. Porém, a inexistência do referido reservatório, que funciona como um pulmão de inércia térmica nos aquecedores de acumulação, exige que o sistema de aquecimento instantâneo tenha um controle de temperatura muito preciso e sensível. Neste caso e em outros similares, a precisão da potência do queimador só é possível de ser obtida com gerenciamento eletrônico em função das temperaturas de entrada e de saída do fluido térmico, onde o controle da potência possa atender às demandas térmicas com tempos de resposta inferiores a um segundo.

O coeficiente de eficiência energética média de 72\% indicada pelo BEU (MME, 2005) para GN e GLP, neste setor, poderia ser reestimado na faixa de 80 a $85 \%$ neste caso particular. Considerando conservativamente o valor de $80 \%$, a potência útil de cada aquecedor seria de $72.000 \mathrm{kcal} / \mathrm{h}$, suplantando a potência nominal dos tradicionais aquecedores elétricos de 60 $\mathrm{kW}$, cuja potência útil seria 56,4 kW (eficiência de 94\%, segundo MME, 2005) ou 48.504 $\mathrm{kcal} / \mathrm{h}$. Este acréscimo da potência útil em $48,4 \%$ e a menor inércia térmica do volume de óleo térmico contido no sistema possibilitaram a redução do tempo de preaquecimento dos fornos nas partidas diárias a frio, pois a fábrica não operava nos três turnos, e possibilitou ainda o aumento de produtividade desses dois fornos.

Segundo o BEU (MME, 2005), o consumo de energia elétrica em calor de processo em outros setores da indústria no ano de 2004 foi de 44,7 ktep ou 519,8 GWh, que é o potencial de conversão para gases combustíveis. A Tabela 32 mostra o correspondente consumo em GN e GLP, levando em conta os respectivos rendimentos.

Tabela 32 - Substituição de eletrotermia em CP nos outros setores da indústria

\begin{tabular}{|c|c|c|c|c|c|c|c|}
\hline \multicolumn{8}{|c|}{ OUTROS SETORES DA INDÚSTRIA - CALOR DE PROCESSO - BASE 2004} \\
\hline \multicolumn{5}{|c|}{ ENERGIA ELÉTRICA } & \multicolumn{3}{|c|}{ GASES COMBUSTIIVEIS } \\
\hline & $\begin{array}{l}\text { COEF. DE } \\
\text { SUBSTIT. }\end{array}$ & $\begin{array}{l}\text { POTENCIAL } \\
\text { SUBSTIT. }\end{array}$ & $\begin{array}{l}\text { COEF. } \\
\text { EFIC. }\end{array}$ & $\begin{array}{c}\text { ENERGIA } \\
\text { SUBST. ÚTIL }\end{array}$ & $\begin{array}{l}\text { COEF. } \\
\text { EFIC. }\end{array}$ & ENE & A EQUIVALENTE \\
\hline (ktep) & (\%) & (ktep) & $(\%)$ & (ktep) & (\%) & (ktep) & (unidade comercial) \\
\hline 44,7 & 100,0 & 44,7 & 94,0 & 42,0 & $\begin{array}{l}72,0 \\
72,0\end{array}$ & $\begin{array}{l}58,4 \\
58,4\end{array}$ & $\begin{array}{l}66.316 \times 10^{3} \mathrm{~m}^{3} \mathrm{GN} \\
52.575 \text { ton GLP }\end{array}$ \\
\hline
\end{tabular}

Fonte: elaboração própria, a partir de dados do BEU (MME, 2005) 


\subsection{Potencial total para substituição de eletrotermia em calor de processo}

Esta consolidação levou em conta os potenciais estimados para o calor de processo nos setores das indústrias, calculados com base no BEU (MME, 2005), referentes ao ano de 2004. Com o intuito de atualizar os valores para o ano de 2012, foram estimados fatores para o crescimento dos setores iguais à razão entre os consumos totais de energia elétrica nos anos 2012 e 2004, conforme BEN (MME, 2013b), Tabela 2.28 - Eletricidade, de forma análoga à filosofia adotada para o aquecimento direto.

A Tabela 33 apresenta a consolidação a partir dos valores calculados nas Tabelas 26, 27, 28, $29,30,31$ e 32 , totalizando os valores para os usos finais em calor de processo.

Tabela 33 - Potencial de substituição da eletrotermia em calor de processo

\begin{tabular}{|c|c|c|c|c|c|}
\hline \multicolumn{6}{|c|}{ CONSOLIDAÇÃO DO POTENCIAL - SUBSTITUIÇÃO DA ELETROTERMIA EM CALOR DE PROCESSO } \\
\hline \multirow[t]{2}{*}{ SETORES INDUSTRIAIS } & \multicolumn{2}{|c|}{$\begin{array}{c}\text { ENERGIA FINAL } \\
\text { BASE } 2004\end{array}$} & \multirow{2}{*}{$\begin{array}{c}\text { CRESCIMENTO } \\
\text { DO SETOR } \\
(2012 / 2004)\end{array}$} & \multicolumn{2}{|c|}{$\begin{array}{c}\text { ENERGIA FINAL } \\
\text { BASE } 2012\end{array}$} \\
\hline & (ktep) & $(\mathbf{G W h})$ & & (ktep) & $(\mathbf{G W h})$ \\
\hline Cimento & 0,0 & $\mathbf{0 , 0}$ & 2,034 & $\mathbf{0 , 0}$ & 0,0 \\
\hline Ferro gusa e aço & 27,7 & 322,1 & 1,167 & 32,3 & 375,9 \\
\hline Ferro-ligas & $\mathbf{0 , 0}$ & $\mathbf{0 , 0}$ & 1,011 & $\mathbf{0 , 0}$ & $\mathbf{0 , 0}$ \\
\hline Mineração & 11,8 & 137,2 & 1,200 & 14,2 & 164,7 \\
\hline Pelotização & 0,0 & 0,0 & 1,200 & 0,0 & 0,0 \\
\hline Alumínio & 2,1 & 24,4 & 1,116 & 2,3 & 27,3 \\
\hline Outros produtos metálicos & 0,0 & 0,0 & 1,116 & 0,0 & $\mathbf{0 , 0}$ \\
\hline Química & 34,6 & 402,3 & 1,116 & 38,6 & 449,0 \\
\hline Alimentos e bebidas excl. açúcar & 196,6 & $2.286,0$ & 1,419 & 279,0 & $3.243,9$ \\
\hline Açúcar & $\mathbf{0 , 0}$ & $\mathbf{0 , 0}$ & 1,419 & $\mathbf{0 , 0}$ & $\mathbf{0 , 0}$ \\
\hline Têxtil & 0,0 & $\mathbf{0 , 0}$ & 1,015 & $\mathbf{0 , 0}$ & $\mathbf{0 , 0}$ \\
\hline Papel e celulose & 36,4 & 423,3 & 1,387 & $\mathbf{5 0 , 5}$ & 587,1 \\
\hline Cerâmica & 0,0 & 0,0 & 1,368 & $\mathbf{0 , 0}$ & $\mathbf{0 , 0}$ \\
\hline Outros setores & 44,7 & 519,8 & 1,218 & 54,4 & 633,1 \\
\hline TOTAIS & 353,9 & $4.115,1$ & & 471,3 & $5.480,8$ \\
\hline
\end{tabular}

Fonte: elaboração própria

A Tabela 34 consolida o potencial para os gases combustíveis substitutos em calor de processo, também calculados a partir das Tabelas 26, 27, 28. 29, 30, 31 e 32. 
Tabela 34 - Potencial para gases combustíveis substitutos em calor de processo

\begin{tabular}{|c|c|c|c|c|c|}
\hline \multicolumn{6}{|c|}{ CONSOLIDAÇÃO DO POTENCIAL - GASES COMBUSTÍVEIS SUBSTITUTOS EM CALOR DE PROCESSO } \\
\hline \multirow[t]{2}{*}{ SETORES INDUSTRIAIS } & \multicolumn{2}{|c|}{$\begin{array}{c}\text { ENERGIA FINAL } \\
\text { BASE } 2004\end{array}$} & \multirow{2}{*}{$\begin{array}{c}\text { CRESCIMENTO } \\
\text { DO SETOR } \\
(2012 \text { / 2004) }\end{array}$} & \multicolumn{2}{|c|}{$\begin{array}{c}\text { ENERGIA FINAL } \\
\text { BASE } 2012\end{array}$} \\
\hline & $\left(10^{3} \mathrm{~m}^{3} \mathrm{GN}\right)$ & (ton GLP) & & $\left(10^{3} \mathrm{~m}^{3} \mathrm{GN}\right)$ & (ton GLP) \\
\hline Cimento & $\mathbf{0}$ & $\mathbf{0}$ & 2,034 & $\mathbf{0}$ & $\mathbf{0}$ \\
\hline Ferro gusa e aço & 41.095 & 32.580 & 1,167 & 47.958 & 38.021 \\
\hline Ferro-ligas & $\mathbf{0}$ & $\mathbf{0}$ & 1,011 & $\mathbf{0}$ & $\mathbf{0}$ \\
\hline Mineração & 16.332 & 12.948 & 1,200 & 19.598 & 15.538 \\
\hline Pelotização & $\mathbf{0}$ & $\mathbf{0}$ & 1,200 & $\mathbf{0}$ & $\mathbf{0}$ \\
\hline Alumínio & 2.906 & 2.304 & 1,116 & 3.243 & 2.571 \\
\hline Outros produtos metálicos & $\mathbf{0}$ & $\mathbf{0}$ & 1,116 & $\mathbf{0}$ & $\mathbf{0}$ \\
\hline Química & 43.339 & 34.359 & 1,116 & 48.366 & 38.345 \\
\hline Alimentos e bebidas excl. açúcar & 246.258 & 195.231 & 1,419 & 349.440 & 277.033 \\
\hline Açúcar & $\mathbf{0}$ & $\mathbf{0}$ & 1,419 & $\mathbf{0}$ & $\mathbf{0}$ \\
\hline Têxtil & $\mathbf{0}$ & $\mathbf{0}$ & 1,015 & $\mathbf{0}$ & $\mathbf{0}$ \\
\hline Papel e celulose & 45.594 & 36.147 & 1,387 & 63.239 & 50.136 \\
\hline Cerâmica & $\mathbf{0}$ & $\mathbf{0}$ & 1,368 & $\mathbf{0}$ & $\mathbf{0}$ \\
\hline Outros setores & 66.316 & 52.575 & 1,218 & 80.773 & 64.036 \\
\hline TOTAIS & 461.840 & 366.144 & & 612.618 & 485.679 \\
\hline
\end{tabular}

Fonte: elaboração própria

\subsection{Conclusões do capítulo 6}

O potencial tecnológico para substituição da eletrotermia para gás combustível em calor de processo, apesar de todos os casos serem possíveis de conversão, é bem inferior ao potencial do aquecimento direto tomando-se por base o ano de 2012: 5.480,8 GWh / ano. O potencial total, consolidando também o aquecimento direto, está indicado no capítulo 7. 


\section{REDUÇÃo NO CONSUMO DE ENERGIA PRIMÁRIA PELA SUBSTITUIÇÃO DE ELETROTERMIA}

Este capítulo tem por objetivo final estimar a redução do consumo de energia primária considerando a substituição da eletrotermia por gás natural e GLP. Para isso é necessário consolidar as estimativas realizadas anteriormente em aquecimento direto (capítulo 5) e calor de processo (capítulo 6), calcular as eficiências das termelétricas e determinar os fatores de conversão de energia final para energia primária em dois panoramas distintos:

I. Nas cadeias da energia elétrica.

II. Nas cadeias dos gases combustíveis.

\subsection{Consolidação dos potenciais estimados}

A Tabela 35 consolida os potenciais estimados para substituição da eletrotermia por GLP e GN, considerando as respectivas energias finais, de acordo com os valores obtidos nas Tabelas 23, 24, 33 e 34.

Tabela 35 - Potencial para as energias finais

\begin{tabular}{cccccc}
\hline CATEGORIA & \multicolumn{4}{c}{ POTENCIAL PARA AS ENERGIAS FINAIS - BASE 2012 } \\
DE & \multicolumn{2}{c}{ Eletrotermia substituída } & \multicolumn{3}{c}{ Gás combustível substituto } \\
USO FINAL & ktep & GWh & ktep & $10^{3} \mathrm{~m}^{3} \mathrm{GN}$ & ton GLP \\
\hline Aquecimento direto & $1.325,2$ & $15.409,5$ & $1.467,1$ & 1.667 .138 & 1.321 .696 \\
Calor de processo & 471,3 & $5.480,8$ & 539,1 & 612.618 & 485.679 \\
\hline TOTAL & $1.796,5$ & $20.890,3$ & $2.006,2$ & 2.279 .756 & 1.807 .375 \\
\hline
\end{tabular}

Fonte: elaboração própria

Considerações da parte da energia elétrica:

- o potencial consolidado para a substituição da eletrotermia por gases combustíveis em aquecimento direto e calor de processo como sendo 20.890,3 GWh, estimado com base no ano de 2012; 
- o consumo final total de energia elétrica nos setores industriais informado pelo BEN 2013, referente ao ano base 2012 (MME, 2013b), de 209.622 GWh;

- o consumo final total de energia elétrica em todos os setores, informado pelo BEN 2013, referente ao ano base 2012 (MME, 2013b), de 498.399 GWh.

Conclui-se então que o potencial consolidado para substituição da eletrotermia corresponde a 9,97\% da energia elétrica consumida nos setores industriais e a 4,19\% da energia elétrica consumida em todos os setores, ambas as percentagens referidas ao ano de 2012. Assim, a economia de energia elétrica anual de 20.890,3 GWh significaria um valor ainda um pouco superior ao crescimento da demanda nacional dos últimos anos, visto que os acréscimos de consumo de eletricidade total de 2010 para 2011 foi 16.269 GWh, e de 2011 para 2012 correspondeu a 17.430 GWh (MME, 2013b).

Considerações da parte dos gases combustíveis:

- O potencial para a demanda de gás natural na substituição da eletrotermia foi consolidado em 2.279.756.000 $\mathrm{m}^{3}$ com base do ano 2012 (Tabela 35), correspondente a $6.245 .907 \mathrm{~m}^{3}$ por dia. Considerando a disponibilidade na malha integrada na Figura 13 (MME, 2013b), até 2016 haveria um excedente de GN da ordem de 30 a 40 mil m³ por dia, sendo elevado a partir de 2017 e até 2021 para 50 a 60 mil m³ por dia em relação à demanda total média (demandas não termelétrica + termelétrica média). Além disso, deve-se considerar o fato importante de que a substituição da eletrotermia reduziria o consumo do gás natural utilizado na geração termelétrica num panorama crítico de insuficiência hidrelétrica.

- O potencial para demanda de GLP na substituição da eletrotermia foi consolidado em 1.807.375 ton com base no ano de 2012 (Tabela 35), correspondente a 4.952 ton por dia. No momento atual não haveria disponibilidade de GLP para atender esta nova demanda, desconsiderando-se a hipótese do aumento das importações. Mesmo considerando o panorama previsto na Figura 16, o equilíbrio entre a oferta nacional e a demanda ocorreria entre 2016 e 2017, sendo que o excedente de GLP deveria consolidar-se a partir de 2018 em cerca de 1.000.000 ton por ano não seria suficiente para atender com exclusividade à substituição da eletrotermia. 
É possível concluir-se, então, que haveria gás natural suficiente para atender à demanda na hipótese da substituição da eletrotermia e que o GLP poderia ser um importante vetor energético coadjuvante para o atendimento às regiões não atendidas pelo gás natural. Deve-se levar em conta, também, que a substituição da eletrotermia por gases combustíveis jamais abrangeria todo o potencial tecnológico estimado e que tal processo ocorreria lentamente ao longo dos anos vindouros.

\subsection{Eficiências da geração térmica}

As eficiências da geração térmica dependem da qualidade dos ciclos termodinâmicos das centrais elétricas, do porte dos equipamentos e, também, do regime de trabalho das usinas. A Figura 33 ilustra as eficiências dos ciclos termodinâmicos em função das temperaturas das fontes quentes, indicando a eficiência média das termelétricas no Brasil.

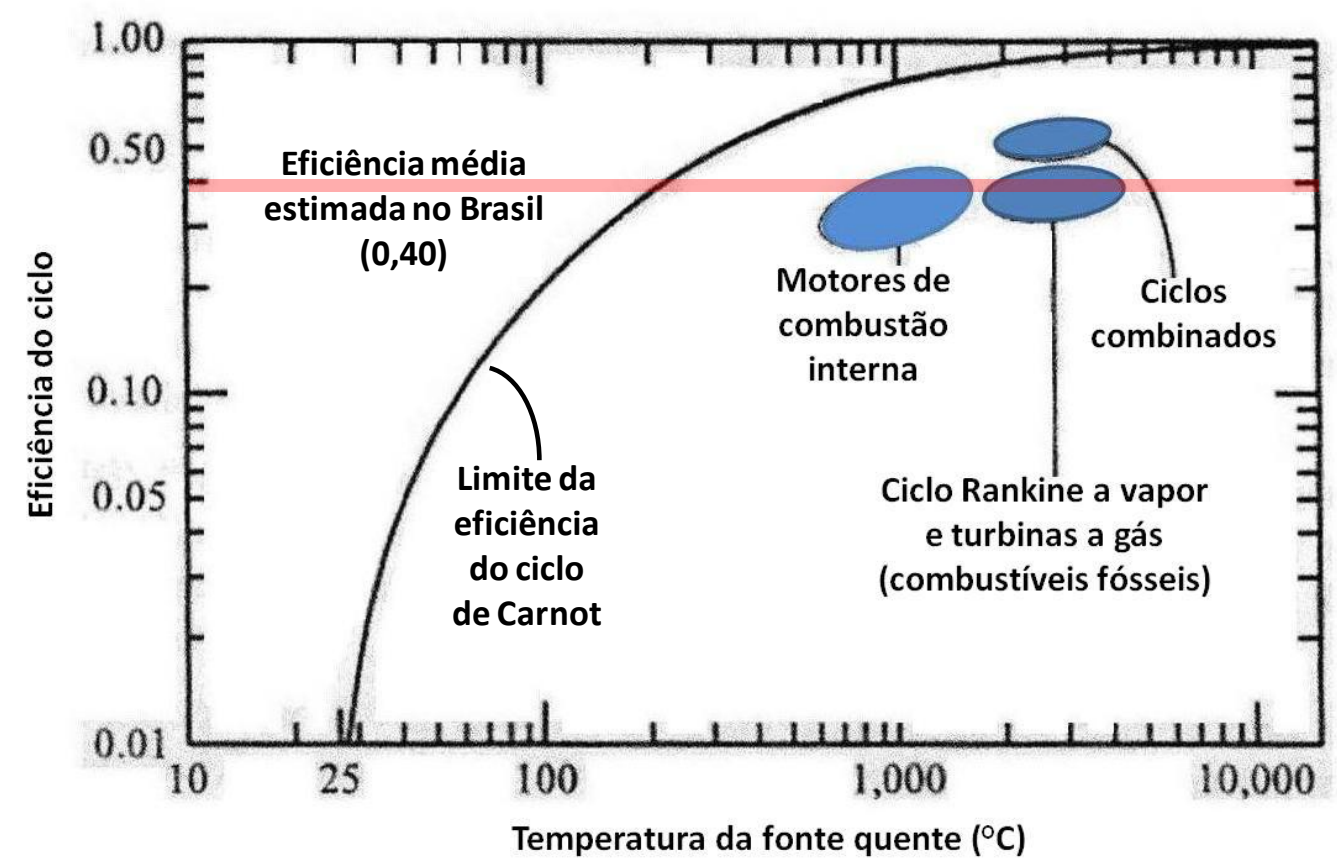

Figura 33 - Eficiência dos ciclos termodinâmicos

Fonte: elaboração adaptada de OLIVEIRA Jr, S.

As Tabelas 36 e 37 indicam a influência do regime de trabalho na tendência das eficiências da geração termelétrica, tanto nas centrais de serviço público como nas autoprodutoras. Quanto mais intenso o despacho das termelétricas, eficiências mais elevadas são obtidas de modo geral. Os dados destas tabelas permitem ainda o cálculo das eficiências médias nos períodos. 
Tabela 36 - Centrais termelétricas de serviço público - 2008 / 2012

\begin{tabular}{|c|c|c|c|c|c|}
\hline \multicolumn{6}{|c|}{ CENTRAIS TERMELÉTRICAS DE SERVIÇO PÚBLICO (valores de energia em $10^{3}$ tep) } \\
\hline COMBUSTÍVEIS CONSUMIDOS & em 2008 & em 2009 & em 2010 & em 2011 & em 2012 \\
\hline Gás natural & 4.565 & 1.574 & 4.818 & 2.897 & 6.700 \\
\hline Carvão vapor & 1.748 & 1.480 & 1.721 & 1.591 & 2.180 \\
\hline Lenha & 0 & 0 & 14 & 19 & 45 \\
\hline Óleo diesel & 1.597 & 1.361 & 1.820 & 1.696 & 2.261 \\
\hline Óleo combustível & 1.172 & 840 & 890 & 469 & 1.053 \\
\hline Urânio contido no $\mathrm{UO}_{2}$ & 3.641 & 3.377 & 3.780 & 4.081 & 4.180 \\
\hline Outras renováveis & 113 & 151 & 193 & 290 & 520 \\
\hline . Outras não renováveis & 0 & 0 & 0 & 51 & 53 \\
\hline TOTAL COMBUSTÍVEIS & 12.836 & 8.783 & 13.236 & 11.094 & 16.992 \\
\hline GERAÇÃO TÉRMICA & 4.965 & 3.223 & 5.178 & 4.223 & 6.845 \\
\hline EFICIÊNCIA GERAÇÃO TÉRMICA & $38,7 \%$ & $36,7 \%$ & $39,1 \%$ & $38,1 \%$ & $40,3 \%$ \\
\hline \multicolumn{6}{|c|}{ GERAÇÃO TÉRMICA MÉDIA ANUAL DE 2008 A $2012=4.887$ x $10^{3}$ tep $=56,83$ TWh } \\
\hline \multicolumn{6}{|c|}{ EFICIÊNCIA MÉDIA DA GERAÇÃO TÉRMICA NO PERÍODO $2008 / 2012=38,8 \%$} \\
\hline
\end{tabular}

Fonte: elaboração própria a partir do BEN (MME, 2013b)

Tabela 37 - Centrais termelétricas autoprodutoras - 2008 / 2012

\begin{tabular}{|c|c|c|c|c|c|}
\hline \multicolumn{6}{|c|}{ CENTRAIS TERMELÉTRICAS AUTOPRODUTORAS (valores de energia em $10^{3}$ tep) } \\
\hline COMBUSTÍVEIS CONSUMIDOS & em 2008 & em 2009 & em 2010 & em 2011 & em 2012 \\
\hline Gás natural & 1.156 & 1.046 & 2.177 & 2.331 & 2.353 \\
\hline . Carvão vapor & 83 & 43 & 184 & 159 & 161 \\
\hline Lenha & 311 & 221 & 295 & 267 & 258 \\
\hline Bagaço de cana & 2.067 & 2.687 & 4.081 & 3.982 & 4.427 \\
\hline Lixívia & 1.117 & 1.289 & 1.341 & 1.471 & 1.500 \\
\hline Outras recuperações & 971 & 1.088 & 854 & 1.092 & 1.171 \\
\hline Óleo diesel & 281 & 340 & 343 & 390 & 391 \\
\hline Óleo combustível & 312 & 300 & 238 & 265 & 293 \\
\hline Gás de coqueria & 527 & 331 & 304 & 301 & 265 \\
\hline Outras secundárias & 599 & 371 & 476 & 450 & 585 \\
\hline TOTAL COMBUSTÍVEIS & 7.424 & 7.716 & 10.293 & 10.708 & 11.404 \\
\hline GERAÇÃO TÉRMICA & 3.082 & 3.241 & 4.498 & 4.672 & 4.951 \\
\hline EFICIÊNCIA GERAÇÃO TÉRMICA & $41,5 \%$ & $42,0 \%$ & $43,7 \%$ & $43,6 \%$ & $43,4 \%$ \\
\hline \multicolumn{6}{|c|}{ GERAÇÃO TÉRMICA MÉDIA ANUAL DE 2008 A $2012=4.089$ x $10^{3}$ tep $=47,55$ TWh } \\
\hline \multicolumn{6}{|c|}{ EFICIÊNCIA MÉDIA DA GERAÇÃO TÉRMICA NO PERÍODO $2008 / 2012=43,00 \%$} \\
\hline
\end{tabular}

Fonte: elaboração própria a partir do BEN (MME, 2013b) 
Os processos de conversão de energia química em trabalho mecânico são processos de baixa eficiência. Nas centrais elétricas de serviço público a eficiência média significou 38,80\% e, nas autoprodutoras, $43,00 \%$.

A eficiência média ponderada da geração termelétrica no período de 2008 a 2012, considerando como peso a geração térmica média anual no mesmo período, foi de 40,71\%.

A eficiência destes processos só pode ser significativamente elevada no caso de cogeração, quando existe a possibilidade do aproveitamento local dos rejeitos térmicos para aplicação em processos de baixa temperatura como aquecimento de água e fluidos térmicos, geração de vapor, geração de ar quente e refrigeração através de ciclo de absorção.

\subsection{Fatores de conversão}

A determinação dos fatores de conversão (FC) é obtida a partir do inverso da eficiência de cada etapa considerada:

$\mathrm{FC}=1 /$ eficiência

Os fatores de conversão se referem a três etapas:

- Extração, processamento e transporte (FC1)

- Geração térmica (FC2)

- Transmissão e distribuição (FC3)

- Fator de conversão da Energia Final em Energia Primária: FC1 x FC2 x FC3

\subsubsection{Fator da extração, processamento e transporte de combustíveis}

Os fatores de conversão da energia primária para energia final referem-se à extração, ao processamento e ao transporte/distribuição, denominados neste capítulo como FC1 e, de acordo com Czachorski \& Leslie apud Cursino dos Santos (2011), são:

- gás natural:

- GLP:

- óleo diesel e óleos combustíveis:
Eficiência $=0,919 ; \quad F C 1=1 / 0,919=1,09$;

Eficiência $=0,913 ; \quad \mathrm{FC} 1=1 / 0,913=1,10$;

Eficiência $=0,892 ; \quad \mathrm{FC} 1=1 / 0,892=1,12$; 
- nuclear:

Eficiência $=0,951 ; \quad F C 1=1 / 0,951=1,05$;

- biomassa e resíduos:

Eficiência $=1,000 ; \quad \mathrm{FC} 1=1 / 1,000=1,00$;

- carvão vapor:

Eficiência $=0,957 ; \quad \mathrm{FC} 1=1 / 0,957=1,04$.

Consultando a fonte do Department of Energy and Department of Industry (1980), os citados fatores de conversão seriam 1,10 para o gás natural e 1,12 para os derivados de petróleo em geral, no qual estaria incluído o GLP, os quais são muito semelhantes aos fatores acima calculados. Resolveu-se então trabalhar com os fatores considerados por Cursino dos Santos (2011), por partirem de avaliações mais recentes. As diferenças mínimas entre as duas referências conferem credibilidade aos fatores de conversão considerados.

Foram considerados três panoramas para determinação dos fatores de conversão:

- centrais elétricas de serviço público;

- centrais elétricas autoprodutoras;

- ambas as centrais (serviço público e autoprodutoras).

A determinação do fator de conversão das centrais termelétricas de serviço público é realizada através da Tabela 38 .

Tabela 38 - Conversão de combustíveis consumidos em energia primária nas termelétricas de serviço público

\begin{tabular}{|c|c|c|c|}
\hline \multicolumn{4}{|c|}{ TERMELÉTRICAS DE SERVIÇO PÚBLICO (valores de energia em ktep) } \\
\hline COMBUSTÍVEIS CONSUMIDOS & Média 2008-2012 & FC1 & En. Primária \\
\hline . Gás natural & $4.110,8$ & 1,09 & $4.480,8$ \\
\hline . Carvão vapor & $1.744,0$ & 1,04 & $1.813,8$ \\
\hline Lenha & 15,6 & 1,00 & 15,6 \\
\hline . Óleo diesel & $1.747,0$ & 1,20 & $2.096,4$ \\
\hline . Óleo combustível & 884,8 & 1,20 & $1.061,8$ \\
\hline Urânio contido no $\mathrm{UO}_{2}$ & $3.811,8$ & 1,05 & $4.002,4$ \\
\hline Outras renováveis & 253,4 & 1,00 & 253,4 \\
\hline . Outras não renováveis & 20,8 & 1,20 & 25,0 \\
\hline TOTAIS & $12.588,2$ & 1,092 & $13.749,0$ \\
\hline
\end{tabular}

Fonte: elaboração própria; Czachorski \& Leslie apud Cursino dos Santos (2011); BEN (MME, 2013b)

Assim, o fator de conversão dos combustíveis consumidos para energia primária (FC1) a ser adotado para centrais termelétricas de serviço público é $\mathbf{1 , 0 9 2}$. 
O fator de conversão dos combustíveis para energia primária nas centrais termelétricas autoprodutoras é calculado na Tabela 39.

Tabela 39 - Conversão de combustíveis consumidos em energia primária nas termelétricas autoprodutoras

\begin{tabular}{lccc}
\hline \multicolumn{4}{c}{ TERMELÉTRICAS AUTOPRODUTORAS } \\
\multicolumn{1}{c}{ COMBalores de energia em ktep) } \\
\hline . Gás natural & $1.812,6$ & 1,09 & $1.975,7$ \\
. Carvão vapor & 126,0 & 1,04 & 131,0 \\
. Lenha & 270,4 & 1,00 & 270,4 \\
. Bagaço de cana & $3.448,8$ & 1,00 & $3.448,8$ \\
. Lixívia & $1.343,6$ & 1,00 & $1.343,6$ \\
. Outras recuperações & $1.035,2$ & 1,00 & $1.035,2$ \\
. Óleo diesel & 349,0 & 1,20 & 418,8 \\
. Óleo combustível & 281,6 & 1,20 & 337,9 \\
. Gás de coqueria & 345,6 & 1,00 & 345,6 \\
. Outras secundárias & 496,2 & 1,20 & 595,4 \\
\hline TOTAIS & $9.509,0$ & 1,041 & $9.902,5$ \\
\hline
\end{tabular}

Fonte: elaboração própria; Czachorski \& Leslie apud Cursino dos Santos (2011); BEN 2013

De forma análoga ao cálculo anterior, o fator de conversão FC1 a ser adotado para centrais elétricas autoprodutoras é 1,041.

Considerando agora todas as centrais de serviço público e autoprodutoras, tomando-se os dados das Tabelas 38 e 39, o fator de conversão FC1 é:

- consumo de combustíveis: $12.588,2+9.509,0=22.097,2 \mathrm{ktep}$

- energia primária: $\quad 13.749,0+9.902,5=23.651,5 \mathrm{ktep}$

$$
\mathrm{FC} 1=23.651,5 / 22.097,2 \mathrm{ktep}=\mathbf{1 , 0 7 3}
$$

\subsubsection{Fator da geração térmica de energia elétrica}

Os fatores de conversão para geração térmica (FC2) consideraram os valores médios para o período de 2008 a 2012, de forma a compensar efeitos sazonais da energia hidráulica. Como a eficiência média das centrais elétricas de serviço público calculada na Tabela 36 apresentou eficiência média diferente das centrais autoprodutoras calculada na Tabela 37, além do mix de 
energéticos ser diferente, os fatores de conversão para a geração foram calculados independentemente:

- termelétricas de serviço público: Eficiência $=0,388 ; \quad F C 2=1 / 0,388=2,58$

- termelétricas autoprodutoras: $\quad$ Eficiência $=0,430 ; \quad F C 2=1 / 0,430=2,33$

- todas as termelétricas: $\quad$ Eficiência $=0,407 ; \quad \mathrm{FC} 2=1 / 0,407=2,46$

\subsubsection{Fator da transmissão e distribuição de energia elétrica}

As perdas em energia elétrica, nas instalações de transmissão e de distribuição, podem ser subdivididas em dois grupos: perdas técnicas, inerentes aos fenômenos decorrentes do transporte e da transformação da energia elétrica através das redes e seus acessórios, como transformadores, chaves seccionadoras etc.; e perdas não técnicas ou comerciais, referentes à energia entregue mas não faturada como fraudes, furtos e erros de medição. Os valores apurados por Queiroz (2010), citando a fonte da ANEEL, estão expressos em percentagem da energia injetada e são as seguintes:

- redes de transmissão: perdas técnicas $=4,75 \%$

- $\quad$ redes de distribuição: perdas técnicas $=7,14 \%$;

- redes de distribuição: perdas não técnicas $=7,04 \%$

Assim, considerando 100,00 unidades de energia elétrica injetadas nas redes de transmissão, considerando as perdas técnicas de 4,75\%, apenas 95,25 unidades de energia são injetadas nas redes de distribuição. Injetando essas 95,25 unidades de energia nas redes de distribuição e considerando as perdas técnicas de 7,14\%, apenas 88,45 unidades de energia elétrica são entregues como energia final; não foram consideradas as perdas não técnicas, pois estas não sofreriam influência na hipótese da substituição da eletrotermia.

Fator de transmissão e distribuição de energia elétrica:

- eficiência $=0,8845$;

- $\mathrm{FC} 3=1 / 0,8845=1,13$. 


\subsection{Comparação da substituição da eletrotermia por GN e GLP}

A partir dos cálculos anteriores, foi montada a planilha da Tabela $40 \mathrm{com}$ os valores das energias finais, a partir da consolidação dos potenciais para conversão de eletrotermia em aquecimento direto e calor de processo e os gases combustíveis substitutos informados na Tabela 35, onde já estão corrigidos para 2012, de forma a estimar e possibilitar a comparação dos respectivos consumos de energia primária:

- $\quad$ energia final - potencial para substituição de eletricidade: $1.796,5$ ktep $=\mathbf{2 0 , 8 9}$ TWh

- energia final - gases combustíveis substitutos: $\quad 2.006,2$ ktep

Os fatores de conversão de energia final para energia primária considerados na Tabela 40 são os seguintes:

- o fator de conversão médio para a eletricidade oriunda de todas as fontes considerado por Cursino dos Santos (2011) foi 1,44, o qual levou em conta a eficiência de transmissão e distribuição de 84,4\%, (fator FC3 = $1 /$ 0,844 =1,18); como o fator de transmissão e distribuição considerando nesta tese foi o FC3 $=1,13$ torna-se necessário fazer as devidas correções para que as comparações sejam coerentes:

$1,44 \times 1,13 / 1,18=1,38$

- os fatores FC1, FC2 e FC3 para as termelétricas, calculados nos itens 7.3.1, 7.3.2 e 7.3.3:

- termelétricas de serviço público: $1,092 \times 2,58 \times 1,13=3,18$

- termelétricas autoprodutoras: $\quad 1,041 \times 2,33 \times 1,13=2,74$

- mix de ambas as termelétricas: $1,073 \times 2,46 \times 1,13=2,98$

- e os fatores FC1 especificamente citados para o GLP e o GN no item 7.3.1.

- para o gás natural: $\quad 1,09$

- para o gás liquefeito de petróleo: $\quad 1,10$

Da Tabela 40 pode ser concluído que a substituição da eletrotermia por gases combustíveis é vantajosa em todas as situações comparando-se as energias primárias, apesar dos valores das 
energias finais serem mais elevados na opção dos gases combustíveis devido às eficiências mais baixas do uso final em relação à eletricidade.

Tabela 40 - Comparação das conversões de energia final em energia primária

\begin{tabular}{|c|c|c|c|}
\hline \multicolumn{2}{|c|}{ ENERGIA FINAL } & \multirow{2}{*}{$\begin{array}{c}\text { FATOR DE } \\
\text { CONVERSÃO }\end{array}$} & \multirow{2}{*}{$\begin{array}{c}\text { ENERGIA PRIMÁRIA } \\
\text { (ktep) }\end{array}$} \\
\hline Vetor & (ktep) & & \\
\hline $\begin{array}{c}\text { Eletricidade } \\
\text { (todas as fontes) }\end{array}$ & $1.796,5$ & $1,38^{(1)}$ & $2.479,2$ \\
\hline $\begin{array}{c}\text { Eletricidade } \\
\text { (term. serv. público) }\end{array}$ & $1.796,5$ & $3,18^{(1),(2)}$ & $5.712,9$ \\
\hline $\begin{array}{c}\text { Eletricidade } \\
\text { (term. autoprodutoras) }\end{array}$ & $1.796,5$ & $2,74^{(1),(2)}$ & $4.922,4$ \\
\hline $\begin{array}{c}\text { Eletricidade } \\
\text { (todas as termelétricas) }\end{array}$ & $1.796,5$ & $2,98^{(1),(2)}$ & $5.353,6$ \\
\hline Gás natural & $2.006,2$ & $1,09^{(1)}$ & $2.186,8$ \\
\hline $\begin{array}{l}\text { Gás liquefeito } \\
\text { do petróleo }\end{array}$ & $2.006,2$ & $1,10^{(1)}$ & $2.206,8$ \\
\hline
\end{tabular}

Fonte: elaboração própria; Cursino dos Santos $(2011)^{(1)}$; Queiroz (2010) ${ }^{(2)}$

A vantagem da opção gases combustíveis torna-se notadamente significativa na conversão da eletrotermia, quando acarreta em redução expressiva do consumo de energia primária oriunda da geração térmica.

As economias percentuais em energia primária, na substituição da eletrotermia por gases combustíveis, de acordo com a Tabela 40, são as seguintes:

- de eletricidade (todas as fontes) para GN: $\quad 11,8 \%$

- de eletricidade (geração termelétrica de serv. público) para GN: $61,7 \%$

- de eletricidade (geração termelétrica autoprodutores) para GN: 55,6\%

- de eletricidade (geração por todas as termelétricas) para GN: $\quad 59,2 \%$ 
- de eletricidade (todas as fontes) para GLP: $11,0 \%$

- de eletricidade (geração termelétrica de serv. público) para GLP: 61,4\%

- de eletricidade (geração termelétrica autoprodutores) para GLP: 55,2\%

- de eletricidade (geração por todas as termelétricas) para GLP: $\quad 58,8 \%$

\subsection{Conclusões do capítulo 7}

Os cálculos das economias percentuais em energia primária indicam resultados significativos considerando-se a geração termelétrica, onde as reduções são significativas e ultrapassam a $55 \%$. Mesmo considerando todas as fontes de geração de eletricidade, economias em energia primária ainda são encontradas. Cabe refletir sobre a substituição da eletrotermia por gases combustíveis, com respeito a qual grupo de centrais elétricas sofreria o impacto mais significativo na redução da geração. Certamente, no momento atual e em futuro próximo, a maior probabilidade recairia sobre as termelétricas de serviço público, as quais complementam a oferta do sistema.

Torna-se necessário lembrar que os resultados encontrados tomaram por base os dados informados no BEU 2005 (ano base 2004) e o BEN 2013 (ano base 2012), estando portanto limitados à precisão das informações destas fontes. 


\section{ASPECTOS ECONÔMICOS NA SUBSTITUIÇÃO DA ELETROTERMIA}

O capítulo 8 apresenta alguns aspectos econômicos referentes à conversão da energia elétrica para gases combustíveis, pois investimentos, prazos de retorno e custos operacionais fazem parte dos anteprojetos e das estratégias das empresas. Essas avaliações econômicas abrangem aspectos do ponto de equilíbrio do preço dos energéticos e dos principais investimentos.

\subsection{Equivalência econômica gás $\mathrm{x}$ eletricidade}

Em alguns casos, a conversão para a opção gás torna-se necessária por motivos estratégicos, onde a avaliação econômica pode adquirir um aspecto secundário em virtude de alguns aspectos como:

- limitação na disponibilidade local de energia elétrica;

- não confiabilidade na continuidade do fornecimento, como apagões frequentes;

- não confiabilidade na qualidade do fornecimento, como variações na voltagem e presença de ruídos elétricos;

- custos elevados da energia elétrica nos horários de pico;

- pagamento de multas por ultrapassagem da demanda contratada.

Neste particular de motivos estratégicos pode ser citado o apagão colombiano nos anos 1992 e 1993, devido ao baixíssimo nível dos reservatórios hídricos causado pelo fenômeno "El Niño" e associado a um parque termelétrico capaz de atender apenas a $22 \%$ da demanda nacional naquela ocasião, o qual exigiu a mudança do autor para este país a fim de realizar conversões de eletrotermia para gás natural, petróleo e seus derivados. Naquela ocasião, as áreas residenciais e comerciais em Bogotá sofriam 9 horas de racionamento de energia elétrica por dia (apagão), o que causava grandes transtornos à população em virtude do uso intensivo da eletrotermia nas residências, tanto no aquecimento de água como na cocção de alimentos (forno e fogão).

Assim, os esforços da conversão da eletrotermia foram dedicados às indústrias em geral e, particularmente, às siderúrgicas semi-integradas e às indústrias de vidro de grande porte. As siderúrgicas semi-integradas têm seus principais equipamentos, os fornos elétricos a arco e os fornos-panela dependentes da energia elétrica como fonte de calor. E, por sua vez, as 
indústrias de vidro de grande porte tinham eletrodos nos fornos de fusão, projetados para complementar a potência gerada por queimadores e adequar o perfil de temperaturas. A indisponibilidade da energia elétrica para o atendimento a esses segmentos industriais estava causando sérios problemas, principalmente a baixa produtividade. A solução encontrada, em ambos os casos, foi a instalação de queimadores auxiliares gás-oxigênio ou óleo-oxigênio restaurando a produtividade original nesses segmentos. O principal motivo do emprego da oxi-combustão foi a necessidade de se fornecer a maior potência possível gerando o mínimo de produtos da combustão, pois os equipamentos não haviam sido projetados para o tráfego adicional destes gases, tanto na câmara de processo como nos sistemas de exaustão e seus periféricos como regeneradores e filtros antipoluição.

Um método para fazer uma avaliação econômica preliminar da conversão baseia-se na simples comparação entre os energéticos, eletricidade e gás, partindo-se das premissas que as perdas térmicas estruturais, antes e após a conversão, apresentem valores idênticos ou muito próximos e que as energias líquidas, fornecidas ao equipamento térmico em ambas as opções, sejam também iguais. Devem então ser consideradas as razões entre os rendimentos térmicos do equipamento com energia elétrica e gás combustível, o que possibilita estimar o preço de equilíbrio entre as tarifas de energia elétrica em função dos preços de gás e vice-versa, através das Tabelas 41 e 42 apresentadas no Apêndice B (gás natural) e no Apêndice C (GLP).

A elaboração destas tabelas considerou as seguintes relações, onde os poderes caloríficos inferiores (PCIs) foram informados nas respectivas unidades de comercialização, ou seja, gás natural em metro cúbico na temperatura de $20^{\circ} \mathrm{C}$ e a uma atmosfera absoluta (pressão atmosférica no nível do mar) e o GLP em quilogramas:

- $1 \mathrm{MWh}=860.000 \mathrm{kcal}$

- $\quad$ PCI do gás natural = $8.800 \mathrm{kcal} / \mathrm{m}^{3} @ 20^{\circ} \mathrm{C}, 1 \mathrm{~atm}$ abs (ANP, 2012)

- $\quad$ PCI do GLP $=11.100 \mathrm{kcal} / \mathrm{kg}(\mathrm{ANP}, 2012)$

Assim, a equivalência energética corresponde a:

$1 \mathrm{MWh}=97,73 \mathrm{~m}^{3} \mathrm{GN}=77,48 \mathrm{~kg} \mathrm{GLP}$

Cada tabela fixou um valor para o rendimento do equipamento com o uso da energia elétrica, variando o rendimento estimado com o gás combustível após a conversão. Os números 
indicados nas matrizes indicam os valores equivalentes para a energia elétrica em $\mathrm{R} \$ / \mathrm{MWh}$, levando em conta a faixa de preços praticados na comercialização dos gases combustíveis com tributos.

A tarifa média da classe de consumo industrial - Brasil em 2013 foi encontrada em: http://relatorios.aneel.gov.br , consulta em 02/08/2013

Os valores médios indicados para as tarifas da classe industrial são:

- com tributos, $\mathrm{R} \$ 303,72$ por MWh;

- sem tributos, $\mathrm{R} \$ 225,79$ por MWh.

Embora esta avaliação não seja um método que possa ser considerado final, por exigir o conhecimento prévio dos rendimentos térmicos de cada equipamento com cada energético, ela possibilita a estimativa da ordem de grandeza dos valores envolvidos no estudo da conversão da energia elétrica para os gases combustíveis.

Os valores para os custos equivalentes a $1 \mathrm{MWh}$ foram calculados levando-se em conta as fórmulas:

- Para gás natural: $\quad$ VMWH $=97,73 \times$ PGN $\times$ REE / RGN

- Para GLP: $\quad$ VMWH $=77,48 \times$ PGL $\times$ REE $/$ RGL

onde:

- VMWH: $\quad$ valor em R $\$$ equivalente do MWh

- PGN: preço do GN em $\mathrm{R} \$ / \mathrm{m}^{3}$

- PGL: $\quad$ preço do GLP em $\mathrm{R} \$ / \mathrm{kg}$

- REE: rendimento do processo com energia elétrica

- RGN: rendimento do processo com GN

- RGL: rendimento do processo com GLP

Para uma visualização mais fácil, as referidas tabelas foram expressas sob forma gráfica através da Figura 34 para gás natural e da Figura 35 para GLP. 


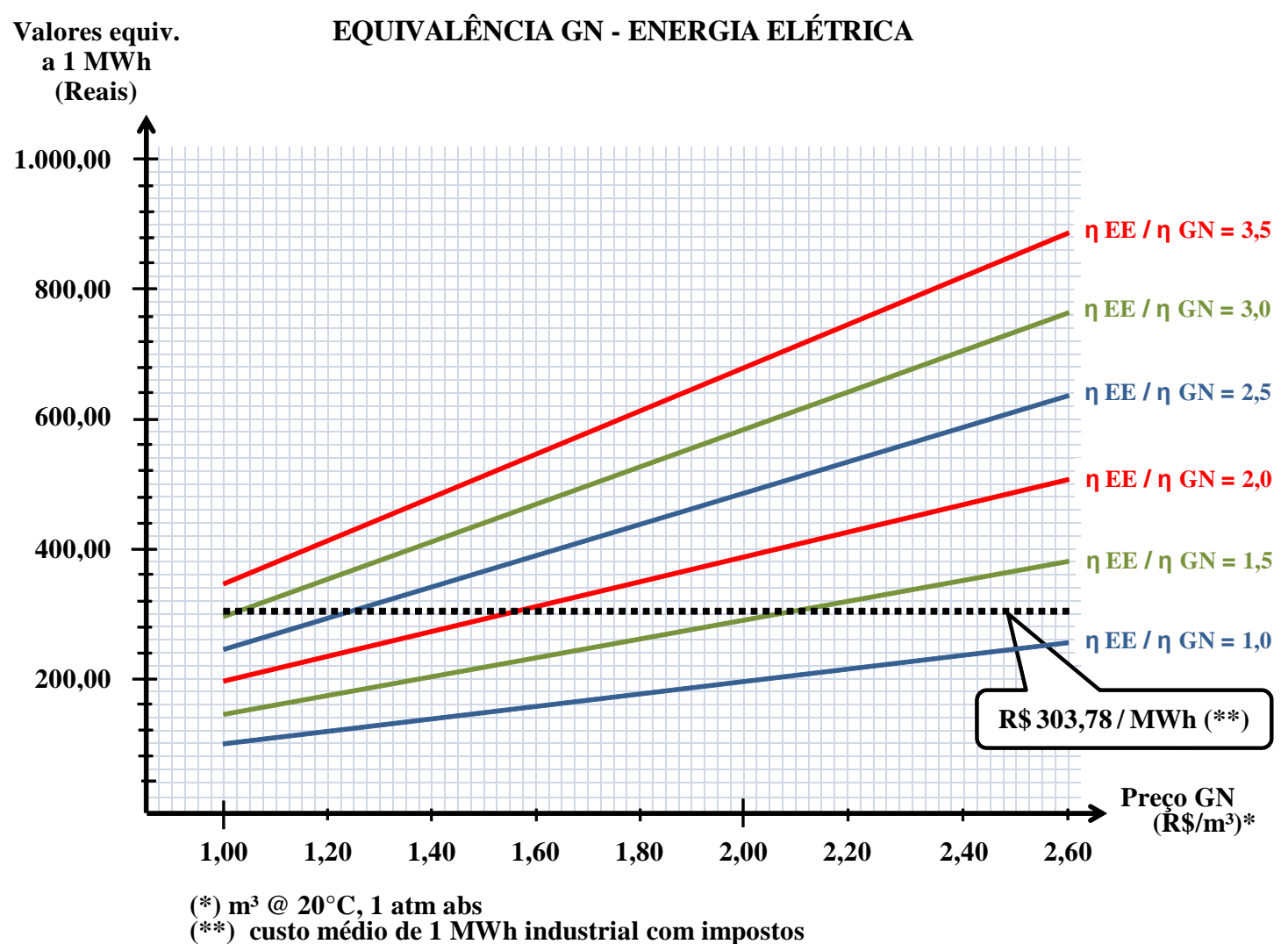

Figura 34 - Equivalência GN - energia elétrica Fonte: elaboração própria

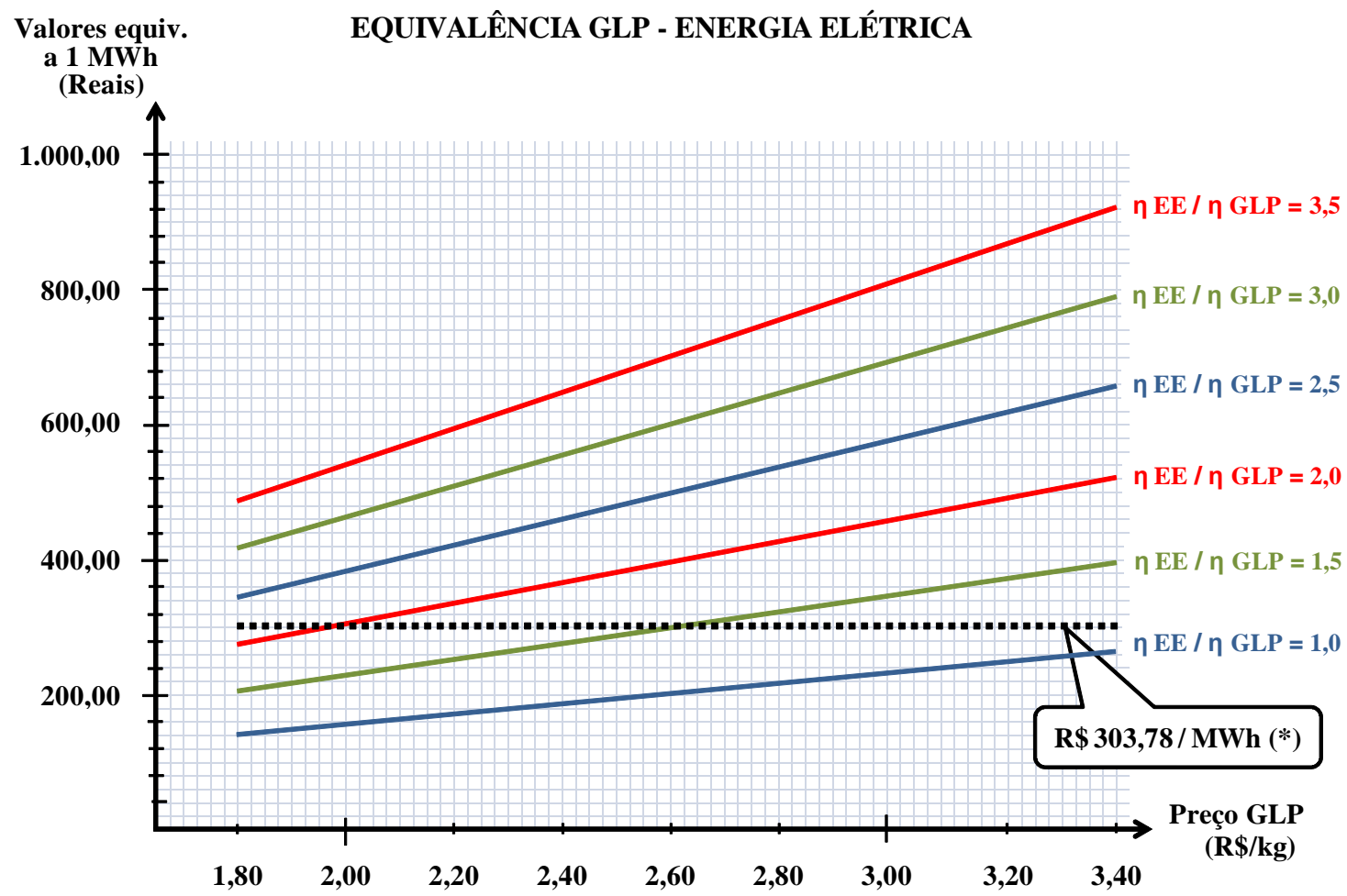

(*) custo médio de 1 MWh industrial com impostos

Figura 35 - Equivalência GLP - energia elétrica Fonte: elaboração própria 
As Figuras 34 e 35 mostram claramente a existência de regiões onde os pontos de equilíbrio tornam viáveis as conversões, principalmente no entorno da linha pontilhada que indica o preço médio do megawatt-hora para a indústria e regiões inferiores. Embora dificilmente a relação entre as eficiências da energia elétrica e dos gases combustíveis superem ao número dois, o autor incluiu valores superiores caso ocorram situações excepcionais.

\subsection{Investimentos na conversão}

Além dos custos operacionais dos energéticos, considerando seus respectivos rendimentos, deve-se também levar em conta os investimentos necessários para o processo de conversão de eletricidade para gás e, também, os custos de manutenção preventiva e corretiva.

No caso de aquecimento direto, a conversão de um equipamento elétrico, geralmente do tipo resistivo, para gás combustível, a ação principal é a compra e a instalação de um ou mais queimadores, cavalete(s) e painel de controle, atendendo à edição vigente da norma brasileira da ABNT NBR 12313 - Sistemas de combustão, controle e segurança para a utilização de gases combustíveis em processos de baixa e alta temperatura. Além disso, os custos típicos de investimento podem exigir ou não a consideração de uma ou mais das seguintes atividades:

- estudo e projeto para a conversão, incluindo um possível remanejamento da carga a ser processada pelo equipamento devido à introdução da chama e ao trajeto dos produtos da combustão do gás;

- retirada das resistências elétricas e seus periféricos, embora também haja a possibilidade da manutenção do equipamento dual (eletricidade-gás);

- alteração na estrutura do equipamento, preparando-o para a instalação do(s) queimador(es), do(s) bloco(s) refratário(s) e do sistema de exaustão para os produtos da combustão (dutos, chaminés, exaustores etc.);

- instalação, caso necessário, de dispositivos para confinamento total ou parcial da chama em função de características peculiares do equipamento ou da carga a ser processada, como tubos radiantes e muflas;

- integração eventual do painel de controle do(s) queimador(es) com o processo realizado pelo equipamento térmico; 
- compra e instalação de equipamentos relacionados com a conservação de energia, como trocadores de calor para preaquecimento do ar de combustão (recuperadores ou regeneradores), quando desejável ou necessário aumentar o rendimento;

- compra e instalação de equipamentos destinados à conservação de energia e ao aumento de produtividade, como no caso do aproveitamento dos produtos da combustão após a saída do equipamento térmico para pré-secagem ou preaquecimento da carga.

- consultoria especializada para a partida do equipamento, se necessária.

Outra possibilidade frequentemente presente na conversão eletricidade-gás é o aumento da produtividade, como consequência direta do aumento da potência líquida do equipamento, conforme já citado anteriormente.

Para a conversão eletricidade-gás, além da instalação do sistema de combustão, é também necessário levar o gás combustível até o equipamento quando não existe rede de distribuição interna ou, caso exista, não haja capacidade disponível para tal. Assim, os seguintes investimentos adicionais também devem ser considerados quando seus custos correrem por conta do consumidor:

- conjunto de regulagem e medição (CRM), no caso de gás natural canalizado; central de gás natural comprimido (cilindros de alta pressão, sistemas de descompressão e regulagem inicial da pressão); central de gás natural liquefeito - GNL (tanques criogênicos, sistemas de vaporização e regulagem inicial da pressão); ou central de GLP (recipientes pressurizados, sistema de vaporização e regulagem inicial da pressão);

- rede de distribuição interna de gás.

No caso de calor de processo, praticamente todos os casos exigem a substituição das caldeiras e dos aquecedores elétricos por seus correspondentes a gás combustível. Havendo possibilidade, é prudente a manutenção dos equipamentos elétricos instalados em condição de operar em paralelo com os equipamentos a gás, caso estes se tornem eventualmente inoperantes como em necessidade de manutenção ou falta de combustível. 
Caso já exista rede de distribuição interna de gás com suficiente capacidade para o acréscimo de consumo, os investimentos são significativamente mais baixos resumindo-se na derivação da rede para o novo equipamento térmico.

Dependendo das condições de negociação e da concorrência local, os investimentos citados poderão ser, no todo ou em parte, realizados pela distribuidora de gás. Nesta hipótese, em contrapartida, o consumidor costuma assinar um contrato de exclusividade de fornecimento com a distribuidora por um período suficiente para que o retorno do investimento seja realizado através de uma parcela incorporada ao preço de venda do gás. É comum, também, que estes contratos tenham cláusula de consumo mínimo, tipo take-or-pay, e que transfiram a propriedade dos bens investidos, no todo ou em parte, para o consumidor no término do período contratual, geralmente não inferior a cinco anos. Habitualmente os bens que costumam passar à propriedade dos consumidores são as tubulações de gás e os queimadores. Mas existem casos onde podem ser incorporados, pela empresa consumidora, equipamentos como fornos, secadores, caldeiras e aquecedores.

Com o objetivo de permitir a realização de estimativas a respeito dos investimentos necessários nas conversões de eletrotermia para gases combustíveis, com respeito a aquecimento direto, foram consultadas algumas empresas que comercializam e instalam queimadores. Os queimadores foram agrupados de acordo com suas características, desde os mais simples com controle do tipo liga-desliga, até os mais sofisticados com controle modulante de potência. Os valores para os queimadores consultados em empresas atuantes no mercado brasileiro estão informados em reais, segundo suas respectivas potências máximas, os quais permitiram a plotagem de curvas, conforme mostram as Figuras 36, 37, 38 e 39.

Devido à significativa participação de componentes importados, cabe informar que esta pesquisa foi realizada na segunda quinzena do mês de junho de 2013, quando a cotação de venda do dólar comercial norte-americano variou entre $\mathrm{R}$ 2,1661 e R\$ 2,2580 (site economia.uol.com.br)

As Figuras 36 e 37 referem-se aos custos dos queimadores convencionais do tipo monobloco com três configurações operacionais:

- liga-desliga;

- chama baixa-chama alta;

- modulante. 
A Figura 36 mostra as curvas de custo dos queimadores tipo monobloco para gás natural, de acordo com as potências e tipos de acionamento. A Figura 37 mostra também as curvas de custo para os queimadores monobloco, agora para GLP. As diferenças de custo entre ambos os gases são devidas aos seus diferentes Índices de Wobbe: o do gás natural é $11.770 \mathrm{kcal} / \mathrm{m}^{3}$ e o do GLP é $19.555 \mathrm{kcal} / \mathrm{m}^{3}$. Estes valores implicam na adoção de diâmetros maiores em todo o tráfego do gás natural, inclusive nas válvulas do cavalete de bloqueio e controle do fluxo de gás dos queimadores, exigindo menores diâmetros para o GLP, considerando potência e pressão iguais. Assim, um queimador a GLP apresenta um preço de venda correspondentemente inferior ao mesmo modelo a gás natural, para a mesma potência.

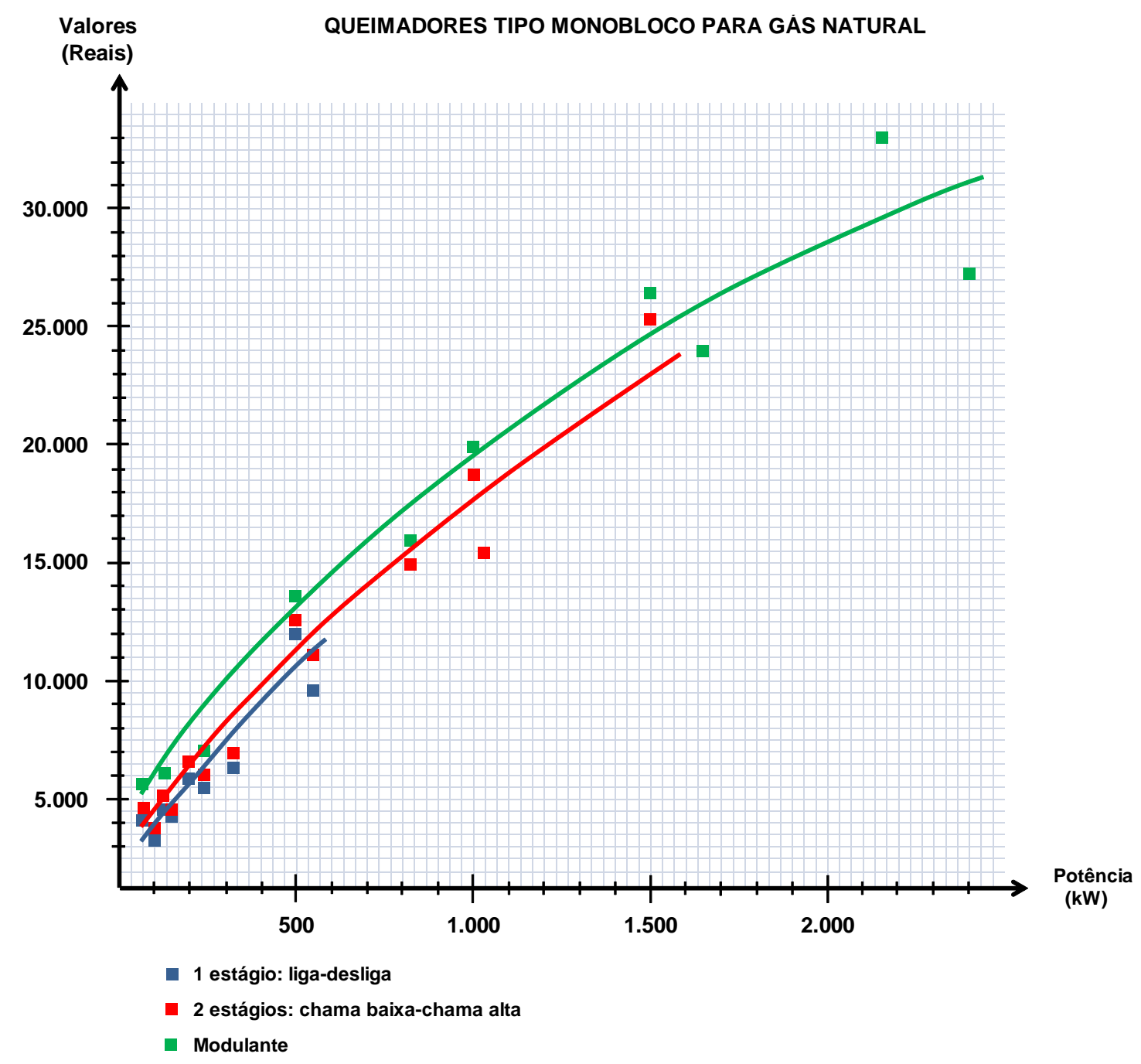

Figura 36 - Curva de preços para queimadores monobloco para GN

Fonte: elaboração própria 
Outro fator que pode alterar significativamente os preços de um queimador é a qualidade dos seus componentes. Queimadores com elevado grau de confiabilidade e/ou que emitam baixo teor de NOx são geralmente mais caros que os queimadores convencionais. As cotações apresentadas dizem respeito aos queimadores convencionais, por ser a grande maioria das unidades comercializadas no Brasil.

Assim, de acordo com a Figura 36, os preços específicos médios para queimadores convencionais do tipo monobloco, a gás natural, são:

- tipo 1 estágio: $\mathrm{R} \$ 24,67 / \mathrm{kW}$ (baixa potência)

- tipo 2 estágios: $\mathrm{R} \$ 27,50 / \mathrm{kW}$ (baixa potência); $\mathrm{R} \$ 17,60 / \mathrm{kW}$ (média potência)

- tipo modulante: $\mathrm{R} \$ 33,33 / \mathrm{kW}$ (baixa potência); $\mathrm{R} \$ 19,80 / \mathrm{kW}$ (média potência);

$\mathrm{R} \$ 13,26 / \mathrm{kW}$ (alta potência)

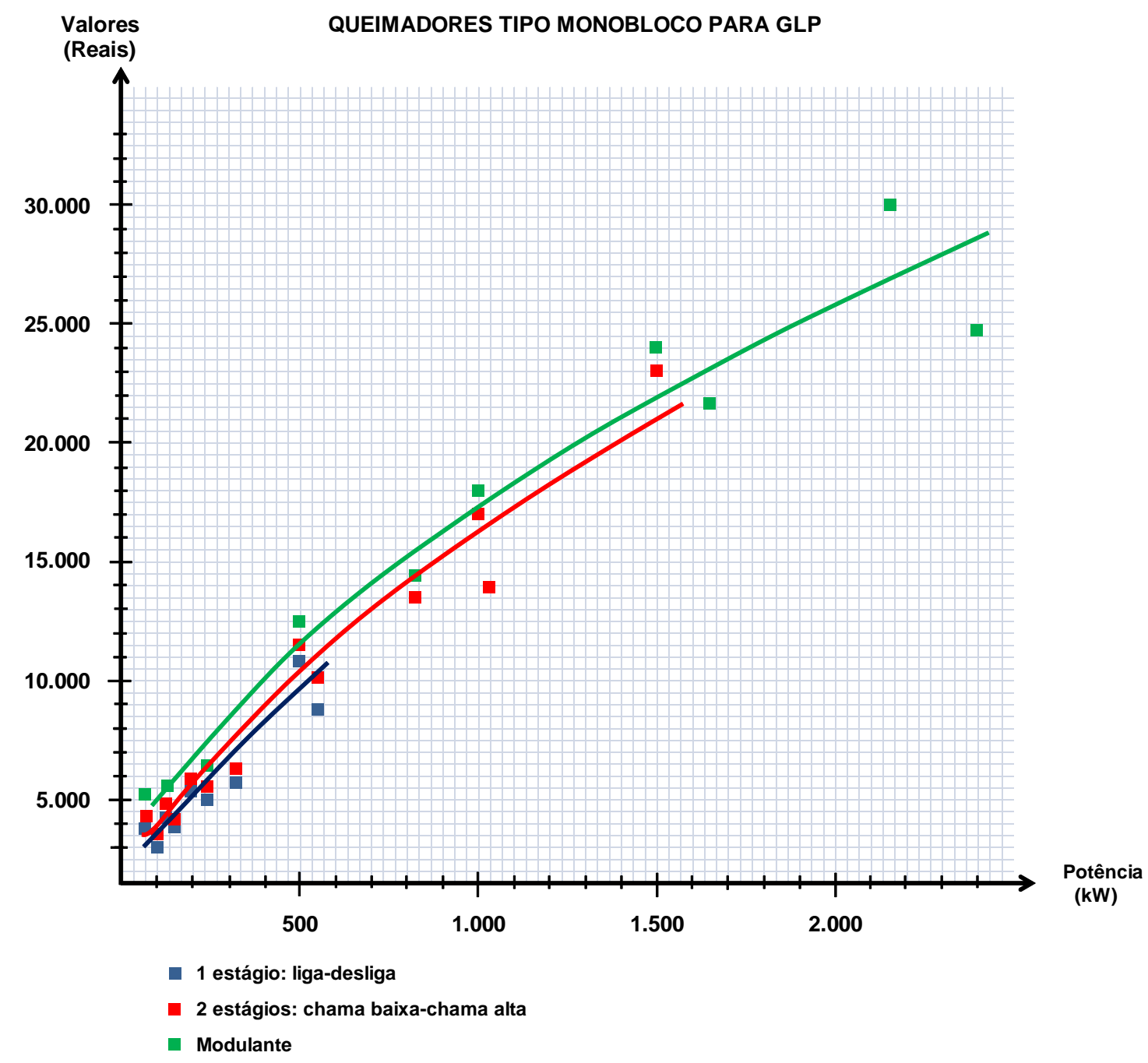

Figura 37 - Curva de preços para queimadores monobloco para GLP

Fonte: elaboração própria 
Observação: foram consideradas as seguintes potências para cálculo dos preços específicos médios dos queimadores de baixas, médias e altas potências, respectivamente: $300 \mathrm{~kW}$; $1.000 \mathrm{~kW} ;$ e $2.300 \mathrm{~kW}$.

Assim, de acordo com a Figura 37, os preços específicos médios para queimadores convencionais do tipo monobloco, a GLP, são:

- tipo 1 estágio: $\mathrm{R} \$ 22,50 / \mathrm{kW}$ (baixa potência)

- tipo 2 estágios: $\mathrm{R} \$ 24,50 / \mathrm{kW}$ (baixa potência); $\mathrm{R} \$ 16,20 / \mathrm{kW}$ (média potência)

- tipo modulante: $\mathrm{R} \$ 28,33 / \mathrm{kW}$ (baixa potência); $\mathrm{R} \$ 17,20 / \mathrm{kW}$ (média potência)

$\mathrm{R} \$ 12,13 / \mathrm{kW}$ (alta potência)

A Figura 38 mostra as curvas de custo dos queimadores tipo duobloco para gás natural, de acordo com as potências e tipos de acionamento.

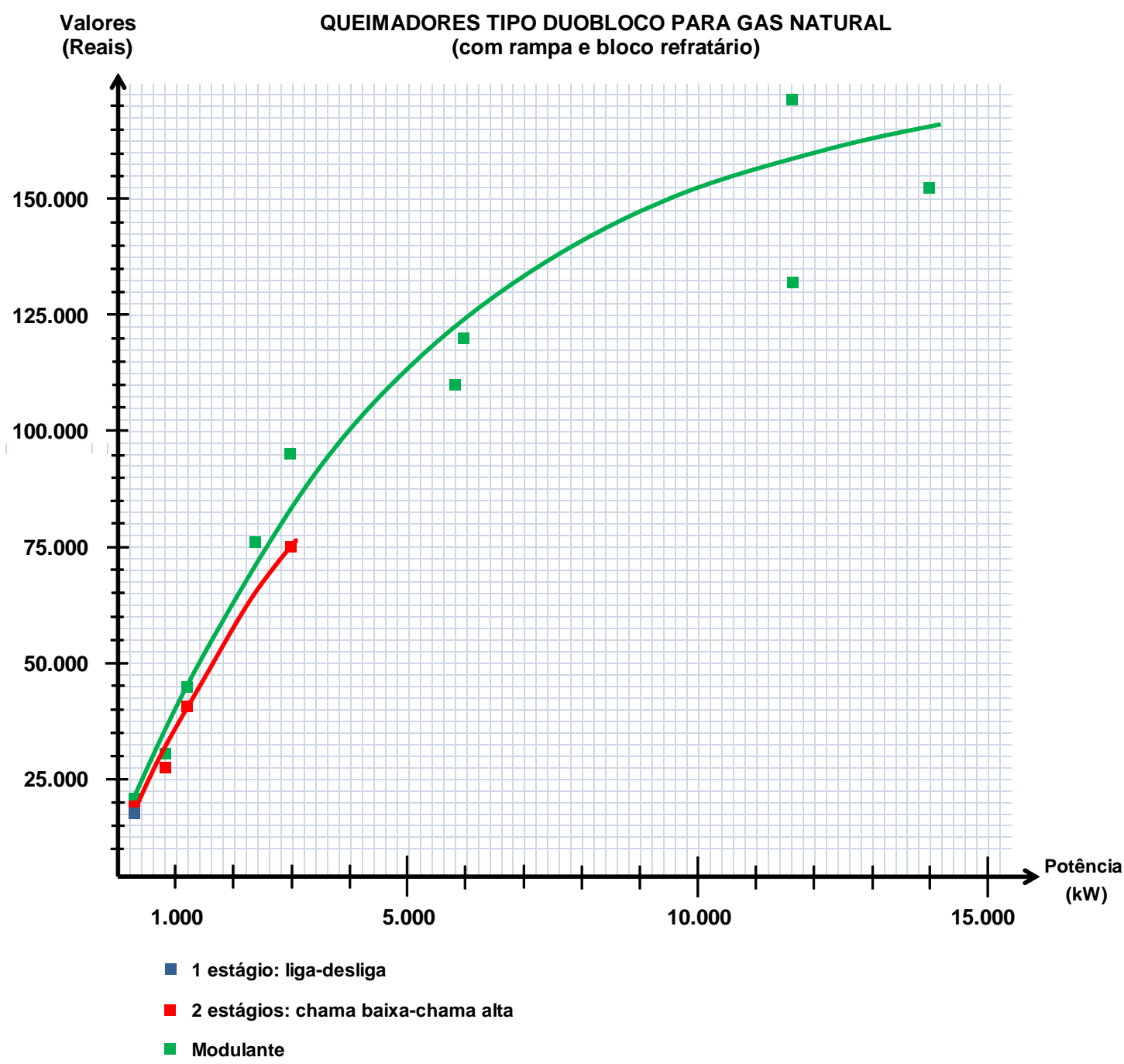

Figura 38 - Curva de preços para queimadores duobloco para GN

Fonte: elaboração própria 
Assim, de acordo com a Figura 38, os preços específicos médios para queimadores convencionais do tipo duobloco, a gás natural, são:

- tipo 1 estágio: $\mathrm{R} \$ 58,33 / \mathrm{kW}$ (baixa potência)

- tipo 2 estágios: $\mathrm{R} \$ 62,50 / \mathrm{kW}$ (baixa potência); $\mathrm{R} \$ 25,00 / \mathrm{kW}$ (média potência)

- tipo modulante: $\mathrm{R} \$ 70,00 / \mathrm{kW}$ (baixa potência); $\mathrm{R} \$ 28,00 / \mathrm{kW}$ (média potência);

$\mathrm{R} \$ 13,33 / \mathrm{kW}$ (alta potência)

Observação: foram consideradas as seguintes potências para cálculo dos preços específicos médios dos queimadores de baixas, médias e altas potências, respectivamente: $300 \mathrm{~kW}$; $3.000 \mathrm{~kW}$; e $12.000 \mathrm{~kW}$.

A Figura 39 mostra as curvas de custo para os queimadores duobloco, agora para GLP.

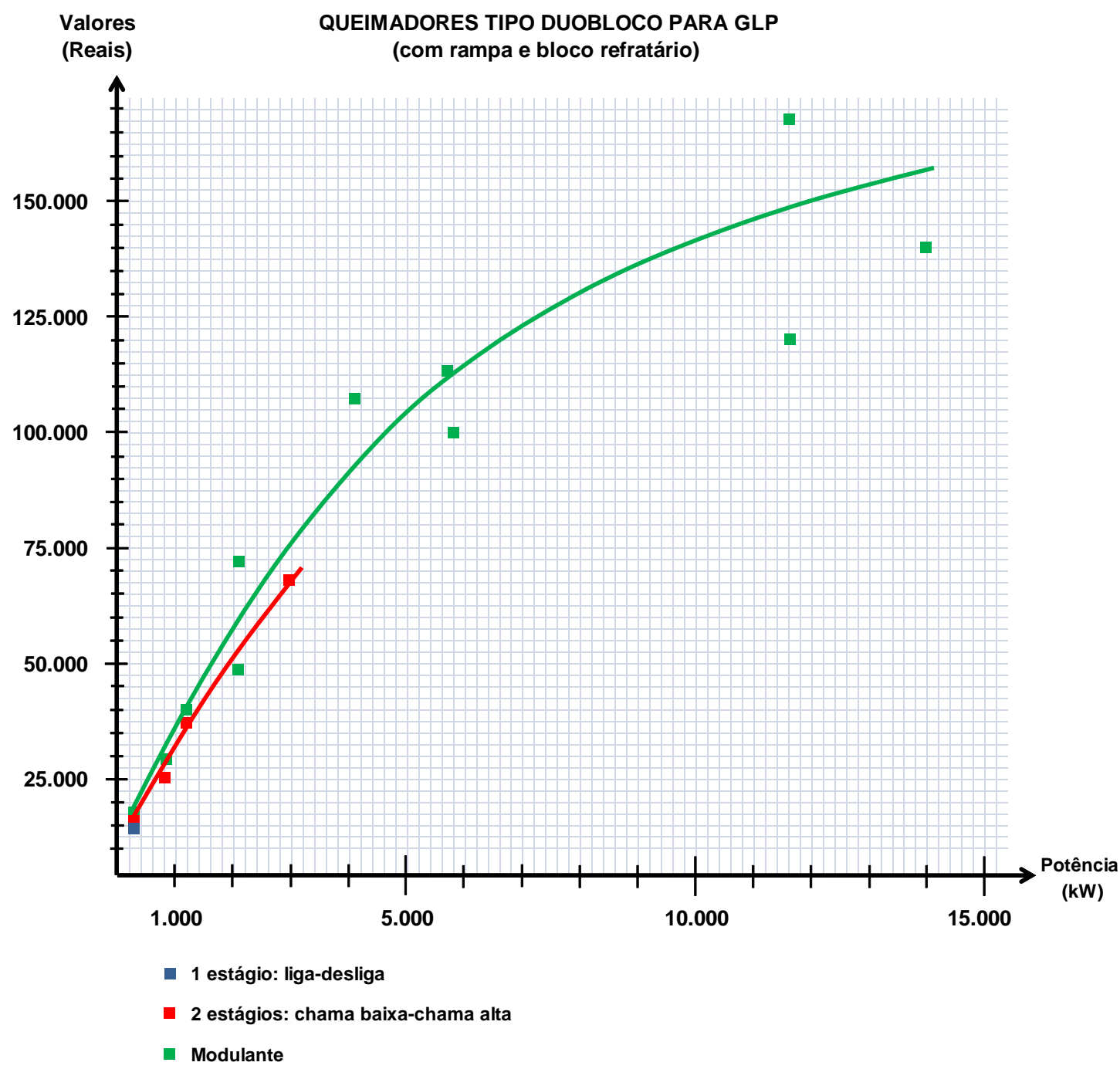

Figura 39 - Curva de preços para queimadores duobloco para GLP

Fonte: elaboração própria 
Assim, de acordo com a Figura 39, os preços específicos médios para queimadores convencionais do tipo duobloco, a GLP, são:

- tipo 1 estágio: $\mathrm{R} \$ 50,00 / \mathrm{kW}$ (baixa potência)

- tipo 2 estágios: $\mathrm{R} \$ 54,17 / \mathrm{kW}$ (baixa potência); $\mathrm{R} \$ 22,50 / \mathrm{kW}$ (média potência)

- tipo modulante: $\mathrm{R} \$ 70,00 / \mathrm{kW}$ (baixa potência); $\mathrm{R} \$ 25,42 / \mathrm{kW}$ (média potência);

$\mathrm{R} \$ 12,50 / \mathrm{kW}$ (alta potência)

A Figura 40 apresenta os preços das caldeiras a vapor saturado mais utilizadas em calor de processo, do tipo flamotubulares, com pressão máxima de trabalho admissível (PMTA) de 150 psig. Caldeiras de maior porte, como as aquatubulares, são configuradas praticamente sob encomenda e, pela grande variação entre seus valores, não foram mencionadas.

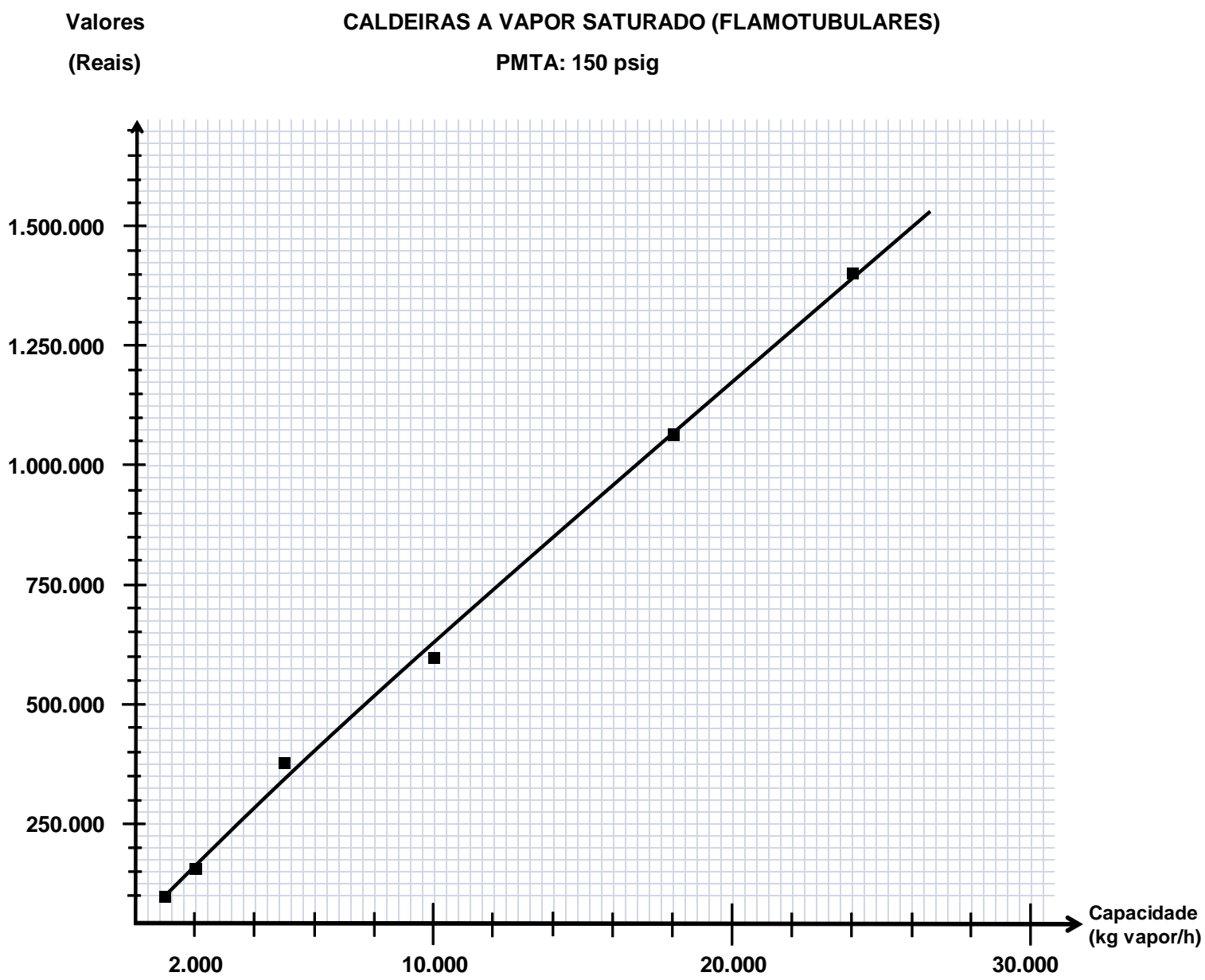

Figura 40 - Preço de caldeiras flamotubulares a vapor saturado

Fonte: elaboração própria

Assim, de posse dos valores para os equipamentos principais, é possível fazer uma análise econômica prévia onde são levados em conta os preços dos energéticos e os investimentos 
mais significativos para substituição do aquecimento direto e calor de processo, juntamente com as equivalências estimadas entre os gases e a energia elétrica sob forma gráfica (Figuras 34 e 35) ou na Tabelas 41 e 42 respectivamente nos Apêndices C e D.

\subsection{Conclusões do capítulo 8}

Conforme proposto, o capítulo 8 apresentou a equivalência econômica entre a eletricidade e os gases combustíveis (GN e GLP), permitindo estudar a viabilidade da conversão nas mais diversas situações. Os gráficos traçados indicam claramente a existência de regiões onde a conversão de eletrotermia para GN e GLP é economicamente viável. Além disso, foram apresentados elementos que permitem a orientação do leitor quanto aos principais custos envolvidos nas conversões. 


\section{CONCLUSÕES E RECOMENDAÇÕES}

O trabalho desenvolvido por esta pesquisa permite concluir:

I. A conversão da eletrotermia para gases combustíveis no setor industrial brasileiro, considerando o aquecimento direto e o calor de processo, representa um potencial de redução de consumo total de energia elétrica em valor superior ao crescimento de um ano, levando-se em conta os números referentes aos últimos três anos.

II. A substituição da eletrotermia, total ou parcial, através da aplicação de gases combustíveis em processos industriais colabora para a redução de energia primária. $\mathrm{Na}$ hipótese da energia elétrica substituída reduzir a geração de termelétricas, as economias de energia primária correspondentes são muito significativas.

III. Existe disponibilidade atual e futura de gás natural para substituição da eletrotermia, embora esta ação esteja limitada geograficamente às áreas abastecidas pelas redes de distribuição existentes.

IV. Embora os modais de distribuição do GLP abranjam todos os municípios do território nacional, a substituição atual da eletrotermia exigiria um acréscimo das importações deste gás. Porém há previsão de equilíbrio entre a oferta e a demanda nacional entre 2016 e 2017, e de volumes excedentes de GLP a partir de 2018 que permitiriam complementar a oferta de gás natural, principalmente considerando os aspectos logístico e geográfico.

V. As conversões realizadas pelo autor sugerem que o aumento de produtividade pode ser obtido na maioria das conversões realizadas, sendo este aspecto um dos pontos considerados importantes pelas indústrias que experimentaram este processo, embora não tenha sido possível colher dados estatísticos que permitam generalizar os resultados.

VI. Os cálculos de equivalência energética realizados e os gráficos plotados, considerando os custos da energia elétrica e dos gases combustíveis, indicam a existência de muitas aplicações com possibilidades de conversão, com viabilidade econômica favorável às indústrias, considerando os custos dos energéticos e suas relações de eficiências. 
VII. A substituição da eletrotermia pode proporcionar às indústrias a possibilidade de renegociar a redução da demanda contratada com a concessionária de energia elétrica além de, quando aplicável, reduzir gastos com o consumo nos períodos de ponta e com o pagamento de multas por ultrapassagem da demanda contratada.

As recomendações desta tese são as seguintes:

I. Em sequência às conclusões desta tese, alguns temas poderiam ser pesquisados em decorrência da redução do consumo da eletrotermia como uma eventual postergação dos investimentos nos sistemas de geração, transmissão e distribuição da energia elétrica.

II. Outra recomendação seria a análise do impacto da substituição da eletrotermia na redução das emissões de gás carbônico e outros gases de efeito estufa.

III. Apesar de o Balanço de Energia Útil - BEU ser a melhor publicação disponível no Brasil, ainda apresenta limitações inerentes à escassez e à heterogeneidade das fontes de referência, como ocorreu nesta pesquisa no aquecimento direto no setor de ferrogusa e aço. No Anexo 1, segue a Instrução Normativa CNP / DIPLAN nº 01/84 e o Manual de Orientação da Pesquisa de Consumo de Energia que mostra a riqueza de informações solicitada no passado às empresas consumidoras de energia e que poderia servir de inspiração para a elaboração de uma planilha eletrônica, a ser enviada pelas empresas para o governo com uma periodicidade a ser estabelecida. Além de servir para os propósitos do planejamento energético governamental, os dados e a metodologia utilizados para a elaboração desta planilha seriam úteis para a própria empresa, contribuindo para os propósitos da conservação de energia e, também, para o processo de certificação da norma ISO-50001. 


\section{REFERÊNCIAS BIBLIOGRAFIAS}

ABIFA - Associação Brasileira de Fundição. Produção nacional de fundidos de 2004 a 2012. Informação passada por e-mail pelo Departamento de Estatísticas em 26/09/2013.

ABNT - Associação Brasileira de Normas Técnicas. NBR 12313: Sistemas de combustão, controle e segurança para a utilização de gases combustíveis em processos de baixa e alta temperatura, Rio de Janeiro, 2000.

ANEEL - Agência Nacional de Energia Elétrica. Resolução $\mathbf{N}^{\circ} 456$ de 29.11.2000, Brasília, 2000.

AHLBERG, K. AGA gas handbook, Lidingö, Sweden, 1985

ANP - Agência Nacional do Petróleo, Gás Natural e Biocombustíveis, Anuário Estatístico de 2012, 2012.

ANP - Agência Nacional do Petróleo, Gás Natural e Biocombustíveis, Resolução No 16 de 17.06.2008, publicada no D. O. U. em 18.06.2008.

ANP - Agência Nacional do Petróleo, Gás Natural e Biocombustíveis, Resolução ANP N 18 de 2.9.2004, publicada no D. O. U. em 6.9.2004, 2004.

ANP - Agência Nacional do Petróleo, Gás Natural e Biocombustíveis, Resolução ANP no 15 de 18.05.2005, publicada no D. O. U. em 20.05.2005.

BARTOK W, SAROFIM A., Fossil fuel combustion, a source book, John Wiley \& Sons, New York, USA, 1991.

BASSON, J., CURR, T.R. e GERICKE, W.A., South Africa's Ferro Alloys Industry Present Status and Future Outlook, International Ferro Alloy Congress, New Delhi, Índia, 2007.

BECERRA P., R., e COSTA, F.C., Dictamen Pericial Tecnico, Cosacol Hanover vs. Ecopetrol y Ecogas, Bogotá, Colômbia, 2001. 
BERMANN, C., Indústrias Eletrointensivas e Autoprodução: propostas para uma política energética de resgate do interesse público, IEE-USP, São Paulo, 2001.

BIZZO, W. et al., Safety issues for cleaning liquid and gaseous fuel for cooking in the scope of sustainable development, Energy for Sustainable Development, volume VIII, $\mathrm{n}^{\circ} 3$, setembro de 2004.

BRITISH PETROLEUM, Statistical Review of World Energy 2013, 2013

CARLYLE, T. Past and present, Chapman and Hall, London, 1843.

COSTA, F.C., O uso de ar propanado como backup de gás natural, Congresso da ABAR, 2009.

COSTA, F.C., Utilização de gases de baixo poder calorífico em processos de alta temperatura. Revista Cerâmica, nº 175, julho de 1984, p.15 a 22, São Paulo, 1984.

CURSINO DOS SANTOS, A.H., Eficiência energética e a contribuição dos gases combustíveis: análise de caso das políticas de avaliação de edificações, dissertação de mestrado, IEE - USP, 2011.

DENNY, L. et al., Handbook butane-propane gases, Chilton Company, Fourth Printing, Los Angeles, USA, 1962.

DEPARTMENT OF ENERGY AND DEPARTMENT OF INDUSTRY, Energy Audit Series No. 11, The Cement Industry, London, England, 1980.

DILliO, C. C. e NYE, E. P., Thermal engineering, International Textbook Company, Pennsylvania, USA, 1959.

DUBOIS, C. et al., Dictionnaire Encyclopédique Petit Larousse, $4^{\mathrm{a}}$ edição, Librairie Larousse, Paris, 1960.

ELETROBRÁS/PROCEL, Conservação de energia - eficiência energética de instalações e equipamentos, Editora da EFEI, Itajubá, Brasil, 2001. 
EPE, MME - Ministério de Minas e Energia, Plano Decenal de Expansão de Energia 2021, 2013.

FAGAN, B., The great warming: climate change and the rise and the fall of civilizations, First Edition, Bloomsbury Press, London, 2008.

FERRARO, M. C. e ALMEIDA, E. - Impacto da Estrutura de Financiamento sobre a Decisão de Investimento das Empresas de Distribuição de Gás Natural no Brasil, Boletim Infopetro, págs. 10 a 18, 2006.

FERREIRA, A. B. H. - Dicionário Aurélio Básico da Língua Portuguesa - Editora Nova Fronteira, Rio de Janeiro, 1988.

GLASSMAN, I., Combustion, terceira edição, Academic Press, USA, 1996.

GOLDEMBERG, J. e VILLANUEVA, L. D. Energia, meio ambiente \& desenvolvimento, Segunda edição, Editora da Universidade de São Paulo, São Paulo, 2003.

HENRIQUES JR, M. F. et al. - Manual de conservação de energia na indústria de cerâmica vermelha, MCTI / INT, Rio de Janeiro, Brasil, 1993.

HER MAJESTY'S STATIONERY OFFICE, The efficient use of fuel, A. Wheaton \& Co., Second Edition, Third Printing, London, England, 1969.

IBS, Instituto Brasileiro de Siderurgia, Anuário Estatístico da Siderurgia Brasileira 2005, Rio de Janeiro, 2005.

IEA, International Energy Agency, Key World Energy Statistics 2012.

LACKNER, M.; WINTER, F.; AGARWAL, K., (Org.). Handbook of Combustion, $3^{\circ}$ volume, Wiley-VCH, Weinheim, Alemanha, 2010.

MAGALHÃES, A. G., tese de doutorado "Caracterização e análise macro e micro estrutural de concretos fabricados com cimentos contendo escórias de alto-forno", UFMG, 2007.

MARQUES, I. N., Termodinâmica técnica, Editora Científica, Rio de Janeiro, Brasil, 1969. 
McCUllOUGH, S., HOCKADAY, S., JOHNSON, C. e BARCZA, N.A., Pre-reduction and smelting characteristics of Kazakhstan Ore Samples, The Twelfth International Ferroallows Congress, Helsinki, Finland, 2010.

MME, Ministério de Minas e Energia, Anuário Estatístico do Setor Metalúrgico 2013a.

MME, Ministério de Minas e Energia, Balanço Energético Nacional 2012, 2012.

MME, Ministério de Minas e Energia, Balanço Energético Nacional 2013, 2013 b.

MME - Ministério de Minas e Energia, Balanço de Energia Útil, 2005.

MME - Ministério de Minas e Energia, PORMIN, Beneficiamento de Minérios (2008).

MME - Ministério de Minas e Energia, Plano Nacional de Mineração 2030, Brasília, 2010, $178 \mathrm{p}$.

MME-SGM - Ministério de Minas e Energia, Secretaria de Geologia, Mineração e Transformação Mineral, Relatório Técnico 74 - Perfil de Louças Sanitárias e de Mesa, J. Mendo Consultoria, Brasília, 2009a.

MME-SGM - Ministério de Minas e Energia, Secretaria de Geologia, Mineração e Transformação Mineral, Relatório Técnico 71 - Refratários, J. Mendo Consultoria, Brasília, 2009b.

MME-SGM - Ministério de Minas e Energia, Secretaria de Geologia, Mineração e Transformação Mineral, Relatório Técnico 38 - Perfil do Calcário, J. Mendo Consultoria, Brasília, 2009c.

MME-SGM - Ministério de Minas e Energia, Secretaria de Geologia, Mineração e Transformação Mineral, Relatório Técnico 58 - Perfil do Aço, J. Mendo Consultoria, Brasília, 2009d.

MOREIRA, F. S., A integração refino petroquímica como alternativa para atendimento do crescente mercado de petroquímicos, Dissertação de Mestrado, Escola de Química da U.F.R.J, 149p., 2008.

NAKANO, H.; ARITA, K.; UCHIDA, S. New scrap preheating system for electric arc fuenace (UL-BA), Nippon Steel Technical Report No. 79, 1999. 
NOGUEIRA, L.A.H. e ROCHA, C.R. Programa de Formação em Energia, desenvolvido pelo CERNE - Centro de Excelência em Recursos Naturais e Energia para a Academia Ultragaz, 2005.

OLIVEIRA JR, S., Geração termelétrica e cogeração, notas de aula da disciplina PME2517, LETE - Laboratory of Environmental and Thermal Engineering, USP.

PELlEGRINI, L. F., COSTA, R. P., OLIVEIRA JR., S., Atribuição de custos em sistemas energéticos: a termoeconomia como base de cálculo, XXV Encontro Nacional de Eng. de Produção, Porto Alegre, Brasil, 2005.

PERRY, R.H.; GREEN, D.W. Handbook of chemical engineering. New York: McGrawHill, 1984.

PETROBRAS, Ficha de informação de segurança de produto químico - FISPQ, produto GLP, nº 0401, versão 1, 2011.

PIRES, A., Panorama e projeções dos mercados internacional e nacional de petróleo e gás natural, palestra proferida no Grupo Ultra, São Paulo - SP, em 14 de agosto de 2013.

PRITCHARD, R.,et al., Handbook of industrial gas utilization, Van Nostrand Reinhold Company, New York, 1977.

QUEIROZ, L.M.O., Estimação e análise das perdas técnicas na distribuição de energia elétrica, tese de doutorado, Universidade Estadual de Campinas, Faculdade de Engenharia Elétrica e de Computação, Campinas, 2010.

REED, R., North American combustion handbook, Volume I, Third Edition, Cleveland, Ohio, USA, 1986.

RENNIE, BRERETON-STILES e SINGH, Electrical energy management in the ferroalloy business, Tenth International Ferroalloy Congress, Cape Town, South Africa, 2004.

ROCHA, I., Máquina de estampar uma nova tecnologia gás natural, Seminário Tecnológico na FEBRATEX, Blumenau - SC, 2010.

SANTOS, E. M. et al., Gás natural: estratégias para uma energia nova no Brasil, Fapesp, Petrobras, Anablume Editora, São Paulo, Brasil, 2002. 
SCHMITT, R.J., Electric arc furnace scrap preheating, EPRI Center for Materials Production, 1997.

SEMELSBERGER, T. et al., Dimethyl ether (DME) as an alternative fuel, Journal of Power Sources No. 156, páginas 497 a 511, USA, 2006.

SENAI-FIEP, Recuperação química, III Seminário de Papel e Celulose, Telêmaco Borba PR, 2011.

SHVETS I. T. et al., Heat engineering, Mir Publishers, Moscow, Russia, 1980.

Software "Beräkning av Termisk Verkningsgrad" - AGA Aktiebolag - Sweden

Software "Vulcano 1.1" da Dynamis Mecânica Aplicada.

STRAPASSOM, Alexandre Betinardi. A energia térmica e o paradoxo da eficiência energética - desafios para um novo modelo de planejamento energético. 2004. 133f. Dissertação (Mestrado em Ciências) - Programa de pós-graduação em Energia da Universidade de São Paulo, São Paulo, 2004.

STRAPASSON, A. B.; FAGÁ, M. T. W., Energy efficiency and heat generation. An integrated analisys of the brazilian energy mix - International Energy Journal, Volume 8, Issue 3, September 2007.

TRINKS, W., Industrial furnaces, Volume I, Fifth Edition, John Wiley \& Sons London, 1961.

U. S. DEPARTMENT OF ENERGY, Modern shale gas development in the United States: a primer, 97 p., Estados Unidos da América, 2009.

VAN WYLEN, G. e SONNTAG, R., Fundamentos da termodinâmica clássica, Editora Edgard Blücher, São Paulo, Brasil, 1973.

VIEIRA, P. L. et al., Gás natural: benefícios ambientais do Estado da Bahia, Solisluna Design e Editora, Salvador, Bahia, 2005. 


\section{Websites:}

Site da ANEEL - Agência Nacional de Energia Elétrica - www.aneel.gov.br

Site da ANP - Agência Nacional do Petróleo, Gás e Biocombustíveis - www.anp.gov.br

Site da IDA - International DME Association - www.aboutdme.org, acesso em 02.09.2012.

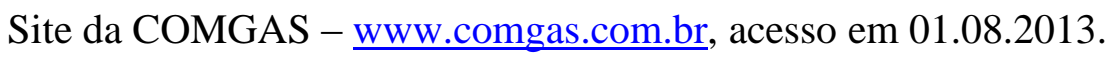

Site da ELETROBRÁS - www.eletrobras.com, acesso em 23.06.2012.

Site do IBGE - www.cnae.ibge.gov.br, acesso em 21.09.2013.

Site do INMETRO - Instituto Nacional de Metrologia, Qualidade e Tecnologia http://www.inmetro.gov.br/consumidor/tabelas.asp , acesso em 11.02.2013.

Site do INSTITUTO AÇO BRASIL

http://www.acobrasil.org.br/site/portugues/numeros/estatisticas.asp?par=201212, consulta em 22/09/2013.

Site da Krona - www.krona.srv.br

http://www.investidorpetrobras.com.br/pt/destaques-operacionais/custos-e-tributos/preco-devenda-do-gas-natural-no-city-gate-para-as-distribuidoras/preco-de-venda-do-gas-natural-nocity-gate-para-as-distribuidoras.htm, consulta em 27/07/2013).

Site do SINDIGÁS - www.sindigas.com.br , vários acessos. 
APÊNDICE A - Consumos específicos de eletricidade na produção de oxigênio

A utilização de queimadores com oxigênio em aquecimento direto, seja mediante o enriquecimento do ar de combustão ou a queima com elevados teores de oxigênio, em processos térmicos de médias e altas temperaturas, contribui para a redução do consumo de combustíveis e de energia elétrica. Por outro lado, não pode deixar de ser considerado o consumo de energia necessário para a produção do oxigênio, o qual depende basicamente da eletricidade para processos de compressão e refrigeração. Tal consumo de energia elétrica varia significativamente em função do tipo de planta, da pureza, da pressão e do estado físico do oxigênio.

De acordo com as informações prestadas pelo Eng. William Carlos Becker Jr., os consumos específicos de energia elétrica envolvidos na produção de oxigênio, no atual estado-da-arte, são os seguintes:

- Oxigênio no estado gasoso nas fornecido nas pressões de 3 a 5 bar g, produzidos on site apenas para aplicação em altos-fornos:

- gerado por VPSA, pureza de 92 a 95\%: $\quad 0,6 \mathrm{kWh} / \mathrm{Nm}^{3}$

- gerado por planta criogênica, pureza de 93 a $98 \%$ : $\quad 0,7 \mathrm{kWh} / \mathrm{Nm}^{3}$

- gerado por ASU, pureza de 99,7\%: $\quad 0,8 \mathrm{kWh} / \mathrm{Nm}^{3}$

- Oxigênio no estado gasoso nas pressões de 12 a 18 bar g, para aplicação em aciarias (FEA e altos-fornos):

- gerado por VPSA, pureza de 92 a $95 \%$ : $\quad 0,9 \mathrm{kWh} / \mathrm{Nm}^{3}$

- gerado por planta criogênica, pureza de 93 a 98\%: $\quad 1,0 \mathrm{kWh} / \mathrm{Nm}^{3}$

- Oxigênio no estado gasoso nas pressões de 12 a 18 bar g, para aplicação em FEA e convertedores:

- gerado por ASU, pureza de 99,7\%: $1,1 \mathrm{kWh} / \mathrm{Nm}^{3}$

- Oxigênio no estado gasoso na pressão de 32 bar g, para aplicação em FEA e convertedores através de buffers (pulmão em pressão mais elevada para compensar a necessidade dos picos de demanda nas citadas aplicações, que se contrapõe com o processo contínuo de produção de oxigênio):

- gerado por VPSA, pureza de 92 a 95\%: $\quad 1,0 \mathrm{kWh} / \mathrm{Nm}^{3}$

- gerado por planta criogênica, pureza de 93 a 98\%: $\quad 1,1 \mathrm{kWh} / \mathrm{Nm}^{3}$

- gerado por ASU, pureza de 99,7\%: $\quad 1,2 \mathrm{kWh} / \mathrm{Nm}^{3}$ 
- Oxigênio no estado líquido para transporte criogênico e uso geral

- gerado por ASU, pureza de 99,7\%:

$1,8 \mathrm{kWh} / \mathrm{Nm}^{3}$ 
APÊNDICE B - Configurações de chama

Este apêndice tem por objetivo informar e alertar o leitor com respeito aos diversos tipos de configurações de chama possíveis de serem adotados na conversão de eletrotermia para gases combustíveis.

A seleção do tipo de chama é o segundo parâmetro mais importante a ser determinado juntamente com a seleção dos queimadores e seu controle de potência, de acordo com seu posicionamento no equipamento térmico. A forma da chama deve proporcionar uma melhor transmissão de calor para a carga sem, contudo, superaquecê-la a ponto de danificá-la ou provocar gradientes de temperatura não admissíveis, como também não prejudicar a estrutura do equipamento.

A Figura 41 apresenta o tipo mais comum de chama, encontrada na maioria dos bocais dos queimadores, também conhecida como pena ou pluma devido à sua forma e por apresentar um perfil ligeiramente assimétrico e ascendente devido ao fenômeno da convecção. $\mathrm{O}$ International Flame Research Foundation - IFRF a denomina como chama de jato.

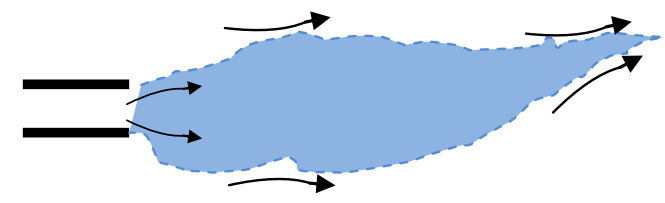

Figura 41 - Tipo de chama convencional

Ref.: Internacional Flame Research Foundation - IFRF apud Reed (1997, p.4)

Na Figura 42, a denominação headpin deve-se à semelhança de sua forma com um pino de boliche, recebendo a classificação Type I do IFRF. É uma chama mais curta que a convencional considerando-se igual potência, proporcionando algum grau de recirculação interna, o que favorece a redução das emissões de frações não queimadas como monóxido de carbono e hidrocarbonetos.

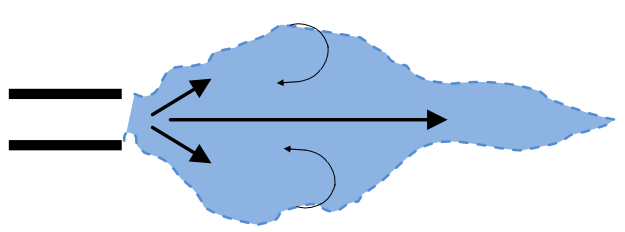

Figura 42 - Tipo de chama headpin

Ref.: Internacional Flame Research Foundation - IFRF apud Reed (1997, p.4) 
A Figura 43 trata-se de uma chama curta e com formato aproximado de uma esfera, devido a uma intensa recirculação interna, sendo classificada como Type II pelo IFRF. Este tipo de chama aplica-se quando necessário evitar o contato da chama com a carga ou com a estrutura interna da fornalha, favorecendo ainda a redução das emissões de frações não queimadas devido à citada recirculação.

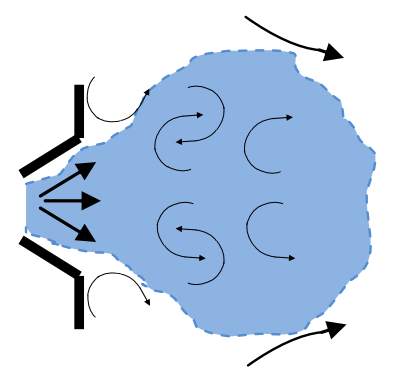

Figura 43 - Tipo de chama esférica

Ref.: Internacional Flame Research Foundation - IFRF apud Reed (1997, p.4)

A Figura 44 representa uma chama cônica semi-sólida, devido a uma zona de pressão axial negativa na base do cone, a qual gera um fluxo de gases na temperatura média da fornalha fluindo na região axial do cone da chama e no sentido do queimador, abrindo um volume na base deste cone. Este tipo de chama favorece a recirculação da atmosfera da câmara de combustão, proporcionando uma melhor homogeneização da temperatura.

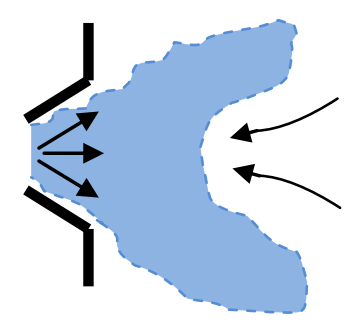

Figura 44 - Tipo de chama cônica

Ref.: Reed (1997, p.4)

O tipo de chama plana, apresentado na Figura 45, é adequado quando se necessita transferir calor para uma superfície paralela ao plano da chama e/ou evitar atingir a carga do equipamento, o que a torna muito adequada à substituição de bancos de resistências elétricas instaladas em superfícies planas, como paredes e tetos de fornos. Apesar de a chama de gás ser pouco radiante, a proximidade da chama promove o aquecimento da parede de refratário 
adjacente aumentando sua transmissão de calor por radiação deste material cerâmico para a carga, de acordo com a Lei de Stefan-Boltzmann.

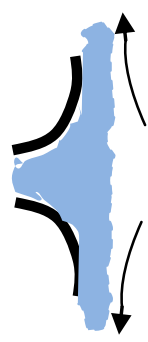

Figura 45 - Tipo de chama plana

Ref.: $\quad$ Reed (1997, p.4)

O tipo de chama longa, luminosa e flácida, mostrada na Figura 46, é pouco empregada devido a se tratar de uma combustão incompleta, mas apresenta uma parcela de transferência de calor por radiação mais intensa. No cômputo geral, esta prática não é vantajosa, exceto se alguma combinação de suas características, como tranferência de calor, formato longo da chama e atmosfera redutora seja indispensável a algum processo em particular. É denominada pelo IFRF como type zero.

Figura 46 - Chama longa, luminosa e flácida

Ref.: Internacional Flame Research Foundation - IFRF apud Reed (1997, p.4)

A chama apresentada na Figura 47 é muito semelhante à chama anterior, razão pela qual recebe a mesma denominação do IFRF (type zero). Porém é mais rígida (ou menos flácida) devido a um maior aporte de ar de combustão, embora ainda não haja ainda comburente suficiente para a combustão completa.

Figura 47 - Chama longa, luminosa e firme

Ref.: Internacional Flame Research Foundation - IFRF apud Reed (1997, p.4) 
As chamas de alta velocidade iniciam sua combustão na câmara de pré-mistura, sendo acelerada no bocal convergente de saída, caracterizando-se por elevada turbulência no interior da chama, o que favorece a intimidade da mistura gás-ar, e intensa recirculação da atmosfera no ambiente onde a chama de estabelece, favorecendo a transmissão de calor por convecção forçada, conforme mostra a Figura 48. Essa turbulência promove a tendência desta chama ser mais curta que a de queimadores de baixa velocidade considerando igual potência e, também, de diluir sua temperatura no interior da câmara de combustão num percurso mais curto ao longo do eixo da chama. Trata-se de uma chama com aspecto extremamente rígido e bem definido.

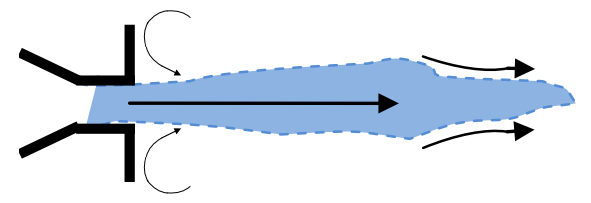

Figura 48 - Chama de alta velocidade

Ref.: Reed (1997, p.4)

As chamas de alta velocidade também são características da queima de gases combustíveis com comburentes de alto teor de oxigênio, onde as modalidades de pré-mistura e de mistura na saída do bocal podem ser praticadas. Essas elevadas velocidades encontram-se também presentes nos queimadores de acetileno e de hidrogênio, devido às características desses gases combustíveis e por essa razão dispositivos especiais contra retrocesso de chama devem sempre ser instalados. Em algumas aplicações especiais, o autor praticou o enriquecimento de gases de baixa velocidade de chama como o GLP e o GN com hidrogênio para elevar a velocidade da chama, possibilitando a otimização de processos como acabamento e polimento térmico de peças de vidro e de cristal. 
APÊNDICE C - Equivalência GN - energia elétrica

O Apêndice $\mathrm{C}$ tem por objetivo apresentar os valores para 1 MWh na conversão de energia elétrica para gás natural, a partir da relação entre os rendimentos entre estes dois vetores energéticos e considerando, ainda, os preços do GN.

Tabela 41 - Equivalência GN - energia elétrica

\begin{tabular}{|c|c|c|c|c|c|c|c|c|c|c|}
\hline \multicolumn{11}{|c|}{ EQUIVALÊNCIA GN - ENERGIA ELÉTRICA } \\
\hline \multicolumn{11}{|c|}{ Valor de $1 \mathrm{MWh}$ convertido pelo GN (R\$) } \\
\hline Relação $\eta \mathrm{EE} / \eta \mathrm{GN}$ & 0,8 & 0,9 & 1,0 & 1,1 & 1,2 & 1,3 & 1,4 & 1,5 & 1,6 & 1,7 \\
\hline \multicolumn{11}{|l|}{ Preço do GN $\left(\mathrm{R} \$ / \mathrm{m}^{3}\right)$} \\
\hline 2,60 & 203,28 & 228,69 & 254,10 & 279,51 & 304,92 & 330,33 & 355,74 & 381,15 & 406,56 & 431,97 \\
\hline 2,40 & 187,64 & 211,10 & 234,55 & 258,01 & 281,46 & 304,92 & 328,37 & 351,83 & 375,28 & 398,74 \\
\hline 2,20 & 172,00 & 193,51 & 215,01 & 236,51 & 258,01 & 279,51 & 301,01 & 322,51 & 344,01 & 365,51 \\
\hline 2,00 & 156,37 & 175,91 & 195,46 & 215,01 & 234,55 & 254,10 & 273,64 & 293,19 & 312,74 & 332,28 \\
\hline 1,80 & 140,73 & 158,32 & 175,91 & 193,51 & 211,10 & 228,69 & 246,28 & 263,87 & 281,46 & 299,05 \\
\hline 1,60 & 125,09 & 140,73 & 156,37 & 172,00 & 187,64 & 203,28 & 218,92 & 234,55 & 250,19 & 265,83 \\
\hline 1,40 & 109,46 & 123,14 & 136,82 & 150,50 & 164,19 & 177,87 & 191,55 & 205,23 & 218,92 & 232,60 \\
\hline 1,20 & 93,82 & 105,55 & 117,28 & 129,00 & 140,73 & 152,46 & 164,19 & 175,91 & 187,64 & 199,37 \\
\hline 1,00 & 78,18 & 87,96 & 97,73 & 107,50 & 117,28 & 127,05 & 136,82 & 146,60 & 156,37 & 166,14 \\
\hline \multicolumn{11}{|c|}{ EQUIVALÊNCIA GN - ENERGIA ELÉTRICA } \\
\hline \multicolumn{11}{|c|}{ Valor de 1 MWh convertido pelo GN (R\$) } \\
\hline Relação $\eta \mathrm{EE} / \eta \mathrm{GN}$ & 1,8 & 1,9 & 2,0 & 2,1 & 2,2 & 2,3 & 2,4 & 2,5 & 2,6 & 2,7 \\
\hline \multicolumn{11}{|l|}{ Preço do $\mathrm{GN}\left(\mathrm{R} \$ / \mathrm{m}^{3}\right)$} \\
\hline 2,60 & 457,38 & 482,79 & 508,20 & 533,61 & 559,02 & 584,43 & 609,84 & 635,25 & 660,65 & 686,06 \\
\hline 2,40 & 422,19 & 445,65 & 469,10 & 492,56 & 516,01 & 539,47 & 562,92 & 586,38 & 609,84 & 633,29 \\
\hline 2,20 & 387,01 & 408,51 & 430,01 & 451,51 & 473,01 & 494,51 & 516,01 & 537,52 & 559,02 & 580,52 \\
\hline 2,00 & 351,83 & 371,37 & 390,92 & 410,47 & 430,01 & 449,56 & 469,10 & 488,65 & 508,20 & 527,74 \\
\hline 1,80 & 316,65 & 334,24 & 351,83 & 369,42 & 387,01 & 404,60 & 422,19 & 439,79 & 457,38 & 474,97 \\
\hline 1,60 & 281,46 & 297,10 & 312,74 & 328,37 & 344,01 & 359,65 & 375,28 & 390,92 & 406,56 & 422,19 \\
\hline 1,40 & 246,28 & 259,96 & 273,64 & 287,33 & 301,01 & 314,69 & 328,37 & 342,06 & 355,74 & 369,42 \\
\hline 1,20 & 211,10 & 222,82 & 234,55 & 246,28 & 258,01 & 269,73 & 281,46 & 293,19 & 304,92 & 316,65 \\
\hline 1,00 & 175,91 & 185,69 & 195,46 & 205,23 & 215,01 & 224,78 & 234,55 & 244,33 & 254,10 & 263,87 \\
\hline \multicolumn{11}{|c|}{ EQUIVALÊNCIA GN - ENERGIA ELÉTRICA } \\
\hline \multicolumn{11}{|c|}{ Valor de 1 MWh convertido pelo GN (R\$) } \\
\hline Relação $\eta \mathrm{EE} / \eta \mathrm{GN}$ & 2,8 & 2,9 & 3,0 & 3,1 & 3,2 & 3,3 & 3,4 & 3 & 3,6 & 3,7 \\
\hline \multicolumn{11}{|l|}{ Preço do GN $\left(\mathrm{R} \$ / \mathrm{m}^{3}\right)$} \\
\hline 2,60 & 711,47 & 736,88 & 762,29 & 787,70 & 813,11 & 838,52 & 863,93 & 889,34 & 914,75 & 940,16 \\
\hline 2,40 & 656,75 & 680,20 & 703,66 & 727,11 & 750,57 & 774,02 & 797,48 & 820,93 & 844,39 & 867,84 \\
\hline 2,20 & 602,02 & 623,52 & 645,02 & 666,52 & 688,02 & 709,52 & 731,02 & 752,52 & 774,02 & 795,52 \\
\hline 2,00 & 547,29 & 566,83 & 586,38 & 605,93 & 625,47 & 645,02 & 664,56 & 684,11 & 703,66 & 723,20 \\
\hline 1,80 & 492,56 & 510,15 & 527,74 & 545,33 & 562,92 & 580,52 & 598,11 & 615,70 & 633,29 & 650,88 \\
\hline 1,60 & 437,83 & 453,47 & 469,10 & 484,74 & 500,38 & 516,01 & 531,65 & 547,29 & 562,92 & 578,56 \\
\hline 1,40 & 383,10 & 396,78 & 410,47 & 424,15 & 437,83 & 451,51 & 465,19 & 478,88 & 492,56 & 506,24 \\
\hline 1,20 & 328,37 & 340,10 & 351,83 & 363,56 & 375,28 & 387,01 & 398,74 & 410,47 & 422,19 & 433,92 \\
\hline 1,00 & 273,64 & 283,42 & 293,19 & 302,96 & 312,74 & 322,51 & 332,28 & 342,06 & 351,83 & 361,60 \\
\hline
\end{tabular}


APÊNDICE D - Equivalência GLP - energia elétrica

O Apêndice B tem por objetivo apresentar os valores para $1 \mathrm{MWh}$ na conversão de energia elétrica para GLP, a partir da relação entre os rendimentos entre estes dois vetores energéticos e considerando, ainda, os preços do GLP.

Tabela 42 - Equivalência GLP - energia elétrica

\begin{tabular}{|c|c|c|c|c|c|c|c|c|c|c|}
\hline \multicolumn{11}{|c|}{ EQUIVALÊNCIA GLP - ENERGIA ELÉTRICA } \\
\hline \multicolumn{11}{|c|}{ Valor de 1 MWh convertido pelo GLP (R\$) } \\
\hline Relação $\eta \mathrm{EE} / \eta$ GLP & 0,8 & 0,9 & 1,0 & 1,1 & 1,2 & 1,3 & 1,4 & 1,5 & 1,6 & 1,7 \\
\hline \multicolumn{11}{|l|}{ Preço do GLP $(\mathrm{R} \$ / \mathrm{kg})$} \\
\hline 3,40 & 210,75 & 237,09 & 263,43 & 289,78 & 316,12 & 342,46 & 368,80 & 395,15 & 421,49 & 447,83 \\
\hline 3,20 & 198,35 & 223,14 & 247,94 & 272,73 & 297,52 & 322,32 & 347,11 & 371,90 & 396,70 & 421,49 \\
\hline 3,00 & 185,95 & 209,20 & 232,44 & 255,68 & 278,93 & 302,17 & 325,42 & 348,66 & 371,90 & 395,15 \\
\hline 2,80 & 173,56 & 195,25 & 216,94 & 238,64 & 260,33 & 282,03 & 303,72 & 325,42 & 347,11 & 368,80 \\
\hline 2,60 & 161,16 & 181,30 & 201,45 & 221,59 & 241,74 & 261,88 & 282,03 & 302,17 & 322,32 & 342,46 \\
\hline 2,40 & 148,76 & 167,36 & 185,95 & 204,55 & 223,14 & 241,74 & 260,33 & 278,93 & 297,52 & 316,12 \\
\hline 2,20 & 136,36 & 153,41 & 170,46 & 187,50 & 204,55 & 221,59 & 238,64 & 255,68 & 272,73 & 289,78 \\
\hline 2,00 & 123,97 & 139,46 & 154,96 & 170,46 & 185,95 & 201,45 & 216,94 & 232,44 & 247,94 & 263,43 \\
\hline 1,80 & 111,57 & 125,52 & 139,46 & 153,41 & 167,36 & 181,30 & 195,25 & 209,20 & 223,14 & 237,09 \\
\hline \multicolumn{11}{|c|}{ EQUIVALÊNCIA GLP - ENERGIA ELÉTRICA } \\
\hline \multicolumn{11}{|c|}{ Valor de 1 MWh convertido pelo GLP (R\$) } \\
\hline Relação $\eta \mathrm{EE} / \eta$ GLP & 1,8 & 1,9 & 2,0 & 2,1 & 2,2 & 2,3 & 2,4 & 2,5 & 2,6 & 2,7 \\
\hline \multicolumn{11}{|l|}{ Preço do GLP (R $\$ / k g)$} \\
\hline 3,40 & 474,18 & 500,52 & 526,86 & 553,21 & 579,55 & 605,89 & 632,24 & 658,58 & 684,92 & 711,27 \\
\hline 3,20 & 446,28 & 471,08 & 495,87 & 520,67 & 545,46 & 570,25 & 595,05 & 619,84 & 644,63 & 669,43 \\
\hline 3,00 & 418,39 & 441,64 & 464,88 & 488,12 & 511,37 & 534,61 & 557,86 & 581,10 & 604,34 & 627,59 \\
\hline 2,80 & 390,50 & 412,19 & 433,89 & 455,58 & 477,28 & 498,97 & 520,67 & 542,36 & 564,05 & 585,75 \\
\hline 2,60 & 362,61 & 382,75 & 402,90 & 423,04 & 443,19 & 463,33 & 483,48 & 503,62 & 523,76 & 543,91 \\
\hline 2,40 & 334,71 & 353,31 & 371,90 & 390,50 & 409,09 & 427,69 & 446,28 & 464,88 & 483,48 & 502,07 \\
\hline 2,20 & 306,82 & 323,87 & 340,91 & 357,96 & 375,00 & 392,05 & 409,09 & 426,14 & 443,19 & 460,23 \\
\hline 2,00 & 278,93 & 294,42 & 309,92 & 325,42 & 340,91 & 356,41 & 371,90 & 387,40 & 402,90 & 418,39 \\
\hline 1,80 & 251,04 & 264,98 & 278,93 & 292,87 & 306,82 & 320,77 & 334,71 & 348,66 & 362,61 & 376,55 \\
\hline \multicolumn{11}{|c|}{ EQUIVALÊNCIA GLP - ENERGIA ELÉTRICA } \\
\hline \multicolumn{11}{|c|}{ Valor de 1 MWh convertido pelo GLP (R\$) } \\
\hline Relação $\eta \mathrm{EE} / \eta$ GLP & 2,8 & 2,9 & 3,0 & 3,1 & 3,2 & 3,3 & 3,4 & 3,5 & 3,6 & 3,7 \\
\hline \multicolumn{11}{|l|}{ Preço do GLP $\left(\mathrm{R} \$ / \mathrm{m}^{3}\right)$} \\
\hline 3,40 & 737,61 & 763,95 & 790,30 & 816,64 & 842,98 & 869,33 & 895,67 & 922,01 & 948,36 & 974,70 \\
\hline 3,20 & 694,22 & 719,01 & 743,81 & 768,60 & 793,40 & 818,19 & 842,98 & 867,78 & 892,57 & 917,36 \\
\hline 3,00 & 650,83 & 674,08 & 697,32 & 720,56 & 743,81 & 767,05 & 790,30 & 813,54 & 836,78 & 860,03 \\
\hline 2,80 & 607,44 & 629,14 & 650,83 & 672,53 & 694,22 & 715,92 & 737,61 & 759,30 & 781,00 & 802,69 \\
\hline 2,60 & 564,05 & 584,20 & 604,34 & 624,49 & 644,63 & 664,78 & 684,92 & 705,07 & 725,21 & 745,36 \\
\hline 2,40 & 520,67 & 539,26 & 557,86 & 576,45 & 595,05 & 613,64 & 632,24 & 650,83 & 669,43 & 688,02 \\
\hline 2,20 & 477,28 & 494,32 & 511,37 & 528,41 & 545,46 & 562,50 & 579,55 & 596,60 & 613,64 & 630,69 \\
\hline 2,00 & 433,89 & 449,38 & 464,88 & 480,38 & 495,87 & 511,37 & 526,86 & 542,36 & 557,86 & 573,35 \\
\hline 1,80 & 390,50 & 404,45 & 418,39 & 432,34 & 446,28 & 460,23 & 474,18 & 488,12 & 502,07 & 516,02 \\
\hline
\end{tabular}


ANEXO A

INSTRUÇÃO NORMATIVA CNP / DIPLAN Nº 01/84 PESQUISA DE CONSUMO DE ENERGIA 


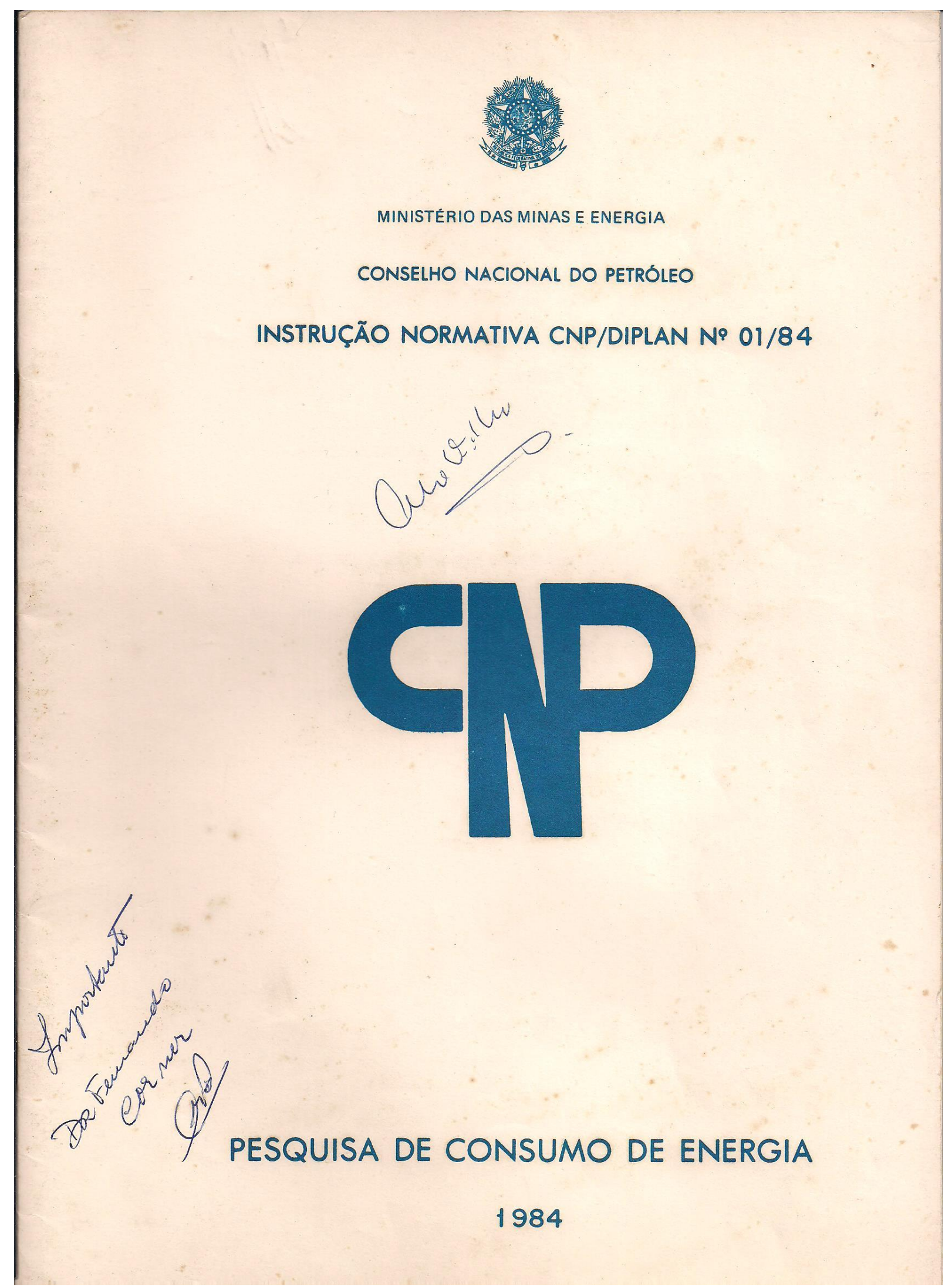


INDICE

1 - APRESENTAÇÃO . . . . . . . . . . . . . . . . .

II - COMPOSIÇÃO dO QUESTIONARIO ...................

III - INSTRUÇOES PARA PREENCHIMENTO ................ 3

IV - APENDICE 1 - TABELA DOS CÓDIGOS DE ATIVIDADES INDUSTRIAIS ........................

$\checkmark$ - APENDICE 2 - TABELA DE ENERGÉTICOS COM SEUS RESPECTIVOS CÓDIGOS E PODERES CALORIFICOS SUPERIORES ............................ 10 


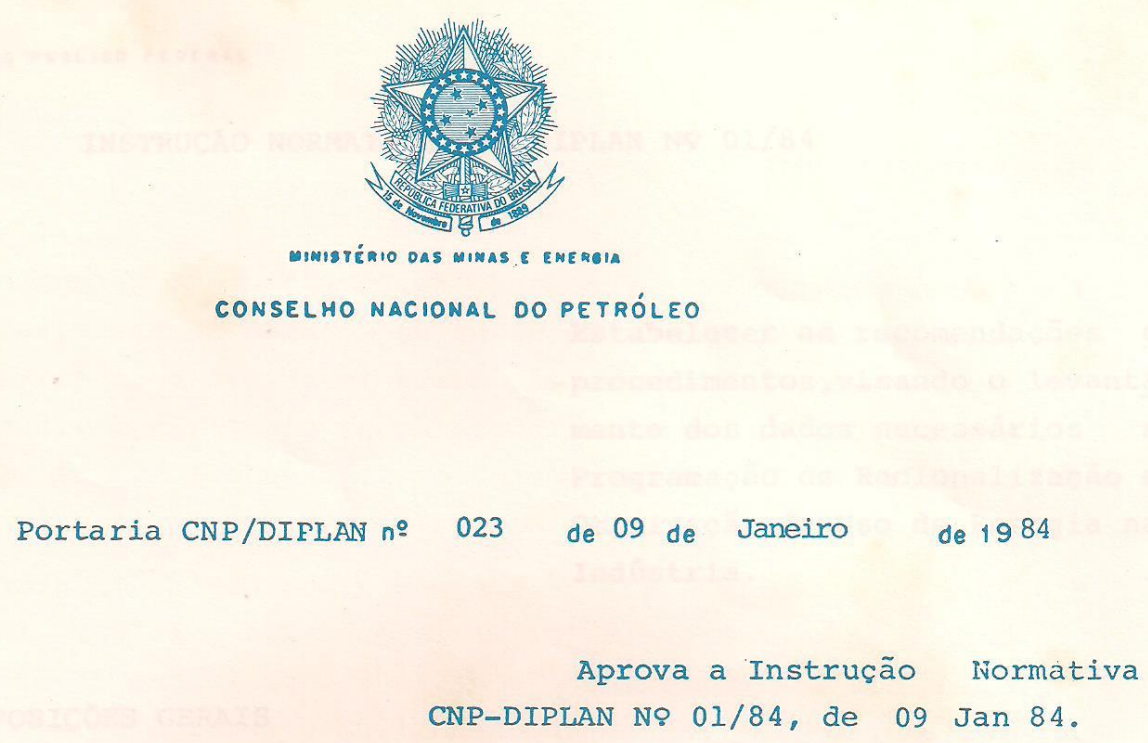

\section{O Presidente do Conselho Nacional}

do Petróleo, no uso das atribuições que the confere o Art. 65, item VIII, do Regimento Interno, aprovado pela Portaria Ministerial n: 235, de 17 de fevereiro de 1977, do Senhor Ministro das Minas e Energia, resolve:

Art. 1: - Aprovar a Instrução Normativa CNP-DIPIAN NO 01/84, integrante desta Portaria, que estabelece as recomendações e procedimentos, visando o levantamento dos dados necessários a Programação de Racionalização e Otimização do Uso de Energia na Indústria, no Ano de 1984 .

Art. 2: - Esta Portaria entra em vigor na data de sua publicação, revogadas as disposições em contrário.

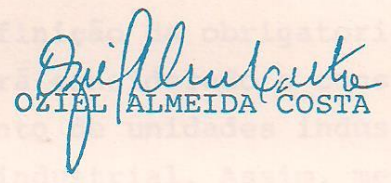


SERVIGO PUQLICO FEDERAL

INSTRUÇÃO NORMATIVA CNP/DIPLAN NO 01/84

Estabelecer as recomendaçōes e procedimentos, visando o levanta mento dos dados necessários a Programação de Racionalização e Otimização do Uso de Energia na Indústria.

DISPOSIÇÕES GERAIS

1 - A presente instrução estabelece as normas e procedimentos que permitam um efetivo levantamento da utilização da energia nas indústrias, visando a obtenção da racionalidade do uso de energéticos, derivados do petróleo ou não, sem prejuízo da pro dução industrial, encarando o problema de forma global.

2 - Deverão apresentar o levantamento todos os usuários de energi a que tenham consumido o correspondente a mais de 500 t/ano de óleo combustível, representado por derivados de petróleo ou fontes alternativas de energia, ou seja, que tenham consumido acima de $5200 \mathrm{Gcal} / \mathrm{ano}$ de quaisquer fontes de energia., durante o ano de 1979, ou nos anos subsequentes, e os que em fa se final de instalação, prevejam consumir aqueles valores em 1984.

2.1 - Para efeito da definição da obrigatoriedade da apresentação dos dados, será considerado o consumo global de energéticos do conjunto de unidades industriais pertencentes a um mesmo grupo industrial. Assim, mesmo que individualmente uma unidade industrial consuma menos que o equivalente a 500 t/ano de óleo residual do petróleo, qualquer que seja a fonte energética, deverá preencher as planiIhas.

3 - Como o presente trabalho visa estudos energéticos, não estão incluidos nesta instrução os que os usem como matéria-prima.

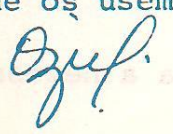


4 - o levantamento será realizado de acordo com o disposto no Manual de Orientação da Pesquisa de Consumo de Energia-1984, aneso a esta. A distribuicão desta instrução será feita atravẻs da ECT. As empresas remeterão as planilhas devidamente pre enchidas ao CNP, diretamente, ou através dos Escritórios de Repre sentação do $\mathrm{CNP}_{\gamma}$ obedecendo os prazos fixados no item 6 .

5 - Para as indústrias que já possuem a sua comissão Interna de Conservação de Energia (CICE) reconhecida pelo CNP, a coleta de dados, o preenchimento e envio das planilhas deverão ser feitos por ela, sob a responsabilidade técnica de seu responsável, designado na constituição do organismo. Se, entretanto, não houver ainda CICE organizada, o preenchimento deverá ser feito por Engenheiro ou Químico registrado no CREA ou CRQ.

6 - As empresas deverão enviar as planilhas devidamente preenchidas até 30.04 .84 , de forma que sejam entregues em Brasília antes de 15.05 .84

6.1 - No caso de um Grupo Industrial a entrega dos dados das unidades pertencentes a ele, deverá ser feita pela CCE do Grupo, que será responsável pela exatidão das informações.

DAS DISTRIBUIDORAS E DOS T.R.R.

7 - As Distribuidoras e os T.R.R. receberão exemplares desta instrução a fim de fazerem a entrega aos seus novos clientes do ano de 1983 que se enquadrem no item 2 das Disposições Gerais da presente instrução.

Posteriormente deverão fornecer ao CNP (DIPLAN) relação dos mencionados clientes especificando:

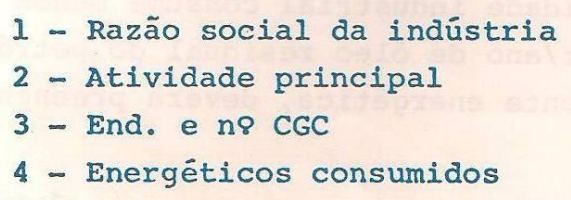

DAS INDUSTRIAS

8 - o CNP enfatiza a necessidade de criação das CICEs a fim de

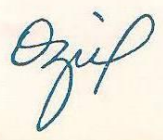


SERVIGO PÚBLICO PEDERAL

melhor regularização do relacionamento CNP/indústria para o trato dos problemas energéticos.

9 - De posse do Manual de Orientação 1984 - Pesquisa de Consumo de Energia, através das CICEs, ou Engenheiro ou Quỉmico registrado no CREA ou $\mathrm{CRQ}$, as indústrias procederão ao preenchimento correto das planilhas, seguindo as instruções contị das no Manual de Orientação.

10 - Executado o levantamento, providenciarão seu envio ao CNP.

11 - Dentro da programação organizada para as CICEs, deverão as indústrias efetuar estudos visando determinar o mais rigoroso balanço energético em cada setor do sistema industrial e implantar as medidas estabelecidas para a otimização do uso da energia.

12 - A responsabilidade pelas informações caberá à Direção da Empresa e à CICE, que responderão, perante o CNP, por sua exatidão.

13 - Quando julgado conveniente pelo CNP, serão realizadas inspe cões para acompanhar e verificar as atividades da CICE. Se os dados forem julgados insuficientes serão exigidos novas infor mações, de tal forma que haja eficiência nos levantamentos.

DAS COMISSÓES INTERNAS DE CONSERVACÃO DE ENERGIA

14 - Deverão operar de acordo com o que preceituam as portarias CNP/DIPLAN/NOS 139/82 e 437/82, publicadas nos D.O.U de 26 Abr.82 e 20 Dez 82, respectivamente.

$$
\text { Brasília, } 09 \text { de janẹiro de } 1984
$$

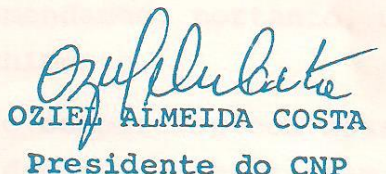


seavigo píbico peogab

INSTRUÇÃO NORMATIVA CNP/DIPLAN NQ 01/84

MANUAL DE ORIENTAÇÃO - PESQUISA DE CONSUMO DE ENERGIA - 1984

I - APRESENTACূA

o presente manual foi elaborado com a finalidade de permitir às indústrias o controle dos consumos de energia e a determi nação da evolução da eficiência do seu uso ao longo do tempo. Destina-se a auxiliar os encarregados dos controles de consumo de energia no preenchimento do questionário apresentado.

E importante ressaltar que este questionário visa o aperfeiçoamento dos controles de eficiência no uso da energia. o CNP considera que os dados solicitados nos anos anteriores, ou sejam, as condições de operação dos sistemas de vapor(caldeiras), flui dos térmicos, fornos, fornalhas e secadores, no que se refere à combustão, recuperação de calor, isolamento térmico, etc, devam continuar a ser controlados no âmbito de cada indústria, de forma con tínua e sistemática.

- CNP considera essencial a criação de uma Comissão Interna de Conservação de Energia (CICE), no âmbito de cada unidade industrial, encarregada de todos os controles aqui mencionados. A eventual falta de capacitação técnica dentro de uma determinada in dústria justifica a contratação de técnicos especializados, de com provada competência, a fim de apoiar a CICE naqueles controles e nos projetos que redundem em conservação de energia ou substituição de derivados de petróleo.

A nova apresentação dada ao questionário exigirá maior culdado no seu preenchimento: recomendamos, portanto, uma leitura cuidadosa das instruções de preenchimento.

Os dados fornecidos serão comparados com nossos arquivos históricos e, caso o CNP encontre dados que apresentem dúvidas,têc 
nicos poderão ser destacados para uma visita às suas instalações para esclarecer essas dúvidas. Lembre-se que respostas distorcidas poderão levar à adoção de políticas distorcidas.

A coleta das informações permitirā ao CNP o intercâmbio de informações com as indústrias e associaçōes técnicas, buscando a orientação mútua na condução dos programas de conservação de e-

nergia. Caso a sua indústria possua um controle de consumo mais de talhado, solicitamos a colaboração no sentido do envio de sugestões que permitam o aprimoramento do presente manual.

II - COMPOSIÇÃO DO QUESTIONÁRIO

\section{Formulário Geral}

Este formulário deve ser preenchido por toda indūstria enquadrada na presente instrução normativa. Caso um grupo indústri al ou empresa possua mais de uma unidade industrial, deverá apresentar um Formulário Geral para cada unidade, acompanhado dos res pectivos anexos.

Anexo 01 - Seções com controle de consumo de energéticos

Neste anexo devem ser relacionadas as seçōes com contro le de consumo de energéticos.

Anexo 02 - Consumo total de energéticos por tipo de utilização em 1983

Neste anexo devem ser informados os energéticos consumi dos, por tipo de utilização, durante 1983.

$\underline{\text { Anexo } 03}$ - Produções e consumos de energéticos do ano-base e do a no de 1983

Neste anexo devem ser informados as produções e os consumos do ano-base e do ano de 1983 para cada seção relacionada no Anexo 01. Note que devem ser preenchidos um Anexo 03 para cada se cão relacionada no Anexo 01. Caso não exista controle de produção e consumo por seção, deve ser preenchido um ünico Anexo 03 conten do os dados totais dos anos em referência, assinalando o item 01Seção-Global. 
. 3.

senvigo fúcLico bedEAL

Anexo 04 - Incidência do Custo de Energia sobre a produção e o faturamento.

Este anexo, contém informações sobre as despesas com os diversos energéticos e a incidēncia sobre a Produção e o Faturamen to no período de 1979 a 1983.

Anexo 05 - Informações sobre geração de vapor d'água/caldeiras.

contém informações referentes às caracteristicas das cal deiras geradoras de vapor em cada unidade industrial.

Anexo 06 - Informações sobre fluidos térmicos ou água quente/caldeiras.

Contém informações referentes às características das cal deiras usadas para aquecimento de fluidos térmicos ou água quente existentes em cada unidade industrial.

Anexo 07 - Informações sobre fornalhas.

Entende-se por fornalha, o equipamento que tem a finalidade de aquecer fluidos de processo cujo objetivo seja não suprir a área de utilidade, e que circulam no interior de serpentinas de àquecimento, usando o potencial térmico dos energéticos como agente. Este anexo contèm informações sobre fornalhas.

Anexo 08 - Informações sobre fornos.

Entende-se por forno, o equipamento de processo que tem por finalidade o aquecimento de materiais por meio direto ou indireto, usando o potencial térmico dos energéticos como agente de aquecimento e que não possam ser enquadrados nas definições de fornalha e secadores. Este anexo contém informações sobre fornos.

Anexo 09 - Informações sobre secadores/estufas.

Contém, este anexo, informaçöes sobre secadores/estufas e sua utilização. Entende-se por secador todo equipamento onde o material tratado é aquecido com o objetivo de evaporar seus componentes voláteis.

Anexo 10 - Cálculo do Desempenho Energético em Relação ao Ano-Base (vide Anexo 03 para o preenchimento)e observações. 


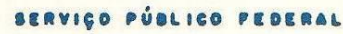

Neste anexo deve ser calculado o desempenho energético em relação ao Ano-Base de cada seção relacionada no Anexo 01, ou global caso não haja controle de consumo individualizado para cada seção. Para o preenchimento e cálculo deste anexo é imprescindivel consultar o Anexo 03 que contēm todas informações necessárias para o correto preenchimento deste anexo.

Neste anexo, também, devem ser feitas todas observaçōes, se necessárias, referentes ao preenchimento de cada anexo. Para melhor entendimento solicita-se a identificação do anexo a que se refere a observação.

Anexo 11 - Projetos de conservação de energia e substituição de derivados de petróleo.

Anexo, no qual, deve-se fazer uma especificação e descrição suscinta dos projetos de conservação de energia e substitu ição de derivados de petrôleo.

III - INSTRUÇÕES PARA PREENCHIMENTO

FORMULARTIO GERAL

Quadro 01 - Para uso do processamento

Identificação

Quadro 02 - ne do CGC

Indicar o no do CGC da unidade industrial

Quadro 03 - Razão Social

Indicar a razão social da unidade industrial, colocan do uma letra em cada espaço. O nome deverá ser abreviado de modó que não prejudique a fácil identificação da empresa.

Abaixo apresentamos algumas abreviaçãoes mais comuns:

NOME

Agropecuária

Artefatos

Brasileira
ABREVIAÇAO

Agrop

Artef

Bras 
.5 .

\footnotetext{
SEMVICO PUELICO PEOERAL
}

$\begin{array}{ll}\text { Cerāmica } & \text { Ceram } \\ \text { Comércio } & \text { Com } \\ \text { Companhia } & \text { Cia } \\ \text { Cooperativa } & \text { Coop } \\ \text { Cotonifício } & \text { Coton } \\ \text { Empresa } & \text { Emp } \\ \text { Expor cação } & \text { Exp } \\ \text { Fábrica } & \text { Fab } \\ \text { Frigorífico } & \text { Frig } \\ \text { Fundição } & \text { Fund } \\ \text { Importação } & \text { Imp } \\ \text { Indústria } & \text { Ind } \\ \text { Industrial } & \text { Indl } \\ \text { Indústrias } & \text { Inds } \\ \text { Laminação } & \text { Lamin } \\ \text { Metalürgica } & \text { Metal } \\ \text { Refinaria } & \text { Ref } \\ \text { Siderurgia } & \text { Sider } \\ \text { Sociedade } & \text { Soc } \\ \text { Sociedade anônima } & \text { SA }\end{array}$

Lembramos que os mesmos NÃO deverão ser seguidos de sinais gráficos, como:

Ind. Com.

$S / A$.

INBRABA - Ind. Bras. de Barcos

Quadro 04 - Endereço da Unidade Industrial

Indicar o endereço da unidade citando rua, estrada, etc, e respectivo número. Notar que este endereço refere-se à unidade produtora e não ao escritório ou sede. O endereço deverá ser abreviado, como segue abaixo:

$\begin{array}{ll}\text { Alameda } & \text { Al } \\ \text { Avenida } & \text { Av } \\ \text { Conjunto } & \text { Cj } \\ \text { Estrada } & \text { Est } \\ \text { Fazenda } & \text { Fz }\end{array}$




$\begin{array}{ll}\text { Praça } & \text { PC } \\ \text { Rodovia } & \text { Rod } \\ \text { Rua } & \text { R } \\ \text { Travessa } & \text { TV }\end{array}$

Quadro 05 - CEP - Uso do processamento - município - UF.

CEP - Indicar o Código de Endereçamento postal relativo ao endereco da unidade industrial.

Uso do processamento - não deverá ser preenchido.

Municipio - indicar o nome do município onde está localizada a uni dade industrial.

UF - indicar a sigla da UNIDADE DA FEDERAÇÃO onde está localizada a unidade industrial.

Quadro 06 - Endereço para correspondência (Sede ou Escritório)

Caso a unidade industrial possua sua sede ou escritório localizado em endereço diferente, indicá-lo neste quadro.

Quadro 07 - CEP - Uso do processamento - Muniこipio - UF

CEP - indicar o Código de Endereçamento Postal onde está localizado a sede ou escritório.

Uso do processamento - Não deverá ser preenchido.

Municippio - indicar o nome do município onde está localizada a sede ou escritório.

UF - indicar a sigla da Unidade da Federação onde está localizada a sede ou escritório.

Informaçōes sobre Comissão Interna de Conservação de Energia-CICE

Quadro 08 - Só deve preencher este quadro a empresa que já tiver Comissão Interna de Conservação de Energia(CICE), reconnhecida pelo CNP. Deve-se informar o nome do coordenador ou responsável pela CICE, o nümero do registro do certificado de reconhecimento expedido pelo CNP, o telefone do coordenador ou responsável pela CICE, a assinatura, bem como a data de reconhecimento da CICE. 


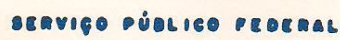

Quadro 09 - Responsável pelo preenchimento.

Caso a empresa não possua CICE reconhecida pelo CNP, - preenchimento deverá ser feito por engenheiro ou químico regís trado no CREA ou CRQ, que se responsabilizará pelo preenchimento e assinatura do presente questionärio.

Quadro 10 - Setor Industrial - cōdigo de atividade

Este quadro destina-se a especificar o principal setor industrial, em que se enquadra a unidade industrial através dos códigos do Apêndice n̊ 1, na ordem de importância.

Observacão importante: Note que os códigos a serem indicados referem-se aos produtos comercializados pela empresa. Caso, durante o processo produtivo, uma unidade industrial fabrique um outro tipo de produto que seja utilizado no seu processo produtivo e não comercializado não deverá considerar esse produto intermediário para efeito de indicação dos códigos de atividades.

Anexo 01 - Seções com controle de consumo energéticos.

Neste anexo devem ser relacionadas todas as seções com controle de consumo de energéticos no período 1979 a 1983: indicando na frente o respectivo código de atividade em que se enqua dra. (vide apêndice 1 ).

Para cada seção com controle de consumo de energéticos, indicada neste anexo, deverá ser feito um anexo 03. No entanto, caso a empresa não possua controle de consumo individual por seção, deverá relacionar as seções existentes na empresa e confeccionar um único anexo 03 referente à produção global; para tanto deverá indicar no item 01 do Anexo 03 - Seção-Global.

Caso o número de seções ultrapasse a quantidade de itens deste anexo, deverão ser tiradas tantas cópias quantas forem necessărias: devendo, no entanto, ser dada a continuidade nu meracão sequencial dos itens da folha anterior.

Aneso 02 - Consumo Total de Energéticos por Tipo de Utilização em 1983. 
Itens 01 à 22

Neste anexo devem ser relacionados todos os energéticos e quantidades consumidas durante o ano de 1983, diferenciando o tipo de equipamento consumidor como indicado. Observe que cada energético possui um código, conforme relacionado no Apêndi ce 2.

Casc a empresa consuma um energético que não esteja re lacionado no Apēndice 2, deverá indicá-1o deixando o espaço para - cōdigo em branco. No entanto, no Anexo 10 deverá ser feita toda a especificação do energético, como por exemplo: PCS, unidade de medida, teor de umidade etc.

Anexo 03 - Produções e Consumos de Energéticos do Ano-Base e do Ano de 1983.

Neste anexo devem ser informadas as produções e os con sumos de energéticos do Ano-Base e do ano 1983. Para cada seção relacionada no Anexo 01, que tenha controle de produção e consumo individualizado, deve-se preencher um Anexo 03; ou seja, devem ser preenchidos tantos Anexos 03 quantas forem as seções, com controle de produção e consumo, relacionados no Anexo 01. Caso a empresa nã்o tenha controle de produção e consumo individualizado por seção, deverá preencher um único Anexo 03 informando a produção global e o consumo total de todos energéticos relativos aos anos 1979 e 1983.

Item 01 - Caso a indústria não possua controle de consumo de secão individualizado, colocar em frente o campo SEÇÃO-GLOBAL o número 0,0 . Caso a indústria possua controle por seção, colocar en frente o campo SEÇÃO-No o número correspondente ao iN: da seção indicada no Aneso 01.

Item 02 - Produção - Nada a preencher.

Item 03 e 04 - Ano-Base

Assinalar com um $X$ ○ item 03 se o Ano-Base for 1979, ou assinalar o item 04 se o Ano-Base for outro diferente de 1979 ,nes te caso deve-se indicar o ano no campo reservado à frente.Isso no caso de não ter havido atividades em 1979. 
Abaixo deste campo, em todo o Anexo, devem conter os dados referentes ao Ano-Base.

Item 05 - Ano de 1983

Abaixo deste campo, em todo o Anexo, devem conter os dados de 1983.

Item 06 - código da unidade de medida da produção

Neste campo deve ser colocado o código de medida da produção, conforme a Tabela I.

\begin{tabular}{|c|c|c|c|}
\hline 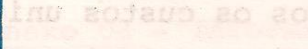 & UNIDADE & ABREVIATUEA & CÓDIGO \\
\hline MASSA & $\begin{array}{l}\text { QUILO } \\
\text { TONELADA }\end{array}$ & $\begin{array}{l}\mathrm{Kg} \\
\mathrm{t} \\
\end{array}$ & $\begin{array}{r}41 \\
42 \\
\end{array}$ \\
\hline VOLUME & $\begin{array}{l}\text { LITRO } \\
\text { HECTOLITRO } \\
\text { METRO CUBICO } \\
\text { MIL METROS CUBICOS }\end{array}$ & $\begin{array}{l}1 \\
\mathrm{hl} \\
\mathrm{m}^{3} \\
10^{3} \mathrm{~m}^{3} \\
\end{array}$ & $\begin{array}{l}51 \\
52 \\
53 \\
54\end{array}$ \\
\hline COMPRIMENTO & $\begin{array}{l}\text { METRO } \\
\text { MIL METROS }\end{array}$ & $\begin{array}{l}\mathrm{m} \\
10^{3} \cdot \mathrm{m}\end{array}$ & $\begin{array}{r}61 \\
62 \\
\end{array}$ \\
\hline AREA & $\begin{array}{l}\text { METRO QUADRADO } \\
\text { MIL METROS QUADRADOS }\end{array}$ & $\begin{array}{l}\mathrm{m}^{2} \\
10^{3} \mathrm{~m}^{2}\end{array}$ & $\begin{array}{l}71 \\
72 \\
\end{array}$ \\
\hline UNIDADES & $\begin{array}{l}\text { UNIDADE } \\
\text { MIL UNIDADES } \\
\text { PARES } \\
\text { MILHARES DE PARES }\end{array}$ & $\begin{array}{l}\text { unid } \\
10^{3} \text { unid } \\
\mathrm{pr} \\
10^{3} \mathrm{pr}\end{array}$ & $\begin{array}{l}81 \\
82 \\
83 \\
84 \\
\end{array}$ \\
\hline OUTROS & $\begin{array}{l}\text { ESPECIFICAR A UNIDADE NO A- } \\
\text { NEXO 10-OBSERVACOOES }\end{array}$ & & 90 \\
\hline
\end{tabular}

Item 07 - Fator de Conversão em Tonelada

Caso a unidade de medida de produção não seja tonelada (considerada unidade padrão, para efeito de comparação), indicar - fator de conversão.a ser aplicado para se obter o equivalente em $t$. 


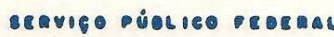

Item 08 - Indicar neste campo a producão do Ano-Base

Item 09 - Indicar neste campo a produção de 1983.

Itens 10 a 42 - Nestes itens devem ser informados os energéticos e as quantidades consumidas durante 1979 e durante 1983. Note que sob a coluna consumo devem ser colocadas as quantidades nas unidades comerciais, e sob a coluna ENERGIA-Gcal, as quantidades em Gcal, para tanto consulte o Apêndice 2 e, com o poder calorifico superior do energético, calcule a quantidade de energia consumida. Anexo 04 - Incidência do Custo da Energia sobre a Produção e o Faturamento

Itens 01 a 15 - Nestes itens devem ser informados os energéticos consumidos no periodo de 1979 a 1983 , com os seus respectivos cus tos.

Itens 16 a 18 - Nestes itens devem ser informados os custos unitâ rios da energia. Para o cálculo divida o custo da energia pela quantidade consumida no respectivo ano.

Itens 19 a 24 - Informar conforme solicitado no anexo.

Anexo 05 - Informações sobre Geraç̃o de Vapor Dágua/Caldeiras

Informar neste anexo as caracteristicas das caldeiras existentes na unidade industrial. Devem ser informados, para cada caldeira, o tipo, pressão de trabalho, temperatura de saída do vapor, producão média de vapor, total de horas de operaç̃o em 1982 os côdigos dos energéticos consumidos em cada caldeira (ví de o código no Apêndice 2). Caso a quantidade de caldeiras ultrapasse a capacidade do Anexo, tirar tantas cópias quantas forem necessårı́s.

Anexo 06 - Informacōes sobre Fluidos Tẻrmicos ou Agua Quente/CaI deiras

Informar neste anexo as características das caldeiras existentes na unidade industrial. Devem ser informados, para cada caldeira, o tipo, pressão de trabalho, temperatura de saida do Iluido, capacidade nominal, produção média horária, total de ho ras de operacão em 1983 e os cỏdigos dos energéticos consumidos em cada caldeira. (vide o cỏdigo no Apêndice 2) 
Caso a quantidade de caldeiras ultrapasse a capacidade do Anexo, tirar tantas cópias quantas forem necessárias.

Anexo 07 - Informaçöes sobre fornalhas

Informar neste anexo as características das fornalhas existentes na unidade industrial. Devem ser informados, para cada fornalha, o tipo, fluido processado, temperatura de saída do flui do, capacidade nominal, a produção média horária de calor ou seja a quantidade de calor gerada pela fornalha, horas de operação em 1983 e os códigos dos energéticos utilizados nas respectivas fornalhas (vide o código no apêndice 2). Caso a quantidade de fornalhasultrapasse a capacidade do Anexo, tirar tantas cópias quantas forem necessárias.

Anexo 08 - Informações sobre fornos

Informar neste anexo as características dos fornos existentes na unidade industrial, especificando os seguintes dados:

- tipo do forno - Utilizara seguinte codificação:

1 - Fornos continuos

1A-Túnel

1B-Canal, Bicanal,Tricanal, ftc

1C-Esteira

1D-Empurrador

1E-Barra caminhante("Walking Beam")

IF-Soleira Rotativa

1G-Rotativo

1H-Vertical

II-A rolos

IJ-Tanque

1K-Cadinho

IL-Basculante

1M-Reverbero

IN-Reversível

10-Multiandar

IP-Campânula
2 - Fornos intermitentes

2A-Cadinho

2B-Carro

2C-Poço

2D-Garrafão

2E-Sino

2F-Câmara

2G-Caixa

2H-Pànela

2I-Reverbero

2J-Tanque

2K-Soleira Móvel

2L-Soleira Fixa

2M-Túnel

2N-Reversivel

20-Rotativo

2P-Ustulador 
Caso a quantidade de caldeiras ultrapasse a capacidade do Anexo, tirar tantas cópias quantas forem necessárias.

Anexo 07 - Informaçöes sobre fornalhas

Informar neste anexo as caracteristicas das fornalhas existentes na unidade industrial. Devem ser informados, para cada fornalha, o tipo, fluido processado, temperatura de saída do flui do, capacidade nominal, a producão média horária de calor ou seja a quantidade de calor gerada pela fornalha, horas de operação em 1983 e os códigos dos energéticos utilizados nas respectivas fornalhas (vide o código no apêndice 2). Caso a quantidade de fornaIhasultrapasse a capacidade do Anexo, tirar tantas cópias quantas forem necessárias.

Anexo 08 - Informações sobre fornos

Informar neste anexo as caracteristicas dos fornos existentes na unidade industrial, especificando os seguintes dados:

- tipo do forno - Utilizara seguinte codificação:

1 - Fornos continuos

1A-Túne]

1B-Canal, Bicanal,Tricanal ,tc

IC-Esteira

ID-Empurrador

lE-Barra caminhante ("Walking Beam")

IF-Soleira Rotativa

IG-Rotativo

1H-Vertical

II-A rolos

IJ-Tanque

IK-Cadinho

II-Basculante

IM-Reverbero

IN-Reversivel

10-Multiandar

lP-Campānula
2 - Fornos intermitentes

2A-Cadinho

2B-Carro

2C-Poço

2D-Garrafão

2E-Sino

2F-Câmara

2G-Caixa

2H-Pànela

2I-Reverbero

2J-Tanque

2K-Soleira Móvel

2L-Soleira Fixa

2M-Túnel

2N-Reversivel

20-Rotativo

2P-Ustulador 


\section{0-Catenāria}

1R-Cuba

1s-Cubilô

1T-Gaveta

lU-Soleira Fixa

IV-Soleira Móvel

1X-Cämara

1Y-Incinerador

IW-Leito Fluidizado

12-Garrafão

3A-Estacionário c/rosca

3B-Sinterização

3C-Indução

3D-Arco Trifásico

3E-Condução

3F-Resistēncia Elétrica

3G-Outros(especificar no Anexo 10)

- Material processado no forno

Exemplo: minério, aço, ferro fundido, metais não ferrosos, vidro, cimento, cerâmica, etc.

- Finalidade de tratamento efetuado

Exemplo: tratamento térmico, sinterização, fusão, refino, calcị nação, etc

- Temperatura Máxima

- Produção média do forno - em $t / h$ para fornos contínuos e em $t / c \underline{i}$ clo para fornos intermitentes

- Produção máxima

- Horas de operação em 1983

- Códigos dos energéticos utilizados nos respectivos fornos. (vide Apêndice 2)

Anexo 09 - Informações sobre Secadores/Estufas
2S-Campānula

2V-Barranco

2X-LD

2Y-Indução

2W̉-Arco Trifásico

-Cuba Eletrolitica

A-Resistência elétrica

AB-Outros (especificar no Anexo 10)
2Q-Alto Forno

2R-Cubilô 


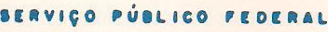

Informar neste anexo as caracteristicas dos secadores/ estufas existentes na unidade industrial, especificando os seguin tes dados:

- o tipo de secador/estufa-utilizar a seguinte codificação:

1 - contínuo

1A-Rotativo

1B-Pneumático ("Flash-Dryer")

IC-Atomizador ("Spray-Dryer")

ID-Britador

1E-Bandejas

IF-Leito fluidizado

lG-Canal

1H-Câmara

1I-Túnel

IJ-Esteira

IK-Vertical

1L-Rosca Transportadora

IM-Tambor

IN-Radiador

10-Outros (especificar no Anexo 10)

- Material processado - Incicar o material processado

- Fluido evaporado - mencionar o fluido ou então se é efetuada a cura sem que haja vaporização de qualquer fluido.

- Agente de secagem - indicar o agente de secagem/cura-Utilizar a seguinte codificação.

A - AR

B - Gases de combustão

C - AR + gases de combustão

D - Aquecimento sem que haja contato ou mistura do agente com o produto

- Temperatura de entrada do agente-No caso de estufas tipo câmara indicar a temperatura de operação.

- Umidade do material na base úmida
2 - Intermitente

2B-Leito Fluidizado

2C-Leito Fixo 
BERVIGO DÚLICO De OEALL

OBS: Umidade na base úmida é definida como:

$\emptyset=\frac{M_{\text {água ou solvente }}}{\begin{array}{l}\text { Material isento de } \\ \text { água ou solvente }\end{array}+{ }^{M} \text { água ou solvente }}$

- Produção - indicar a produção média de material seco em $t / h$ ou $t / c i c l o$, conforme o caso

- Horas de operação em 1983

- Códigos dos energéticos consumidos nos respectivos secadores/estu fas (vide Apēndice 2)

Anexo 10 - Cálculo do Desempenho Energético em Relação ao Ano-Base e Observações

Neste anexo deve ser calculado o desempentio energético. em relação ao Ano-Base. Todos os dados necessários a estes cálculos estão no Anexo 03 .

Note que para cada Anexo 03 deve ser preenchido um Ane xo 10, ou seja, deve ser calculado o desempenho energético para cada seção relacionada no Anexo 01.

Item 01 - Colocar 00 em frente o campo SEÇÃO GLOBAL se a empresa não possui controle de produção e consumo por seção. Colocar o no referente a cada seção relacionada no Anexo 01 em frente 0 . Campo SEÇÃO-NO para as empresas que possuem controle de produção e consumo por seção.

Item 02 - Consumo específico derivado petróleo - 1983

Item 03 - Consumo específico total - 1983

Item 04 - Fator de produção

Produção de 1983 dividido pela produção do Ano-Base

Item 05 - Equivalente energético do Ano-Base-Derivado Petróleo

Item 06 - Equivalente energético do Ano-Base-Total

Item 07 - Desempenho energético - Derivado do petróleo

Item 08 - Desempenho energético - Total 
.15.

SEMVIGO PÚRICO BEOEAL

Item 09 - Observações

Fazer observações especificando o Anexo e o item a que se refere

Anexo 11 - Projetos de Conservação de Energia e Substituição de De rivados de Petróleo

Especificar e descrever a situação dos Projetos de conservação de Energia e Substituição de Derivados do Petróleo.

Observação: Apesar das atividades de fabricação de cimento, vidro e cerāmica estarem englobadas nas de minerais não metá licos, serão consideradas, para efeito deste levantamento, separadamente, dada a importância delas no contexto inaustrial brasileiro. 